\title{
Environmental Assessment in Support of Proposed Voluntary Energy Conservation Standard for New Residential Buildings
}
D. L. Hadley
S. J. Marsh
G. B. Parker
J. M. Roop
J. W. Callaway
Z. T. Taylor

June 1989

Prepared for the U.S. Department of Energy under Contract DE-AC06-76RLO 1830

Pacific Northwest Laboratory

Operated for the U.S. Department of Energy

by Battelle Memorial Institute 


\title{
DISCLAIMER
}

This program was prepared as an account of work sponsored by an agency of the United States Government. Neither the United States Government nor any agency thereof, nor Battelle Memorial Institute, nor any of their employees, makes any warranty, express or implied, or assumes any legal liability or responsibility for the accuracy, completeness, or usefulness of any information, apparatus, product, or process disclosed, or represents that its use would not infringe privately owned rights. Reference herein to any specific commerical product, process, or service by trade name, trademark, manufacturer, or otherwise, does not necessarily constitute or imply its endorsement, recommendation, or favoring by the United States Government or any agency thereof, or Battelle Memorial Institute. The views and opinions of authors expressed herein do not necessarily state or reflect those of the United States Government or any agency thereof.

\section{PACIFIC NORTHWEST LABORATORY operated by \\ BATTELLE MEMORIAL INSTITUTE \\ for the \\ UNITED STATES DEPARTMENT OF ENERGY \\ under Contract DE-ACO6-76RLO 1830}

\author{
Printed in the United States of America \\ Available from \\ National Technical Information Service \\ United States Department of Commerce \\ 5285 Port Royal Road \\ Springfield, Virginia 22161 \\ NTIS Price Codes \\ Microfiche A01 \\ Printed Copy
}

$\begin{array}{cc}\text { Pages } & \begin{array}{c}\text { Price } \\ \text { Codes } \\ 001-025\end{array} \\ 026-050 & \text { A02 } \\ 051-075 & \text { A03 } \\ 076-100 & \text { A04 } \\ 101-125 & \text { A05 } \\ 126-150 & \text { A06 } \\ 151-175 & \text { A07 } \\ 176-200 & \text { A08 } \\ 201-225 & \text { A09 } \\ 226-250 & \text { A10 } \\ 251-275 & \text { A11 } \\ 276-300 & \text { A12 } \\ & \text { A13 }\end{array}$


33679000563736

PNL-6735

UC $-95 d$

ENVIRONIENTAL ASSESSITENT

IN SUPPORT OF

PROPOSED VOLUNTARY ENERGY

CONSERVATIOIN STANDARD FOR

NEW RESIOENTIAL BUILDINGS

$\begin{array}{ll}\text { D. L. Hadley } & \text { S. J. llarsh } \\ \text { C. B. Parker } & \text { J. If. Roop } \\ \text { J. H. Callaway } & \text { Z. T. Taylor }\end{array}$

June 1989

Prepared for

the U.S. Departinent of Energy

under Contract DE-AC06-76RLO 1830

Pacific florthwest Laboratory

Richland, llashington $9935 ?$ 


\section{SUIIIARY}

Under Title III of the Energy Conservation and Production Act (the Act) (Pub. L. 94-385), as amended, the Secretary of Energy is responsible for developing performance standards for all new residential and comiercial buildings. For the federal sector, the standards set mandatory performance levels for the design of federal buildings. For the private sector, the standards are voluntary and serve as guidelines, providing technical information and examples of energy-efficient design practices. The DOE has developed two standards for residential construction. The federal standard (FEDRES) contains mandatory requirements for new construction by federal agencies; the second standard (VOLRES) provides a voluntary guide for private sector construction. This Environmental Assessment (EA) addresses only the latter voluntary standard.

The U.S. Department of Energy (DOE) prepared this EA to explore the possible environmental effects of the proposed voluntary standard on residential buildings constructed for the private sector. This assessment was done as part of DoE's responsibility under the National Environnental Policy Act of 1969, as amended (Pub. L. 91-190, January 1, 1970), and the inplementing regulations of the Council on Environerental Quality (CEQ) (40 CFR Parts 150(1-1508). Pecause the proposed standard is voluntary in nature and is intended to serve as a guideline for the private sector, the DOE prepared an EA to address inpacts if the voluntary standard is adopted as a riandatory code by state or local jurisdictions. The latter assuription forms the basis for the impacts assessed in this report.

The scope of this assessment is limited to the possible environmental effects on the private sector of the proposed voluntary standard. The econoric and socioecononic imacts of the proposed voluntary residential standard have been analyzed in a separate docunent (Econonic Analysis--Proposed Interin Voluntary [nergy Conservation Standard for llew Residential bui1digus, DOE 1088) and are surritarized in this EA.

The En exarines the consequences of the proposed voluntary standard, i.e., the impacts which are attributable to differences between the design of the baseline residertial units and units designod to the voluntary standard. This 
assessment emphasizes the possible alterations to the indoor air quality of a residence, and by reference, the estimated effects on the life-cycle cost and energy use of new residential buildings.

This EA indicates that the impact of the voluntary standard on building habitability, the outdoor environment, the economy, and institutions would not be significant. Specific results are summarized below.

HABITABILITY

In this assessment, habitability is expressed in terms of changes in various indoor air pollutant concentrations and the conconitant health and safety impacts to occupants as a result of building design changes required by the proposed voluntary standard. No significant effects on building habitability were found.

Various pollutants are released continuously or internittently within residential buildings. An indoor air quality computation model that uses specific pollution emission values (release rates) for selected materials was usec to calculate pollutant concentration levels in the case-study residences, basec on baseline conditions and on the proposed standard. Incremental pollutant concentrations were calculated for particulate matter, carbon monoxide (CO), carbon dioxide $\left(\mathrm{CO}_{2}\right)$, nitrogen dioxide $\left(\mathrm{NO}_{2}\right)$, radon and formaldehyde. The potential impact on indoor air quality of chemical compounds and microorganisms was assessed qualitatively because the quantitative detail necessary for simulation modeling is not available.

Particulate Matter

Implementation of the proposed voluntary standard is expected to have no effect on the level of particulate matter in residences. Carbon Honoxide

Currently, estimated indoor concentrations of carbon monoxide (CO) from cooking and smoking are well below levels associated with health risk. The proposed voluntary standard would have no effect on co concentrations. 


\section{Carbon Dioxide}

Residential units designed under the proposed voluntary standard are expected to maintain low concentration leveis of carbon dioxide $\left(\mathrm{CO}_{2}\right)$. The health risk from indoor $\mathrm{CO}_{2}$ concentrations would not change.

Hitrogen Dioxide

Release of nitrogen dioxide $\left(\mathrm{NO}_{2}\right)$ in residential indoor environcients is small. The simulated concentrations of $\mathrm{HO}_{2}$ for the proposed voluntary standard residential units are the same as for baseline residential units.

Radon

Estimated values for indoor air concentrations of radon in residential units, would be the same for the baseline and the proposed voluntary standard residential units.

Formaldehyde

The proposed voluntary standard reduces the level of formaldenyde in some locations and increases concentrations at other locations. Although the ragnitude of the change is sriall, increases could affect certain individuals who have a very low threshold of sensitivity to formaldehyde. A worst case scenario (niniblum allowable infiltration rate) results in larger iricreases of this pollutant, but resulting concentrations are still below levels that would cause health effects in most individuals.

Cherical Compounds

i large nurber of chemical pollutants have been identified in inciour residential air. llany of these cherlical conpounds are either odorous, irritants, or suspected carcinogens. However, the proposed voluntary standard is not expected to measurably increase or decrease health risks due to cherical pollutants in residential indoor air.

iiicroorganisms

Under certain conditions, microorganisas can become indoor air pollutants with a notential health risk. The most severe probleins resulting such 
pollutants occur when organisris grow on a damp surface or on stagnant water collected on horizontal surfaces. The proposed voluntary standard is not expected to affect existing levels of microorganisiss in residential structures.

OUTDOOR ENVIRONIIENTAL IMPACTS

On a national basis, there would be a net improvenent in outdoor environmental quality from reduced fossil fuel usage. The voluntary standard reduces estimated insulation level in some locations that were studied, and increases them in other sites. As a result, the net inpact on insulation production is not 1 ikely to affect the general magnitude of airborne pollutarits fror? its production.

ECONOMIC IMPACTS

The economic analysis of the proposed voluntary standard for new residential buildings concludes that there are no significant adverse effects to society from adopting the VOLPES standard. The voluntary standard will result in a positive net flow of benefits from energy savings that rore than offsets higher capital construction and other costs, when compared to current practice. This conclusion was reached by comparing the life-cycle costs of prototypes constructed to current practice or codes and those of units that neet the proposed voluntary standard.

The national net (economic) effect of the voluntary standard, assuming its inrediate and full penetration, ranges from nearly $\$ 930$ million in net benefits. for 1988 construction to $\$ 1,035$ million for 1992 construction. This effect is based on the net present value of energy savings and capital costs using a tirle frame of 15 years. For construction in 1992, the year with the largest net effect, the capital costs of compliance to the voluntary standard are \$1.? bil.. lion. The net present value of energy savings accrued over the 15-year tirle frame for butidings constructed in 1992 is nearly $\$ 2.2$ billion. The difference: represents a net benefit of $\$ 1.0$ bilion.

Because the standard is voluntary, the net benefits were also calculated assuming that penetration of the proposed standard was staged over a five-yenr 
period (1988-1992). In this scenario, full penetration of the voluntary standard does not occur until 1992. The national net effect of the voluntary standard ranges from nearly $\$ 186$ million in net benefit for construction in 1988 to $\$ 1,035$ million for construction in 1992 .

The voluntary standard also creates a net benefit for individual regions. Assuming full penetration of the voluntary standard, the Northeast receives the greatest annual benefit until 1993, when the net benefits in the South overtake those of the Northeast. The net benefit to the lortheast increases from $\$ 336$ million for 1988 construction to $\$ 384$ billion in 1992 , after which the net benefit drops steadily until the 2001-2005 construction period, when it reaches $\$ 220$ million. The net benefit to the lest is the stallest of all regional benefits over the study period. Changes in the relative share of net costs and benefits are attributable to corecasted trends in tne regional distribution of new housing.

The total ecoromic imact of the voluntary standare, as measured in the gross value of industry output and employrent, were estimated using the U.S. Input-output table. For the vurposes of tris analysis, the effects of the energy savings have been assumed to occur in the year of construction, when in reality, the energy savings occur over a fifteen-year time period. In 1992 , the construction year with the yreatest indirect inpacts, the conbined effect, of changes in output results in a net loss of approximately $\$ 2.5$ billion in output due to construction. This net decrease in output results fron a $\$ 2.2$ billion increase in output resulting from increased capilal expenditures for construction and the $\$ 4.7$ billion decrease in output resulting frol: lower energy expenditures. Even when all of the output effects of changes in energy costs over fifteen years are assumed to occur in the initial year of construction, the output change represents only 0.05 percent of the total 1..S. Gross liational product. This is not considered significant.

The net loss of 10,900 jobs associated with 1991 construction represents the greatest total effect on employment. This figure is composed of an increase of neariy $31, \$ 00$ jobs due to increased construction costs and a loss 
of over 42,600 jobs from decreased energy expenditures. This estinlate of employment effects, probabiy an overestimate, represents less than 0.01 percent of total U. S. employment, a figure not considered significant.

IIPACTS ON INSTITUTIONS

The proposed voluntary standard is intended to be a guideline for construction of residential buildings in the private sector. Because it is not a binding standard, there are no institutional impacts that directly result frol: its issuance by the DOE. However, the effects of adopting the proposed standard as a mandatory code by states and local code entities could impact institutions. Because of the widespread existence of randatory state energy codes that stipulate minimum (ECII) energy conservation measure levels for new residences, adoption (as opposed to implementation) of Volfes as a mandatory standard to update existing codes is unlikely to adversely iripact state and local institutions. However, it is possible that adoption of the proposed voluntary standard would be accompanied by some political controversy, hecause there are numerous interest aroups that would be affected by code modification.

While the large nurber of user-nodifiable paraneters in the proposed voluntary standard riake it very flexible, this feature also increases the possibility that if the standard is adopted as a code, it may contain a number of politically negotiated parameters. Adoption of a fuel-specific codt such as the VOLPES standard ray also cause some political and institutional irapacts in states where energy codes are presently fuet-blind. In a given locale, the voluntary standards produced (by the VOLPES computer progran) for different fuels usually do not have identical EC: requirements or associated constructioi costs. This feature may result in a certain degree of change in the local rarket share held by a given fuel.

Enforcenent of the voluntary standard as part of local building codes could require different procedures than those typically used for current energ! codes in most states. Code enforcement officials ma also need additional training and/or equipment (computers). However, the nature and extent of 
enforcement-related impacts would depend on the features of the proposed voluntary standard as adopted by state or local governments, as well as the compliance paths that are permitted. 


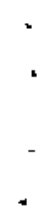




\section{ACKNOWLEDGMENTS}

A number of organizations and individuals contributed to the preparation of this assessment. Funding for the project was provided by the Department of Energy (DOE), Buildings and Community Systeris Division under the direction of John Milthone. Program management at DOE was provided by Jean Boulin, and contract monitoring by Stephan walder. Technical recomendations incorporated in the proposed standard were prepared by the American Society of Heating, Refrigerating and Air-Conditioning Engineers Special Project 53 Committee. Michael Brambley, and previously, Allen Lee served as Program Managers for the Residential Standards Progran at Pacific Northwest Laboratory (PHL). Jenifer Callaway served as Task Leader for the activities conducted under the Regulatory Analysis. Graham Parker and Joe Roop directed the research for the envirommental assessment and the economic andysis, respectively. The PlL team directly responsible for the research and report preparation included Grahan Parker, Don Hadley, Jenifer Callaway, Sarah liarsh, Joe Roop, Z. Todd Taylor. Z. Todd Taylor also provided valuable ongoing guidance and technical support for the analysis of the standard. Recognition is also due Glen wilfert and James Droppo for their previous indoor air quality rodeling and impact assessment of building energy standards. 


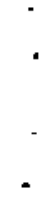




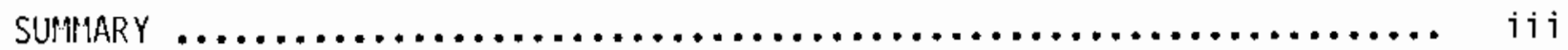

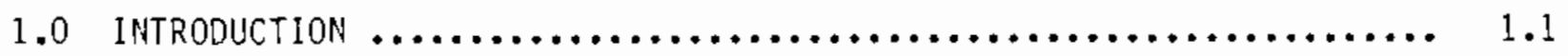

1.1 BACKGROUND $\ldots \ldots \ldots \ldots \ldots \ldots \ldots \ldots \ldots \ldots \ldots \ldots \ldots \ldots \ldots \ldots \ldots, 1.1$

1.1.1 Legislative Background $\ldots \ldots \ldots \ldots \ldots \ldots \ldots \ldots \ldots \ldots \ldots \ldots \ldots \ldots \ldots, 1.1$

1.1.2 Summary of the Original Proposal $\ldots \ldots \ldots \ldots \ldots \ldots \ldots . . .2$

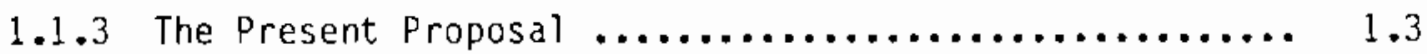

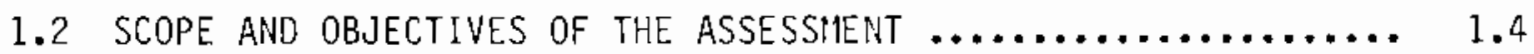

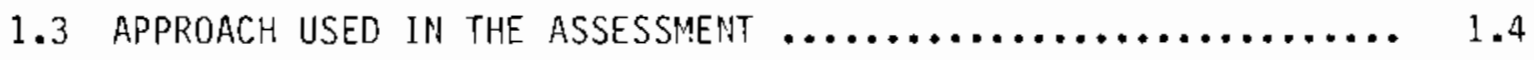

2.0 DESCRIPTION OF THE PROPOSED StAMdARD AND ALTERHATIVES $\ldots \ldots \ldots \ldots \ldots .2 .1$

2.1 THE PROPOSED STANDARD $\ldots \ldots \ldots \ldots \ldots \ldots \ldots \ldots \ldots \ldots \ldots \ldots \ldots \ldots \ldots \ldots \ldots \ldots, 2.1$

2.1.1 The Automated Residential Energy Standard Computer

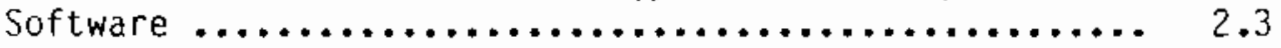

2.2 NO-ACTION ALTERNATIVE: CONTINUED USE OF CURRENT ENERGY CODES AND ENERGY-RELATED BUILDING PRACTICES $\ldots \ldots \ldots \ldots \ldots \ldots .2 .7$

2.2.1 Base Case Energy Efficiency Requirements ............ 2.8

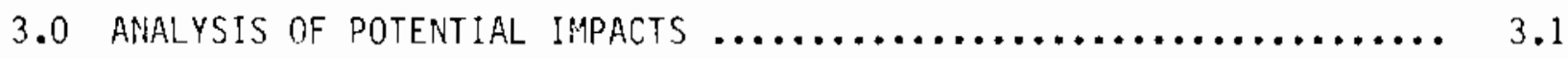

3.1 FOCUS OF THE ASSESSHENT $\ldots \ldots \ldots \ldots \ldots \ldots \ldots \ldots \ldots \ldots \ldots \ldots \ldots \ldots \ldots \ldots \ldots \ldots, 1$

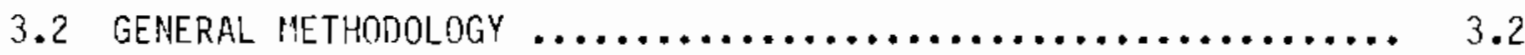

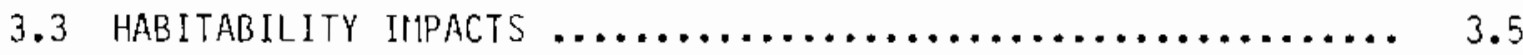

3.3.1 Approach to Indoor Air Quality Analysis ............. 3.5

3.3.2 Determinants of Indoor Air Quality and Assumptions

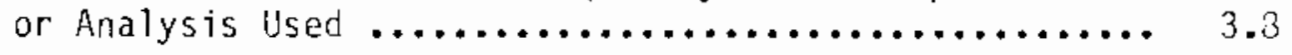

3.3.3 Results of Indoor Air Quality Siriulations ............ 3.10

3.3.4 Other Health and Safety Concerns ................. 3.35 


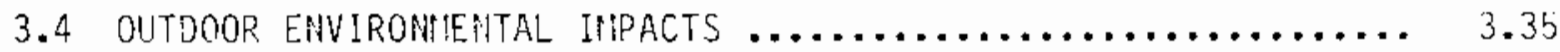

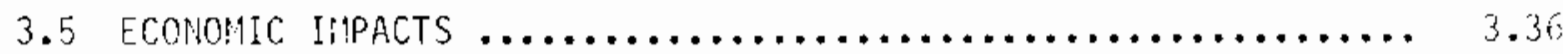

3.5.1 Direct Economic Impacts of the Proposed Standard ...... 3.36

3.5.2 Total Econoric Impacts of the Proposed Voluntary Standard $. . . \ldots \ldots \ldots \ldots \ldots \ldots \ldots \ldots \ldots, 3.38$

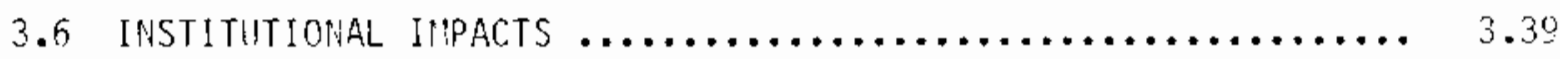

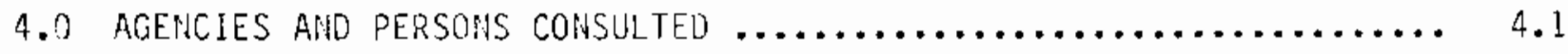

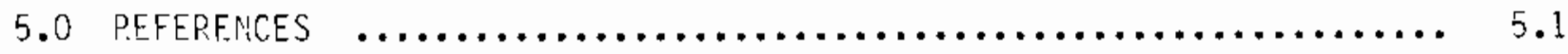

APPENIIX A - DESCRIPTION OF CASE-STUDY RESIDE!CES UNDER THE

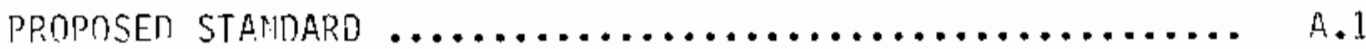

APPENDIX B - DEVELOPHENT OF THF. BASELIHE CASE STUOY RESIDENCES $\ldots \ldots \ldots$. B.

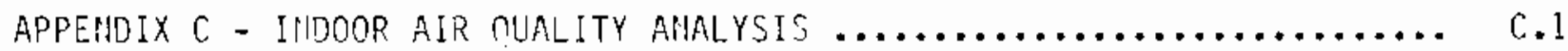

APPENIIX D - hEALTH IMPACTS OF SELECTED AIR POLLIJTANTS $\ldots \ldots \ldots \ldots \ldots \ldots . . .1$ 


\section{$\underline{\text { TABLES }}$}

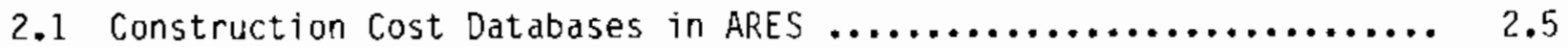

3.1 Locations and Fuels Examined in the Assessment .............. 3.4

3.2 Summary of Incremental Changes in Indoor Air Quality for the

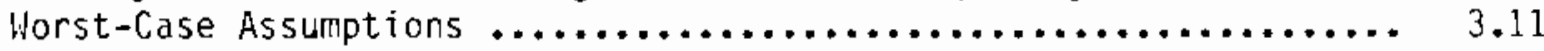

3.3a Sumary of Incremental Changes in Pollutant Levels from the Base Code to the Proposed Voluntary Standard for Albany ......... 3.14

3.3b Summary of Incremental Changes in Pollutant Levels from the Base Code to the Proposed Voluntary Standard for Atlanta ........ 3.15

3.3c Summary of Incremental Changes in Pollutant Levels from the Base Code to the Proposed Voluntary Standard for Denver ......... 3.16

3.3d Summary of Incremental Changes in Pollutant Levels from the Base Code to the Proposed Voluntary Standard for Fort Worth ..... 3.17

3.3e Summary of Incremental Changes in Pollutant Levels from the Base Code to the Proposed Voluntary Standard for Minneapol is ..... 3.18

3.3f Summary of Incremental Changes in Pollutant Levels from the Base Code to the Proposed Voluntary Standard for Pasadena ....... 3.19

3.3g Suminary of Incremental Changes in Poliutant Levels from the Base Code to the Proposed Voluntary Standard for Phoenix ........ 3.20

3.3h Summary of Incremental Changes in Pollutant Levels from the Base Code to the Proposed Voluntary Standard for Providence ...... 3.21

3.3i Sumiary of Incremental Changes in Pollutant Levels from the Base Code to the Proposed Voluntary Standard for Seattle ........ 3.22

3.3j Sumary of Incremental Changes in Pollutant Levels from the Base Code to the Proposed Voluntary Standard for Tampa ......... 3.23

3.4 Organic Emissions from New Building Insulation liaterials $\ldots . . . . .3 .32$

3.5 Air Exchange Rate Required to Maintain $40 \%$ to $60 \%$ Relative Huriidity Indoors at $70^{\circ} \mathrm{F}$ 



\subsection{INTRODUCTION}

The objective of this environmental assessment (EA) is to identify the potential environmental impacts that could result from the proposed voluntary residential standard (VOLRES) on private sector construction of new residential buildings. In this section, the scope, objectives, and approach of this EA are presented.

\subsection{BACKGROUND}

The proposed voluntary standard for new residential buildings has undergone considerable revision since its inception in 1977. This section provides a brief legislative history of the standard and then describes the original and present proposals.

\subsubsection{Legislative Background}

As originally enacted, Title III of the Energy Conservation and Production Act, Pub. L. No. 94-385, 90 Stat. 1144 et seq., required action to develop, pronulgate, implement and enforce compliance with performance standards to iriprove energy efficiency of all new buildings in the nation. The regulatory nature of this action was modified by the Energy Conservation Standards for New Buildings Act of 1976, as amended, (ACT) 42 U.S.C. 6831 et. seq. Responsibility for this action was transferred to the U. S. Department of Energy (DOE) on August 4, 1977, with the passage of Section 304(a), 42 U.S.C. Sec. 7154, of the Oepartment of Energy Organization Act, Pub. L. 95-91.

In November 1979, DOE published proposed performance standards in the Federa? Register, 44 FR 68120, et seq. The standards, expressed as maximum energy consumption levels (Btu per square foot per year), were very controversial, generating over 1800 comrients. Many commenters expressed concern that the proposed standards were not technically practicable or economically achievable. Furthermore, many commenters stated that the proposed standards placed too great a reliance upon the use of a complex computer program which many commenters said they neither understood nor could afford to use. 
Less than a year after the publication of the proposed standard, the Act was again amended by Section 326 of the Housing and Community Development Act of 1980, Pub. L. No. 96-399 (October 8, 1980). This amendrient required that DOE promulgate interim standards and extended the promulgation date of the final standard to April 1, 1983. In addition, the Act required that denonstration projects be conducted in at least two geographica? areas.

In August 1981, Congress again ariended the Act and deferred the appropriation for the program from the 1981 fiscal year to the 1982 fiscal year. Subtitle D of Title 10 of the Omnibus Reconciliation Act of 1981, Pub. L. No. 97-35, amended the Act to create the term "voluntary performance standard," eliminated the provision for a possible statutory sanction for nonconpliance, and added a provision that, except for federal buildings, "voluntary standards will be developed solely as guidelines to provide technical assistance for the design and construction of energy efficient buildings."

\subsubsection{Sumary of the Original Proposal}

The most significant aspect of the proposed Building Energy Performance Standards (BEPS), issued in 1979, was that they were a performance standard that set energy limits for the building as a whole. BEPS attempted to combine energy use of, and permit trade-offs for specific energy-using systeras such a: heating, cooling or domestic hot water. The proposed standards consisted of three requirements. First, energy budget levels would be set; second, they would be applied to a specific building design to obtain an annual rate of consumption; and third, the estinated general rate of energy consumption would be calculated using a method established by DOE. The whole process required the use of a computer simulation to demonstrate that the designed energy consumption of a new building did not exceed the energy level specified for a residential building of its type in its applicable clinate area. The BEPS was based on life-cycle cost analyses and defined different residential building types (multi-family high-rise, multi-family low-rise, single-fanily attached and single-fanily detached) as well as a procedure to select an appropriate climate zone from 78 Standard Metropolitan Statistical Areas (SMSA).

DOE recognized that many aids, such as model codes or building energy simulation software, would be needed to reduce compliance complexities. It 
also acknowledged that tools needed to be in formats familiar to members of the building industry. These compliance assistance tools were in the process of being developed by $D O E$ when the implementation sections of the statutes were repealed by the Omnibus Budget Reconciliation Act. The entire package of compliance assistance tools was never completed, but a slide ruie and A Gujde to Designing and Constructing Energy Efficient Homes was issued in 1983.

\subsubsection{The Present Proposal}

In response to the revised Tegislation and to comments made on the proposed BEPS, DOE is now reproposing voiuntary performance standards for the nonfederal (private) sector. Because of the difference in the economics and process of federal design and construction of residential buildings, DOE is issuing separate standards for the federal and private sector. Mandatory standards for new federal residential building had been developed previously and are soon to be issued by DOE.

The proposed voluntary standard is for private sector construction and for federally-subsidized private housing only. As such, DOE would not be regulating private sector construction, but rather issuing guidelines to provide technical assistance for the designs and construction of energy-efficient buildings. The proposal represents a significant federal effort to help the private sector develop energy conservation standards without regulatory intrusion. To develop the proposed voluntary standard DOE has worked closely with a special projects comittee from the American Society of Heating, Refrigerating and Air-Conditioning Engineers, Inc. (ASHRAE). The research project jointly undertaken by DOE and ASHRAE culminated in the proposed interin voluntary standard.

The proposed voluntary standard is presented in the format commonly used by the private sector standards-setting organization rather than as a federal regulation. For example, the proposal contains extensive explanatory materiat not normally included in federal standards. By submitting the proposed interin standards in a form that is likely to be better understood and more readily used in the private sector, DoE hopes to improve the standard's transferability. 
As defined by the Act, the proposed voluntary standard serves as a guideline for the design of new residences; it does not apply to the operation, maintenance or energy consumption of a building once it is built. The proposed voluntary standard operates by setting an energy cost goal for a building (i.e., a quantified target for energy cost at the design stage) and a method to calculate whether the design meets that goal. Through the use of the software ARES (Automated Residential Energy Standard) which supports the proposed voluntary standard, users can also create "packages" of energy conservation compcnents that meet the energy consumption goal. Additional details on the proposed standard are provided in Section 2.1 .

\subsection{SCOPE AND OBJECTIVES OF THE ASSESSMENT}

The proposed voluntary residential bujlding standard sets minimur perfornance levels to be applied during the design of private sector residential buildings. The proposed voiuntary standard is not expected to result in radical changes in residential building design. This assessment addresses the incremental environmental impacts attributable to the changes that result from application of the proposed performance standard. Those impacts were determined by comparing case-study residential prototypes designed first with current energy conservation measure (ECil) levels, (the baseline) with prototype units that meet the proposed standard. Various quantified and unquantified environmental consequences attributable to increasing energy conservation in residential buildings are discussed in this report. Emphasis is placed on increnental changes associated with the ECils required to meet the VOLRES standard instead of current codes or practices, insofar as they can be identified.

\subsection{APPROACH USED IN THE ASSESSIIENT}

In this study, potential impacts were examined by modeling three types of residential buildings in ten locations across the United States, first to meet baseline ECH levels, then to ECM levels required by VOLRES standard. Althou,gh the prototypes studied do not include all potential ECli combinations that wo dld meet either current codes or the proposed voiuntary standard, they provide enough diversity to constitute a defensible analyticai base. The prototypes 
include the most common housing types, foundations, and space-conditioning systems used in current residential construction. The ten locations were selected to provide a wide range of climatic conditions in which to estimate the effect of the proposed voluntary standard.

Impacts to the indoor environment, which were found to be negligible, are expressed only in the form of incremental changes in to a single home. The economic costs and benefits of widespread adoption of the proposed voluntary standard by state and local code enforcement entities could be more substantial. These affect not only individual consumers but the society as a whole. As a result, an effort was rade to estimate aggregate econonic impacts, using two scenarios for the rate of adoption of the proposed voluntary standard. The results of the econoric analysis have been sumnarized in this document. For a more extensive discussion of the approach used and results obtained in the economic analysis, see llarsh and Roop (1988).

Section 2 of this EA describes the proposed voluntary standard and the major alternative considered in the environmental assessment. Section 3 provides details on the general approach used in the assessment, followed by estimates of specific indoor air quality changes, a discussion of the husan health impacts of indoor air pollution, probable outdoor environmental inpacts, a summary of estimated socioeconomic impacts, and institutional impacts. In general, these specific discussions include background information, the analytic methodology used, and the conclusions. Appendix A contains detailed descriptions of the assumptions used to generate the configurations of the case-study prototype residences under the proposed voluntary standard. Appendix B provides information on the current required/accepted levels of efficiency found in housing constructed today. The method used to create the baseline prototype residences is also described in Appendix $B$. Appendix $C$ provides a detailed description of the indoor air quality model used to compute pollutant concentrations. Finally, Appendix 0 documents the information used to evaluate human hearth impacts. 



\subsection{DESCRIPTION OF THE PROPOSED STANDARD AND ALTERNATIVES}

This section provides information on the proposed voluntary residential energy standard (VOLRES) and the no-action alternative considered in this assessment. Although the development of the proposed voluntary standard was mandated by legistation, adoption of the standard by the private sector is voluntary.

Nejther the DOE nor any branch of the federal government would be directly involved in implementation of either the voluntary standard as a building code or the no-action alternative, defined as a continuation of current practices and existing energy codes. Adoption of the VOLRES standard to replace or update existing energy codes or building practices would be a voluntary action on the part of state, local governments or organizations that sponsor nodel building codes, such as the American Society of Heating, Refrigeration and Air Conditioning Engineers (ASHRAE) or the Council of American Building Officials (CABO).

\subsection{THE PROPOSED STANDARD}

The VOLRES standard has been developed and proposed by the DOE in response to legislation requiring the Secretary of Energy to pronilgate voluntary energy performance standards that are designed to achieve the maximum practicable improvements in energy efficiency in new residential buildings and to encourage the use of non-depletable energy sources. In response to this legislative mandate, this voluntary standard sets forth requirements for the design of new residential buildings that would represent the most cost-effective combination of energy conservation options. This voluntary standard should lead to residential building designs that produce the maximum practicable energy savings given the criterion of economic cost-effectiveness.

This voluntary standard relies on minimizing life-cycle costs using estimated energy consumption data, construction cost data, climate data, and appropriate consumer financial parameters. The VOLPES standard is implenented through a computer program documented in Recomendations for Energy. 
Conservation Standards and Guidelines for New Residential Buildings,

Volume II: Automated Residential Energy Standard - User's Guide (draft report, to be published by the DOE).

The proposed voluntary standard sets forth recomended requirements for the energy-affecting construction components of residential buildings, including insulation levels, windows (amount, giazing layers, sash type), infiltration control measures, space conditioning equipment, and domestic hot-water conditioning equipment. The VOLRES standard includes separate requirenents for each of three generic housing types: 1) single family detached housing, 2) nultifamily attached housing, and 3) manufactured housing. Within each housing type, separate requirements are set forth for each of five spaceconditioning equipment combinations: 1) natural gas heat with electric cooling, 2) $0 i 1$ heat with electric cooling, 3) liquid propane gas (LPG) heat with electric cooling, 4) electric resistance heat with electric cooling, and 5) electric heat-pump heating and cooling.

The voluntary standard requires that residential housing be constructed to minimize overall costs to the homeowner over the assumed life of the home. The monetary factors included in the assessment of these life-cycle costs are initial construction costs, operation and maintenance costs, energy costs, tax effects, and resale value of the home, all of which are discounted to adjust for inflation and lost-opportunity costs. A house complies with the voluntary standard if its annual space-conditioning energy cost is shown to be less thin or equal to that of a similar house constructed to achieve minirum overall life-cycle costs to the homeowner, given local construction costs, fuel prices, and economic conditions.

The proposed voluntary standard includes minimum recomendations for infiltration control measures, but it allows stricter measures to be implemented at the user's option if necessary to meet the energy-cost budget. The mininum recomendations reflect current building practices, such that air exchange rates (assumed to average approximateiy 0.5 air changes per hour) and indoor air quality are not adversely affected by the standard. The optional tighter measures are specified such that air exchange rates do not fall belcw 0.35 air changes per hour, the threshold below which forced ventiitation would 
be required to maintain acceptable air quality. (a) The tighter measures are never required, but are offered as an option to allow users to select less stringent component efficiencies (eg., lower R-values for insulation).

\subsubsection{The Autonated Residential Energy Standard Computer Software}

Procedures that automate the development of specific criteria to comply with this voluntary standard are embodied in a computer program, Autonated Residential Energy Standard (ARES). This progran maintains data bases of estimated residential energy consuription for a variety of locations, of construction costs, of economic and financial parameters, and of typical building characteristics. Using these data, ARES identifies for each locality the combination of energy conservation measures that results in the minimun overal1 Tife-cycle costs to the homeowner. The annual energy costs of the optimal house constitute the target energy costs required by the voluntary standard. ARES then provides an initial set of prescriptive requirements (a package) that meets this energy budget, and a point systen designed to allow evaluation of specific building designs against the prescriptive target. The user can also generate "alternative [prescriptive] packages" by changing one or more of the minimun requirements of the initial package.

The ARES progran is designed to be used by code officials responsible for establishing energy codes in specific jurisdictions. The user can modify the various economic, financial, and climatic inputs to ARES to tailor the resulting voluntary standard to specific localities. The progran also provides alternative compliance naterials in the form of a flexible point systen or an energy cost target (see below).

\section{The Energy Data Base}

The ARES energy data base contains annual heating and cooling loads for residential housing built to any common level of thermal integrity in any of 386 locations throughout the United States. The energy data are derived from parametric computer simulations of residential energy performance. The developnent and format of these data are documented in a draft report to be

(a) These estimated air exchange rates do not include the effects of occupants, which increase infiltration slightly. 
published by the DOE entitled Technical Documentation for a Residential Energy Use Data Base Developed In Support of ASHRAE Special Project 53.

The Cost Data Base

The ARES cost data base contains 1986 construction costs for all comon ceiling, wall, crawispace and basenent insulation levels; window types; and HVAC equipment efficiencies. Twelve sets of cost data are included representing 11 regions of the United States and the national average. Table 2.1 lists the states included in each region.

When using ARES, local jurisdictions may choose the most appropriate regional data base. The selected data base may also be altered if necessary :0 reflect locai conditions by changing construction costs and/or adding or dele:ing component levels as appropriate.

\section{The Life-Cycle Cost Optimization}

The life-cycle cost calculations required by the proposed voluntary standard reflect the value of energy conservation measures to a typical home. owner. The life-cycle cost is defined as the sum of the net present values cf the following cash flows over a seven-year time period:

- down payment on loan

- loan fees and other closing costs

- up-front interest charges (points) on loan

- tax deductions on points

- mortgage payments over the period of analysis

- tax deductions on nortgage interest over the period of analysis

- space conditioning energy costs over the period of analysis

- non-fuel operation and maintenance costs over the period of analysis

- resale value of home at the end of the period of analysis.

Only the portion of loan, tax, etc. costs attributable to the ECMS are important in the iife-cycle cost calculations.

The 7-year period used in the 7 ife-cycle analys is reflects the median turnover period of home ownership and mortgages. All cash flows are discounted at a user-modifiable alternative investment rate. llortgage payments and in:erest fractions (i.e., the fraction of each mortgage paynent that reflects ths 
Table 2.1. Construction Cost Databases in ARES

\begin{tabular}{|c|c|}
\hline Region & States in Region \\
\hline National Average & A11 \\
\hline New England & $C N, M A, I I E, N H, R I, V T$ \\
\hline Mid-Atlantic & $D C, D E, M D, N J, N Y, P A$ \\
\hline Mid-South & $G A, N C, S C, V A, W V$ \\
\hline Florida & $\mathrm{FL}$ \\
\hline South Central & $A L, A R, K Y, L A, I I S, O K, T N, T X$ \\
\hline Central & $\mathrm{IA}, \mathrm{KS}, \mathrm{N10}, \mathrm{NB}$ \\
\hline North Central & $I L, I N, M I, H N, N D, O H, S D, H I$ \\
\hline Mountain & CO, NV, UT, WY \\
\hline Southwest & $A Z, N M$ \\
\hline Pacific Southwest & $A K, C A, H I$ \\
\hline Pacific Northwest & $I D, M T, O R, W A$ \\
\hline
\end{tabular}

interest) are based on common financial calculations and current economic parameters that must be supplied by the user. The resale value of the home is assumed to be identical to its initial cost in current dollars at the end of the period of anaiysis. Thus the real value of the hone's ECMS is assumed to decline at the rate of inflation.

The ARES program identifies the hypothetical house with the minimum life-cycle cost via an exhaustive search of all combinations of insulation levels, equipment efficiencies, and window types available in the cost data base. In concept, the energy and construction costs of houses built to every combination of conservation options are calculated and compared. The combination with the lowest overall life-cycle cost is used as the basis for the energy cost budget. However, several constraints are applied during the optimization. First, the optimization assumes that the window area of the house is equally distributed on the four cardinal orientations. Though this seldom matches the construction of a particular house, it represents the average condition of large numbers of residences. Second, the optimal Teveis of ceiling insulation, wall insulation, windows, and equipment efficiencies are forced to be the same regardiess of the foundation type. This is accomplished by 
identifying a prevalent foundation type for each location and optinizing a prototypical house with that foundation. Once the upper envelope conservation levels are established, the foundation insulation levels for each additional foundation type are optimized assuring the same upper envelope is installed. Thus, each foundation type results in a unique energy cost budget.

\section{Prescriptive Package Compliance Alternative}

The ARES program provides prescriptive packages of options that will neet the energy cost budget associated with the optimal combination of components identified by the life-cycle cost optimization. One prescriptive package is created for each of the 5 fuel/equipment conbinations. However, each prescriptive package differs from its original optimal conbination of options (that produced the energy budget) due to a constraint applied in the program. The prescriptive packages assume that windows are equally distributed on the east and west faces of the house, rather than on all four faces as is done in the original optimization. This constrained configuration is intended to approxmate the worst possible orientation scenario, so that virtually any house, regardless of its window placernent, would have energy performance at least as good. The purpose is to minimize the possibility that a house allowable under the prescriptive compliance path would not be allowable under the points conpliance path (described below). Given this constraint, ARES identifies the combination of options that meets the energy cost budget with the minimum construction cost.

In addition to the five voluntary standard prescriptive packages, the user of the program (state or local governments or building code officials) may develop additional packages to satisfy local preferences. This is accomplished by applying specific constraints, such as a fixed-wall insulation level, or window-to-floor area ratio, then allowing ARES to identify the other components of the house that result in acceptable energy use at a rininum construction cost. This allows code officials to create simple conpliance approaches for technologies and preferences common to their localities. 


\section{Point System Compliance Alternative}

The point system printed by ARES is designed to allow builders to deviate from the prescriptive packages identified by the cost optimization while maintaining thermal integrity. Various levels of conservation options are assigned "points," which are tabulated in the compliance materials printed by the program. The points are directly proportional to the annual energy costs of the home, providing builders the capability to evaluate the energy cost impacts of various construction options. Options that may be evaluated by the point system include various insulation levels, equipment efficiencies, and various window parameters, including number of glazings, solar transmittance, and orientation.

\section{Performance Compliance Alternative}

The proposed voluntary standard allows construction of any house that has annual energy costs less than or equal to those of the optimal house. To accommodate new and innovative technologies, the standard provides the option of evaluating the energy performance of a design against that of a similar house that complies with the prescriptive requirements. An energy analysis must be conducted for both the design house and the target house using a calculation technique appropriate for the technologies involved. Typically, this requires use of a computer simulation tool.

\subsection{NO-ACTION ALTERNATIVE: CONTINUED USE OF CURRENT ENERGY CODES AND ENERGY-RELATED BUILDING PRACTICES}

As noted above, the proposed voluntary standard is a recomended level of energy efficiency for residential building components, the adoption and implementation of which in the private sector is voluntary. For the purpose of this assessment of potential impacts of the voluntary standard's inplementation, the no-action alternative consists of the continued application of the energy codes and building practices that are currently in use.

At the present time, thirty-three states have adopted mandatory energy efficiency codes for residential buildings. Most other states have adopted model energy codes which are enforced at the discretion of local governments. 
Most of these mandatory and model codes are based on several prominent standards that were developed in the late 1970 s and early 1980 s by organizations such as ASHRAE, the Council of American Building Officiais (CABO), and Buildirg Officials and Code Administrators International, Inc. (BOCA). These parent standards tend to be technically compatible, with ninimur requirenents usually expressed as maximum allowable overall thernal transmittance values $\left(U_{0}\right)$ for major envelope components and minimum values of allowable themal resistance (R) for perimeter insulation of slabs-on-grade (NCSBCS 1985). Criteria are expressed as or drawn from graphs based on annual heating degree days (HDD).

Most states with mandatory codes have made some modifications to the parent standards in their adoption process. Since HDO can vary widely in a given state, one common approach is to establish several state code levels for a limited number of climatic zones that span the state's HDD range. This approach heips avoid the problems of enforcing a code that could fluctuate substantially due to the presence of numerous microclimates. Other modificatiors may also be adopted, such as prescribing envelope performance on the basis of the heating and cooling appliances (and their efficiencies) selected for a new home. State energy codes are reviewed and updated from time to time. llost states have updated their code at least once since initial adoption (NCSBCS 1985).

Several states (including California, Florida, Hawaii, Louisiana, Nevada, North Carolina, Washington, Oregon and Alaska) have developed their own codes rather than adopting modified versions of the parent standards (although there frequently is a perceptible relationship to the latter). Some of these codes have sophisticated compliance mechanisms using computer software (eg., California's CALPAS progran); almost all have a variety of paths to compliarco so as not to limit design of and construction techniques for new homes.

\subsubsection{Base Case Energy Efficiency Requirements}

Estimation of the potential impacts of the VOLRES standard was based or a rinited number of case studies, since the inherent flexibility of the voluntary standard permits an almost limitless variety of component packages (see sec.. tion 3.2, General llethodology). For each location included as a case study. the corresponding baseline (existing) code or level of current building 
practices was also deternined. The following discussion provides some information on how the base efficiency leveis were developed.

State energy codes are often expressed as perfornance leveis for individuai envelope and space-conditioning components. Quite frequently, the efficiency of the wall components (opaque areas, windows, and doors) is expressed as a single $U_{0}$ value, to permit trade-offs among levels of insulation, window area and treatment, etc. However, life-cycle cost calculations for the base codes and comparison with the proposed voluntary standard required separate efficiency values for each component.

In addition, home builders in states without mandatory codes often opt for component performance levels that exceed model codes, due to the influence of consumer denand, utility incentive programs, or other factors. (This also occurs in mandatory code states.) The opposite case also occurs, where prevailing efficiency leveis fall below the reconmended minimuras of a nonmandatory standard.

Therefore, the base code for each location was not determined by examining code regulations, but by obtaining information about the nost prevalent ECils currently installed by builders in that location. A telephone survey employing open-ended questions was used to acquire this infornation. Respondents included code enforcement officials at the state and local ievei; prominent Tocal builders, developers and designers; utility staff and other knowledgeable persons. Three to four sources of information were sought for each location; nore were used if it was difficult to obtain a consensus about typical construction practices.

Baseline ECH levels for manufactured homes were obtained in a similar manner, but the source was a telephone survey of over 80 manufacturers conducted by Pacific Northwest Laboratory (PHL) in the fall of 1987 (Nesse et al. 1987). Levels installed by the surveyed manufacturers often exceeded those required to meet the Department of Housing and Urban Development (HUD) Hanufactured Homes Construction and Safety Standards (IHCSS), a pre-emptive national nininum required for this type of housing. Where this was the case, current practice rather than IHCSS was used to represent the base case for this type of housing. 
. 


\subsection{ANALYSIS OF POTENTIAL IMPACTS}

This chapter presents an assessment of the potential impacts of adopting the proposed voluntary energy efficiency standard (VOLRES) for new residential buildings. The voluntary standard produces recommended levels of energy conservation measures (ECMS) for the envelope and space conditioning components of new homes. If the ECMs currently in use are changed to those recominended in VOLRES, the difference in materials, energy use and cost could trigger certain environmental and socio-economic impacts. In sone instances, the inpacts can be estimated in quantified terms. Other impacts, however, are difficult to quantify because of lack of data, so comparisons are in qualitative terms.

\subsection{FOCUS OF THE ASSESSMENT}

The proposed voluntary standard recomends combinations of EClis that minimize the life-cycle cost of a residence. Use of the recommended EClis could affect building habitability (the indoor environment), the outdoor environment, the nation's economy, and the institutional processes associated with residential construction. Changes in the habitability of residential buildings include potential impacts on indoor air quality and the related human health impacts. Both are discussed in Section 3.3. The outdoor environnent is affected by changes in the energy consumption of residential buildings and by possible slight changes in the various process waste streams fron insulation manufacturing. These potential iripacts are discussed in Section 3.4. Economic and social impacts stemming from adopting the proposed standard have been examined in a separate report (Economic Analysis, Proposed Energy Conservation Standard for New Residential Buildings) (a) and are summarized in this report in Section 3.5. Adopting the proposed voluntary standard as a mandatory energy code could also lead to certain institutional impacts for state and local agencies that regulate building practices. Federal agencies, however, are not

(a) Marsh, S. J., et a1. Draft report to be pubtished in 1988. Pacific Northwest Laboratory, Richland, Washington. 
likely to be impacted. The nature and extent of such institutional impacts are somewhat conjectural, so discussion of these impacts in Section 3.6 is quite limited.

This report does not address potential changes in aesthetic qualities of residential buildings, because those are design choices that are not dictated by VOLRES, which is a performance standard.

\subsection{GENERAL METHODOLOGY}

The proposed VOLRES standard is a highly flexible approach to specifying requirements for the energy-efficient design of residential buildings. As a performance standard based on minimized life-cycle costs, its flexibility is enhanced by the use of local climatic conditions in combination with local fuel prices and local construction costs. Economic parameters used in the lifecycle cost calculations (e.g., interest rates) may also be adjusted by the user to reflect local circumstances or regulatory positions. The net result is a standard that can easily be taflored to local conditions.

As noted in Section 2, the proposed voluntary standard is generated by a menu-driven computer progran (ARES). The software employs an interactive format that pernits the user to select various settings, options and restrictions. Sone input files (e.g., ECM costs, ECH levels to be considered and econonic variables) can also be modified (edited) by the user. Varying selections in the menus or changing inputs will also rodify the VOLRES package ard point systen that results in minimum Tife-cycle cost. For example, changing important economic parameters, such as the discount rate, or building characteristics, such as the percentage of window area facing south, can result in specification of a different heating appliance efficiency, wall insulation level, or window glazing. The corresponding energy target and point system woutd also change.

Because of this flexibility, analysis of the VOLRES standard is based ch a set of case studies. The case studies consist of prototype buildings hypothetically located in ten locations across the United States. Each prototype bujlding in each location was equipped with ECHs that were generated by specific settings in ARES. The assessment was constrained by limiting the locations 
and fuel/appliance combinations to be studied. This process provided a number of hypothetical building configurations that meet the proposed voluntary standard, and their associated costs and energy usages under VOLRES. The results were compared to the components, energy use and costs of identical buildings that would meet the codes or current building practices in the same locations. The differences (deitas) were assumed to approximate the potential changes resulting from the use of the voluntary standard.

The settings and assumptions that were used to develop VOLRES packages for the case studies are summarized below. Greater detail on these factors can be found in Appendix $A$ and in the report on the economic analysis that accompanies this assessment (Marsh et al. 1988). The economic report also includes results of sensitivity studies that were conducted to examine the possible range of changes in the cost and energy use characteristics that would be induced if several of these assumptions and settings were nodified.

Case Study Locations. Ten cities distributed across the continental United States were selected as locations where VOLRES would be compared to existing energy efficiency-related bujlding practices and requirements. These locations (see Tabie 3.1) represent a range of heating and cooling degree day values that span the predominant climatic conditions in the United States.

Building Prototyges. Residential structures are represented as generic prototypes in ARES (single family and rulti-family site-built homes, and single-wide ranufactured/robile hores). Tabie A.1 in Appendix A lists the prototypes used in ARES and the foundation options which were studied in this analysis. Table A.2 in the same appendix provides the dimensions of the relevant components, by prototype.

Fuels. The voluntary standards generated by the ARES software are specific to fuel/heating appliance combinations selected by the user. In this analysis, VOLRES standards were created for the two predorinant heating fuels in each location studied. However, ARES creates separate voluntary standards for electric forced air and electric heat purip appliances, so where this heat 
IABLE 3.1. Locations and Fuels Examined in the Assessment

\begin{tabular}{|c|c|c|c|c|c|c|c|c|}
\hline \multirow[b]{2}{*}{ Location } & \multicolumn{4}{|c|}{ Single and Multi-Family } & \multicolumn{4}{|c|}{ Manufactured Homes } \\
\hline & $\overline{G a s}$ & Electricity & $\mathrm{HP}$ & $\underline{0 i 1}$ & $\underline{\underline{G a s}}$ & Electricity & LPG & $0 i 1$ \\
\hline Atlanta & $x$ & $x$ & $x$ & & $x$ & $x$ & $x$ & \\
\hline Denver & $\mathrm{x}$ & $\mathrm{x}$ & $x$ & & $x$ & $\mathrm{x}$ & $x$ & \\
\hline Fort Worth & $\mathrm{x}$ & $x$ & $\mathrm{x}$ & & $x$ & $x$ & $\mathrm{x}$ & \\
\hline Minneapolis & $x$ & $x$ & $x$ & & $x$ & $\mathrm{x}$ & $\mathrm{x}$ & \\
\hline Pasadena & $x$ & $x$ & $x$ & & $\mathrm{x}$ & $\mathrm{x}$ & $x$ & \\
\hline Phoenix & $\mathrm{x}$ & $\mathrm{x}$ & $\mathrm{x}$ & & $x$ & $\mathrm{x}$ & $x$ & \\
\hline Seattle & $x$ & $\mathrm{x}$ & $\mathrm{x}$ & & $x$ & $x$ & $x$ & \\
\hline Tampa & $\mathrm{x}$ & $x$ & $x$ & & $x$ & $\mathrm{x}$ & $x$ & \\
\hline Albany (a) & $x$ & $x$ & $x$ & $x$ & $x$ & $x$ & $\mathrm{x}$ & $x$ \\
\hline Providence (a) & $x$ & $x$ & $x$ & $x$ & $x$ & $x$ & $x$ & $x$ \\
\hline
\end{tabular}

(a) Multi-family residences in these locations are frequently heated with electricity, so that prototype was modeled with all four fuels.

source was used, both electricity standards were analyzed. Table 3.1 above shows the fuels selected for each case-study location. Prices used for selected fuels were current (1986) location-specific per-unit costs obtained from pub1 ished sources (see Appendix A).

Construction Costs. The ARES program contains data bases with average construction costs (1986 dollars) for twelve regions covering the continental United States. These costs are default values that can be modified by individual users of the software. For the purpose of this study, no changes were made to the default values.

Econonic Parameters. The ARES program contains a file listing the economic parameters that guide its component iffe-cycle cost calculations. In conjunction with its other files and programing, the software generates a package of components and a point system that represent minimized building life-cycle cost in the selected location (see Section 2.1). For the purposes of this assessment, the default values for the economic parameters (listed in Table 3.4) were used. 
Heating Appliance Efficiencies. The ARES progran does not permit consideration of appliance efficiencies below the mandatory minimurn efficiencies established in the National Appliance Energy Conservation Act (NAECA) of 1987 (42 USC 6201). However, ARES can select efficiencies higher than the NAECA minimum criteria for new space-conditioning equipment as it creates the proposed standard. In the building configurations created for the proposed voluntary standard, ARES occasionally selected these higher efficiencies. The NAECA minimum criteria were used, however, in developing comparative life-cycle costs of current codes and construction practices for the econonic impact analysis.

Windows. Users of VOLRES can choose the amount of fenestration (windowto-floor-area ratio), the percent facing south (except in manufactured housing), and the types of glazing that are to be considered in creating the voluntary standard. Changing any of these iterns can result in modifications in other component requirements. The settings used to develop the VOLRES standard for each case study are provided in Appendix A.

These settings were used in ARES to create ECM packages that meet the requirements of the voluntary standard in the case study locations for each housing prototype. Tables A.5 through A.7 in Appendix A 1ist the resulting proposed voluntary standard package for each prototype in each site. The tables also show the component levels estimated for the baseline (current energy code and/or building practices) in each location.

The potential impacts of the incremental changes to energy-related building components are discussed in the remaining portions of this chapter. Inpacts to the indoor and outdoor environment are largely the result of modifications to the amount of insulation and framing in the building envelope. Econoric impacts derive from the changes in the costs to produce, purchase, heat, and cool homes constructed to meet VOLRES. These latter inpacts are summarized in this chapter and more fully discussed in the economic analysis.

\subsection{HABITABILITY IMPACTS}

The following section examines the potential for changes in the habitability (indoor environment) of residential units when ECM levels are changed to 
meet the proposed voluntary standard. The discussion focuses on the projected impact on indoor air quality (IAQ) and related impacts on the health of the occupants.

\subsubsection{Approach to Indoor Air Quality Analysis}

The indoor air-quality (IAQ) analysis is based on a computer sinulation zf the generation, buildup, and dissipation of various poltutants in occupied residential buildings. A constant natural ventilation rate was assumed for all prototypes in all locations for both the base code and the proposed voluntary standard simulations. The rate used was 0.52 air changes per hour (ACH), which is representative of typical rates for current new residential construction (BPA 1988, Grisisrud et a1. 1982). (For more information on fresh air ventiletion see Appendix C, Section C.?.2.1.) In ARES, this rate is the result of selecting the "Normal" Infiltration (Construction) Package (see Section 2.1). Therefore, the IAQ computer simulation detected only those changes that resulted fror certain envelope modifications (those that altered the insulat on mass in the prototype homes). Formaldehyde, which is emitted by insulation materials, was the only (measidred) pollutant for which the estinated concent-ation changed. Because the air exchange rate was held constant, levels of indoor air pollutants that emanate from sources other than building material; (e.g., radon) were not affected by changes that allowed the building prototyses to meet the proposed standard rather than current encrgy codes or building practices.

A slightly different approach was used in order to test a "worst case" impact of the voluntary standard. In the worst case scenario, the baseline homes were assuned to have "normal" infiltration, while the VOLRES homes were modeled with "tight" infiltration construction. This test was carried out cnly for study homes in Ft. Worth, the location where use of the proposed standard resulted in the greatest increase in insulation materials in the initial corlparison. A description of this test and the results are presented in Section 3.3 .3 .1 .

Because of the complex nature of indoor air quality studies, only the major aspects of the approach to the analysis are presented in this section. More detailed information may be found in Appendix $C$. 
Studies of IAQ and related human health impacts are a relatively recent development, and some aspects of both the behavior of known pollutants and human epidemiological responses are not clearly understood or documented. For example, recent reviews indicate that, for many pollutants, there is no consistent link between outdoor ambient and indoor concentration levels; indoor pollutant levels often exceed outdoor levels (Yocum 1982; Walsh, Dudney and Copenhaver 1984). However, by considering both indoor and outdoor pollutant source relationships, the magnitude of monitored indoor values can be explained (Wadden and Scheff 1983). These relationships provide the basis for predicting incremental changes in IAQ. The approach used in the analysis of the proposed voluntary standard was designed to estimate the expected concentrations of selected indoor air pollutants. Although any residential unit could have IAQ problems due to the presence of a wide variety of substances and/or activities (particuiarly if accompanied by an inadequate fresh air supply or unusual indoor pollutant release rates), this analysis focuses on changes to the normal range of pollutant emissions found in residences. (See Table C.3 in Appendix $C$ for a concise listing of the ranges used in the air quality analysis.)

The predicted poliutant levels under the baseline and proposed voluntary standard were derived by using a computer simutation approach that has been used and accepted by many IAQ experts (e.g., Miksch, Holiowell and Schmidt 1982; (lolhave 1982). Pollutant concentrations estimated by this method have corresponded reasonably well with monitored pollutant concentrations.

Incremental changes to indoor air-pollutant concentrations were estimated by computing concentration values for both the case study prototype homes configured to mect existing energy codes, and for identical hores that meet the proposed voluntary standard in each location. The primary focus of this assessment is on those pollutants that have suspected adverse effects on human health (particulate matter, $\mathrm{CO}, \mathrm{CO}_{2}, \mathrm{NO}_{2}$ radon, and formaidehyde). A number of studies have been made (see Table C.1 in Appendix $C$ ) of the release rates of these pollutants from various building materials. The enission rates used in the IAQ modeling effort were derived from this literature. llost quantitative 
IAQ research to date has been focused on the pollutants listed above. Therefore, while other pollutants are present inside buildings, no atternt was lade to model their expected concentrations.

The 1 AQ model computed the long-term, steady-state concentrations for the six poltutants of interest. Average outfoor pollutant concentrations (fron the air and underlying soils) are normally treated as background leveis to which internaliy-generated pollutant emissions are added. For this analysis, the concentration of outdoor pollutants was considered to be invariable from the base case to the proposed voluntary standard, and therefore was set to zero. Concentrations for each pollutant were computed for three relcase rates: low (defined as lowest expected emission rate), medium (a typical rate), and high (a maximuri emission rate). Together these numbers span the expected range of emission rates for pollutants from sources expected to be found in the casestudy residences.

\subsubsection{Determinants of Indoor Air Quality and Assumptions or Analysis Used}

Although it is known that indoor air quality depends mainly on factors such as the building design, materials, contents, usage, and envelope tightness, the relationship anong those factors can be complex. Changes in buildirg energy standards typically affect the concentration of indoor pollutants in tyo major ways. First, a new standard can increase or decrease the air exchange rate between indoor and outdoor air by specifying allowable equivalent leakags areas. If this change results in an increase in the indoor/outdoor air change rate, indoor-generated pollutant concentrations are reduced. However, if the prinary source of a pollutant is outside the building envelope, its indoor levels may increase with a higher fresh air exchange rate.

Second, a new standard could alter the internal sources of indoor pollutants by changing the type and/or amount of various building naterials used. Various pollutants are released within the residential building continuously or intermittently. These pollutants can originate from furnishings within a building (e.g., carpets or furniture), from bujlding materials (e.g., insula. tion or particle board), or from indoor activities of building occupants (e.l., smoking, use of household products or cooking). 
As noted in Section 3.3.1, the IAQ analysis was simplified by making two assumptions about building-derived pollutants. First, the only differences in building materials between the base code and the proposed standard residence were changes in insulation levels (and framing)(a) in envelope components. Second, the air change rate of the base code and proposed voluntary standard design was assumed to be identical at $0.52 \mathrm{ACH}$.

The location-dependent envelope changes attributable to the proposed voluntary standard were provided in Table A.5 through A.7. That table also indicates the changes in insulation thickness between the baseline and proposed standard for a 11 prototypes (and their variations) at each of the ten locations. The insulation mass associated with the thickness values displayed in this table were used to estimate changes in the levels of formaldehyde in prototype residences.

Several other as sumptions were needed to model the behavior of the other pollutants considered in this analysis. Radon levels were modeled using a typical range of background values rather than attempting to determine levels specific to the locations studied in this analysis. Section C.2.3.5 in Appendix $C$ provides a more detailed discussion of the sources and causes of variability in the levels of this pollutant.

Combustion pollutants $\left(\mathrm{CO}, \mathrm{CO}_{2}, \mathrm{NO}_{2}\right.$ and particulate matter), are primarily related to activities within the residential unit. Emission rates of these pollutants are not affected, therefore, by the design or building material used. Within a residential building, cigarette smoking and use of stoves and ovens are the main sources of combustion products. On a mass basis, airborne particles, $\mathrm{CO}_{2}, \mathrm{CO}$, and formaldehyde are the major components of sidestream cigarette snoke (i.e., from the burning tip) (Girman et al. 1982). Many other

(a) When the proposed standard specifies wall insulation efficiencies of R-19 or higher, ARES assumes that 2" $\times$ 6" (rather than 2" $\times 4$ ") framing will be used to acconmodate the thicker fiberglas batts needed. Higher levels may also require the addition of rigid insulation (e.g., polystyrene boards) beneath the exterior treatinent. 
organic and inorganic combustion products have also been identified [National Research Council (NRC) 1981a], but indoor concentrations of these pollutants were not estimated in this assessment.

Because of the nature of the sources of pollutants produced by combustion, the following assumptions were made to determine the source terms for combustion pollutants:

- The typical smoker smokes an average of 2 cigarettes per hour or 31 cigarettes over the course of 16 waking hours a day (NRC 1981a).

- The number of smokers in a residence was 0 (minimum vaiue), 1 (middie or typical value), and 2 (maximum value).

- If one occupant smokes, that occupant is in the residence $80 \%$ of his/her waking hours and smokes 25 cigarettes indoors. The second smoking occupant is in the residential unit $40 \%$ of his/her waking hours and smokes an additional 12 cigarettes indoors.

- Gas stove range-top burners are used an average of $2 \mathrm{~h}$ per day. Gas ovens are used an average i h per day.

- Gas furnaces and hot water heaters are vented directly to the outdoors.

\subsubsection{Resuits of Indoor Air Quality Simulations}

The discussion of the results of the IAQ simulations begins with a brief review of the character of each pollutant, followed by information on its associated health impacts. The indoor concentrations conputed for each of the three residential units are then presented. Each subsection ends with findings of IAQ impacts based on the estimated values of indoor pollutant concentrations. The incremental changes in pollutant concentrations upon which the findings are based are presented in a series of tables (one for each location).

Due to the assumptions outlined previously, no changes in the concentrations of poliutants emanating from sources other than the building materials affected by the voluntary standard would be expected to occur. Sirght changes could occur, however, if the VOLRES standard were developed under tight 
construction requirements, and the baseline case uses the normal construction approach. These worst case results are discussed below.

\subsubsection{Worst-Case Assumptions}

The worst-case assumptions were tested by simulating the change in the prototype of a single-family, electrically heated house with a crawl space located in Fort Worth, Texas. This particular case was used as a test of the worst-case assumptions because it produced one of the largest incremental increases in insulation material and consequently of formaldehyde levels, of a 17 of those modeled in the initial comparison. To model the worst case, the infiltration in the proposed voluntary standard version of the prototype home was reduced to $0.40 \mathrm{ACH}$ ("tight construction"). Pollutant levels were then simulated in the IAQ model. The air change rate in the baseline home remained at $0.52 \mathrm{ACH}$ ("normal construction"). The results for the six pollutants of interest are sumarized in Table 3.2. The decrease in the air change rate in the prototype that meets the proposed standard triggered slight increases in the concentrations of radon and combusted pollutants.

Estimated formaldehyde concentrations increase appreciably, however, in the worst case (normal baseline to tight standard prototypes). This increase is a result of both the decrease in natural infiltration and the increase in the mass of insulation materials in the proposed standard prototype. Nevertheless, the resulting levels are still below the threshold of sensitivity for most individuals.

TABLE 3.2. Summary of Incremental Changes in Indoor Air Quality for the Worst-Case Assumptions (Single-Family Residences)

\begin{tabular}{|c|c|c|c|}
\hline Poilutant (Units) & Low & Typical & High \\
\hline Radon $(p C i / 1)$ & 0.009 & 0.031 & 0.891 \\
\hline Particulates $(\mu g / п 3)$ & 0.000 & 0.028 & 0.041 \\
\hline $\mathrm{co}(\mathrm{mg} / \mathrm{m} 3)$ & 0.000 & 0.223 & 0.328 \\
\hline $\mathrm{CO}_{2}(\mathrm{mg} / \mathrm{m} 3)$ & 265.4 & 265.6 & 265.7 \\
\hline Nox ()$g / n 3)$ & 0.0000 & 0.0001 & 0.0003 \\
\hline Forma1dehyde $(\mu g / m 3)$ & 21.7 & 60.4 & 170.1 \\
\hline
\end{tabular}


Combustion pollutant increases are directly related to the change in ACH. Although the model predicted slight increases in the radon and formaldehyde concentrations due to decreased infiltration, the actual change is dependent on other factors besides infiltration that are less understood and more difficult to predict. The discussion of pollutant behavior in the expected case (i.e., no change in $A C H$ ) in Section 3.3.3.2 provides some perspective on the values shown in Table 3.2 .

\subsubsection{Particulate Matter}

The discussion of particulates is limited to suspended particulates created by combustion. Although varying amounts of dust may be present in residential structures as a result of physical activity in the building, these particulates generally are large enough to remain suspended only temporarily before they are mechanically filtered out by central ventilation filters. Regardless of the source of suspended particulates in a building, either the total suspended particulate (TSP) levels can be examined in an analysis such as this, or only the respirable suspended particulate (RSP) portion. This report focuses on RSP levels by assuming that particles larger than 3.5 micrometers (uri) are present only on a very short-term basis in most structures before they settle out of the air or are filtered out.

Emission rates of RSPs from tobacco smoking are estinated to be 10.8 milligrams (ng) per cigarette smoked (Girman et a1. 1982), or about $335 \mathrm{mg}$ of RSP per smoker per day. For this analysis, the enission rate of RSP uses an average rate of RSP from each cigarette snoked and assumes the previously specified number of occupancy hours per day and a smoker population of 0 , 1 , or 2 (low, nedium, or high).

Health Impacts. The health impacts caused by particulate matter depend to some extent on the sensitivity of the exposed individual. Studies based on low levels of particulate matter suggest that children, asthmatics, smokers, obligatory mouth breathers, and persons with pneumoconiosis or influenza may be at higher risk to deteriorating respiratory functions. Children may also show symptomatic irritation. A study by Lawther, Walier and Henderson (1970) showed likely short-term aggravation of bronchitis at 250 to $500 \mu \mathrm{g} / \mathrm{m}^{3}$ measured by the British Smoke (BS) method. Lunn, Knowelden and Handyside (1967) showed that 
decreased lung function and increased acute respiratory disease in children may occur from long-term exposure to particulate matter below $230 \mathrm{\mu g} / \mathrm{m}^{3}$ of $\mathrm{BS}$. Bouhuys, Beck and Schoenberg (1978) showed that decreased lung function in adults may occur at long-term particulate levels as low as 130 to $180 \mu \mathrm{g} / \mathrm{m}^{3}$ of TSP, and Bouhuys, Beck and Schoenberg (1978) and Ferris et a1. (1973) showed that some risk of increased respiratory disease and/or symptoms in adults may exist from long-term levels of 110 to $180 \mu \mathrm{g} / \mathrm{m}$ of TSP. Appendix D provides more information on the health effects of particulate matter and suggests that current studies do not support health risks of consequences below $55 \mu \mathrm{g} / \mathrm{m}^{3}$ of particles capable of penetrating the thoracic regions of the lungs. Thoracic particles (TP) are defined as particle size less than a nominal $10{ }_{14} \mathrm{~m}$ [U.S. Environmental Protection Agency (EPA) 1982].

Expected Inpact of the Proposed Voluntary Standard. Tables 3.3a through $3.3 \mathrm{j}$ show the incremental changes in concentration levels of particulate natter based on 0, 1, or 2 snokers in the residence and either a gas-fueled cook stove and oven or an electric stove and oven. As the sources for particulate matter are related to occupant behavior, which did not change, the increnental changes as a result of the proposed voluntary standard are zero for all house types and locations when ACH is held constant.

Findings. Implementation of the proposed voluntary standard is expected to have no effect on the levels of particulate matter in residences and no effect on hearth risks.

\section{Carbon Monoxide}

The major sources of carbon monoxide (CO) analyzed in this assessment are gas cooking appliances and occupant smokers. Cooking over a gas burner is expected to release from 200 to $1800 \mathrm{mg}$ of $c 0$ per burner-hour (Cole et al. 1983). C0 is released at a higher rate fron gas ovens [1300 to $3000 \mathrm{mg}$ per oven-hour (NRC 1981a)]. In calculating the CO concentration level for the residential units, a cook stove gas burner is assumed to be used an average of $2 \mathrm{~h}$ per day and the oven is assumed to be used $1 \mathrm{~h}$ per day. Cigarette smoking is a second source of residential indoor 60 . For each cigarette snoked, 105 mg of $\mathrm{CO}$ is released from sidestream and mainstrean snoke (NRC 1981a). Smokers are 
IABLE 3.3a Summary of Incremental Changes in Pollutant Levels from the Base Code to the Proposed Voluntary Standard for Aibany

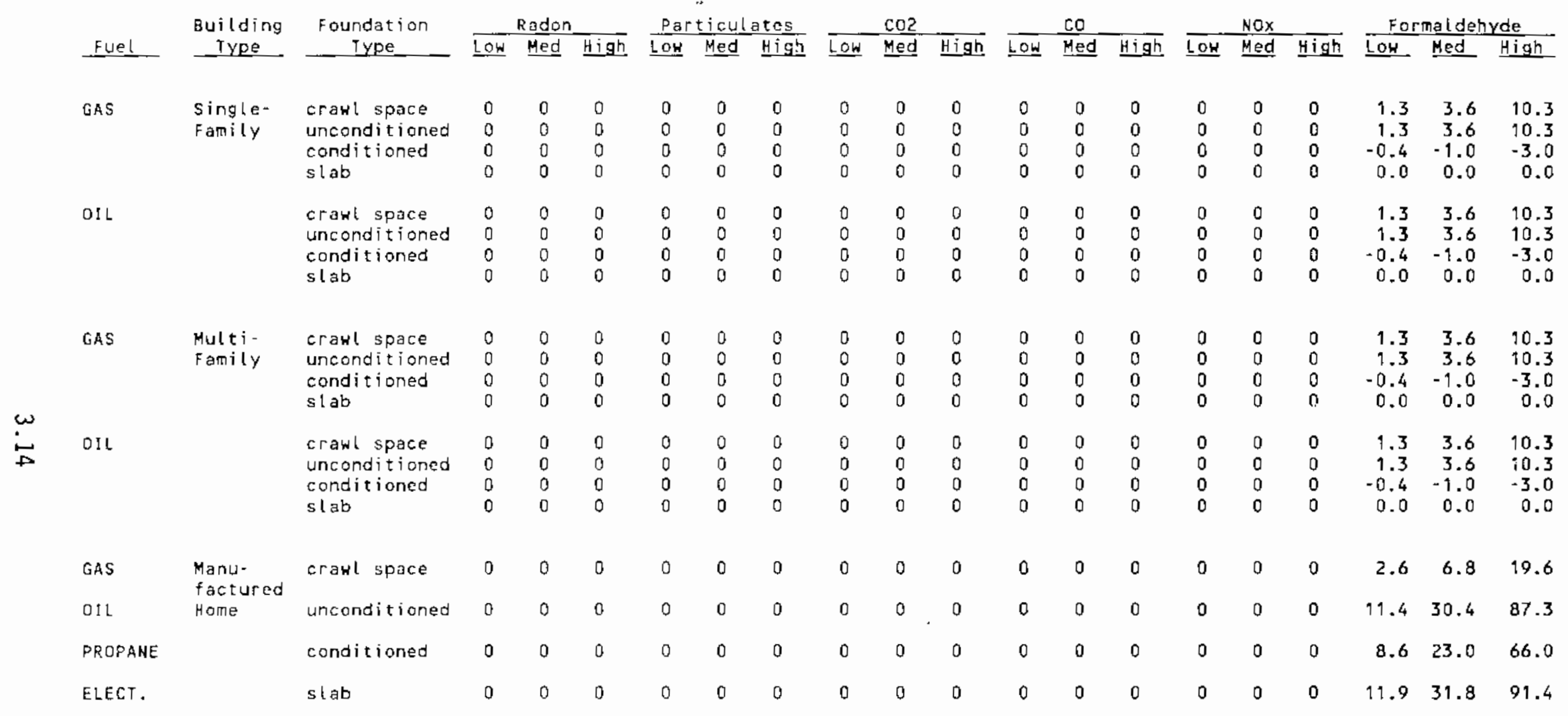


TABLE 3.3b Summary of Incremental Changes in Pollutant Levels from the Base Code to the Proposed Voluntary Standard for At lanta

\begin{tabular}{|c|c|c|c|c|c|c|c|c|c|c|c|c|c|c|c|c|c|c|c|c|}
\hline \multirow[b]{2}{*}{ Fuel } & \multirow{2}{*}{$\begin{array}{l}\text { Building } \\
\text { - Iype }\end{array}$} & \multirow{2}{*}{$\begin{array}{c}\text { Foundation } \\
\text { Type }\end{array}$} & \multicolumn{3}{|c|}{ Radon } & \multicolumn{3}{|c|}{ Particulates } & \multicolumn{3}{|c|}{$\mathrm{CO}$} & \multicolumn{3}{|c|}{ co } & \multicolumn{3}{|c|}{ NOX } & \multicolumn{3}{|c|}{ Formaldehyde } \\
\hline & & & Low & Med & High & LOH & Med & High & Low & Med & High & 애 & Med & High & LOH & Med & High & Lon & Med & High \\
\hline GAS & $\begin{array}{l}\text { Single- } \\
\text { Family }\end{array}$ & $\begin{array}{l}\text { crasl space } \\
\text { unconditioned } \\
\text { condit ioned } \\
\text { siab }\end{array}$ & $\begin{array}{l}0 \\
0 \\
0 \\
0\end{array}$ & $\begin{array}{l}0 \\
0 \\
0 \\
0\end{array}$ & $\begin{array}{l}0 \\
0 \\
0 \\
0\end{array}$ & $\begin{array}{l}0 \\
0 \\
0 \\
0\end{array}$ & $\begin{array}{l}0 \\
0 \\
0 \\
0\end{array}$ & $\begin{array}{l}0 \\
0 \\
0 \\
0\end{array}$ & $\begin{array}{l}0 \\
0 \\
0 \\
0\end{array}$ & $\begin{array}{l}0 \\
0 \\
0 \\
0\end{array}$ & $\begin{array}{l}0 \\
0 \\
0 \\
0\end{array}$ & $\begin{array}{l}0 \\
0 \\
0 \\
0\end{array}$ & $\begin{array}{l}0 \\
0 \\
0 \\
0\end{array}$ & $\begin{array}{l}0 \\
0 \\
0 \\
0\end{array}$ & $\begin{array}{l}0 \\
0 \\
0 \\
0\end{array}$ & $\begin{array}{l}0 \\
0 \\
0 \\
0\end{array}$ & $\begin{array}{l}0 \\
0 \\
0 \\
0\end{array}$ & $\begin{array}{l}5.9 \\
4.8 \\
4.8 \\
0.0\end{array}$ & $\begin{array}{r}15.8 \\
12.8 \\
12.8 \\
0.0\end{array}$ & $\begin{array}{r}45.5 \\
36.9 \\
36.9 \\
0.0\end{array}$ \\
\hline ELECT. & & $\begin{array}{l}\text { crawl space } \\
\text { unconditioned } \\
\text { conditioned } \\
\text { slab }\end{array}$ & $\begin{array}{l}0 \\
0 \\
0 \\
0\end{array}$ & $\begin{array}{l}0 \\
0 \\
0 \\
0\end{array}$ & $\begin{array}{l}0 \\
0 \\
0 \\
0\end{array}$ & $\begin{array}{l}0 \\
0 \\
0 \\
0\end{array}$ & $\begin{array}{l}0 \\
0 \\
0 \\
0\end{array}$ & $\begin{array}{l}0 \\
0 \\
0 \\
0\end{array}$ & $\begin{array}{l}0 \\
0 \\
0 \\
0\end{array}$ & $\begin{array}{l}0 \\
0 \\
0 \\
0\end{array}$ & $\begin{array}{l}0 \\
0 \\
0 \\
0\end{array}$ & $\begin{array}{l}0 \\
0 \\
0 \\
0\end{array}$ & $\begin{array}{l}0 \\
0 \\
0 \\
0\end{array}$ & $\begin{array}{l}0 \\
0 \\
0 \\
0\end{array}$ & $\begin{array}{l}0 \\
0 \\
0 \\
0\end{array}$ & $\begin{array}{l}0 \\
0 \\
0 \\
0\end{array}$ & $\begin{array}{l}0 \\
0 \\
0 \\
0\end{array}$ & $\begin{array}{l}12.8 \\
12.8 \\
10.7 \\
10.4\end{array}$ & $\begin{array}{l}34.2 \\
34.2 \\
28.6 \\
27.9\end{array}$ & $\begin{array}{l}98.2 \\
98.2 \\
82.3 \\
80.7\end{array}$ \\
\hline HP & & $\begin{array}{l}\text { crawl space } \\
\text { unconditioned } \\
\text { conditioned } \\
\text { slab }\end{array}$ & $\begin{array}{l}0 \\
0 \\
0 \\
0\end{array}$ & $\begin{array}{l}0 \\
0 \\
0 \\
0\end{array}$ & $\begin{array}{l}0 \\
0 \\
0 \\
0\end{array}$ & $\begin{array}{l}0 \\
0 \\
0 \\
0\end{array}$ & $\begin{array}{l}0 \\
0 \\
0 \\
0\end{array}$ & $\begin{array}{l}0 \\
0 \\
0 \\
0\end{array}$ & $\begin{array}{l}0 \\
0 \\
0 \\
0\end{array}$ & $\begin{array}{l}0 \\
0 \\
0 \\
0\end{array}$ & $\begin{array}{l}0 \\
0 \\
0 \\
0\end{array}$ & $\begin{array}{l}0 \\
0 \\
0 \\
0\end{array}$ & $\begin{array}{l}0 \\
0 \\
0 \\
0\end{array}$ & $\begin{array}{l}0 \\
0 \\
0 \\
0\end{array}$ & $\begin{array}{l}0 \\
0 \\
0 \\
0\end{array}$ & $\begin{array}{l}0 \\
0 \\
0 \\
0\end{array}$ & $\begin{array}{l}0 \\
0 \\
0 \\
0\end{array}$ & $\begin{array}{l}9.2 \\
6.8 \\
7.2 \\
6.8\end{array}$ & $\begin{array}{l}24.6 \\
18.1 \\
19.1 \\
18.1\end{array}$ & $\begin{array}{l}70.8 \\
52.0 \\
54.9 \\
52.0\end{array}$ \\
\hline $\begin{array}{l}\omega \\
\omega \\
\omega\end{array}$ & $\begin{array}{l}\text { Multi- } \\
\text { Family }\end{array}$ & $\begin{array}{l}\text { craul space } \\
\text { unconditioned } \\
\text { condit ioned } \\
\text { slab }\end{array}$ & $\begin{array}{l}0 \\
0 \\
0 \\
0\end{array}$ & $\begin{array}{l}0 \\
0 \\
0 \\
0\end{array}$ & $\begin{array}{l}0 \\
0 \\
0 \\
0\end{array}$ & $\begin{array}{l}0 \\
0 \\
0 \\
0\end{array}$ & $\begin{array}{l}0 \\
0 \\
0 \\
0\end{array}$ & $\begin{array}{l}0 \\
0 \\
0 \\
0\end{array}$ & $\begin{array}{l}0 \\
0 \\
0 \\
0\end{array}$ & $\begin{array}{l}0 \\
0 \\
0 \\
0\end{array}$ & $\begin{array}{l}0 \\
0 \\
0 \\
0\end{array}$ & $\begin{array}{l}0 \\
0 \\
0 \\
0\end{array}$ & $\begin{array}{l}0 \\
0 \\
0 \\
0\end{array}$ & $\begin{array}{l}0 \\
0 \\
0 \\
0\end{array}$ & $\begin{array}{l}0 \\
0 \\
0 \\
0\end{array}$ & $\begin{array}{l}0 \\
0 \\
0 \\
0\end{array}$ & $\begin{array}{l}0 \\
0 \\
0 \\
0\end{array}$ & $\begin{array}{r}0.0 \\
-1.6 \\
0.1 \\
0.0\end{array}$ & $\begin{array}{r}0.0 \\
-4.2 \\
0.3 \\
0.0\end{array}$ & $\begin{array}{r}0.0 \\
-12.0 \\
0.9 \\
0.0\end{array}$ \\
\hline ELECT. & & $\begin{array}{l}\text { crayl space } \\
\text { uncondi tioned } \\
\text { condit ioned } \\
\text { slab }\end{array}$ & $\begin{array}{l}0 \\
0 \\
0 \\
0\end{array}$ & $\begin{array}{l}0 \\
0 \\
0 \\
0\end{array}$ & $\begin{array}{l}0 \\
0 \\
0 \\
0\end{array}$ & $\begin{array}{l}0 \\
0 \\
0 \\
0\end{array}$ & $\begin{array}{l}0 \\
0 \\
0 \\
0\end{array}$ & $\begin{array}{l}0 \\
0 \\
0 \\
0\end{array}$ & $\begin{array}{l}0 \\
0 \\
0 \\
0\end{array}$ & $\begin{array}{l}0 \\
0 \\
0 \\
0\end{array}$ & $\begin{array}{l}0 \\
0 \\
0 \\
0\end{array}$ & $\begin{array}{l}0 \\
0 \\
0 \\
0\end{array}$ & $\begin{array}{l}0 \\
0 \\
0 \\
0\end{array}$ & $\begin{array}{l}0 \\
0 \\
0 \\
0\end{array}$ & $\begin{array}{l}0 \\
0 \\
0 \\
0\end{array}$ & $\begin{array}{l}0 \\
0 \\
0 \\
0\end{array}$ & $\begin{array}{l}0 \\
0 \\
0 \\
0\end{array}$ & $\begin{array}{l}7.2 \\
7.2 \\
5.0 \\
4.8\end{array}$ & $\begin{array}{l}19.3 \\
19.3 \\
13.3 \\
12.9\end{array}$ & $\begin{array}{l}55.4 \\
55.4 \\
38.4 \\
37.0\end{array}$ \\
\hline HP & & $\begin{array}{l}\text { crawl space } \\
\text { unconditioned } \\
\text { condit ioned } \\
\text { slab }\end{array}$ & $\begin{array}{l}0 \\
0 \\
0 \\
0\end{array}$ & $\begin{array}{l}0 \\
0 \\
0 \\
0\end{array}$ & $\begin{array}{l}0 \\
0 \\
0 \\
0\end{array}$ & $\begin{array}{l}0 \\
0 \\
0 \\
0\end{array}$ & $\begin{array}{l}0 \\
0 \\
0 \\
0\end{array}$ & $\begin{array}{l}0 \\
0 \\
0 \\
0\end{array}$ & $\begin{array}{l}0 \\
0 \\
0 \\
0\end{array}$ & $\begin{array}{l}0 \\
0 \\
0 \\
0\end{array}$ & $\begin{array}{l}0 \\
0 \\
0 \\
0\end{array}$ & $\begin{array}{l}0 \\
0 \\
0 \\
0\end{array}$ & $\begin{array}{l}0 \\
0 \\
0 \\
0\end{array}$ & $\begin{array}{l}0 \\
0 \\
0 \\
0\end{array}$ & $\begin{array}{l}0 \\
0 \\
0 \\
0\end{array}$ & $\begin{array}{l}0 \\
0 \\
0 \\
0\end{array}$ & $\begin{array}{l}0 \\
0 \\
0 \\
0\end{array}$ & $\begin{array}{r}0.0 \\
-1.6 \\
0.1 \\
0.0\end{array}$ & $\begin{array}{r}0.0 \\
-4.2 \\
0.3 \\
0.0\end{array}$ & $\begin{array}{r}0.0 \\
-12.0 \\
0.9 \\
0.0\end{array}$ \\
\hline GAS & $\begin{array}{l}\text { Manu- } \\
\text { factured }\end{array}$ & crawl space & 0 & 0 & 0 & 0 & D & 0 & 0 & 0 & 0 & 0 & 0 & 0 & 0 & 0 & 0 & 4.8 & 12.9 & 37.0 \\
\hline OIL & Home & crawl space & D & 0 & 0 & 0 & 0 & 0 & 0 & 0 & 0 & 0 & 0 & 0 & 0 & 0 & 0 & 14.2 & 38.0 & 109.2 \\
\hline PROPANE & & crawl space & 0 & 0 & 0 & 0 & 0 & 0 & 0 & 0 & 0 & 0 & 0 & 0 & 0 & 0 & 0 & 7.1 & 78.8 & 54.1 \\
\hline
\end{tabular}


IABLE 3.3C Summary of Incremental Changes in Pollutant Levels from the Base Code to the Proposed Voluntary Standard for Denver

\begin{tabular}{|c|c|c|c|c|c|c|c|c|c|c|c|c|c|c|c|c|c|c|c|c|}
\hline \multirow[b]{2}{*}{ Fuel } & \multirow{2}{*}{$\begin{array}{l}\text { Building } \\
\text { Type } \\
\end{array}$} & \multirow{2}{*}{$\begin{array}{c}\text { Foundation } \\
\text { Type }\end{array}$} & \multicolumn{3}{|c|}{ Radon } & \multicolumn{3}{|c|}{ Particulates } & \multicolumn{3}{|c|}{$\mathrm{co2}$} & \multicolumn{3}{|c|}{$\mathrm{CO}$} & \multicolumn{3}{|c|}{ NOXX } & \multicolumn{3}{|c|}{ Formal dehyde } \\
\hline & & & 는 & Med & High & LOH & Med & High & $\mathrm{EOH}$ & Med & High & LOW & Med & High & LOH & Med & High & LOW & Med & High \\
\hline GAS & $\begin{array}{l}\text { Single- } \\
\text { Family }\end{array}$ & $\begin{array}{l}\text { crawl space } \\
\text { unconditioned } \\
\text { conditioned } \\
\text { slab }\end{array}$ & $\begin{array}{l}0 \\
0 \\
0 \\
0\end{array}$ & $\begin{array}{l}0 \\
0 \\
0 \\
0\end{array}$ & $\begin{array}{l}0 \\
0 \\
0 \\
0\end{array}$ & $\begin{array}{l}0 \\
0 \\
0 \\
0\end{array}$ & $\begin{array}{l}0 \\
0 \\
0 \\
0\end{array}$ & $\begin{array}{l}0 \\
0 \\
0 \\
0\end{array}$ & $\begin{array}{l}0 \\
0 \\
0 \\
0\end{array}$ & $\begin{array}{l}0 \\
0 \\
0 \\
0\end{array}$ & $\begin{array}{l}0 \\
0 \\
0 \\
0\end{array}$ & $\begin{array}{l}0 \\
0 \\
0 \\
0\end{array}$ & $\begin{array}{l}0 \\
0 \\
0 \\
0\end{array}$ & $\begin{array}{l}0 \\
0 \\
0 \\
0\end{array}$ & $\begin{array}{l}0 \\
0 \\
0 \\
0\end{array}$ & $\begin{array}{l}0 \\
0 \\
0 \\
0\end{array}$ & $\begin{array}{l}0 \\
0 \\
0 \\
0\end{array}$ & $\begin{array}{l}3.9 \\
5.4 \\
4.3 \\
3.9\end{array}$ & $\begin{array}{l}10.3 \\
14.4 \\
11.5 \\
10.5\end{array}$ & $\begin{array}{l}29.5 \\
41.5 \\
33.0 \\
30.3\end{array}$ \\
\hline ELECT. & & $\begin{array}{l}\text { crawl space } \\
\text { unconditioned } \\
\text { conditioned } \\
\text { slab }\end{array}$ & $\begin{array}{l}0 \\
0 \\
0 \\
0\end{array}$ & $\begin{array}{l}0 \\
0 \\
0 \\
0\end{array}$ & $\begin{array}{l}0 \\
0 \\
0 \\
0\end{array}$ & $\begin{array}{l}0 \\
0 \\
0 \\
0\end{array}$ & $\begin{array}{l}0 \\
0 \\
0 \\
0\end{array}$ & $\begin{array}{l}0 \\
0 \\
0 \\
0\end{array}$ & $\begin{array}{l}0 \\
0 \\
0 \\
0\end{array}$ & $\begin{array}{l}0 \\
0 \\
0 \\
0\end{array}$ & $\begin{array}{l}0 \\
0 \\
0 \\
0\end{array}$ & $\begin{array}{l}0 \\
0 \\
0 \\
0\end{array}$ & $\begin{array}{l}0 \\
0 \\
0 \\
0\end{array}$ & $\begin{array}{l}0 \\
0 \\
0 \\
0\end{array}$ & $\begin{array}{l}0 \\
0 \\
0 \\
0\end{array}$ & $\begin{array}{l}0 \\
0 \\
0 \\
0\end{array}$ & $\begin{array}{l}0 \\
0 \\
0 \\
0\end{array}$ & $\begin{array}{l}6.1 \\
7.9 \\
4.7 \\
4.0\end{array}$ & $\begin{array}{l}16.2 \\
21.0 \\
12.7 \\
10.8\end{array}$ & $\begin{array}{l}46.6 \\
60.3 \\
36.4 \\
31.0\end{array}$ \\
\hline HP & & $\begin{array}{l}\text { crawl space } \\
\text { unconditioned } \\
\text { conditioned } \\
\text { slab }\end{array}$ & $\begin{array}{l}0 \\
0 \\
0 \\
0\end{array}$ & $\begin{array}{l}0 \\
0 \\
0 \\
0\end{array}$ & $\begin{array}{l}0 \\
0 \\
0 \\
0\end{array}$ & $\begin{array}{l}0 \\
0 \\
0 \\
0\end{array}$ & $\begin{array}{l}0 \\
0 \\
0 \\
0\end{array}$ & $\begin{array}{l}0 \\
0 \\
0 \\
0\end{array}$ & $\begin{array}{l}0 \\
0 \\
0 \\
0\end{array}$ & $\begin{array}{l}0 \\
0 \\
0 \\
0\end{array}$ & $\begin{array}{l}0 \\
0 \\
0 \\
0\end{array}$ & $\begin{array}{l}0 \\
0 \\
0 \\
0\end{array}$ & $\begin{array}{l}0 \\
0 \\
0 \\
0\end{array}$ & $\begin{array}{l}0 \\
0 \\
0 \\
0\end{array}$ & $\begin{array}{l}0 \\
0 \\
0 \\
0\end{array}$ & $\begin{array}{l}0 \\
0 \\
0 \\
0\end{array}$ & $\begin{array}{l}0 \\
0 \\
0 \\
0\end{array}$ & $\begin{array}{l}6.1 \\
5.4 \\
4.3 \\
3.9\end{array}$ & $\begin{array}{l}16.2 \\
14.4 \\
11.5 \\
10.5\end{array}$ & $\begin{array}{l}46.6 \\
41.5 \\
33.0 \\
30.3\end{array}$ \\
\hline GAS & $\begin{array}{l}\text { Multi - } \\
\text { Family }\end{array}$ & $\begin{array}{l}\text { crawl space } \\
\text { unconditioned } \\
\text { conditioned } \\
\text { slab }\end{array}$ & $\begin{array}{l}0 \\
0 \\
0 \\
0\end{array}$ & $\begin{array}{l}0 \\
0 \\
0 \\
0\end{array}$ & $\begin{array}{l}0 \\
0 \\
0 \\
0\end{array}$ & $\begin{array}{l}0 \\
0 \\
0 \\
0\end{array}$ & $\begin{array}{l}0 \\
0 \\
0 \\
0\end{array}$ & $\begin{array}{l}0 \\
0 \\
0 \\
0\end{array}$ & $\begin{array}{l}0 \\
0 \\
0 \\
0\end{array}$ & $\begin{array}{l}0 \\
0 \\
0 \\
0\end{array}$ & $\begin{array}{l}0 \\
0 \\
0 \\
0\end{array}$ & $\begin{array}{l}0 \\
0 \\
0 \\
0\end{array}$ & $\begin{array}{l}0 \\
0 \\
0 \\
0\end{array}$ & $\begin{array}{l}0 \\
0 \\
0 \\
0\end{array}$ & $\begin{array}{l}0 \\
0 \\
0 \\
0\end{array}$ & $\begin{array}{l}0 \\
0 \\
0 \\
0\end{array}$ & $\begin{array}{l}0 \\
0 \\
0 \\
0\end{array}$ & $\begin{array}{l}4.8 \\
6.3 \\
4.9 \\
4.8\end{array}$ & $\begin{array}{l}12.7 \\
16.9 \\
13.0 \\
12.9\end{array}$ & $\begin{array}{l}36.5 \\
48.5 \\
37.4 \\
37.0\end{array}$ \\
\hline ELECT. & & $\begin{array}{l}\text { crawl space } \\
\text { unconditioned } \\
\text { condit ioned } \\
\text { stab }\end{array}$ & $\begin{array}{l}0 \\
0 \\
0 \\
0\end{array}$ & $\begin{array}{l}0 \\
0 \\
0 \\
0\end{array}$ & $\begin{array}{l}0 \\
0 \\
0 \\
0\end{array}$ & $\begin{array}{l}0 \\
0 \\
0 \\
0\end{array}$ & $\begin{array}{l}0 \\
0 \\
0 \\
0\end{array}$ & $\begin{array}{l}0 \\
0 \\
0 \\
0\end{array}$ & $\begin{array}{l}0 \\
0 \\
0 \\
0\end{array}$ & $\begin{array}{l}0 \\
0 \\
0 \\
0\end{array}$ & $\begin{array}{l}0 \\
0 \\
0 \\
0\end{array}$ & $\begin{array}{l}0 \\
0 \\
0 \\
0\end{array}$ & $\begin{array}{l}0 \\
0 \\
0 \\
0\end{array}$ & $\begin{array}{l}0 \\
0 \\
0 \\
0\end{array}$ & $\begin{array}{l}0 \\
0 \\
0 \\
0\end{array}$ & $\begin{array}{l}0 \\
0 \\
0 \\
0\end{array}$ & $\begin{array}{l}0 \\
0 \\
0 \\
0\end{array}$ & $\begin{array}{l}7.0 \\
8.8 \\
5.0 \\
4.9\end{array}$ & $\begin{array}{l}18.7 \\
23.4 \\
13.3 \\
13.0\end{array}$ & $\begin{array}{l}53.6 \\
67.3 \\
38.4 \\
37.4\end{array}$ \\
\hline HP & & $\begin{array}{l}\text { crawl space } \\
\text { unconditioned } \\
\text { conditioned } \\
\text { slab }\end{array}$ & $\begin{array}{l}0 \\
0 \\
0 \\
0\end{array}$ & $\begin{array}{l}0 \\
0 \\
0 \\
0\end{array}$ & $\begin{array}{l}0 \\
0 \\
0 \\
0\end{array}$ & $\begin{array}{l}0 \\
0 \\
0 \\
0\end{array}$ & $\begin{array}{l}0 \\
0 \\
0 \\
0\end{array}$ & $\begin{array}{l}0 \\
0 \\
0 \\
0\end{array}$ & $\begin{array}{l}0 \\
0 \\
0 \\
0\end{array}$ & $\begin{array}{l}0 \\
0 \\
0 \\
0\end{array}$ & $\begin{array}{l}0 \\
0 \\
0 \\
0\end{array}$ & $\begin{array}{l}0 \\
0 \\
0 \\
0\end{array}$ & $\begin{array}{l}0 \\
0 \\
0 \\
0\end{array}$ & $\begin{array}{l}0 \\
0 \\
0 \\
0\end{array}$ & $\begin{array}{l}0 \\
0 \\
0 \\
0\end{array}$ & $\begin{array}{l}0 \\
0 \\
0 \\
0\end{array}$ & $\begin{array}{l}0 \\
0 \\
0 \\
0\end{array}$ & $\begin{array}{l}7.0 \\
6.3 \\
4.9 \\
4.8\end{array}$ & $\begin{array}{l}18.7 \\
16.9 \\
13.0 \\
12.9\end{array}$ & $\begin{array}{l}53.6 \\
48.5 \\
37.4 \\
37.0\end{array}$ \\
\hline GAS & $\begin{array}{l}\text { Manu- } \\
\text { factured }\end{array}$ & crawl space & 0 & 0 & 0 & 0 & 0 & 0 & 0 & 0 & 0 & 0 & 0 & 0 & 0 & 0 & 0 & -6.1 & -96.2 & -46.5 \\
\hline PROPANE & Home & craw! space & 0 & 0 & 0 & 0 & 0 & 0 & 0 & 0 & 0 & 0 & 0 & 0 & 0 & 0 & 0 & -6.1 & -16.2 & -46.5 \\
\hline ELECT. & & crawl space & 0 & 0 & 0 & 0 & 0 & 0 & 0 & 0 & 0 & 0 & 0 & 0 & 0 & 0 & 0 & 4.7 & 12.6 & 36.3 \\
\hline
\end{tabular}


IABLE 3.3d Summary of Incremental Changes in Pollutant Levels from the Base Code to the Proposed Voluntary Standard for Fort Worth

\begin{tabular}{|c|c|c|c|c|c|c|c|c|c|c|c|c|c|c|c|c|c|c|c|c|}
\hline \multirow[b]{2}{*}{ Fuel } & \multirow{2}{*}{$\begin{array}{c}\text { Building } \\
\text { Type } \\
\end{array}$} & \multirow{2}{*}{$\begin{array}{c}\text { Foundation } \\
\text { Type }\end{array}$} & \multicolumn{3}{|c|}{ Radon } & \multicolumn{3}{|c|}{ Particulates } & \multicolumn{3}{|c|}{$\mathrm{CO} 2$} & \multicolumn{3}{|c|}{$\mathrm{Co}$} & \multicolumn{3}{|c|}{ NOX } & \multicolumn{3}{|c|}{ Formaldehyde } \\
\hline & & & LOW & Med & High & Low & Med & $\underline{\mathrm{H} g h}$ & 으므 & Med & High & LOW & Med & High & 으묘 & Med & High & LoW & Med & high \\
\hline GAS & $\begin{array}{l}\text { Single- } \\
\text { Family }\end{array}$ & $\begin{array}{l}\text { crawl space } \\
\text { unconditioned } \\
\text { conditioned } \\
\text { slab }\end{array}$ & $\begin{array}{l}0 \\
0 \\
0 \\
0\end{array}$ & $\begin{array}{l}0 \\
0 \\
0 \\
0\end{array}$ & $\begin{array}{l}0 \\
0 \\
0 \\
0\end{array}$ & $\begin{array}{l}0 \\
0 \\
0 \\
0\end{array}$ & $\begin{array}{l}0 \\
0 \\
0 \\
0\end{array}$ & $\begin{array}{l}0 \\
0 \\
0 \\
0\end{array}$ & $\begin{array}{l}0 \\
0 \\
0 \\
0\end{array}$ & $\begin{array}{l}0 \\
0 \\
0 \\
0\end{array}$ & $\begin{array}{l}0 \\
0 \\
0 \\
0\end{array}$ & $\begin{array}{l}0 \\
0 \\
0 \\
0\end{array}$ & $\begin{array}{l}0 \\
0 \\
0 \\
0\end{array}$ & $\begin{array}{l}0 \\
0 \\
0 \\
0\end{array}$ & $\begin{array}{l}0 \\
0 \\
0 \\
0\end{array}$ & $\begin{array}{l}0 \\
0 \\
0 \\
0\end{array}$ & $\begin{array}{l}0 \\
0 \\
0 \\
0\end{array}$ & $\begin{array}{l}7.6 \\
5.8 \\
5.8 \\
5.8\end{array}$ & $\begin{array}{l}20.3 \\
15.5 \\
15.5 \\
15.5\end{array}$ & $\begin{array}{l}58.3 \\
44.6 \\
44.6 \\
44.6\end{array}$ \\
\hline ELECT. & & $\begin{array}{l}\text { erawl space } \\
\text { unconditioned } \\
\text { conditioned } \\
\text { slab }\end{array}$ & $\begin{array}{l}0 \\
0 \\
0 \\
0\end{array}$ & $\begin{array}{l}0 \\
0 \\
0 \\
0\end{array}$ & $\begin{array}{l}0 \\
0 \\
0 \\
0\end{array}$ & $\begin{array}{l}0 \\
0 \\
0 \\
0\end{array}$ & $\begin{array}{l}0 \\
0 \\
0 \\
0\end{array}$ & $\begin{array}{l}0 \\
0 \\
0 \\
0\end{array}$ & $\begin{array}{l}0 \\
0 \\
0 \\
0\end{array}$ & $\begin{array}{l}0 \\
0 \\
0 \\
0\end{array}$ & $\begin{array}{l}0 \\
0 \\
0 \\
0\end{array}$ & $\begin{array}{l}0 \\
0 \\
0 \\
0\end{array}$ & $\begin{array}{l}0 \\
0 \\
0 \\
0\end{array}$ & $\begin{array}{l}0 \\
0 \\
0 \\
0\end{array}$ & $\begin{array}{l}0 \\
0 \\
0 \\
0\end{array}$ & $\begin{array}{l}0 \\
0 \\
0 \\
0\end{array}$ & $\begin{array}{l}0 \\
0 \\
0 \\
0\end{array}$ & $\begin{array}{l}9.8 \\
9.8 \\
6.2 \\
6.0\end{array}$ & $\begin{array}{l}26.2 \\
26.2 \\
16.5 \\
16.0\end{array}$ & $\begin{array}{l}75.4 \\
75.4 \\
47.5 \\
46.1\end{array}$ \\
\hline HP & & $\begin{array}{l}\text { crawl space } \\
\text { unconditioned } \\
\text { conditioned } \\
\text { slab }\end{array}$ & $\begin{array}{l}0 \\
0 \\
0 \\
0\end{array}$ & $\begin{array}{l}0 \\
0 \\
0 \\
0\end{array}$ & $\begin{array}{l}0 \\
0 \\
0 \\
0\end{array}$ & $\begin{array}{l}0 \\
0 \\
0 \\
0\end{array}$ & $\begin{array}{l}0 \\
0 \\
0 \\
0\end{array}$ & $\begin{array}{l}0 \\
0 \\
0 \\
0\end{array}$ & $\begin{array}{l}0 \\
0 \\
0 \\
0\end{array}$ & $\begin{array}{l}0 \\
0 \\
0 \\
0\end{array}$ & $\begin{array}{l}0 \\
0 \\
0 \\
0\end{array}$ & $\begin{array}{l}0 \\
0 \\
0 \\
0\end{array}$ & $\begin{array}{l}0 \\
0 \\
0 \\
0\end{array}$ & $\begin{array}{l}0 \\
0 \\
0 \\
0\end{array}$ & $\begin{array}{l}0 \\
0 \\
0 \\
0\end{array}$ & $\begin{array}{l}0 \\
0 \\
0 \\
0\end{array}$ & $\begin{array}{l}0 \\
0 \\
0 \\
0\end{array}$ & $\begin{array}{l}3.7 \\
2.8 \\
1.4 \\
1.1\end{array}$ & $\begin{array}{l}9.8 \\
7.4 \\
3.7 \\
2.9\end{array}$ & $\begin{array}{r}28.2 \\
21.4 \\
10.6 \\
8.4\end{array}$ \\
\hline $\begin{array}{l}\omega \\
i \\
\sim\end{array}$ & $\begin{array}{l}\text { Multi- } \\
\text { Family }\end{array}$ & $\begin{array}{l}\text { crawl space } \\
\text { unconditioned } \\
\text { conditioned } \\
\text { slab }\end{array}$ & $\begin{array}{l}0 \\
0 \\
0 \\
0\end{array}$ & $\begin{array}{l}0 \\
0 \\
0 \\
0\end{array}$ & $\begin{array}{l}0 \\
0 \\
0 \\
0\end{array}$ & $\begin{array}{l}0 \\
0 \\
0 \\
0\end{array}$ & $\begin{array}{l}0 \\
0 \\
0 \\
0\end{array}$ & $\begin{array}{l}0 \\
0 \\
0 \\
0\end{array}$ & $\begin{array}{l}0 \\
0 \\
0 \\
0\end{array}$ & $\begin{array}{l}0 \\
0 \\
0 \\
0\end{array}$ & $\begin{array}{l}0 \\
0 \\
0 \\
0\end{array}$ & $\begin{array}{l}0 \\
0 \\
0 \\
0\end{array}$ & $\begin{array}{l}0 \\
0 \\
0 \\
0\end{array}$ & $\begin{array}{l}0 \\
0 \\
0 \\
0\end{array}$ & $\begin{array}{l}0 \\
0 \\
0 \\
0\end{array}$ & $\begin{array}{l}0 \\
0 \\
0 \\
0\end{array}$ & $\begin{array}{l}0 \\
0 \\
0 \\
0\end{array}$ & $\begin{array}{l}8.5 \\
6.7 \\
6.8 \\
6.7\end{array}$ & $\begin{array}{l}22.7 \\
17.9 \\
18.3 \\
17.9\end{array}$ & $\begin{array}{l}65.3 \\
59.6 \\
52.5 \\
51.6\end{array}$ \\
\hline ELECT. & & $\begin{array}{l}\text { craw! space } \\
\text { unconditioned } \\
\text { conditioned } \\
\text { stab }\end{array}$ & $\begin{array}{l}0 \\
0 \\
0 \\
0\end{array}$ & $\begin{array}{l}0 \\
0 \\
0 \\
0\end{array}$ & $\begin{array}{l}0 \\
0 \\
0 \\
0\end{array}$ & $\begin{array}{l}0 \\
0 \\
0 \\
0\end{array}$ & $\begin{array}{l}0 \\
0 \\
0 \\
0\end{array}$ & $\begin{array}{l}0 \\
0 \\
0 \\
0\end{array}$ & $\begin{array}{l}0 \\
0 \\
0 \\
0\end{array}$ & $\begin{array}{l}0 \\
0 \\
0 \\
0\end{array}$ & $\begin{array}{l}0 \\
0 \\
0 \\
0\end{array}$ & $\begin{array}{l}0 \\
0 \\
0 \\
0\end{array}$ & $\begin{array}{l}0 \\
0 \\
0 \\
0\end{array}$ & $\begin{array}{l}0 \\
0 \\
0 \\
0\end{array}$ & $\begin{array}{l}0 \\
0 \\
0 \\
0\end{array}$ & $\begin{array}{l}0 \\
0 \\
0 \\
0\end{array}$ & $\begin{array}{l}0 \\
0 \\
0 \\
0\end{array}$ & $\begin{array}{r}10.7 \\
8.5 \\
7.0 \\
6.8\end{array}$ & $\begin{array}{l}28.7 \\
22.7 \\
18.6 \\
18.1\end{array}$ & $\begin{array}{l}82.4 \\
65.3 \\
53.4 \\
52.0\end{array}$ \\
\hline HP & & $\begin{array}{l}\text { crawl space } \\
\text { unconditioned } \\
\text { conditioned } \\
\text { slab }\end{array}$ & $\begin{array}{l}0 \\
0 \\
0 \\
0\end{array}$ & $\begin{array}{l}0 \\
0 \\
0 \\
0\end{array}$ & $\begin{array}{l}0 \\
0 \\
0 \\
0\end{array}$ & $\begin{array}{l}0 \\
0 \\
0 \\
0\end{array}$ & $\begin{array}{l}0 \\
0 \\
0 \\
0\end{array}$ & $\begin{array}{l}0 \\
0 \\
0 \\
0\end{array}$ & $\begin{array}{l}0 \\
0 \\
0 \\
0\end{array}$ & $\begin{array}{l}0 \\
0 \\
0 \\
0\end{array}$ & $\begin{array}{l}0 \\
0 \\
0 \\
0\end{array}$ & $\begin{array}{l}0 \\
0 \\
0 \\
0\end{array}$ & $\begin{array}{l}0 \\
0 \\
0 \\
0\end{array}$ & $\begin{array}{l}0 \\
0 \\
0 \\
0\end{array}$ & $\begin{array}{l}0 \\
0 \\
0 \\
0\end{array}$ & $\begin{array}{l}0 \\
0 \\
0 \\
0\end{array}$ & $\begin{array}{l}0 \\
0 \\
0 \\
0\end{array}$ & $\begin{array}{l}3.8 \\
2.0 \\
2.1 \\
2.0\end{array}$ & $\begin{array}{r}10.0 \\
5.2 \\
5.6 \\
5.2\end{array}$ & $\begin{array}{l}28.8 \\
15.1 \\
16.0 \\
15.1\end{array}$ \\
\hline GAS & $\begin{array}{l}\text { Manu- } \\
\text { factured }\end{array}$ & crawl space & 0 & 0 & 0 & 0 & 0 & 0 & 0 & 0 & 0 & 0 & 0 & 0 & 0 & 0 & 0 & -1.1 & -3.0 & -8.6 \\
\hline PROPANE & Home & crawl space & 0 & 0 & 0 & 0 & 0 & 0 & 0 & 0 & 0 & 0 & 0 & 0 & 0 & 0 & 0 & 1.1 & 3.0 & 8.6 \\
\hline ELECT. & & crawl space & 0 & 0 & 0 & 0 & 0 & 0 & 0 & 0 & 0 & 0 & 0 & 0 & 0 & 0 & 0 & 8.3 & 22.1 & 63.7 \\
\hline
\end{tabular}


IABLE $3.3 \mathrm{e}$ Summary of Incremental Changes in Pollutant Levels from the Base code to the Proposed Voluntary Standard for "linneapolis

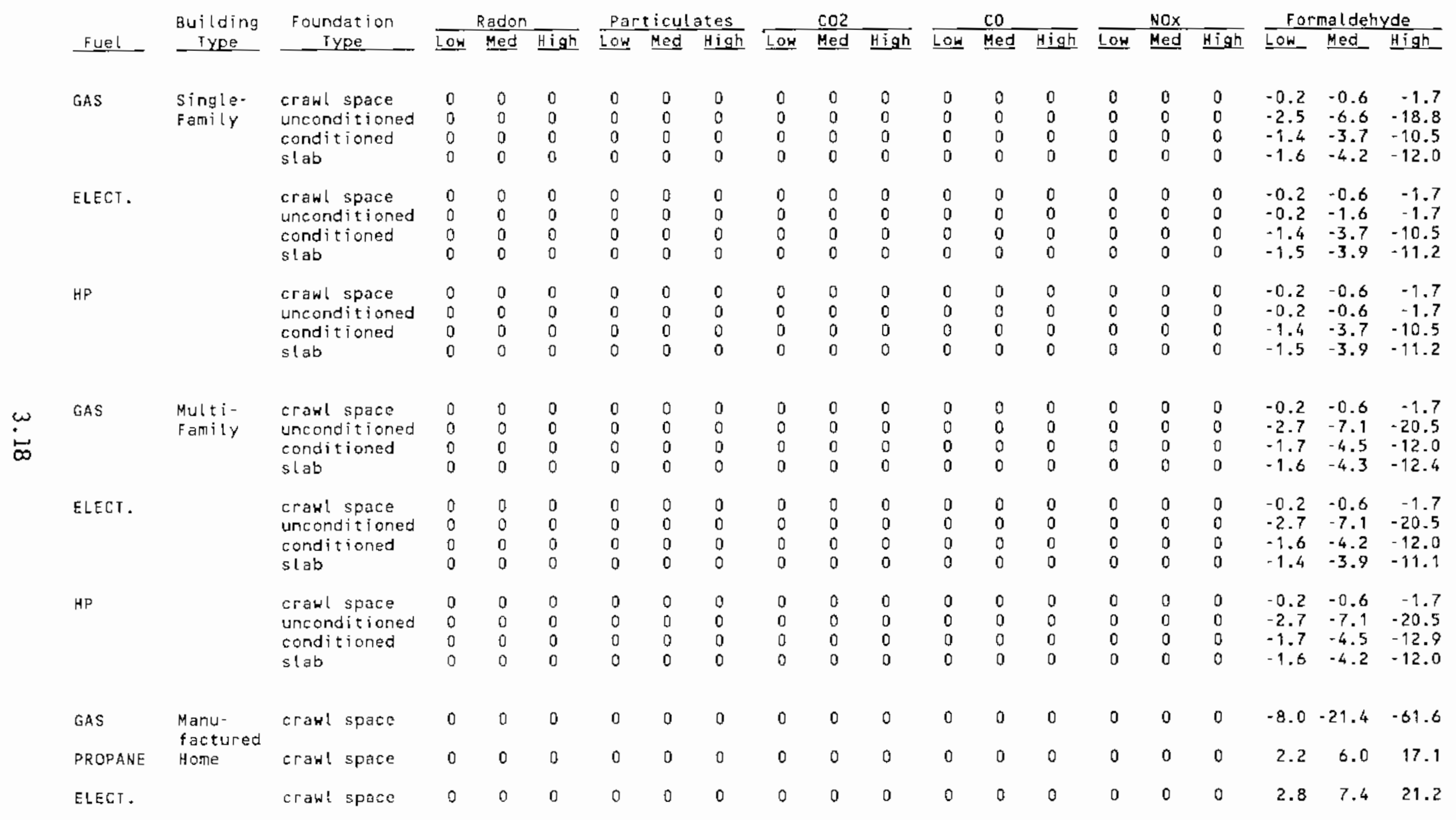


TABLE 3.3f Summary of Incremental Changes in Pollutant Levels from the Base Code to the Proposed Voluntary Standard for Pasadena

\begin{tabular}{|c|c|c|c|c|c|c|c|c|c|c|c|c|c|c|c|c|c|c|c|c|}
\hline \multirow[b]{2}{*}{ Fuel } & \multirow{2}{*}{$\begin{array}{l}\text { 8uilding } \\
\text { Type } \\
\end{array}$} & \multirow{2}{*}{$\begin{array}{c}\text { Foundation } \\
\text { Type }\end{array}$} & \multicolumn{3}{|c|}{ Radon } & \multicolumn{3}{|c|}{ Particulates } & \multicolumn{3}{|c|}{$\operatorname{coz}$} & \multicolumn{3}{|c|}{$\mathrm{CO}$} & \multicolumn{3}{|c|}{ NOX } & \multicolumn{3}{|c|}{ Formaldehyde } \\
\hline & & & LOㅐ & Med & $\underline{\mathrm{High}}$ & LOH & Med & 보은 & L읍 & Med & High & LOH & Med & High & LOW & Med & High & Low & Med & High \\
\hline GAS & $\begin{array}{l}\text { Single- } \\
\text { Family }\end{array}$ & $\begin{array}{l}\text { crawl space } \\
\text { unconditioned } \\
\text { conditioned } \\
\text { slab }\end{array}$ & $\begin{array}{l}0 \\
0 \\
0 \\
0\end{array}$ & $\begin{array}{l}0 \\
0 \\
0 \\
0\end{array}$ & $\begin{array}{l}0 \\
0 \\
0 \\
0\end{array}$ & $\begin{array}{l}0 \\
0 \\
0 \\
0\end{array}$ & $\begin{array}{l}0 \\
0 \\
0 \\
0\end{array}$ & $\begin{array}{l}0 \\
0 \\
0 \\
0\end{array}$ & $\begin{array}{l}0 \\
0 \\
0 \\
0\end{array}$ & $\begin{array}{l}0 \\
0 \\
0 \\
0\end{array}$ & $\begin{array}{l}0 \\
0 \\
0 \\
0\end{array}$ & $\begin{array}{l}0 \\
0 \\
0 \\
0\end{array}$ & $\begin{array}{l}0 \\
0 \\
0 \\
0\end{array}$ & $\begin{array}{l}0 \\
0 \\
0 \\
0\end{array}$ & $\begin{array}{l}0 \\
0 \\
0 \\
0\end{array}$ & $\begin{array}{l}0 \\
0 \\
0 \\
0\end{array}$ & $\begin{array}{l}0 \\
0 \\
0 \\
0\end{array}$ & $\begin{array}{l}5.7 \\
4.1 \\
6.8 \\
6.8\end{array}$ & $\begin{array}{l}15.1 \\
10.9 \\
18.1 \\
18.1\end{array}$ & $\begin{array}{l}43.4 \\
31.4 \\
52.0 \\
52.0\end{array}$ \\
\hline ELECT. & & $\begin{array}{l}\text { crawl space } \\
\text { unconditioned } \\
\text { conditioned } \\
\text { stab }\end{array}$ & $\begin{array}{l}0 \\
0 \\
0 \\
0\end{array}$ & $\begin{array}{l}0 \\
0 \\
0 \\
0\end{array}$ & $\begin{array}{l}0 \\
0 \\
0 \\
0\end{array}$ & $\begin{array}{l}0 \\
0 \\
0 \\
0\end{array}$ & $\begin{array}{l}0 \\
0 \\
0 \\
0\end{array}$ & $\begin{array}{l}0 \\
0 \\
0 \\
0\end{array}$ & $\begin{array}{l}0 \\
0 \\
0 \\
0\end{array}$ & $\begin{array}{l}0 \\
0 \\
0 \\
0\end{array}$ & $\begin{array}{l}0 \\
0 \\
0 \\
0\end{array}$ & $\begin{array}{l}0 \\
0 \\
0 \\
0\end{array}$ & $\begin{array}{l}0 \\
0 \\
0 \\
0\end{array}$ & $\begin{array}{l}0 \\
0 \\
0 \\
0\end{array}$ & $\begin{array}{l}0 \\
0 \\
0 \\
0\end{array}$ & $\begin{array}{l}0 \\
0 \\
0 \\
0\end{array}$ & $\begin{array}{l}0 \\
0 \\
0 \\
0\end{array}$ & $\begin{array}{l}5.9 \\
5.7 \\
7.0 \\
6.9\end{array}$ & $\begin{array}{l}15.7 \\
15.1 \\
18.6 \\
18.3\end{array}$ & $\begin{array}{l}45.1 \\
43.4 \\
53.5 \\
52.7\end{array}$ \\
\hline HP & & $\begin{array}{l}\text { crawl space } \\
\text { unconditioned } \\
\text { conditioned } \\
\text { slab }\end{array}$ & $\begin{array}{l}0 \\
0 \\
0 \\
0\end{array}$ & $\begin{array}{l}0 \\
0 \\
0 \\
0\end{array}$ & $\begin{array}{l}0 \\
0 \\
0 \\
0\end{array}$ & $\begin{array}{l}0 \\
0 \\
0 \\
0\end{array}$ & $\begin{array}{l}0 \\
0 \\
0 \\
0\end{array}$ & $\begin{array}{l}0 \\
0 \\
0 \\
0\end{array}$ & $\begin{array}{l}0 \\
0 \\
0 \\
0\end{array}$ & $\begin{array}{l}0 \\
0 \\
0 \\
0\end{array}$ & $\begin{array}{l}0 \\
0 \\
0 \\
0\end{array}$ & $\begin{array}{l}0 \\
0 \\
0 \\
0\end{array}$ & $\begin{array}{l}0 \\
0 \\
0 \\
0\end{array}$ & $\begin{array}{l}0 \\
0 \\
0 \\
0\end{array}$ & $\begin{array}{l}0 \\
0 \\
0 \\
0\end{array}$ & $\begin{array}{l}0 \\
0 \\
0 \\
0\end{array}$ & $\begin{array}{l}0 \\
0 \\
0 \\
0\end{array}$ & $\begin{array}{l}5.9 \\
4.1 \\
6.8 \\
6.8\end{array}$ & $\begin{array}{l}15.7 \\
10.9 \\
48.1 \\
18.1\end{array}$ & $\begin{array}{l}45.1 \\
31.4 \\
52.0 \\
52.0\end{array}$ \\
\hline $\begin{array}{l}\omega \\
0 \\
0\end{array}$ & $\begin{array}{l}\text { Mutti- } \\
\text { Family }\end{array}$ & $\begin{array}{l}\text { crawl space } \\
\text { unconditioned } \\
\text { conditioned } \\
\text { slab }\end{array}$ & $\begin{array}{l}0 \\
0 \\
0 \\
0\end{array}$ & $\begin{array}{l}0 \\
0 \\
0 \\
0\end{array}$ & $\begin{array}{l}0 \\
0 \\
0 \\
0\end{array}$ & $\begin{array}{l}0 \\
0 \\
0 \\
0\end{array}$ & $\begin{array}{l}0 \\
0 \\
0 \\
0\end{array}$ & $\begin{array}{l}0 \\
0 \\
0 \\
0\end{array}$ & $\begin{array}{l}0 \\
0 \\
0 \\
0\end{array}$ & $\begin{array}{l}0 \\
0 \\
0 \\
0\end{array}$ & $\begin{array}{l}0 \\
0 \\
0 \\
0\end{array}$ & $\begin{array}{l}0 \\
0 \\
0 \\
0\end{array}$ & $\begin{array}{l}0 \\
0 \\
0 \\
0\end{array}$ & $\begin{array}{l}0 \\
0 \\
0 \\
0\end{array}$ & $\begin{array}{l}0 \\
0 \\
0 \\
0\end{array}$ & $\begin{array}{l}0 \\
0 \\
0 \\
0\end{array}$ & $\begin{array}{l}0 \\
0 \\
0 \\
0\end{array}$ & $\begin{array}{r}0.1 \\
-1.5 \\
1.2 \\
1.2\end{array}$ & $\begin{array}{r}0.2 \\
-4.0 \\
3.2 \\
3.2\end{array}$ & $\begin{array}{r}0.6 \\
-11.4 \\
9.1 \\
9.1\end{array}$ \\
\hline ELECT. & & $\begin{array}{l}\text { crawl space } \\
\text { unconditioned } \\
\text { conditioned } \\
\text { slab }\end{array}$ & $\begin{array}{l}0 \\
0 \\
0 \\
0\end{array}$ & $\begin{array}{l}0 \\
0 \\
0 \\
0\end{array}$ & $\begin{array}{l}0 \\
0 \\
0 \\
0\end{array}$ & $\begin{array}{l}0 \\
0 \\
0 \\
0\end{array}$ & $\begin{array}{l}0 \\
0 \\
0 \\
0\end{array}$ & $\begin{array}{l}0 \\
0 \\
0 \\
0\end{array}$ & $\begin{array}{l}0 \\
0 \\
0 \\
0\end{array}$ & $\begin{array}{l}0 \\
0 \\
0 \\
0\end{array}$ & $\begin{array}{l}0 \\
0 \\
0 \\
0\end{array}$ & $\begin{array}{l}0 \\
0 \\
0 \\
0\end{array}$ & $\begin{array}{l}0 \\
0 \\
0 \\
0\end{array}$ & $\begin{array}{l}0 \\
0 \\
0 \\
0\end{array}$ & $\begin{array}{l}0 \\
0 \\
0 \\
0\end{array}$ & $\begin{array}{l}0 \\
0 \\
0 \\
0\end{array}$ & $\begin{array}{l}0 \\
0 \\
0 \\
0\end{array}$ & $\begin{array}{l}5.1 \\
5.1 \\
6.1 \\
6.0\end{array}$ & $\begin{array}{l}13.5 \\
13.5 \\
16.2 \\
15.9\end{array}$ & $\begin{array}{l}38.8 \\
38.8 \\
46.6 \\
45.7\end{array}$ \\
\hline HP & & $\begin{array}{l}\text { crawl space } \\
\text { unconditioned } \\
\text { conditioned } \\
\text { slab }\end{array}$ & $\begin{array}{l}0 \\
0 \\
0 \\
0\end{array}$ & $\begin{array}{l}0 \\
0 \\
0 \\
0\end{array}$ & $\begin{array}{l}0 \\
0 \\
0 \\
0\end{array}$ & $\begin{array}{l}0 \\
0 \\
0 \\
0\end{array}$ & $\begin{array}{l}0 \\
0 \\
0 \\
0\end{array}$ & $\begin{array}{l}0 \\
0 \\
0 \\
0\end{array}$ & $\begin{array}{l}0 \\
0 \\
0 \\
0\end{array}$ & $\begin{array}{l}0 \\
0 \\
0 \\
0\end{array}$ & $\begin{array}{l}0 \\
0 \\
0 \\
0\end{array}$ & $\begin{array}{l}0 \\
0 \\
0 \\
0\end{array}$ & $\begin{array}{l}0 \\
0 \\
0 \\
0\end{array}$ & $\begin{array}{l}0 \\
0 \\
0 \\
0\end{array}$ & $\begin{array}{l}0 \\
0 \\
0 \\
0\end{array}$ & $\begin{array}{l}0 \\
0 \\
0 \\
0\end{array}$ & $\begin{array}{l}0 \\
0 \\
0 \\
0\end{array}$ & $\begin{array}{r}0.1 \\
-1.5 \\
1.2 \\
1.2\end{array}$ & $\begin{array}{r}0.2 \\
-4.0 \\
3.2 \\
3.2\end{array}$ & $\begin{array}{r}0.6 \\
-11.4 \\
9.1 \\
9.1\end{array}$ \\
\hline GAS & $\begin{array}{l}\text { Manu- } \\
\text { factured }\end{array}$ & cranl space & 0 & 0 & 0 & 0 & 0 & 0 & 0 & 0 & 0 & 0 & 0 & 0 & 0 & 0 & 0 & 3.2 & 8.6 & 24.7 \\
\hline PROPANE & Home & crabl space & 0 & 0 & 0 & 0 & 0 & 0 & 0 & 0 & 0 & 0 & 0 & 0 & 0 & 0 & 0 & 5.8 & 15.4 & 44.2 \\
\hline ELECT . & & crawl space & 0 & 0 & 0 & 0 & 0 & 0 & 0 & 0 & 0 & 0 & 0 & 0 & 0 & 0 & 0 & 13.0 & 34.5 & 99.3 \\
\hline
\end{tabular}


TABLE 3.3g Summary of Incremental Changes in Pollutant Leveis from the Base Code to the Proposed Votuntary Standard for Phoenix

\begin{tabular}{|c|c|c|c|c|c|c|c|c|c|c|c|c|c|c|c|c|c|c|c|c|}
\hline \multirow[b]{2}{*}{ Fuel } & \multirow{2}{*}{$\begin{array}{l}\text { Building } \\
\text { Type } \\
\end{array}$} & \multirow{2}{*}{$\begin{array}{c}\text { Foundation } \\
\text { Type }\end{array}$} & \multicolumn{3}{|c|}{ Radon } & \multicolumn{3}{|c|}{ Particulates } & \multicolumn{3}{|c|}{$\mathrm{CO} 2$} & \multicolumn{3}{|c|}{$\mathrm{CO}$} & \multicolumn{3}{|c|}{ NOX } & \multicolumn{3}{|c|}{ Formaldehyde } \\
\hline & & & LOW & Med & High & Low & Med & High & $\underline{L O H}$ & Med & High & LOW & Med & High & $\overline{\mathrm{LOH}}$ & Med & ㅂigh & LOW & Med & High \\
\hline GAS & $\begin{array}{l}\text { Single- } \\
\text { Family }\end{array}$ & $\begin{array}{l}\text { crawl space } \\
\text { uncorditioned } \\
\text { conditiored } \\
\text { slab }\end{array}$ & $\begin{array}{l}0 \\
0 \\
0 \\
0\end{array}$ & $\begin{array}{l}0 \\
0 \\
0 \\
0\end{array}$ & $\begin{array}{l}0 \\
0 \\
0 \\
0\end{array}$ & $\begin{array}{l}0 \\
0 \\
0 \\
0\end{array}$ & $\begin{array}{l}0 \\
0 \\
0 \\
0\end{array}$ & $\begin{array}{l}0 \\
0 \\
0 \\
0\end{array}$ & $\begin{array}{l}0 \\
0 \\
0 \\
0\end{array}$ & $\begin{array}{l}0 \\
0 \\
0 \\
0\end{array}$ & $\begin{array}{l}0 \\
0 \\
0 \\
0\end{array}$ & $\begin{array}{l}0 \\
0 \\
0 \\
0\end{array}$ & $\begin{array}{l}0 \\
0 \\
0 \\
0\end{array}$ & $\begin{array}{l}0 \\
0 \\
0 \\
0\end{array}$ & $\begin{array}{l}0 \\
0 \\
0 \\
0\end{array}$ & $\begin{array}{l}0 \\
0 \\
0 \\
0\end{array}$ & $\begin{array}{l}0 \\
0 \\
0 \\
0\end{array}$ & $\begin{array}{l}-6.6 \\
-6.8 \\
-6.6 \\
-6.8\end{array}$ & $\begin{array}{l}-17.5 \\
-18.1 \\
-17.6 \\
-18.1\end{array}$ & $\begin{array}{l}-50.3 \\
-52.0 \\
-50.5 \\
-52.0\end{array}$ \\
\hline ELECT. & & $\begin{array}{l}\text { Erawl space } \\
\text { unconditioned } \\
\text { conditioned } \\
\text { slab }\end{array}$ & $\begin{array}{l}0 \\
0 \\
0 \\
0\end{array}$ & $\begin{array}{l}0 \\
0 \\
0 \\
0\end{array}$ & $\begin{array}{l}0 \\
0 \\
0 \\
0\end{array}$ & $\begin{array}{l}0 \\
0 \\
0 \\
0\end{array}$ & $\begin{array}{l}0 \\
0 \\
0 \\
0\end{array}$ & $\begin{array}{l}0 \\
0 \\
0 \\
0\end{array}$ & $\begin{array}{l}0 \\
0 \\
0 \\
0\end{array}$ & $\begin{array}{l}0 \\
0 \\
0 \\
0\end{array}$ & $\begin{array}{l}0 \\
0 \\
0 \\
0\end{array}$ & $\begin{array}{l}0 \\
0 \\
0 \\
0\end{array}$ & $\begin{array}{l}0 \\
0 \\
0 \\
0\end{array}$ & $\begin{array}{l}0 \\
0 \\
0 \\
0\end{array}$ & $\begin{array}{l}0 \\
0 \\
0 \\
0\end{array}$ & $\begin{array}{l}0 \\
0 \\
0 \\
0\end{array}$ & $\begin{array}{l}0 \\
0 \\
0 \\
0\end{array}$ & $\begin{array}{l}4.0 \\
4.2 \\
1.9 \\
1.7\end{array}$ & $\begin{array}{r}10.7 \\
11.3 \\
5.2 \\
4.4\end{array}$ & $\begin{array}{l}30.8 \\
32.5 \\
14.9 \\
12.7\end{array}$ \\
\hline$H P$ & & $\begin{array}{l}\text { crawl space } \\
\text { unconditioned } \\
\text { conditioned } \\
\text { slab }\end{array}$ & $\begin{array}{l}0 \\
0 \\
0 \\
0\end{array}$ & $\begin{array}{l}0 \\
0 \\
0 \\
0\end{array}$ & $\begin{array}{l}0 \\
0 \\
0 \\
0\end{array}$ & $\begin{array}{l}0 \\
0 \\
0 \\
0\end{array}$ & $\begin{array}{l}0 \\
0 \\
0 \\
0\end{array}$ & $\begin{array}{l}0 \\
0 \\
0 \\
0\end{array}$ & $\begin{array}{l}0 \\
0 \\
0 \\
0\end{array}$ & $\begin{array}{l}0 \\
0 \\
0 \\
0\end{array}$ & $\begin{array}{l}0 \\
0 \\
0 \\
0\end{array}$ & $\begin{array}{l}0 \\
0 \\
0 \\
0\end{array}$ & $\begin{array}{l}0 \\
0 \\
0 \\
0\end{array}$ & $\begin{array}{l}0 \\
0 \\
0 \\
0\end{array}$ & $\begin{array}{l}0 \\
0 \\
0 \\
0\end{array}$ & $\begin{array}{l}0 \\
0 \\
0 \\
0\end{array}$ & $\begin{array}{l}0 \\
0 \\
0 \\
0\end{array}$ & $\begin{array}{l}-2.4 \\
-4.8 \\
-4.6 \\
-4.8\end{array}$ & $\begin{array}{r}-6.3 \\
-12.8 \\
-12.3 \\
-12.8\end{array}$ & $\begin{array}{l}-18.1 \\
-36.9 \\
-35.4 \\
-36.9\end{array}$ \\
\hline GAS & $\begin{array}{l}\text { Multi- } \\
\text { Family }\end{array}$ & $\begin{array}{l}\text { crawl space } \\
\text { unconditianed } \\
\text { conditioned } \\
\text { s!ab }\end{array}$ & $\begin{array}{l}0 \\
0 \\
0 \\
0\end{array}$ & $\begin{array}{l}0 \\
0 \\
0 \\
0\end{array}$ & $\begin{array}{l}0 \\
0 \\
0 \\
0\end{array}$ & $\begin{array}{l}0 \\
0 \\
0 \\
0\end{array}$ & $\begin{array}{l}0 \\
0 \\
0 \\
0\end{array}$ & $\begin{array}{l}0 \\
0 \\
0 \\
0\end{array}$ & $\begin{array}{l}0 \\
0 \\
0 \\
0\end{array}$ & $\begin{array}{l}0 \\
0 \\
0 \\
0\end{array}$ & $\begin{array}{l}0 \\
0 \\
0 \\
0\end{array}$ & $\begin{array}{l}0 \\
0 \\
0 \\
0\end{array}$ & $\begin{array}{l}0 \\
0 \\
0 \\
0\end{array}$ & $\begin{array}{l}0 \\
0 \\
0 \\
0\end{array}$ & $\begin{array}{l}0 \\
0 \\
0 \\
0\end{array}$ & $\begin{array}{l}0 \\
0 \\
0 \\
0\end{array}$ & $\begin{array}{l}0 \\
0 \\
0 \\
0\end{array}$ & $\begin{array}{l}-0.2 \\
-2.0 \\
-1.8 \\
-2.0\end{array}$ & $\begin{array}{l}-0.5 \\
-5.2 \\
-4.9 \\
-5.2\end{array}$ & $\begin{array}{r}-1.4 \\
-15.1 \\
-14.2 \\
-15.1\end{array}$ \\
\hline ELECT. & & $\begin{array}{l}\text { crant space } \\
\text { unconditioned } \\
\text { conditioned } \\
\text { slab }\end{array}$ & $\begin{array}{l}0 \\
0 \\
0 \\
0\end{array}$ & $\begin{array}{l}0 \\
0 \\
0 \\
0\end{array}$ & $\begin{array}{l}0 \\
0 \\
0 \\
0\end{array}$ & $\begin{array}{l}0 \\
0 \\
0 \\
0\end{array}$ & $\begin{array}{l}0 \\
0 \\
0 \\
0\end{array}$ & $\begin{array}{l}0 \\
0 \\
0 \\
0\end{array}$ & $\begin{array}{l}0 \\
0 \\
0 \\
0\end{array}$ & $\begin{array}{l}0 \\
0 \\
0 \\
0\end{array}$ & $\begin{array}{l}0 \\
0 \\
0 \\
0\end{array}$ & $\begin{array}{l}0 \\
0 \\
0 \\
0\end{array}$ & $\begin{array}{l}0 \\
0 \\
0 \\
0\end{array}$ & $\begin{array}{l}0 \\
0 \\
0 \\
0\end{array}$ & $\begin{array}{l}0 \\
0 \\
0 \\
0\end{array}$ & $\begin{array}{l}0 \\
0 \\
0 \\
0\end{array}$ & $\begin{array}{l}0 \\
0 \\
0 \\
0\end{array}$ & $\begin{array}{l}4.0 \\
1.6 \\
0.2 \\
0.0\end{array}$ & $\begin{array}{r}10.7 \\
4.2 \\
0.6 \\
0.0\end{array}$ & $\begin{array}{r}30.8 \\
12.0 \\
1.8 \\
0.0\end{array}$ \\
\hline HP & & $\begin{array}{l}\text { crawl space } \\
\text { unconditioned } \\
\text { conditioned } \\
\text { slab }\end{array}$ & $\begin{array}{l}0 \\
0 \\
0 \\
0\end{array}$ & $\begin{array}{l}0 \\
0 \\
0 \\
0\end{array}$ & $\begin{array}{l}0 \\
0 \\
0 \\
0\end{array}$ & $\begin{array}{l}0 \\
0 \\
0 \\
0\end{array}$ & $\begin{array}{l}0 \\
0 \\
0 \\
0\end{array}$ & $\begin{array}{l}0 \\
0 \\
0 \\
0\end{array}$ & $\begin{array}{l}0 \\
0 \\
0 \\
0\end{array}$ & $\begin{array}{l}0 \\
0 \\
0 \\
0\end{array}$ & $\begin{array}{l}0 \\
0 \\
0 \\
0\end{array}$ & $\begin{array}{l}0 \\
0 \\
0 \\
0\end{array}$ & $\begin{array}{l}0 \\
0 \\
0 \\
0\end{array}$ & $\begin{array}{l}0 \\
0 \\
0 \\
0\end{array}$ & $\begin{array}{l}0 \\
0 \\
0 \\
0\end{array}$ & $\begin{array}{l}0 \\
0 \\
0 \\
0\end{array}$ & $\begin{array}{l}0 \\
0 \\
0 \\
0\end{array}$ & $\begin{array}{l}6.3 \\
4.8 \\
4.9 \\
4.8\end{array}$ & $\begin{array}{l}16.9 \\
12.7 \\
13.0 \\
12.7\end{array}$ & $\begin{array}{l}48.5 \\
36.5 \\
37.4 \\
36.5\end{array}$ \\
\hline GAS & $\begin{array}{l}\text { Manu- } \\
\text { factured }\end{array}$ & crawl space & 0 & 0 & 0 & 0 & 0 & 0 & 0 & 0 & 0 & 0 & 0 & 0 & 0 & 0 & 0 & -0.8 & -2.3 & -6.5 \\
\hline PROPANE & Home & crawl space & 0 & 0 & 0 & 0 & 0 & 0 & 0 & 0 & 0 & 0 & 0 & 0 & 0 & 0 & 0 & 5.4 & 14.5 & 41.7 \\
\hline ELECT. & & crakl space & 0 & 0 & 0 & 0 & 0 & 0 & 0 & 0 & 0 & 0 & 0 & 0 & 0 & 0 & 0 & 8.3 & 22.1 & 63.7 \\
\hline
\end{tabular}


TABLE 3.3h Summary of Incremental Changes in Pollutant Levels from the Base Code to the Proposed Voluntary Standard for Providence

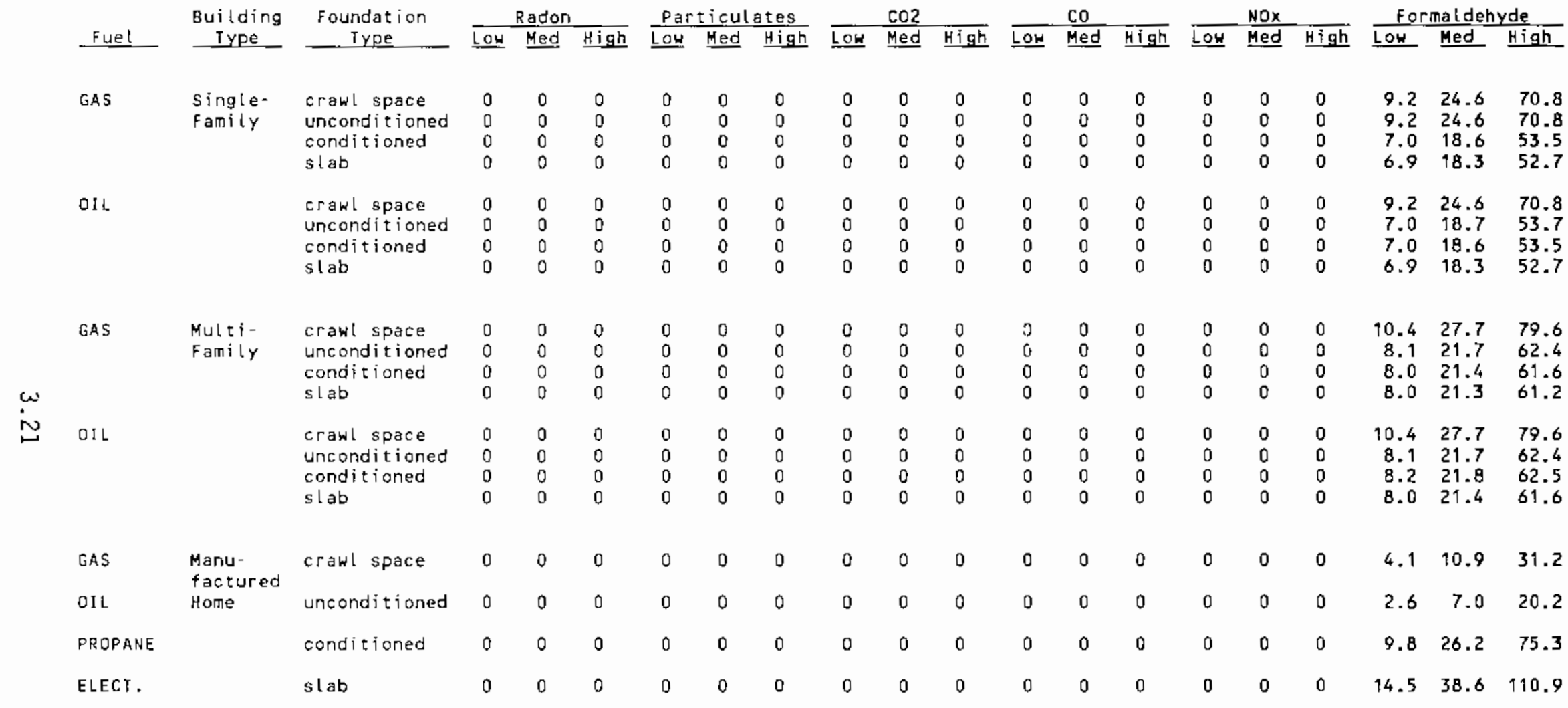


TABLE 3.3i Summary of Incremental Changes in PolTutant Levels from the Base Code to the Proposed Voluntary Standard for Seattle

\begin{tabular}{|c|c|c|c|c|c|c|c|c|c|c|c|c|c|c|c|c|c|c|c|c|}
\hline \multirow[b]{2}{*}{ Fuel. } & \multirow{2}{*}{$\begin{array}{l}\text { Building } \\
\text { Type. }\end{array}$} & \multirow{2}{*}{$\begin{array}{c}\text { Foundation } \\
\text { Type }\end{array}$} & \multicolumn{3}{|c|}{ Radon } & \multicolumn{3}{|c|}{ Particulates } & \multicolumn{3}{|c|}{$\mathrm{CO} 2$} & \multicolumn{3}{|c|}{ co } & \multicolumn{3}{|c|}{ NOX } & \multicolumn{3}{|c|}{ Formal dehyde } \\
\hline & & & LOH & Med & High & Low & Med & High & $\underline{\underline{L}}$ & Med & $\underline{\mathrm{High}}$ & Low & Med & High & LOW & Med & $\underline{\mathrm{High}}$ & LOH & Hed & $\mathrm{High}$ \\
\hline GAS & $\begin{array}{l}\text { Single- } \\
\text { family }\end{array}$ & $\begin{array}{l}\text { crawl space } \\
\text { unconditioned } \\
\text { conditioned } \\
\text { slab }\end{array}$ & $\begin{array}{l}0 \\
0 \\
0 \\
0\end{array}$ & $\begin{array}{l}0 \\
0 \\
0 \\
0\end{array}$ & $\begin{array}{l}0 \\
0 \\
0 \\
0\end{array}$ & $\begin{array}{l}0 \\
0 \\
0 \\
0\end{array}$ & $\begin{array}{l}0 \\
0 \\
0 \\
0\end{array}$ & $\begin{array}{l}0 \\
0 \\
0 \\
0\end{array}$ & $\begin{array}{l}0 \\
0 \\
0 \\
0\end{array}$ & $\begin{array}{l}0 \\
0 \\
0 \\
0\end{array}$ & $\begin{array}{l}0 \\
0 \\
0 \\
0\end{array}$ & $\begin{array}{l}0 \\
0 \\
0 \\
0\end{array}$ & $\begin{array}{l}0 \\
0 \\
0 \\
0\end{array}$ & $\begin{array}{l}0 \\
0 \\
0 \\
0\end{array}$ & $\begin{array}{l}0 \\
0 \\
0 \\
0\end{array}$ & $\begin{array}{l}0 \\
0 \\
0 \\
0\end{array}$ & $\begin{array}{l}0 \\
0 \\
0 \\
0\end{array}$ & $\begin{array}{l}6.2 \\
4.8 \\
4.6 \\
4.8\end{array}$ & $\begin{array}{l}16.4 \\
12.8 \\
12.3 \\
12.8\end{array}$ & $\begin{array}{l}47.2 \\
36.9 \\
35.4 \\
36.9\end{array}$ \\
\hline ELECT. & & $\begin{array}{l}\text { crawl space } \\
\text { unconditioned } \\
\text { condit ioned } \\
\text { slab }\end{array}$ & $\begin{array}{l}0 \\
0 \\
0 \\
0\end{array}$ & $\begin{array}{l}0 \\
0 \\
0 \\
0\end{array}$ & $\begin{array}{l}0 \\
0 \\
0 \\
0\end{array}$ & $\begin{array}{l}0 \\
0 \\
0 \\
0\end{array}$ & $\begin{array}{l}0 \\
0 \\
0 \\
0\end{array}$ & $\begin{array}{l}0 \\
0 \\
0 \\
0\end{array}$ & $\begin{array}{l}0 \\
0 \\
0 \\
0\end{array}$ & $\begin{array}{l}0 \\
0 \\
0 \\
0\end{array}$ & $\begin{array}{l}0 \\
0 \\
0 \\
0\end{array}$ & $\begin{array}{l}0 \\
0 \\
0 \\
0\end{array}$ & $\begin{array}{l}0 \\
0 \\
0 \\
0\end{array}$ & $\begin{array}{l}0 \\
0 \\
0 \\
0\end{array}$ & $\begin{array}{l}0 \\
0 \\
0 \\
0\end{array}$ & $\begin{array}{l}0 \\
0 \\
0 \\
0\end{array}$ & $\begin{array}{l}0 \\
0 \\
0 \\
0\end{array}$ & $\begin{array}{l}-0.2 \\
-0.2 \\
-1.4 \\
-1.5\end{array}$ & $\begin{array}{l}-0.6 \\
-0.6 \\
-3.7 \\
-3.9\end{array}$ & $\begin{array}{r}-1.7 \\
-1.7 \\
-10.5 \\
-11.2\end{array}$ \\
\hline HP & & $\begin{array}{l}\text { crawl space } \\
\text { unconditioned } \\
\text { conditioned } \\
\text { slab }\end{array}$ & $\begin{array}{l}0 \\
0 \\
0 \\
0\end{array}$ & $\begin{array}{l}0 \\
0 \\
0 \\
0\end{array}$ & $\begin{array}{l}0 \\
0 \\
0 \\
0\end{array}$ & $\begin{array}{l}0 \\
0 \\
0 \\
0\end{array}$ & $\begin{array}{l}0 \\
0 \\
0 \\
0\end{array}$ & $\begin{array}{l}0 \\
0 \\
0 \\
0\end{array}$ & $\begin{array}{l}0 \\
0 \\
0 \\
0\end{array}$ & $\begin{array}{l}0 \\
0 \\
0 \\
0\end{array}$ & $\begin{array}{l}0 \\
0 \\
0 \\
0\end{array}$ & $\begin{array}{l}0 \\
0 \\
0 \\
0\end{array}$ & $\begin{array}{l}0 \\
0 \\
0 \\
0\end{array}$ & $\begin{array}{l}0 \\
0 \\
0 \\
0\end{array}$ & $\begin{array}{l}0 \\
0 \\
0 \\
0\end{array}$ & $\begin{array}{l}0 \\
0 \\
0 \\
0\end{array}$ & $\begin{array}{l}0 \\
0 \\
0 \\
0\end{array}$ & $\begin{array}{l}5.2 \\
2.7 \\
3.7 \\
3.9\end{array}$ & $\begin{array}{r}13.8 \\
7.3 \\
9.8 \\
10.3\end{array}$ & $\begin{array}{l}39.8 \\
21.0 \\
28.1 \\
29.5\end{array}$ \\
\hline $\begin{array}{l}\omega \\
N \\
N\end{array}$ & $\begin{array}{l}\text { Multi- } \\
\text { Family }\end{array}$ & $\begin{array}{l}\text { crawl space } \\
\text { unconditioned } \\
\text { conditioned } \\
\text { slab }\end{array}$ & $\begin{array}{l}0 \\
0 \\
0 \\
0\end{array}$ & $\begin{array}{l}0 \\
0 \\
0 \\
0\end{array}$ & $\begin{array}{l}0 \\
0 \\
0 \\
0\end{array}$ & $\begin{array}{l}0 \\
0 \\
0 \\
0\end{array}$ & $\begin{array}{l}0 \\
0 \\
0 \\
0\end{array}$ & $\begin{array}{l}0 \\
0 \\
0 \\
0\end{array}$ & $\begin{array}{l}0 \\
0 \\
0 \\
0\end{array}$ & $\begin{array}{l}0 \\
0 \\
0 \\
0\end{array}$ & $\begin{array}{l}0 \\
0 \\
0 \\
0\end{array}$ & $\begin{array}{l}0 \\
0 \\
0 \\
0\end{array}$ & $\begin{array}{l}0 \\
0 \\
0 \\
0\end{array}$ & $\begin{array}{l}0 \\
0 \\
0 \\
0\end{array}$ & $\begin{array}{l}0 \\
0 \\
0 \\
0\end{array}$ & $\begin{array}{l}0 \\
0 \\
0 \\
0\end{array}$ & $\begin{array}{l}0 \\
0 \\
0 \\
0\end{array}$ & $\begin{array}{l}-0.2 \\
-2.7 \\
-1.6 \\
-1.6\end{array}$ & $\begin{array}{l}-0.6 \\
-7.1 \\
-4.2 \\
-4.2\end{array}$ & $\begin{array}{r}-1.7 \\
-20.5 \\
-12.0 \\
-12.0\end{array}$ \\
\hline ELECT. & & $\begin{array}{l}\text { cras! space } \\
\text { unconditioned } \\
\text { condit ioned } \\
\text { slab }\end{array}$ & $\begin{array}{l}0 \\
0 \\
0 \\
0\end{array}$ & $\begin{array}{l}0 \\
0 \\
0 \\
0\end{array}$ & $\begin{array}{l}0 \\
0 \\
0 \\
0\end{array}$ & $\begin{array}{l}0 \\
0 \\
0 \\
0\end{array}$ & $\begin{array}{l}0 \\
0 \\
0 \\
0\end{array}$ & $\begin{array}{l}0 \\
0 \\
0 \\
0\end{array}$ & $\begin{array}{l}0 \\
0 \\
0 \\
0\end{array}$ & $\begin{array}{l}0 \\
0 \\
0 \\
0\end{array}$ & $\begin{array}{l}0 \\
0 \\
0 \\
0\end{array}$ & $\begin{array}{l}0 \\
0 \\
0 \\
0\end{array}$ & $\begin{array}{l}0 \\
0 \\
0 \\
0\end{array}$ & $\begin{array}{l}0 \\
0 \\
0 \\
0\end{array}$ & $\begin{array}{l}0 \\
0 \\
0 \\
0\end{array}$ & $\begin{array}{l}0 \\
0 \\
0 \\
0\end{array}$ & $\begin{array}{l}0 \\
0 \\
0 \\
0\end{array}$ & $\begin{array}{l}-0.2 \\
-0.2 \\
-1.4 \\
-1.5\end{array}$ & $\begin{array}{l}-0.6 \\
-0.6 \\
-3.9 \\
-4.0\end{array}$ & $\begin{aligned} & -1.7 \\
- & -1.7 \\
- & 11.1 \\
- & 11.5\end{aligned}$ \\
\hline HP & & $\begin{array}{l}\text { crawl space } \\
\text { unconditioned } \\
\text { conditioned } \\
\text { slab }\end{array}$ & $\begin{array}{l}0 \\
0 \\
0 \\
0\end{array}$ & $\begin{array}{l}0 \\
0 \\
0 \\
0\end{array}$ & $\begin{array}{l}0 \\
0 \\
0 \\
0\end{array}$ & $\begin{array}{l}0 \\
0 \\
0 \\
0\end{array}$ & $\begin{array}{l}0 \\
0 \\
0 \\
0\end{array}$ & $\begin{array}{l}0 \\
0 \\
0 \\
0\end{array}$ & $\begin{array}{l}0 \\
0 \\
0 \\
0\end{array}$ & $\begin{array}{l}0 \\
0 \\
0 \\
0\end{array}$ & $\begin{array}{l}0 \\
0 \\
0 \\
0\end{array}$ & $\begin{array}{l}0 \\
0 \\
0 \\
0\end{array}$ & $\begin{array}{l}0 \\
0 \\
0 \\
0\end{array}$ & $\begin{array}{l}0 \\
0 \\
0 \\
0\end{array}$ & $\begin{array}{l}0 \\
0 \\
0 \\
0\end{array}$ & $\begin{array}{l}0 \\
0 \\
0 \\
0\end{array}$ & $\begin{array}{l}0 \\
0 \\
0 \\
0\end{array}$ & $\begin{array}{l}-2.7 \\
-2.7 \\
-1.6 \\
-1.6\end{array}$ & $\begin{array}{l}-7.1 \\
-7.1 \\
-4.2 \\
-4.2\end{array}$ & $\begin{array}{l}-20.5 \\
-20.5 \\
-12.0 \\
-12.0\end{array}$ \\
\hline GAS & $\begin{array}{l}\text { Manu- } \\
\text { factured }\end{array}$ & crawl space & 0 & 0 & 0 & 0 & 0 & 0 & 0 & 0 & 0 & 0 & 0 & 0 & 0 & 0 & 0 & 1.1 & 3.0 & 8.6 \\
\hline PROPANE & Home & crawl space & 0 & 0 & 0 & 0 & 0 & 0 & 0 & 0 & 0 & 0 & 0 & 0 & 0 & 0 & 0 & 2.6 & 6.8 & 19.6 \\
\hline ELECT. & & crawl space & 0 & 0 & 0 & 0 & 0 & 0 & 0 & 0 & 0 & 0 & 0 & 0 & 0 & 0 & 0 & 8.3 & 22.1 & 63.7 \\
\hline
\end{tabular}


TABLE 3.3.j Summary of Incremental Changes in Pollutant Levels from the Base code to the Proposed Voluntary Standard for Tampa

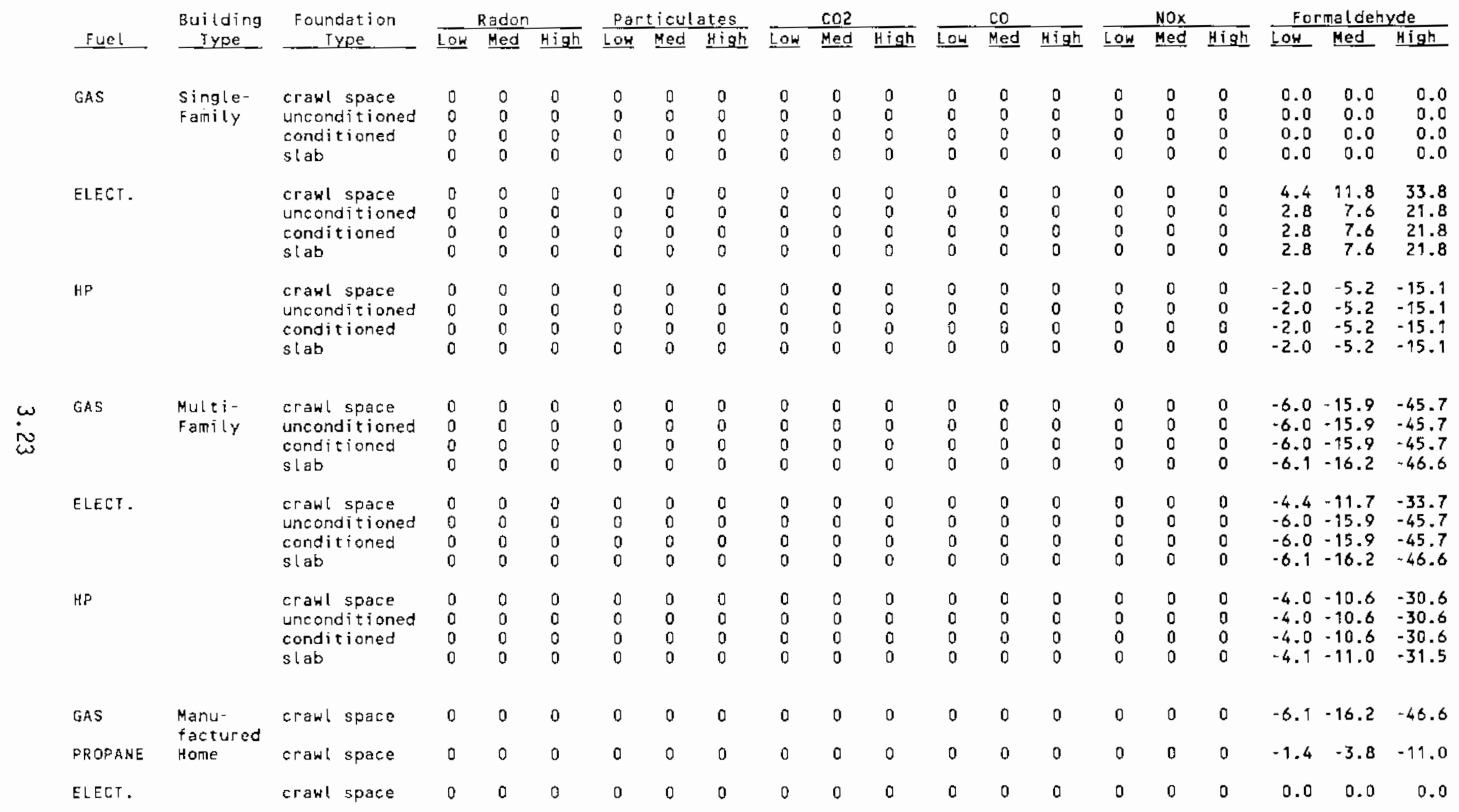


assumed to smoke 31 cigarettes a day (NRC 1981a). However, not all of an occupant's smoking is done within the residential unit. Assuming one smoker in the residence sroking $80 \%$ of his/her nonsleeping time, then an average of 25 cigarettes would be smoked in the residence per day. If two smokers occupy the residence, it is assumed that the second srioker occupies the resident $40 \%$ of his/her nonsleeping time and averages 12 cigarettes per day srioked within the residentiai unit.

Heaith Impacts. Carbon monoxide is many times more efficient at binding with hemoglobin than oxygen (Meyer 1983). Thus, low concentrations of co in indoor air can result in substantial carboxyhemoglobin (COHb) concentrations in the blood (see Appendix D). Available information on health risks suggests that persons with angina, peripheral vascular disease, and other types of cardiovascular disease are at the greatest risk from low-levels of CO (Anderson et a1. 1973). Current studies do not show significant health risks if co concentrations are below $10 \mathrm{ng} / \mathrm{m}$ as an 8-h average (see Appendix D for details).

Expected Impact of the Proposed Voluntary Standard. Tabies 3.3a through $3.3 \mathrm{j}$ show the incremental change in computed indoor concentrations of co for the baseline and for the proposed standard. For all house types and locations, there was no change in indoor levels of $\mathrm{CO}$ as a result of the proposed voluntary standard when $\mathrm{ACH}$ is assumed to be unchanged.

Findings. The proposed voluntary standard will not have an effect on indoor concentrations of $\mathrm{CO}$.

\section{Carbon Dioxide}

Human breathing is a significant source of carbon dioxide $\left(\mathrm{CO}_{2}\right)$. Norme. 1 respiration produces $8.9 \mathrm{mg} / \mathrm{second}$ of $\mathrm{C}_{2}$ per person. Other sources include! cigarette smoking (80 $\mathrm{mg}$ of $\mathrm{CO}_{2}$ per cigarette), gas stoves $(483,000$ to $550,000 \mathrm{mg} /$ burner-h), and gas ovens $(383,000$ to $400,000 \mathrm{mg} /$ burner-h).

Health Impacts. Excessive carbon dioxide triggers increased breathing to maintain the proper exchange of oxygen and $\mathrm{CO}_{2}$. If inhaled air aiready contains high levels of $\mathrm{CO}_{2}$, then the breathing rate has to be increased to purge $\mathrm{CO}_{2}$ at the rate it is produced (Meyer 1983). The 0ccupational Safety and Health Administration (OSHA) has a $\mathrm{CO}_{2}$ standard for the workplace of 
$9,000 \mathrm{mg} / \mathrm{m}^{3}$. ASHRAE has a recommended guideline for the nonworkplace of $4,500 \mathrm{mg} / \mathrm{m}^{3}$ continuous (24-h per day) exposure [Bonneville Power Administration (BPA) 1984]. Japan is the only country to have established an indoor standard for $\mathrm{CO}_{2}$ applicable to residences. The Japanese standard is $1,800 \mathrm{mg} / \mathrm{m}^{3}$ for continuous exposure (WaIsh 1984).

Expected Impact of the Proposed Voluntary Standard. Table 3.3a through $3.3 \mathrm{j}$ show the incremental change in computed concentrations of $\mathrm{CO}_{2}$ for the baseline and proposed standard units. Indoor concentrations of $\mathrm{CO}_{2}$ renained unchanged as a result of the proposed voluntary standard when ACH was held constant.

Findings. The proposed voluntary standard will have no affect on indoor concentrations of $\mathrm{CO}_{2}$.

\section{Nitrogen Dioxide}

The sources of nitrogen dioxide $\left(\mathrm{NO}_{2}\right)$ addressed in this assessment are gas stoves and ovens and cigarette smoking. Cole et al. (1983) reports that gas range-top burners release $\mathrm{NO}_{2}$ at a rate of 70 to $120 \mathrm{mg} /$ burner-h of operation. Gas ovens release rates between 80 and $130 \mathrm{mig} / 0$ en-h of operation have been noted by Giman et a1. (1981). A NO 2 source term for tobacco smoking has a1so been measured and averages $0.065 \mathrm{mg} / \mathrm{cigarette}$ (NRC 1981a).

Health Impacts. The most sensitive populations to low levels of $\mathrm{NO}_{2}$ are children and persons with asthma, chronic bronchitis, and emphysena (see Appendix D). Other persons who have hay fever or liver or hormonal disorders may also be affected at low levels of $\mathrm{NO}_{2}$. As noted in Appendix D, trying to separate health effects caused by $\mathrm{NO}_{2}$ from health effects caused by other pollutants is very difficult because community epideniology studies do not provide clear evidence of the effects of low levels of $\mathrm{NO}_{2}$. However, the studies also do not disprove that there is an association between low levels of $\mathrm{NO}_{2}$ and health risk. Thus, based principally on controlled human exposure studies, the EPA (1982) currently considers that $\mathrm{NO}_{2}$ concentration levels below $90 \mu \mathrm{g} / \mathrm{m}^{3}$ on an annual average can provide adequate protection against harmful health effects from low levels of $\mathrm{NO}_{2}$ (see Appendix D). 
Expected Impact of the Proposed Voluntary Standard. Tables 3.3a through $3.3 \mathrm{j}$ show the incremental change in computed concentration of $\mathrm{NO}_{2}$ based on release of $\mathrm{NO}_{2}$ from gas cooking appliances and smioking. No changes in $\mathrm{NO}_{2}$ concentrations will occur as a result of the proposed voluntary standard if $A C H$ is not modified.

Findings. Release of $\mathrm{NO}_{2}$ from cooking appliances and tobacco smoking is small. The computed concentrations for $\mathrm{NO}_{2}$ for the proposed standard are unchanged from those computed for the baseline residences. Thus, the proposed voluntary standard would have no effect on annual $\mathrm{NO}_{2}$ levels in residentia? structures.

Radon

The greatest single source of radon is soil. Source terms fron the soil range from 0.1 to 1 pico curies per square meter of soil per second $\left(\mathrm{pci} / \mathrm{m}^{2}\right.$. $\mathrm{sec}$ ) in the low-radon release areas to 1 to $10 \mathrm{pci} / \mathrm{m}^{2}-\mathrm{sec}$ in high-radon release localities. Radon is also released from the aggregate contained in concrete. Release rates range froln 0.02 to $0.06 \mathrm{pCi} / \mathrm{r}^{2}-\mathrm{sec}$ for each side of a 0.2 -meterthick wall. A concrete slab on soil will enanate radon both from the concrete aggregate and from the diffusion of the radon from the soil through the pores, cracks, and holes in the concrete. An intact concrete slab without cracks or leaks through pipes will reduce flux fron soil beneath it by a factor of about 10 (Bruno 1981); a vented crawl space can further reduce flux. The magnitude: of the source tern depends on whether the slab is on soil in a high-radon or a low-radon release area. Unfortunately, there is no complete map of where hiughradon release areas are located. Attempts to correlate geological surface features with radon release rates have had mixed results.

Brick (adobe and red) building material is also a source of gaseous radon. Another major source of indoor radon is water from underground supplies. Radon emission rates from water were selected to cover the expected range to be found in community water systems.

The greatest variability in radon source terms is associated with geological features (water supply and substrate); considerabiy less variability occurs in the building materials (Sachs, Hernandez and Ping 1982; Abu-Jarad and 
Fremlin 1982). Ambient outdoor radon concentrations show considerable variation due to soil and weather factors. A background atmospheric value of 0.25 pico curies per liter $(p \mathrm{C} i / \ell)$ is typical.

Health Impacts. Radon gas and its decay products are present everywhere in concentrations that vary with location, the time of day, and weather conditions. Decay products in the air we breathe can become deposited and retained in the lungs, sometimes contributing to lung cancer. Studies (e.g., Evans 1967, Jorgensen 1973 and Archer 1978) show that uranium miners, who are subjected to elevated levels of radon and radon daughters, have higher rates of lung cancer than the general population.

Because the effects of radon exposure seem to be cumulative, contributions to individual exposures from all sources (e.g., residences, commercial buildings, and outdoor air) nust be considered. The severity of an individual's reaction to radon gas exposure will depend on many factors, such as the length of the exposure and the concentration levels. The research data developed from radon daughter epidemiology studies suggest that an absolute threshold exposure for lung cancer induction has not been identified. Thus, for very low levels of exposure, such as those typically associated with indoor air, researchers have not fully agreed on the impact of radiation on human health. More detailed information on radon and its health effects is presented in Appendix D.

Expected Impact of the Proposed Voluntary Standard. Incremental changes in radon concentrations were computed for each of the residences and are presented in Tables $3.3 \mathrm{a}$ through $3.3 \mathrm{j}$. The low, mediun, and high values are derived from the source-term assumptions discussed above. The design changes related to the proposed voluntary standard do not affect indoor radon concentrations.

Findings. The proposed voluntary standard will not affect indoor radon concentrations.

It is not the intent of this radon evaluation to dismiss the potential hazard of the presence of radon in the indoor environment. However, comparison between the baseline residence constructed according to current practices and 
the same residence constructed according to the proposed standard using the normal infiltration rate clearly indicates that no change would occur as a result of the proposed standard as long as infiltration rates are not modified. Thus, no change in health risk from indoor radon concentrations would occur. Note that radon release from soil, water, and building materials varias greatly from site to site and should remain a major health concern until test; determine that radon is not present at elevated levels on a given site in a specific building. (Radon concentrations can vary considerably from building to building at the same location.)

\section{Formaldehyde}

Formaldehyde is a substance used in the manufacture of many building materials. Insulation, particle board, plywood, wall board, and similar construction materials are all major indoor sources of gaseous formaldehyde. Formaldehyde can also be emitted during combustion processes. Typical eniss on rates for gas cooking appliances range from $15 \mathrm{mg} /$ burner-h for range-top burners to $25 \mathrm{mg} / 0$ ven-h for ovens. Formaldehyde is also a component of sidestream cigarette smoke (i.e., snoke released from the burning tip of a cigarette). Typically, about $1 \mathrm{mg}$ of formaldehyde is released for each cigaretta smoked (NRC 1981a).

Release rates for formaldehyde vary because many factors are involved. Andersen (1979) found that indoor formaldehyde concentrations in Danish homes are a function of air temperature, humidity, air change rate, ratio of particle board surface area to roon volume, and surface coating and type of particle board used. Age has also been identified as a factor in formaldehyde release; about half of the formaldehyde in particle board, for instance, is released over a period of 58 months (NRC 1981b). Ventilation rates, humidity, and the amount of resinous naterial in a residence seem to be the most important fai:tors that contribute to airborne formaldehyde accuriulation. Standards have been established by HUD for manufactured homes limiting permissible anounts of formaldehyde emissions from the plywood and particle board used in these homes. These restrictions are designed to limit indoor formaldehyde concentrations to 0.4 ppr. 
Health Inpacts. In low concentrations, formaldehyde irritates the eyes and mucous membranes of the nose and throat (NRC 1981b). The severity of the symptoms increases with concentration. Some human beings are much more sensitive to formaldehyde than others. For example, formaldehyde odor is most commonly detected at $1,200 \mu \mathrm{g} / \mathrm{m}^{3}$, but some individuals can detect formaldehyde odor at concentrations of 60 to $70 \mu \mathrm{g} / \mathrm{m}^{3}$. Eye irritation has been reported at formaldehyde concentrations as $10 \mathrm{w}$ as $10 \mu \mathrm{g} / \mathrm{m}^{3}$ (see Appendix D for more details).

The Consumer Product Safety Commission (CPSC) has received numerous complaints about formaldehyde concentrations in residential buildings. The CPSC reports that residential concentrations of 10 to $120 \mu \mathrm{g} / \mathrm{m}^{3}$ have been identified as causing nausea; eye, nose, and throat irritations; headache; vomiting; and stomach cramps (Greisemer et al. 1980). Research information compiled by Gupta, U1samer and Preuss (1982) verifies that the human threshold for shortterm exposure to low concentrations of formaldehyde varies widely.

The National Acaderiy of Science (NAS) concluded that there is no population threshold for the irritant effects of formaldehyde (NAS 1980). Persons sensitized to formaldehyde and persons with hyperactive airways may respond severely to formaldehyde (NAS 1981). The Academy has estimated that $10 \%$ to $12 \%$ of the U.S. population may have hyperactive airways, which may make them more susceptible to the irritant effects of formaldehyde (NAS 1981b).

Expected Impact of the Proposed Voluntary Standard. The incremental change in computed indoor concentrations of formaldehyde from levels of insulation specified by the proposed standard are shown in Tables 3.3a through $3.3 j$. The emission rates displayed are those for new insulation. Formaldehyde emission rates and resulting concentrations would drop as the material ages. With no alteration in $\mathrm{ACH}$ between base codes and the proposed voluntary standard, the changes in formaldehyde concentrations are proportional to the increases (or decreases) in the total mass of insulation in the building that would be required to meet the proposed standard.

Findings. Formaldehyde concentrations are expected to increase slightly in some building types in some locations (e.g., single family residences in Atlanta). Although the increases are smalt (generally less than $30 \mathrm{mg} / \mathrm{cubic}$ 
meter for the typical emission rates), the change could have a negative impact, on extremely sensitive individuals with a very low tolerance for airborne formaldehyde.

\section{Chemical Compounds}

Measurement studies have shown that a wide variety of chemical contaminants, many of which are organic compounds, are present in residential indoor air. Over 300 chemical compounds have been positively identified in residential air. Several studies have addressed the difficult problem of quantifyinj the exact concentrations present in indoor air. This assessment has focused in those compounds that have indoor air concentrations greater than outdoor levels. Chemical compounds identified in five studies of residential air are presented in Appendix $C$. One study indicated that chemical compounds found in indoor residential air generally occur in low concentrations relative to industrial hygiene exposure levels, aithough as mentioned above, they occur in higl concentrations relative to outdoor concentrations (Hiksch, Hollowell and Schmidt 1982).

The presence of chemical compounds in residential air results from one or more of the following sources.

- infiltration of outdoor chemicals

- episodic events (í.e., cooking or cleaning)

- natural consequences of indoor living (respiration and perspiration)

- outgassing from household appliances and building materials.

Each of these sources is discussed in Appendix $C$.

Health Impacts. The chemical compounds found in indoor residential air are treated in this document as one complex class of indoor pollutants emanating from many sources. Moreover, because of the large number of chemical compounds potentially present in residential buildings, comprehensive discussion of each compound is impractical. The health effects of chemical pollutants are relatively uncertain. Molhave (1982) sumarizes the number of expected carcinogens, airway jrritants, and odorous organic compounds that he was able to detect from 42 commonly used building materials in chamber emission 
studies. A total of 52 different compounds were identified: $25 \%$ were suspected carcinogens, $82 \%$ were known or suspected airway irritants, and $30 \%$ were odorous compounds (see Appendix C).

Expected Impact of the Proposed Voluntary Standard. Design of residential buildings to meet the proposed voluntary standard should not influence two important sources of chemical pollutants in indoor air: occupant-stimulated episodal events (such as cooking, cleaning etc.), and natural consequences of indoor living (respiration, perspiration). These sources are influenced more by the number of occupants and their living habits than by the air exchange rate. If residents follow the directions on consumer products and provide adequate ventilation while they are using the products indoors, the pollutant concentration levels should be low.

Building materials are thought to be another major source of chemical pollutants (Molhave 1982). Residences designed to meet baseline conditions and residences designed to meet the proposed voluntary standard use the same inventory of building materials, except for the amount of insulation materials. Table 3.4 shows expected chemica? rates from new building insulation materials. Where the proposed standard allows for reduced insulation, emissions of formaldehyde from fiberglass would be reduced. Where insulation materials such as polystyrene are used, organic enission sources would increase. Strategies that can mitigate the level of chemical compounds emanating from building materials include "drying out" the building for a specific period of time to reduce emission levels before occupancy and selecting less emissive or harmful materials.

Findings. A large number of chenical pollutants have been identified in indoor residential air. llany of these chemical compounds are either odorous, irritants, or suspected carcinogens. Although many of the chemical compounds found in indoor air come from building materiais (emanation rates for which decline with age), many others are related to occupants and their activities. Fron the infornation used in this study, it is evident that chemical compounds can pose health risks to residential occupants in either short-term episodal or long-term acute concentrations. As with other indoor air pollutants discussed above, the sensitivities of individuals to these indoor chemical pollutants 
TABLE 3.4. Organic Emissions from New Building Insulation llaterials

\begin{tabular}{|c|c|c|c|}
\hline Material & Description & $\begin{array}{l}\text { Organic }(a) \\
\text { Emissjon } \\
\left(\mathrm{mg} / \mathrm{m}^{2}-\mathrm{hr}\right)\end{array}$ & $\begin{array}{c}\text { Formaldehyde }(b) \\
\text { Emission } \\
\left(\mathrm{mg} / \mathrm{m}^{2}-\mathrm{hr}\right)\end{array}$ \\
\hline Fiberglass & Fiberboard, $0.5 "$ & 0.017 & $N M(c)$ \\
\hline Fiberglass & Batt, $3.0^{\prime \prime}$ & NH1 & 0.02 to 0.17 \\
\hline Mineral Wool & Insulation Batt & 0.012 & $N M$ \\
\hline Organic & Woodfiber Board & 0.120 & $\mathrm{~N}: 1$ \\
\hline Foant & Polystyrene & 1.4 & N'1 \\
\hline Foafin & Polyurethane & 0.12 & $\mathrm{NH}$ \\
\hline $\begin{array}{l}\text { (a) Taken from } \\
\text { (b) Comparable } \\
\text { emission ra } \\
\text { (c) NH = not me }\end{array}$ & $\begin{array}{l}\text { Holhave (1982). } \\
\text { form of emission } \\
\text { te given by Gupt } \\
\text { asured. }\end{array}$ & $\begin{array}{l}\text { fed from } \\
\text { amer and }\end{array}$ & $\begin{array}{l}02.3 \mu \mathrm{g} / \mathrm{g}-\mathrm{day} \\
(1982)^{\circ}\end{array}$ \\
\hline
\end{tabular}

will vary widely. The proposed voluntary standard is not, however, expected to measurably increase or decrease health risks due to chemical pollutants in residential indoor air.

\section{Microorganisms}

Microorganisms are indoor air pollutants with potential health risks uncler selected conditions. Thus, airborne nicroorganisms are recognized as factors; to be considered in indoor environments. A broad array of algae, bacteria, fungi, protozoa, mites, and viruses are present. They are capable of provok"ng toxicity, infection, and allergenic responses. Some level of microorganisns on the human body and in the indoor environment is normal. Human response to microorganisms depends on the ability of the microorganism to produce diseas 3 and on the "immunity" of the individual, which can vary from person to person. Thus, the aliergenic response, toxic reaction, infection, and dermal or mucous nembrane irritations from exposure to microorganisms depend on the type of microorganism, its concentration, and the susceptibility of the cxposed individual. 
Most severe pollution problems from indoor microorganisms result from growth of the organism on sorie water reservoir or moist surface within the residence. Thus, any area where flooding has occurred or where noisture condenses may host a colony of microorganisms. When the host site is attached or adjacent to a residential central air-handling systern, the microorganisms have a potential path for distribution beyond their immediate growth area. Because outdoor air flows into a residence through the building's envelope (ceiling, floor, and exterior walls), microorganisms around the foundation of a residence and in the intrawall space can also be sources of indoor pollution.

There are many sources of moisture in residential structures. These include respiration and perspiration from humans and pets; occupant activities including laundry (washing and mechanical drying), cooking, cleaning, showering, bathing, indoor hot tubs and saunas; water vapor transported into the home in moisture-laden air from the outside air and diffusing from the soit through cracks in the flooring and foundation; use of humidifiers; plants; construction materials; and use of unvented gas appliances.

A typical family of 4 will generate from 13-44 ib (6-20 liters) per day of moisture indoors depending upon its activity levels and ventilation (air exchange rate) of the residence (KaduTski 1988; National Research Council of Canada 1984). The ultimate indoor humidity (moisture) level of a residence is a function of the number of sources of moisture and their source strength, the rate of fresh air ventilation of the home, and the ventilation effectiveness.

The recent advances in tightly-built residences with low air exchange rates and the increasing interest in the quality of the indoor environment have heightened the awareness of the effects of too much or too little moisture in the home. With the availability of controlled ventilation systems in many tightly constructed homes, moisture levels (indoor relative humidity) can be controlled along with the other indoor air contaminants.

In general, the health effects of indoor moisture have been neglected and are difficult to quantify. Moisture by itself is not a contaninant: it is the biological agents that thrive in moist conditions and the chemicals released through hydrolysis that create moisture-related health problems. 
A recent study investigated the effects of indoor moisture on the accumulation of chemical and biological air contaminants (Sterling et a 1. 1985). The study concluded that high relative humidity promotes the growth of biological organisms such as bacteria, viruses, fungi (mold and mildew), spores, and mites. This phenomenon is particularly acute at indoor relative humidity levels above $60 \%$. The classic exanple of health effects associated with bacteria and viruses associated with moisture in the indoor environment is the outbreak of Legionella pneumonia at a Philadelphia convention in 1976 (ASHRAE 1981).

Sterling et al. 1985 showed that levels of humidity that are either too low or too high will affect human comfort and health. High (>60\%) as well as low $(<40 \%)$ relative humidity levels tended to aggravate allergies in hypersensitive people. Occupants in residences with low relative humidities $(<40 \%)$ tended to have fewer respiratory infections. However, low relative humidity $(<50 \%)$ enhances the formation of ozone indoors. 0zone has an irritating effect on the nose, eyes, and throat. The study concluded that the optimum relative humidity indoors should be between $40 \%$ and $60 \%$ to maintain confort and reduce these health effects.

Table 3.5 shows the range of air exchange rates required to maintain $40 \%$ to $60 \%$ relative humidity at an indoor temperature of $70^{\circ} \mathrm{F}$ in the three prototype structures with occupants that produce 30 ib a day of water vapor. The calculation assumes that the outdoor air is at $32^{\circ} \mathrm{F}$ and $50 \%$ relative humidity. An air exchange rate greater or smaller than the range shown will resul: in either a higher or lower relative humidity respectively. Also, outside air

TABLE 3.5. Air Exchange Rate Required to llaintain 40\% to $60 \%$ Relative Humidity Indoors at $70^{\circ} \mathrm{F}$

\begin{tabular}{|c|c|c|c|}
\hline Structure Type & $\begin{array}{l}\text { Area, } \\
\mathrm{ft}^{2} \\
\end{array}$ & $\begin{array}{l}\text { Volyrie, } \\
\mathrm{ft}^{3}\end{array}$ & $\begin{array}{l}\text { Air Exchange } \\
\text { Rate (ACH) }\end{array}$ \\
\hline single family & 1,540 & 12,320 & $0.12-0.26$ \\
\hline multi-family unit & 600 & 4,800 & $0.32-0.66$ \\
\hline manufactured home & 902 & 7,216 & $0.21-0.44$ \\
\hline
\end{tabular}


that is colder or warmer than $32^{\circ} \mathrm{F}$ will require a greater or smaller air exchange rate, respectively, to maintain the range of 40 to $60 \%$ relative huridity.

In addition to potential health effects described above, excessive moisture indoors (high relative humidity) will cause water vapor to condense on cold surfaces in the winter. This water can cause considerable damage to construction material by accumulating within walls. Severe damage results when the wall surface is penetrated, destroying the studs and reducing the effectiveness of the wall or ceiling insulation.

\subsubsection{Other Health and Safety Concerns}

All design modifications to buildings must conform to building safety codes. Similarly, heating and cooling equipment and cooking appliances must meet national safety standards. These codes reflect the informed judgment of trained, experienced professionals and are specificaliy designed to protect public health and safety. Laboratory testing is usually the basis for information on the expected frequency of adverse impacts for particular energy conservation measures. However, the probability that hazards manifested in the laboratory will actually occur in most buildings is uncertain because combinations of factors not accounted for in the laboratory tests may be involved. In such cases, a conservative approach is usually adopted by the organizations responsible for these codes. That is, the level of requirements generally adopted eliminates or reduces to an acceptable degree all of the likeliest hazards or suspected hazards.

\subsection{OUTDOOR ENVIRONMENTAL IMPACTS}

Building new energy-efficient housing to the proposed voluntary standard would affect the outdoor environment in two ways. The first would be a reduction in the emission of pollutants into the atmosphere from the burning of fossil fuel, either directly by residences with gas, oil or propane heating systerns, or by a reduction in the amount of electricity for new houses with electrical heating/cooling systems generated by fossil-fueled power plants. If it is assumed that the proposed voluntary standard reaches full penetration in 
five years, roughly estimated total annual savings for each of the four fuel types would be $4.7,27.7,1.9$, and $4.0 \mathrm{mill}$ ion Btus for gas, propane, electricity and oil, respectively.

The second effect would resuit from changes in the amount of insulation materials used in the manufacturing of the houses built to the proposed voluntary standard and resultant changes in manufacturing-related emission of outdoor pollutants, primarily suspended particulates. The levels of insulation in houses increased as a result of the VOLRES standard in some case studies (e.g., electrically-heated, single-family residence in Atlanta) and decreased in others (e.g., gas-heated, multi-family residences in winneapolis). Due to the uncertainty of how states with more (or less) stringent current codes will respond to the proposed voluntary standard, no attempt was made to quantify this impact. However, it is estimated that the net effects resulting from changes to insulation production would be very small.

\subsection{ECONONIC IMPACTS}

A detailed economic analysis of the potential impacts of the proposed voluntary standard was conducted, and the results of that analys is are contained in a companion report to this environmental assessment (Marsh et al. 1988). The conclusions of this report concerning estimated direct and indirect economic impacts are sumarized below.

\subsubsection{Direct Economic Inpacts of the Proposed Standard}

The economic analysis of the proposed voiuntary standard for new residertial buildings conciudes that there are no significant adverse effects of adopting the VOLRES standard. The proposed voluntary standard would result in a positive net flow of benefits fron energy savings that more than offset higher capital construction and other costs, when compared to current practice. This conciusion was reached by comparing the life-cycle cost of case study prototypes constructed to currentiy required/used levels, and the cost:; of residences that meet the proposed standard. The incremental costs and benefits of compliance with the voluntary standard were aggregated to reflec: total societal costs and benefits. Increnental costs and benefits to individual homeowners were addressed in the sensitivity analysis only. Differen: 
time horizons, discount rates, and tax effects were used to account for the economic perspective of the homeowner as opposed to that of society as a whole. Aggregated effects were determined for two penetration rate scenarios (i.e., assumptions about the adoption of the VOLRES standard as a mandatory code by the states). Impacts were estimated on the basis of these scenarios for housing starts projected to the year 2005. The major conclusions of the analysis (expressed in constant 1986 dollars) can be sumarized as follows. The national net (societal) effect of the voluntary standard, assuming its immediate and full penetration, ranges from nearly $\$ 930$ million in net benefit for 1988 construction to $\$ 1,035$ million for 1992 construction. This effect is based on the net present value of energy savings and capital costs using a time frame of 15 years. For construction in 1992, the year with the largest net effect, the capital costs of compliance to the standard are $\$ 1.2$ billion. The net present value of energy savings accrued over the 15-year time frame are nearly $\$ 2.2$ bilition. The difference represents a net benefit of $\$ 1.0$ billion for construction in 1992 alone.

Because the standard is voluntary, the net benefits were also calculated assuming penetration of the proposed standard was staged over a five-year period (1988-1992). Full penetration of the voluntary standard does not occur until 1992 in this scenario. The national net effect of the voluntary standard ranges from neariy $\$ 186$ million in net benefit for construction in 1988 to $\$ 1,035$ million for construction in 1995 .

The voluntary standard also creates a net benefit for all regions individually. Assuming full penetration of the voluntary standard, the Northeast receives the greatest annual benefit until 1993, when the net benefits in the South overtake those of the Northeast. The net benefit to the Northeast increases from $\$ 336$ million for 1988 construction to $\$ 384$ billion in 1992 , after which the net benefit drops steadily until the 2001-2005 construction period when it reaches $\$ 220$ million. The West region's net benefit is the smallest of all regional benefits over the study period. Changes in the relative share of net costs and benefits are attributable to forecasted trends in the regional distribution of new housing. 


\subsubsection{Total Economic Impacts of the Proposed Voluntary Standard}

Total impacts (indirect plus direct) were estimated using the 1977 U.S. input-output ( $1 / 0)$ structure of the economy. The difference between capital costs that would be incurred in the construction of the ARES-configured building and those of the buildings constructed according to current practice are introduced as changes in final demands. These changes are then inserted in the I/0 Table to simulate the effect of the direct costs of the voluntary standard on the U.S. economy. The changes in energy expenditures, allocated to the different fuels, are likewise introduced as changes in final demand and used to simulate the changes that result from the proposed standard. These changes in industry output, in turn, are multiplied by labor-intensity for each industry to yield the change in employment that would resuit from the voluntary standard.

The total impacts of the proposed voluntary standard are assessed in terris of the additional output and employment that would result from the increase ir capital costs and the loss of output and employment that would occur due to lower energy expenditures. The total changes resulting from the voluntary standard represent only a very small fraction of the U.S. economy's total output and employment. For purposes of illustration, the effects of the energy savings have been assumed to occur in the year of construction, when in reality the energy savings occur over the fifteen-year time horizon. In 1992, the year with the greatest total impacts, the combined effect of output changes result:; in a net loss of approximately $\$ 2.4$ billion in output due to the effect of the standard. This net decrease in output results from a $\$ 2.3$ billion increase in output resulting from increased capital expenditures for construction and the $\$ 4.7$ billion decrease in output resulting from lower energy expenditures. The greatest total effect on employment results from 1991 construction and shows a loss of 10,800 jobs. This is composed of an increase of 31,800 jobs due to increased capital costs and a loss of 42,600 jobs from decreased energy expenditures.

Even when the combined effects on output resulting fron decreased energy expenditures over the fifteen-year period are assumed to occur in the initial year, the output change represents only 0.05 percent of the U.S. Gross National 
Product. If, in fact, the effects on output due to energy savings were distributed over the fifteen-year period, the loss of output would be greatiy minimized. Concomitantly, the near-term effects (production and employment associated with housing construction) would be increased.

An extensive analysis of the sensitivity of ARES and the resulting lifecycle cost to fuel prices was performed. Fuel prices were increased and decreased by 50 percent in the ARES runs, and the new Tife-cycle cost was calculated for the ARES-configured housing using the increased and decreased fuel prices. As would be anticipated, ARES is sensitive to these major changes in fuel prices. When fuel prices are increased by 50 percent, the net benefit of the proposed voluntary standard increases substantially. The national net benefit reaches its highest level for construction in 1992 with a net benefit of $\$ 2.2$ billion. On the other hand, when fuel prices are decreased by 50 percent, the proposed voluntary standard results in less energy-efficient construction than is currentiy required by many state codes.

The effect of modifying the time horizon used in the ARES program was also tested. The calculation of the net benefit of the proposed voluntary standard with a seven-year time horizon, the proposed voluntary standard would result in a net cost to society in all construction years. Extending the time horizon to 30 years results in a national net benefit that is substantially higher than the net benefit produced by the I5-year time horizon.

The homeowner's perspective was also assessed as part of the sensitivity analysis. For all years of construction, the proposed voluntary standard would generate a net benefit for homeowners (assuming typical 1986 fuel prices).

\subsection{INSTITUTIONAL IMPACTS}

The proposed voluntary standard is intended to be a voluntary guideline for the private sector construction of residential buildings. Because it is not a binding code, there are no institutional impacts that directly result from its issuance by DOE. However, adoption of the proposed voluntary standard as a mandatory code by states and local code entities could have several 
significant institutional effects, discussed below. This discussion is conjectural, since the ultimate use of the VOLRES standard by code jurisdictions and other entities cannot be predicted.

Because of the widespread existence of mandatory energy codes that stipulate minimum ECH levels for new residences, adoption of VOLRES (to update existing codes) is unlikely to adversely impact state and local institutions. This does not imply, however, that adoption would be straightforward or politically uncontroversial. On the contrary, adoption of and changes to state energy codes have often been accompanied by intensive lobbying by the building trades, utilities, homeowner groups, code official organizations and others. Adoption of the VOLRES standard is likely to generate at least as much political controversy as was the case with present state codes. While the large number of user-modifiable parameters in the proposed voluntary standard make it very flexible, this feature also increases the likelihood that when the standard is adopted as a code, it will contain a number of politically-negotiated values for parameters.

In a majority of states with mandatory codes, building eneryy performance requirements are based on average state-wide values for heating and cooling degree days. However, other states attempt to account for climate diversity by designating requirements by climate zone. The most prominent example of the latter is California, where code variations were developed for fourteen zones. The climate zone approach is typically used to strike a balance between two principal (but somewhat contradictory) needs of energy codes--climate sensitivity and simplicity of compliance and enforcement. While the use of zone variations give an energy code more climate sensitivity than a single code, zones also serve to linit the potential geographic variability of requirements that could accompany unrestricted HDo-based performance codes (important to the building trades). The latter need increases the possibilily that states will modify the high climate-related flexibility of the proposed voluntary standard if they choose to adopt it to update current codes.

Adoption of a fuel-specific code such as the VoLRES standard hay also cause some political and institutional impacts in states where energy codes are presently fuel-blind. llost mandatory energy codes do not differentiate between 
energy sources (NCSBCS 1985), although this is becoming an increasingly common approach as states update their codes. Selection of appropriate fuel prices to use in ARES may also prove to be controversial, particularly if VOLRES is adopted on the basis of zones or regions within a state. One final fuelrelated effect may occur. Application of ARES creates separate component packages for different fuels in a given locale (to avoid giving preferential treatment to any fuel). The resulting voluntary standards usually have different ECM requirements and associated life-cycle and construction costs. The cost differences may cause some change in the local narket share held by a given fuel. This so-called "fuel switching" is actually the change in existing patterns of heating fuel choices for new homes by consumers.

Enforcement of the voluntary standard as part of local building codes could require different procedures than those typically used in most states for current energy codes (visual inspection and/or measurenent). Conpliance with the proposed voluntary standard is most easily verified by those methods if the ECH package generated by ARES is used as the code. If other compliance paths (energy budget or point system) are used, code enforcement officials may also need additional training and/or equipment (computers) to deternine compliance. However, the nature and extent of enforcenent-related impacts would depend on the features of the proposed voluntary standard as adopted by state or local governments and the compliance paths that are permitted. 



\subsection{AGENCIES AND PERSONS CONSULTED}

\section{A. STUDY LOCATIONS}

IAMPA, FLORIDA

Ann Stanton

Florida Department of Community Affairs (904) 487-1824

Manuel Zambrano

Building Inspection Department

City of Tampa

(813) 223-8307

Ray Dohle

Tampa Electric Uti]ity

(813) 228-1622

PHOENIX, ARIZONA

Ho-Su Wu

Arizona St. Univ. School of Architecture

(602) $965-3216$

Barney Hunter

Phoenix Construction Code Inspection Office (602) $255-1525$

Michael Melbourne

Melbourne A AsSOC. (Architect)

(602) $955-2100$

Jack Haenicken

Arizona Energy office

(602) $324-3408$

ATLANTA, GEORGIA

Atlanta Building Inspection Department

(404) 658-6336

Clayton County Building Inspection Department

(404) $477-3577$

Chris Savage

Good Cents Program

Georgia Power Co.

(404) 526-7361 
Marvin Black

Construction Contractor

(404) $448-7197$

Jay Wingate

William Howell and Assoc., Architects

(404) $955-5365$

Bob Bagwe 11

Georgia Department of Community Affairs

(404) 656-5529

SEATTLE, WASHINGTON

Woot ie McAdams

Passive Solar Services

(503) 796-9336

John Hogan

City of Seattle

(206) 625-2280

Jim Bowman

Washington State Energy Office

(206) 586-5067

Pete Stuart

King County Building Inspection Department

(206) 296-6600

DENVER, COLORADO

Arlene Quenon

Colorado Homebuilders Association

(303) 758-7575

Don Gisi

Broomfield Building Inspection Department (303) 469-3301

Larry Hanie

Adams County Building Permit Deparment

(303) $287-5249$

John Brann

Denver City Building Inspection Division

(303) $575-5561$

Karen George

Colorado Office of Energy Conservation (303) $866-2507$ 


\section{MINNEAPOLIS, MINNESOTA}

Bruce Nelson

Minnesota Department of Energy and Economic Development

(612) $297-2313$

Wanda Reder

Norther States Power Company

(612) $330-7594$

Minnesota Multi-Family Housing Association

(612) $927-8602$

Minnesota State Homebuilders Association

(612) $646-7959$

FORT WORTH, TEXAS

Dave Patterson

Texas Power and Light

(214) 954-5298

Systems Conservation and Load Management Department

Texas Utilities Electric Co.

(214) 653-4600

Maicolm Verdict

Public Utility Commission of Texas

Energy Efficiency Division

(512) 458-D316

\section{ALBANY, NEW YORK}

Mike DeWein

New York State Energy Office

(518) 474-4995

A)bany City Building Department

(518) $434-5178$

Jack Foley

L.A. Sawyer Construction

(518) $489-4726$

Michaels Group Construction

(518) 783-9641

\section{PROVIDENCE}

Kurt Stenberg, P.E.

Rhode Island State Building Commission

(401) $277-3032$ 
Roger Buck (Consultant)

Rhode Islanders Saving Energy (RISE)

(401) $277-3370$

\section{PASADENA}

\section{Raj Pate1}

Los Angeles County Building Department

(213) $738-2143$

Ted Jones

City of Beverly Hills Buildings Department

(213) 285-1160

Dee Ann Ross

California Energy Commission

916) $324-3408$ 


\section{B. OTHER ENERGY CODE CONTACTS}

CONNECTICUT

John Rucker

Connecticut Energy Division

(203) $568-2800$

Vincent Hidalgo

City of Hartford Building Inspection Department

(203) $722-6370$

IDAHO

Steven D. Benner

Idaho Department of Water Resources

(208) 334-3245

\section{ILLINOIS}

Walter E. Ross

Illinois Department of Energy and Natural Resources

(217) 785-0163

\section{INDIANA}

Tom Jannetides

Energy Conservation Division

Indiana Department of Fire Prevention and

Building Safety

(317) 232-6410

\section{LOUISIANA}

Judy Wright

Louisiana Department of Natural

Resources

Energy Division

(504) $342-7591$

Tony Laska

City of New Orleans

(504) $586-4751$

MARYLAND

Katim Patel

Maryland Department of Economic \& Community Development

Division of Codes Administration

(301) $974-2701$ 


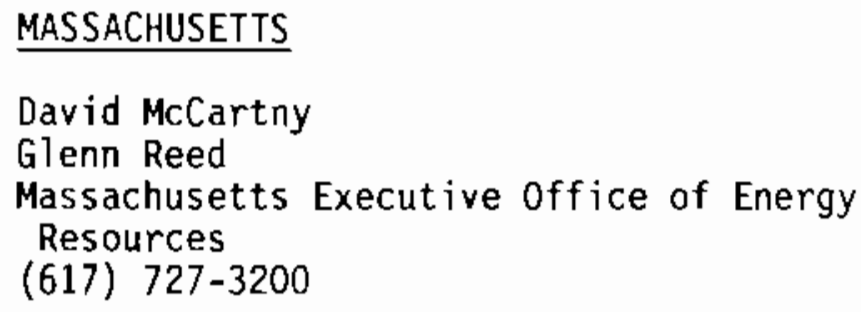

MASSACHUSETTS

David McCartny

Glenn Reed

Massachusetts Executive Office of Energy

Resources

(617) $727-3200$

MICHIGAN

William Lycos

Building Construction Codes

Michigan Department of Labor

(517) $322-1701$

MISSOURI

John A. Buchanan

Community Assistance Program

Missouri Department of

Natural Resources

(314) 751-4000

NEBRASKA

Allison Meyer

Nebraska Energy Office

(402) 471-2867

NEVADA

Jim Hawke, Chief

Energy and Community Development

Nevada State Office of Community Services (702) $885-4420$

NEW JERSEY

Mitch Malec

New Jersey Division of Housing

(609) 292-6364

NORTH CAROLINA

J. Lee Hauser, P.E.

North Carolina Department

of Insurance

(919) 733-3901 
$\underline{\mathrm{OHIO}}$

Abdur Rahim

Energy Efficiency Standards

Ohio Department of Energy

(614) 466-6797

OREGON

Duane Hussey

Oregon Building Codes Division

(503) 373-7902

PENNSYLVANIA

Anthony J. Rametta

Govenor's Energy Counci 1

(717) 783-9981

SOUTH DAKOTA

Steve Wegman

South Dakota Energy Office

(605) 773-3603

\section{TENNESSEE}

Gwenn Harris

Bill Smith

Tennessee Department of Economic and Community Development

Energy Division

Nashville, TN 37219

(615) 741-2994

Steve Soward

Nashville Department of Codes Administration

(615) 259-6719

UTAH

Lee Hathon

Utah Division of Facilities Construction and Management

(801) $533-7744$ 


\section{VIRGINIA}

Gregory Revells

State Office of Uniform Building Code

(804) 786-5041

WISCONSIN

Tom Kasper

Wisconsin Department of Industry, Labor and Human Relations

(608) $266-3152$ 


\subsection{REFERENCES}

Abu-Jarad, F., and J. H. Fremlin. 1981. "The Activity of Radon Oaughters in High-Rise Buildings and the Influence of Soil Emanation." In Indoor Air Pollution. Spengler, J. et al., eds., Proceedings of the Internationat

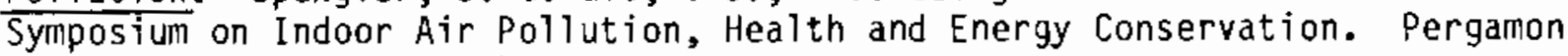
Press, New York, New York.

Andersen, 1. 1979. "Formaldehyde in the Indoor Environment - Health Implications and the Setting of Standards." In Indoor Climate, Effects on Human Comfort, Performance, and Health on Residential, Commercial and LightIndustry Buildings. P. O. Fanger and 0 . Valbjorn, eds., Danish Building Research Institute, Copenhagen.

Anderson, E. W., et al. 1973. "Effect of Low-Level Carbon Monoxide Exposure on Onset and Duration of Angina Pectoris: A Study on 10 Patients with Ischemic Heart Disease." Ann Intern. Med. 79:46-50.

Bouhuys, A., G. J. Beck, and J. B. Schoenberg. 1978. "Do Present Levels of Air Pollution Outdoors Affect Respiratory Health?" Nature. 276:466-471.

Bonneville Power Administration (BPA). 1984. Final Environmental Impact Statement - The Expanded Residential Weatherization Program, Volume 1. DOE/EIS-0095F, U.S. Department of Energy, Washington, D.C.

Bonneville Power Administration (BPA). 1988. Final Environmental Impact Statement on New Energy - Efficient Homes Program Assessing Indoor Air Quality 0ptions. DOE/EIS-0127F, BPA, Portland, Oregon.

Bruno, R. C. 1981. "Source of Indoor Radon in Homes." Paper presented at the International Symposium on Indoor Air Quality, Amherst, Massachusetts.

Cole, et a1. 1983. "Constituent Source Emission Rates Characterization of Three Gas-Fired Domestic Ranges." Presented at the 1983 APCA Annual Meeting, ITT Research Institute and Institute of Gas Technology.

40 CFR 1500-1508. 1985. Council on Environmental Quality, "Regulations for Implementing the Procedural Provisions of the National Environmental Policy Act." U.S. Code of Federal Regulations, Title 40, Parts 1500-1508.

Energy Conservation and Production Act. 1976. Public Law 94-385, 90 Stat. 1144 et. seg., 42 USC 6831.

Energy Conservation Standards for New Buildings Act. 1976. 42 USC 6831 et. seg. (1976).

Ferris, B. G., et a1. 1973. "Chronic Non-Specific Respiratory Disease in Berlin, New Hampshire, 1967-1973 - A Follow-Up Study." Am. Rev. Respir. Dis. 107:110-122. 
Girman, J. R., et al. 1981. "Pollutant Emissions and Source Strengths from Indoor Combustion Appliances and Smoking." Lawrence Berkeley Laboratory, University of California, Berkeley, California.

Girman, J. R., et a?. 1982. "Pollutant Emission Rates from Indoor Combustion Appliances and Sidestream Cigarette Smoke." Environmental International $8: 213-222$.

Greisemer, R. A., et al. 1980. Report of the Federal Pane1 on Formaldehyde. Consumer Product Safety Commission and National Toxicology Program, Washington, D.C.

Grimsrud, D. T., M. H. Sherman and R. C. Sondregger. 1982. Calculating Infiltration: Implications for a Construction Quality Standard. Proceedinss of the ASHRAE-DOE Conference on the Thermal Performance of the Exterior Envelope of Buildings, II, Atlanta, Georgia.

Gupta, K. C., A. G. Ulsamer and P. W. Preuss. 1982. "Formaldehyde in Indoor Air: Sources and Toxicity." Environment International 8:349-358.

Housing and Community Development Act. 1980. Public Law 96-399, Sec. 326, 94 Stat. 1649 .

Kadulski, Richard. Residential Ventilation: Acheiving Indoor Air Quality. The Drawing-Room Graphics Services Ltd. North Vancouver, British Columbia VTL 4L2. 1988.

Lawrence Berkeley Laboratory. Undated. Affordable Housing Through Energy Conservation, Technical Support Document. Lawrence Berkeley Laboratory, Berkeley, California.

Lawther, P. J., R. E. Waller, and M. Henderson. 1970. "Air Pollution and Exacerbations of Bronchitis." Thorax 25:525-539.

Lunn, J. E., J. Knowelden and A. J. Handyside. 1967. "Patterns of Respiratory Iliness in Sheffield Infant Schoolchildren." Br. J. Prev. Soc. Med. $21: 7-16$.

"Manufactured Home Construction and Safety Standards," 49 Fed. Reg. 31996-32013 (August 9, 1984).

Meyer, B. 1983. Indoor Air Quality. Addision-Wesley Publishing Company, Inc., Reading, tlassachusetts.

Miksch, R. R., C. D. Hollowell, and H. E. Schmidt. 1982. "Trace Organic Contaminants in office Spaces." Environmental International 8:129-137.

Molhave, L. 1982. "Indoor Air Pollution Due to Organic Gases and Vapors of Solvents in Building Materials." Environmental International 8:117-127. 
National Academy of Sciences (NAS). 1980. Formaldehyde--An Assessment of Its Health Effects. Committee on Toxicology, National Academy Press, Washington, D.C.

National Appliance Efficiency Conservation Act. 1987. Public Law 100-12, 42 USC 6201.

National Conference of States on Building Codes and Standards, Inc. 1985. Directory and Completion of technical and Administrative Requirements in Energy Codes for New Building Construction Used Within the United States (Revised). Herndon, Virginia.

National Environmental Policy Act. 1969. Public Law 91-190, as amended. 42 USC 4321 et. seq..

National Research Council. 1981a. Indoor Pollutants. National Academy Press, Washington, D.C.

National Research Council. 1981b. Formaldehyde and Other Aldehydes. National Academy Press, Washington, D.C.

Nesse, R. J., J. W. Callaway, R. F. Darwin, A. D. Lee and S. A. Harkrender. 1988. Analysis of Alternative Housing Energy Standards. PNL-6406, Pacific Northwest Laboratory, Richland, Washington.

Omnibus Reconciliation Act. 1981. Public Law 97-35, 95 Stat. 621.

"Position Paper on Legionellosis." Presented at the 1981 Summer Meeting of the American Society of Heating Refrigerating and Air Conditioning Engineers, Atlanta, Georgia, May 2, 1981.

Proceedings of the Building Sciences Insight ' 83 . Humidity, Condensation and Ventilation in Houses. National Research Council of Canada, Division of Building Research Ottawa, Ontario Canada K1A 0R6. May, 1984.

Sachs, H. M., T. L. Hernandez and J. W. Ring. 1982. "Regional Geology and Radon Variabitity in Buildings." Environmental International 8:97-104.

Sterling, E. M., Arundel, A. and Sterling, T. D. "Criteria for Human Exposure to Humidity in Occupied Buildings" ASHRAE Transactions 1985, V.91, Pt.1B. $611-621$.

Steven Winter Associates, Inc. 1983. Affordable Manufactured Housing Through Energy Conservation, Technical Support Document. Steven Winter Associates, Inc., New York, New York.

U.S. Department of Energy (DOE). 1986. Final Environmental Assessment, Proposed Interim Conservation Standard for the Design of New Federal Commercial Buildings. U.S. Department of Energy, Washington, D.C. 
U.S. Department of Energy (DOE). 1983. Federal Ten-Year Buildings Plan. DOE/CE-0047, U.S. Department of Energy, Washington, D.C.

U.S. Department of Energy Organization Act, Public Law 95-91, 42 USC, Sec. 7154 (August 4, 1977).

U.S. Environmenta? Protection Agency (EPA). 1980. "Interim and Proposed Cleanup Standard for Buildings Contaminated by Uranium Processing Sites." FR 45:27366-27375.

U.S. Environmental Protection Agency (EPA). 1982. "Review of the National Ambient Air Quality Standards for Particulate Matter: Assessment of Scientific and Technical Information." Office of Air Quality Planning and Standards, U.S. Environmental Protection Agency, Research Triangle Park, North Carolina.

Wadden, R. A., and P. A. Scheff. 1983. Indoor Air Pollution: Characterization, Prediction, and Control. John Wiley \& Sons, New York, New York.

Walsh, P. J., C. S. Dudney, and E. D. Copenhaver (eds.). 1984. Indoor Air Quality. CRC Press, Inc., Boca Raton, Florida.

Yocom, J. E. 1982. "Indoor-Outdoor Air Quality Relationships, a Critical Review." J. of the Air Pollution Control Assoc. 32:500. 
APPENDIX A

DESCRIPTION DF CASE-STUDY RESIDENCES UNDER THE PROPOSED STANDARD 
APPENDIX A

\section{DESCRIPTION OF CASE-STUDY RESIDENCES UNDER THE PROPOSED STANDARD}

\section{A.1 SELECTION OF THE CASE STUDY RESIDENCES}

Over seventy case study hones were created for this analysis using the Automated Residential Energy Standard (ARES) software to deternine ECil levels that would meet the proposed voluntary standard. These case study homes cover three types of residential housing, up to five fuel/heating appliance specifications and ten locations. In addition, each case study for site built homes included insulation requirements for four alternative foundations. Considerations used to select the residences to be studied included the following:

Building Prototypes. The ARES software produces voluntary standards for three types of residential structures: single family and multi-fanily sitebuilt homes and sing?e-wide manufactured (mobile) homes. Each type is represented as a generic, relatively simple prototype, with set dimensions and features. Each site-built prototype also comes with several foundation options, while the manufactured home is modeled only on the crawl space foundations. Packages of energy conservation measures (ECMs) generated by the voluntary standard show required insulation levels for each foundation type selected for consideration by the user. Tables A.1 and A.2 list the building types, their dimensions, and the foundation options that were studied in this analysis. Voluntary standards were created for all four foundation variations for the site-built prototypes, and indoor air quality effects were estinated for each of those variations. Although the economic analysis was based on those same prototypes, a somewhat different approach to determine impacts. In that study, aggregate impacts were determined by deriving regional allocations of each foundation type (U.S. Department of Commerce 1986) for single and multifamily residences. Regional costs and benefits and the national total were determined on the basis of those distributions. 


\section{TABLE A.1. Prototype Residential Units}

\begin{tabular}{lll}
\multicolumn{1}{c}{ House Type } & & \multicolumn{1}{c}{ Foundation Type } \\
\hline 1) single-family residence & & crawl space \\
2) single-family residence & & unconditioned basement \\
3) single-family residence & conditioned basement \\
4) single-family residence & slab \\
5) multi-family residence & crawl space \\
6) multi-family residence & unconditioned basement \\
7) multi-family residence & conditioned basement \\
8) multi-family residence & slab \\
9) manufactured home & crawl space
\end{tabular}

TABLE A.2. Residential Housing - Selected Unit Dependent Characteristics

\begin{tabular}{lrrr}
\multicolumn{1}{c}{ Component } & $\begin{array}{c}\text { Single } \\
\text { Family }\end{array}$ & $\begin{array}{c}\text { Multi- } \\
\text { Family }\end{array}$ & $\begin{array}{c}\text { Manu. } \\
\text { Home }\end{array}$ \\
\cline { 1 - 2 } ceiling square feet & 1540 & 600 & 902 \\
wall square feet & 1328 & 640 & 1162 \\
floor square feet & 1540 & 600 & 902 \\
slab perimeter linear feet & 166 & 40 & NA \\
basement wall perimeter linear feet & 166 & 40 & NA
\end{tabular}

Case Study Locations. Ten cities distributed across the continental United States were selected as locations where VOLRES would be compared to existing energy efficiency-related building practices and requirements. These locations represent a range of heating and cooling degree day values that span the predominant climatic conditions in the United States. Regions where new residential construction has been and is expected to be particularly heavy were slightly emphasized in the selection of the locations. Table A.3 shows the cities that were selected for this analysis. 
TABLE A.3. Locations and Fuels Examined in the Assessment

\begin{tabular}{|c|c|c|c|c|c|c|c|c|}
\hline \multirow[b]{2}{*}{ Location } & \multirow{2}{*}{\multicolumn{4}{|c|}{$\begin{array}{l}\text { Single and Multi-Family } \\
\text { Gas Elect. HP Oil }\end{array}$}} & \multicolumn{4}{|c|}{ Manufactured Homes } \\
\hline & & & & & Gas & Ele & $\angle P G$ & $0 i 1$ \\
\hline Atlanta & $x$ & $x$ & $x$ & & $x$ & $x$ & $x$ & \\
\hline Denver & $x$ & $x$ & $x$ & & $x$ & $x$ & $x$ & \\
\hline Fort Worth & $x$ & $x$ & $x$ & & $x$ & $x$ & $x$ & \\
\hline Ifinneapolis & $x$ & $x$ & $x$ & & $x$ & $x$ & $x$ & \\
\hline Pasadena & $x$ & $x$ & $x$ & & $x$ & $x$ & $x$ & \\
\hline Phoenix & $x$ & $x$ & $x$ & & $x$ & $x$ & $x$ & \\
\hline Seattle & $x$ & $x$ & $x$ & & $x$ & $x$ & $x$ & \\
\hline Tampa & $x$ & $x$ & $x$ & & $x$ & $x$ & $x$ & \\
\hline Albany & $x$ & $x$ & $x$ & $x$ & $x$ & $x$ & $x$ & $x$ \\
\hline Providence & $x$ & $x$ & $x$ & $x$ & $x$ & $x$ & $x$ & $x$ \\
\hline
\end{tabular}

Fuels. The voluntary standards generated for VOLRES by the ARES sof tware are specific to the fuel/heating appliance combinations selected by the user from among the five choices provided in the ARES program. In order to somewhat limit the number of voluntary standards at each location, it was decided to develop VOLRES standards for only the two predominant heating fuels in each city. (When electricity was one of those fuels, however, there actually were three variations of the voluntary standard created, since ARES creates separate requirements for electric forced-air and electric heat-punp appliances.) Baseline residences were also modeled using only the two predominant heating fuels, except as noted below. The two primary heating fuels were selected using data from recent Bureau of Census New Housing Construction reports that showed the distribution by heating fuels of recently constructed new homes. In two locations (Albany and Providence), a third fuel (electricity) was also considered because of its widespread use as a heating source for multi-fanily housing. Table A.3 shows the fuels selected for each location. 


\section{A.2 GENERATION OF ECM LEVELS FOR THE CASE-STUDY RESIDENCES}

Generation of the ECM package with the ARES software requires the user to make a number of choices that tailor the voluntary standard to local conditions, prices, and construction trends. The choices that were used to deveiop the proposed voluntary standard case study homes are listed below.

Fuel Prices. Prices used for selected fuels were current (1986) locationspecific prices obtained from published sources. The primary source of naturat gas and fuel oil prices for each study location was the Annual Househeating Survey published by the Anerican Gas Association (AGA 1986). Electricity prices were obtained from The Electrical World Directory of Electric Utilities, 1985-1986 94th Edition, (McGraw-Hill 1987). Fuel oil and LPG prices were obtained from the State Energy Price and Expenditure Report, 1985, pubTished by the Energy Information Administration (1987). Sensitivity of ARES output to variations in fuel price were studied extensively in the economic analysis. Results of the fuel price sensitivity analysis are included in Section 3.5 .

Construction Costs. The ARES program contains resident data bases with average ECII construction costs (1986 dollars) for eleven regions covering the continental United States. These costs are default values that can be nodified by individual users of the software. For the purpose of this study, no changes were made to the defauit values, which were set by the ASHRAE Technical Evaluation Committee of Special Project 53.

ECM and Heating Appliance Efficiencies. The life-cycle minimization process assesses a variety of envelope ECMs, HVAC systems and their associated energy efficiency and costs. For example, the ARES program can examine the relative cost-effectiveness of six levels of ceiling insulation thicknesses (with efficiencies ranging from $R-11$ to $R-60$ ). Appliance efficiency values in ARES are not aliowed to drop below the mininum efficiencies mandated in the National Appliance Energy Conservation Act. (NAECA) of 1987 (42 USC 6201). However, the software can select higher efficiencies, if the life cycle cost of the hone can be lowered by doing so. Minimur efficiencies allowable under NAECA become mandatory between 1990 and 1932 (the date varies by type of 
appliance) for new space conditioning equipment. The NAECA minimun values were used to develop the comparative life-cycle costs and energy use of the baseline (current code) prototypes.

Windows. Users of the ARES program can set the amount (window-to-floorarea ratio) and percent of south-facing fenestration (except in manufactured housing) in the prototypes. Users can also limit the types of glazing that are to be considered in creating the voluntary standard. llodifying any of these parameters often produces adjustments in the required efficiency of other ECMs. The proposed voluntary standard and baseline case study residences were created by using the following parameters: 1) window area was set at 12 percent of floor area; 2) one-fourth of the window area was placed on the southfacing wa11; and 3) ARES was not allowed to consider single pane/thernal break, triple pane/no thermal break, and reflective low emissivity (low E-sun) glazing options for the windows. While those types of glazing are commercially available, they are not yet widely marketed for residential construction and are seldom used by builders (although low E-reflective glazing is becoming more popular in sunbelt states). (a)

Economic Parameters. ARES contains a file listing the economic parameters that guide its life-cycle cost calculations. In conjunction with other files and programing, the software generates the package of ECM components that represents minimized building life-cycle cost in any location. The user can edit the initial (default) values assigned to these econonic paraneters. A slightly different voluntary standard often results from such changes. For the purposes of this assessment, the default values for the economic parameters (shown in Table A.4) were used. The economic parameters used for the analysis of manufactured housing were changed in some cases to more accurately reflect nanufactured home buyers' environment. Extensive sensitivity testing of important variables (e.g., the discount rate) was conducted as part of the economic analysis.

(a) Telephone conversation between Todd Taylor, Pacific Northwest Laboratory, and Steve Selkowitz, Lawrence Berkeley Laboratory, March 15, 1988. 
TABLE A.4. Economic Parameters Used to Create Case Study Residences

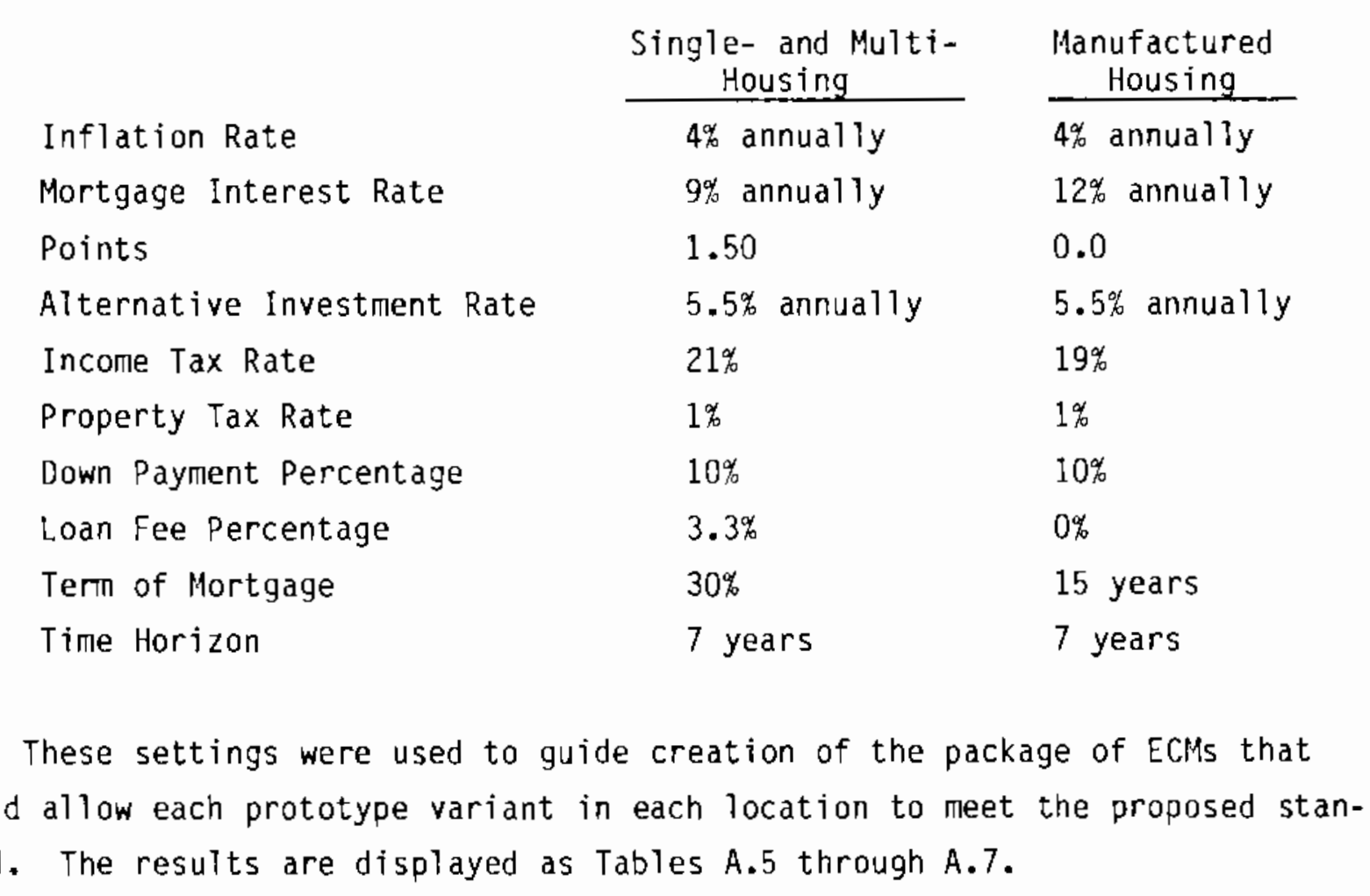


TABLE A. 5 Description of Prototype $\mathrm{ECM}^{\prime} \mathrm{s}$ for the Single Family Residence

\begin{tabular}{|c|c|c|c|c|c|c|c|c|c|c|}
\hline & & $\begin{array}{c}\text { Base Line } \\
\text { Tampa } \\
\end{array}$ & $\begin{array}{l}\text { Ares } \\
\text { Tampa } \\
\end{array}$ & $\begin{array}{l}\text { Change In } \\
\text { Insulation } \\
\text { (inches) } \\
\text { FG Sheath }\end{array}$ & $\begin{array}{l}\text { Base Line } \\
\text { Phoenix } \\
\end{array}$ & $\begin{array}{c}\text { Ares } \\
\text { Phoenix } \\
\end{array}$ & $\begin{array}{l}\text { Change In } \\
\text { Insulation } \\
\text { (inches) } \\
\text { FG Sheath }\end{array}$ & $\begin{array}{l}\text { Base Line } \\
\text { Atlanta }\end{array}$ & $\begin{array}{c}\text { Ares } \\
\text { Atlanta }\end{array}$ & $\begin{array}{l}\text { Change In } \\
\text { Insulation } \\
\text { (inches) } \\
\text { FG Sheath } \\
\end{array}$ \\
\hline Gas & $\begin{array}{l}\text { ceiling insulation } \\
\text { wall insulation } \\
\text { crawlspace insulation } \\
\text { base. floor insulation } \\
\text { base. wall insulation } \\
\text { slab insulation } \\
\text { glazing type } \\
\text { infiltration } \\
\text { heating efficiency } \\
\text { cooling efficiency }\end{array}$ & $\begin{array}{l}R-19 \\
R-11 \\
R-8 \\
R-0 \\
R-0 \\
R-0 \\
S W / 0 \text { tb } \\
\text { normal } \\
\text { AFUE } 78 \% \\
\text { SEER } 10\end{array}$ & $\begin{array}{l}R-19 \\
R-11 \\
R-0 \\
R-0 \\
R-0 \\
R-0 \\
\text { ObL } H / O \text { tb } \\
\text { nOImal } \\
\text { AFUE } 78 \% \\
\text { SEER } 10\end{array}$ & $\begin{array}{l}0.0 \\
0.0 \\
0.0 \\
0.0 \\
0.0 \\
0.0\end{array}$ & $\begin{array}{l}R-30 \\
R-19 \\
R-11 \\
R-0 \\
R-0 \\
R-0 \\
\text { S-W/O to } \\
\text { nORInal } \\
\text { AFUE } 78 \% \\
\text { SEER 10 }\end{array}$ & $\begin{array}{l}R-19 \\
R-13 \\
R-13 \\
R-0 \\
R-5=4 \mathrm{ft} \\
R-0^{-} \\
\text {ObL w/o tb } \\
\text { norma! } \\
\text { AFUE } 78 \% \\
\text { SEER } 10\end{array}$ & $\begin{array}{r}-6.5 \\
-2.0 \\
0.5 \\
0.0 \\
1.0 \\
0.0\end{array}$ & $\begin{array}{l}R-19 \\
R-11 \\
R-11 \\
R-11 \\
R-0 \\
R-52 \text { ft } \\
\text { S } 1 / 0 \text { tb } \\
\text { normal } \\
\text { AFUE } 78 \% \\
\text { SEER } 10\end{array}$ & $\begin{array}{l}R-30 \\
R-23 \\
R-19 \\
R-11 \\
R-0 \\
R-0 \\
\text { Dbl } H / 0 \text { tb } \\
\text { normal } \\
\text { AFUE } 90 \% \\
\text { SEER } 10\end{array}$ & $\begin{array}{l}6.5 \\
2.51 .0 \\
2.5 \\
0.0 \\
0.0 \\
-1.0\end{array}$ \\
\hline $\begin{array}{l}\text { Electric } \\
\text { Forced } \\
\text { Air }\end{array}$ & $\begin{array}{l}\text { ceiling insulation } \\
\text { wall insulation } \\
\text { crawlspace insulation } \\
\text { base. floor insulation } \\
\text { base. Hall insulation } \\
\text { slab insulation } \\
\text { glazing type } \\
\text { infiltration } \\
\text { heating efficency } \\
\text { cooling efficiency }\end{array}$ & $\begin{array}{l}R-30 \\
R-11 \\
R-0 \\
R-0 \\
R-0 \\
R=0 \\
S \text { W/o tb } \\
\text { normal } \\
- \\
\text { SEER } 10\end{array}$ & $\begin{array}{l}R-19 \\
R-19 \\
R-11 \\
R-0 \\
R-0 \\
R-0 \\
\text { Dbl w/o tb } \\
\text { nonmal } \\
- \\
\text { SEER } 10\end{array}$ & $\begin{array}{r}-6.5 \\
2.5 \\
3.5 \\
0.0 \\
0.0 \\
0.0\end{array}$ & $\begin{array}{l}R-30 \\
R-19 \\
R-11 \\
R-0 \\
R-0 \\
R-0 \\
\text { S_W/o tb } \\
\text { normal } \\
\quad- \\
\text { SEER } 10\end{array}$ & $\begin{array}{l}R-38 \\
R-23 \\
R-30 \\
R-19 \\
R-104 \mathrm{ft} \\
R-5=-2 \mathrm{ft} \\
\text { Dbl-Low-e } \\
\text { normal } \\
\quad- \\
\text { SEER } 10\end{array}$ & $\begin{array}{l}3.5 \\
0.0 \\
5.5 \\
6.0 \\
2.0 \\
1.0\end{array}$ & $\begin{array}{l}R-19 \\
R-11 \\
R-11 \\
R-11 \\
R-0 \\
R-5 \text { 2 ft } \\
S \text { W/o tb } \\
\text { normal } \\
- \\
\text { SEER } 10\end{array}$ & $\begin{array}{l}R-49 \\
R-26 \\
R-30 \\
R-30 \\
R-104 \mathrm{ft} \\
R-5=\frac{\mathrm{ft}}{} \\
\text { Dbl_Low-e } \\
\text { normal } \\
- \\
\text { SEER } 10\end{array}$ & $\begin{array}{l}14.5 \\
2.52 .0 \\
5.5 \\
5.5 \\
2.0 \\
0.0\end{array}$ \\
\hline $\begin{array}{l}\text { Flectric } \\
\text { Heat } \\
\text { Pump }\end{array}$ & $\begin{array}{l}\text { ceiling insulation } \\
\text { wall insulation } \\
\text { crawlspace insulation } \\
\text { base. floor insulation } \\
\text { base. Wall insulation } \\
\text { slab insulation } \\
\text { glazing type } \\
\text { infiltration } \\
\text { heating efficiency } \\
\text { cooling efficiency }\end{array}$ & $\begin{array}{l}R-30 \\
R-11 \\
R-0 \\
R-0 \\
R-0 \\
R=0 \\
S \text { W/o tb } \\
\text { normal } \\
\text { HSPF } 7.3 \\
\text { SEER } 10\end{array}$ & $\begin{array}{l}R-19 \\
R-1 \\
R-0 \\
R-0 \\
R-0 \\
R-0 \\
\text { Db! w/o tb } \\
\text { norma! } \\
\text { HSPF } 7.3 \\
\text { SEER } 10\end{array}$ & $\begin{array}{l}-6.5 \\
0.0 \\
0.0 \\
0.0 \\
0.0 \\
0.0\end{array}$ & $\begin{array}{l}R-30 \\
R-19 \\
R-11 \\
R-0 \\
R-0 \\
R-0 \\
\text { S_H/o tb } \\
\text { r.ormal } \\
\text { HSPF } 7.3 \\
\text { SEER } 10\end{array}$ & $\begin{array}{l}R-30 \\
R=13 \\
R-30 \\
R-0 \\
R-5{ }^{-4} \mathrm{ft} \\
R-0^{-} \\
\text {Dbl_lon-e } \\
\text { normal } \\
\text { HSPF } 7.3 \\
\text { SEER } 10\end{array}$ & $\begin{array}{r}0.0 \\
-2.0 \\
5.5 \\
0.0 \\
1.0 \\
0.0\end{array}$ & 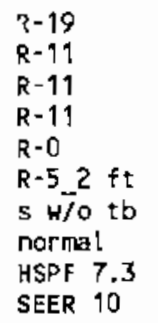 & $\begin{array}{l}R-30 \\
R-23 \\
R-30 \\
R-11 \\
R-10 \_4 \mathrm{ft} \\
R-5, \overrightarrow{2} \mathrm{ft} \\
\text { Dbl }-\mathrm{H} / \mathrm{o} \text { tb } \\
\text { nOrmal } \\
\text { HSPF } 7.3 \\
\text { SEER } 10\end{array}$ & $\begin{array}{ll}6.5 & \\
2.5 & 1.0 \\
5.5 & \\
0.0 & \\
2.0 & \\
0.0 & \end{array}$ \\
\hline oil & $\begin{array}{l}\text { house type } \\
\text { heat eq. type } \\
\text { ceiling insulation } \\
\text { wall insulation } \\
\text { crawlspace insulation } \\
\text { base. floor insulation } \\
\text { base. wall insulation } \\
\text { slab insulation } \\
\text { glazing type } \\
\text { infiltration } \\
\text { heating efficiency } \\
\text { cooling efficiency }\end{array}$ & NA & NA & & NA & $\mathrm{NA}$ & & NA & NA & \\
\hline
\end{tabular}




\section{IABLE A.5 (Cont.)}

\begin{tabular}{|c|c|c|c|c|c|c|c|c|c|c|}
\hline & & $\begin{array}{l}\text { Base Line } \\
\text { Seattle }\end{array}$ & $\begin{array}{c}\text { Ares } \\
\text { Seattle } \\
\end{array}$ & $\begin{array}{l}\text { Change In } \\
\text { Insulation } \\
\text { (inches) } \\
\text { FG Sheath }\end{array}$ & $\begin{array}{l}\text { Base Line } \\
\text { Denver }\end{array}$ & $\begin{array}{c}\text { Ares } \\
\text { Denver }\end{array}$ & $\begin{array}{l}\text { Change in } \\
\text { Insulation } \\
\text { (inches) } \\
\text { FG Sheath }\end{array}$ & $\begin{array}{l}\text { Base Line } \\
\text { Minneapol }\end{array}$ & $\begin{array}{c}\text { Ares } \\
\text { Minneapol }\end{array}$ & $\begin{array}{l}\text { Change In } \\
\text { insulation } \\
\text { (inches) } \\
\text { FG Sheath }\end{array}$ \\
\hline Gas & $\begin{array}{l}\text { cejling insulation } \\
\text { wall insulation } \\
\text { crawlspace insulation } \\
\text { base. floor insulation } \\
\text { base. wall insulation } \\
\text { slab insulation } \\
\text { glazing type } \\
\text { infiltration } \\
\text { heating efficiency } \\
\text { cooling efficiency }\end{array}$ & $\begin{array}{l}R-30 \\
R-11 \\
R-19 \\
R-19 \\
R-5-2 \mathrm{ft} \\
R-5-2 \mathrm{ft} \\
\text { Dbi W/o tb } \\
\text { nOrma! } \\
\text { AFUE- } 85 \% \\
\text { SEER-10 }\end{array}$ & $\begin{array}{l}R-30 \\
R-23 \\
R-30 \\
R-19 \\
R-0 \\
R-522 \mathrm{ft} \\
\text { Obl W/O tb } \\
\text { NOFMal } \\
\text { AFUE } 85 \% \\
\text { SEER } 10\end{array}$ & $\begin{array}{r}0.0 \\
2.51 .0 \\
3.0 \\
0.0 \\
-1.0 \\
0.0\end{array}$ & $\begin{array}{l}R-30 \\
R-13 \\
R-13 \\
R-13 \\
R-5-2 f t \\
R-5-2 \mathrm{ft} \\
\text { Dbl w/o-tb } \\
\text { nOrma } L \\
\text { AFUE- } 80 \% \\
\text { SEER- LO }\end{array}$ & $\begin{array}{l}R-30 \\
R-23 \\
R-13 \\
R-1 ! \\
R-104 \mathrm{ft} \\
R-5-2 \mathrm{ft} \\
\text { Dbl } \mathrm{H} / 0 \mathrm{tb} \\
\text { nOFmal } \\
\text { AFUE } 80 \% \\
\text { SEER } 10\end{array}$ & $\begin{array}{l}0.0 \\
2.0 \quad 1.0 \\
0.0 \\
-0.5 \\
1.0 \\
0.0\end{array}$ & $\begin{array}{l}R-38 \\
R-19 \\
R-19 \\
R-19 \\
R-5=2 \mathrm{ft} \\
R-5-2 \mathrm{ft} \\
\text { DbL_tb } \\
\text { norma! } \\
\text { AFUE } 78 \% \\
\text { SEER-10 }\end{array}$ & $\begin{array}{l}R-30 \\
R-23 \\
R-30 \\
R-13 \\
R-1044 \mathrm{ft} \\
R-5=2 \mathrm{ft} \\
\text { Dbl_low-e } \\
\text { nOrmal } \\
\text { AFUE } 90 \% \\
\text { SEER } 10\end{array}$ & $\begin{array}{rl}-3.5 & \\
0.0 & 1.0 \\
3.0 & \\
-2.0 & \\
1.0 & \\
0.0 & \end{array}$ \\
\hline $\begin{array}{l}\text { Electric } \\
\text { Forced } \\
\text { Air }\end{array}$ & $\begin{array}{l}\text { ceiling insulation } \\
\text { wall insulation } \\
\text { crawlspace insulation } \\
\text { base. flaor insulation } \\
\text { base. Wall insulation } \\
\text { slab insulation } \\
\text { glazing typo } \\
\text { infiltration } \\
\text { heating efficiency } \\
\text { cooling efficiency }\end{array}$ & $\begin{array}{l}R-38 \\
R-19 \\
R-19 \\
R-19 \\
R-5=2 \mathrm{ft} \\
R-5-2 \mathrm{ft} \\
\text { DbL_tb } \\
\text { normal } \\
- \\
\text { SEER L } 10\end{array}$ & 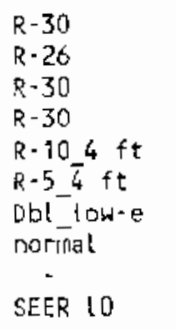 & $\begin{array}{l}-3.5 \\
0.02 .0 \\
3.0 \\
3.0 \\
1.0 \\
0.0\end{array}$ & $\begin{array}{l}R-30 \\
R-13 \\
R-13 \\
R-13 \\
R-5 \_\mathrm{ft} \\
R-5 \_2 \mathrm{ft} \\
D b-W / 0-\mathrm{tb} \\
\text { nORmal } \\
\quad- \\
\text { SEER- } 10\end{array}$ & 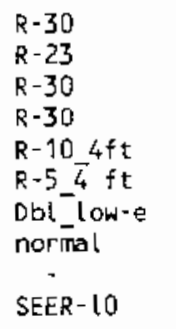 & $\begin{array}{l}0.0 \\
2.0 \\
5.0 \\
5.0 \\
1.0 \\
0.0\end{array}$ & $\begin{array}{l}R-38 \\
R-19 \\
R-19 \\
R-19 \\
R-5=2 \mathrm{ft} \\
R-5=2 \mathrm{ft} \\
\text { Dbl_tb } \\
\text { normal } \\
- \\
\text { SEER-10 }\end{array}$ & $\begin{array}{l}R-30 \\
R-26 \\
R-30 \\
R-30 \\
R-104 \mathrm{ft} \\
R-5-\frac{\mathrm{ft}}{} \\
\text { Ob! L L OH-e } \\
\text { normal } \\
- \\
\text { SEER } 10\end{array}$ & $\begin{array}{rl}-3.5 & \\
0.0 & 2.0 \\
3.0 & \\
3.0 & \\
1.0 & \\
0.0\end{array}$ \\
\hline $\begin{array}{l}\text { Electric } \\
\text { Heat } \\
\text { Pum }\end{array}$ & $\begin{array}{l}\text { ceiling insulation } \\
\text { wall insulation } \\
\text { crawlspace insulation } \\
\text { base. floor insulation } \\
\text { base. Wall insulation } \\
\text { slab insulation } \\
\text { glazing type } \\
\text { infiltration } \\
\text { heating efficiency } \\
\text { cooling efficicncy }\end{array}$ & $\begin{array}{l}R-30 \\
R-13 \\
R-19 \\
R-19 \\
R-5-2 \mathrm{ft} \\
R-5=2 \mathrm{ft} \\
\text { Dbl } \mathrm{H} / 0 \text { to } \\
\text { nOIMal } \\
\text { HSPF } 7.3 \\
\text { SEER } 10.0\end{array}$ & $\begin{array}{l}R-30 \\
R-23 \\
R-30 \\
R-16 \\
R-0 \\
R-5=2 \mathrm{ft} \\
D B L \text { W/O tb } \\
\text { nOrmal } \\
\text { HSPF } 7.3 \\
\text { SEER } 10.0\end{array}$ & $\begin{array}{l}0.0 \\
2.01 .0 \\
3.0 \\
-2.5 \\
1.0 \\
0.0\end{array}$ & $\begin{array}{l}R-30 \\
R-13 \\
R-13 \\
R-13 \\
R-5=2 \mathrm{ft} \\
R-5=2 \mathrm{ft} \\
\text { DbL } \mathrm{W} / \mathrm{o}^{-\mathrm{tb}} \\
\text { nOrmal } \\
\text { HSPF } 7.3 \\
\text { SEER } 10.0\end{array}$ & $\begin{array}{l}R-30 \\
R-23 \\
R-30 \\
R-30 \\
R-10-4 \mathrm{ft} \\
R-10-2 \mathrm{ft} \\
\text { DbL Tow-e } \\
\text { nORMal } \\
\text { HSPF } 7.3 \\
\text { SEER } 10.0\end{array}$ & $\begin{array}{l}0.0 \\
2.0 \\
5.0 \\
5.0 \\
1.0 \\
1.0\end{array}$ & $\begin{array}{l}R-38 \\
R-19 \\
R-19 \\
R-19 \\
R-522 \mathrm{ft} \\
R-5=2 \mathrm{ft} \\
\text { DbL_tb } \\
\text { normal } \\
\text { HSPF } 7.3 \\
\text { SEER } 10.0\end{array}$ & $\begin{array}{l}R-30 \\
R-23 \\
R-30 \\
R-30 \\
R-104 \mathrm{ft} \\
R-5-\frac{\mathrm{ft}}{4} \\
\text { DbL }-1 \mathrm{CH}-\mathrm{e} \\
\text { nOFmal } \\
\text { HSPF } 9.8 \\
\text { SEER } 12.0\end{array}$ & $\begin{array}{r}-3.5 \\
0.01 .0 \\
3.0 \\
3.0 \\
1.0 \\
0.0\end{array}$ \\
\hline oil & $\begin{array}{l}\text { cciling insulation } \\
\text { wall insulation } \\
\text { crawlspace insulation } \\
\text { base. floor insulation } \\
\text { base. Hall insulation } \\
\text { slab insulation } \\
\text { glazing type } \\
\text { infiltration } \\
\text { heating efficiency } \\
\text { cooling efficiency }\end{array}$ & NA & NA & & NA & NA & & NA & NA & \\
\hline
\end{tabular}




\section{TABLE A.5 (Cont.)}

\begin{tabular}{|c|c|c|c|c|c|c|c|c|c|c|}
\hline & & $\begin{array}{l}\text { Base Line } \\
\text { Ft Worth }\end{array}$ & $\begin{array}{c}\text { Ares } \\
\text { Ft Worth }\end{array}$ & $\begin{array}{l}\text { Change In } \\
\text { insulation } \\
\text { (inches) } \\
\text { FG Sheath }\end{array}$ & $\begin{array}{l}\text { Base Line } \\
\text { Albany }\end{array}$ & $\begin{array}{c}\text { Ares } \\
\text { Albany } \\
\end{array}$ & $\begin{array}{l}\text { Change In } \\
\text { Insulat ion } \\
\text { (inches) } \\
\text { FG Sheath }\end{array}$ & $\begin{array}{l}\text { Base Line } \\
\text { Providence }\end{array}$ & $\begin{array}{c}\text { Ares } \\
\text { Providence (a) }\end{array}$ & $\begin{array}{l}\text { Change In } \\
\text { Insulation } \\
\text { (inches) } \\
\text { FG Sheath }\end{array}$ \\
\hline Gas & $\begin{array}{l}\text { ceiling insulation } \\
\text { wall insulation } \\
\text { craslspace insulation } \\
\text { base. floor insulation } \\
\text { base. wall insulation } \\
\text { slab insulation } \\
\text { glazing type } \\
\text { infiltration } \\
\text { heating efficiency } \\
\text { cooling efficiency }\end{array}$ & $\begin{array}{l}R-19 \\
R-13 \\
R-13 \\
R=0 \\
R-0 \\
R-0 \\
\text { Dbl th } \\
\text { norinal } \\
\text { AFUE } 79 \% \\
\text { SEER-10 }\end{array}$ & $\begin{array}{l}R-30 \\
R-19 \\
R-(3 \\
R-0 \\
R-0 \\
R-0 \\
\text { Obl W/O to } \\
\text { nOrmal } \\
\text { AFUE } 78 \% \\
\text { SEER } 10\end{array}$ & $\begin{array}{l}6.5 \\
2.0 \\
4.0 \\
0.0 \\
0.0 \\
0.0\end{array}$ & $\begin{array}{l}R-30 \\
R-23 \\
R-19 \\
R-19 \\
R-10 \_2 \mathrm{ft} \\
R-10-8 \mathrm{ft} \\
\text { ObI-ht_abs } \\
\text { nOrmal- } \\
\text { AFUE } 78 \% \\
\text { SEER } 10\end{array}$ & $\begin{array}{l}R-30 \\
R-23 \\
R-30 \\
R-30 \\
R-104 \mathrm{ft} \\
R-5=\overline{2} \mathrm{ft} \\
\text { ObL_LOH-E } \\
\text { nORmal } \\
\text { AFUE } 85 \% \\
\text { SEER } 10\end{array}$ & $\begin{array}{r}0.0 \\
0.0 \\
3.0 \\
3.0 \\
0.0 \\
-1.0\end{array}$ & $\begin{array}{l}R-19 \\
R-11 \\
R-11 \\
R+11 \\
R-5+4 \mathrm{ft} \\
R-0^{-} \\
\text {Db! th } \\
\text { nORTIL } \\
\text { AFUE } 78 \% \\
\text { SEER } 10\end{array}$ & $\begin{array}{l}R-30 \\
R-23 \\
R-30 \\
R-30 \\
R-10-4 \mathrm{ft} \\
R-5=\overline{2} \mathrm{ft} \\
\text { Db! LOW-E } \\
\text { nOrmal } \\
\text { AFUE } 95 \% \\
\text { SEER } 10\end{array}$ & $\begin{array}{l}6.5 \\
2.5 \\
5.5 \\
5.5 \\
1.0 \\
1.0\end{array}$ \\
\hline $\begin{array}{l}\text { Electric } \\
\text { forced } \\
\text { Air }\end{array}$ & $\begin{array}{l}\text { ceiling insulation } \\
\text { wall insulation } \\
\text { crawlspace insulation } \\
\text { base. floor insulation } \\
\text { base. Hall insulation } \\
\text { slab insulation } \\
\text { glazing type } \\
\text { infiltration } \\
\text { heating efficiency } \\
\text { cooling efficiency }\end{array}$ & $\begin{array}{l}R-19 \\
R-13 \\
R-13 \\
R-0 \\
R-0 \\
R-0 \\
\text { DbL_tb } \\
\text { normal } \\
\quad- \\
\text { SEER-10 }\end{array}$ & $\begin{array}{l}R-30 \\
R-23 \\
R-30 \\
R-30 \\
R-10 \_4 \mathrm{ft} \\
R-10 \_2 \mathrm{ft} \\
\text { Dot_Low-E } \\
\text { normal } \\
- \\
\text { SEER } 10\end{array}$ & $\begin{array}{l}6.5 \\
2.0 \\
8.0 \\
8.0 \\
1.0 \\
1.0\end{array}$ & $\begin{array}{l}R-38 \\
R-26 \\
R-19 \\
R-19 \\
R-10 \_8 \mathrm{ft} \\
R-10 \_2 \mathrm{ft} \\
\text { Tri_h_abs } \\
\text { normal } \\
- \\
\text { SEER } 10\end{array}$ & SEER - 10 & & $\begin{array}{l}R-19 \\
R-11 \\
R-11 \\
R-11 \\
R-5=4 \mathrm{ft} \\
R-0- \\
\text { Dbl_tb } \\
\text { normal } \\
\end{array}$ & & 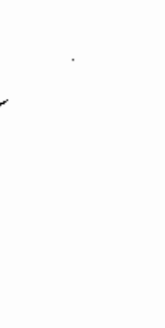 \\
\hline $\begin{array}{l}\text { Electric } \\
\text { Heat } \\
\text { Pump }\end{array}$ & $\begin{array}{l}\text { ceiling insulation } \\
\text { wall insulation } \\
\text { crawlspace insulation } \\
\text { base. floor insulation } \\
\text { base. Wall insulation } \\
\text { slab insulation } \\
\text { glazing type } \\
\text { infiltration } \\
\text { heating efficiency } \\
\text { Cooling efficiency }\end{array}$ & $\begin{array}{l}R=19 \\
R-13 \\
R-13 \\
R-0 \\
R-0 \\
R-0 \\
\text { Dbl_tb } \\
\text { normal } \\
\text { HSPF } 7.3 \\
\text { SEER } 10.0\end{array}$ & 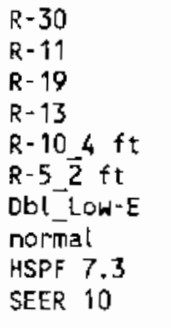 & $\begin{array}{r}6.5 \\
-0.5 \\
6.0 \\
4.0 \\
2.0 \\
1.0\end{array}$ & $\begin{array}{l}R-30 \\
R-23 \\
R-19 \\
R-19 \\
R-10 \_2 \mathrm{ft} \\
R=10-8 \mathrm{ft} \\
\text { Dbl-ht_abs } \\
\text { nOrmal } \\
\text { MSPF } 7.3 \\
\text { SEER } 10.0\end{array}$ & & & $\begin{array}{l}R-19 \\
R-11 \\
R-11 \\
R-11 \\
R-5 \text { ft ft } \\
R-0^{-} \\
\text {Db!_tb } \\
\text { normal } \\
\text { HSPF } 7.3 \\
\text { SEER } 10\end{array}$ & & \\
\hline oil & $\begin{array}{l}\text { ceiling insulation } \\
\text { wall insulation } \\
\text { crawlspace insulation } \\
\text { base. floor insulation } \\
\text { bose. Hall insulation } \\
\text { slab insulation } \\
\text { glazing type } \\
\text { infiltration } \\
\text { heating efficiency } \\
\text { cooling efficiency }\end{array}$ & & & & $\begin{array}{l}R-30 \\
R-23 \\
R-19 \\
R-19 \\
R-10-2 \mathrm{ft} \\
R-10-8 \mathrm{ft} \\
\text { Dbl-ht }-\mathrm{h} \text { abs } \\
\text { nornat } \\
\text { AFUE } 78 \% \\
\text { SEER } 10\end{array}$ & $\begin{array}{l}R-30 \\
R-23 \\
R-30 \\
R-30 \\
R-104 \mathrm{ft} \\
R-5=\overline{2} \mathrm{ft} \\
\text { DbL LOH-E } \\
\text { nOrmal } \\
\text { AFUE } 95 \% \\
\text { SEER } 10\end{array}$ & $\begin{array}{r}0.0 \\
0.0 \\
3.0 \\
3.0 \\
0.0 \\
-1.0\end{array}$ & $\begin{array}{l}R-19 \\
R-11 \\
R-11 \\
R+11 \\
R-54 \mathrm{ft} \\
R-0^{-} \\
\text {Dbl_tb } \\
\text { norma! } \\
\text { AFUE } 78 \% \\
\text { SEER } 10\end{array}$ & $\begin{array}{l}R-30 \\
R-23 \\
R-30 \\
R-13 \\
R-1044 \mathrm{ft} \\
R-5=2 \mathrm{ft} \\
\text { DbL_LOH-E } \\
\text { nOrmal } \\
\text { AFUE } 95 \% \\
\text { SEER } 10\end{array}$ & $\begin{array}{ll}6.5 & \\
2.5 & 1.0 \\
5.5 & \\
0.5 & \\
1.0 \\
1.0\end{array}$ \\
\hline
\end{tabular}

(a) Rhode Island has adopted a new, fuel-specific energy code that went into effect on October 1, 1988. Basel ine codes included in this study, however, reflect the code in place in March 1988, which was not fuel specific. 


\section{IABLE A.5 (Cont.)}

\begin{tabular}{|c|c|c|c|c|}
\hline & & $\begin{array}{l}\text { Base Line } \\
\text { Pasodena }\end{array}$ & $\begin{array}{c}\text { Ares } \\
\text { Pasadena } \\
\end{array}$ & $\begin{array}{l}\text { Change In } \\
\text { Insulation } \\
\text { (inches) } \\
\text { FG Sheath }\end{array}$ \\
\hline Gas & $\begin{array}{l}\text { ceiling insulation } \\
\text { wall insulation } \\
\text { crablspace insulation } \\
\text { base. floor insulation } \\
\text { basc. Wall insulation } \\
\text { slab insulation } \\
\text { glazing type } \\
\text { infiltration } \\
\text { heating efficiency } \\
\text { cooling efficicncy }\end{array}$ & $\begin{array}{l}R-19 \\
R-11 \\
R-19 \\
R-19 \\
R-0 \\
R-0 \\
S-w / 0-t b \\
\text { normal } \\
\text { AFUE- } 78 \% \\
\text { SEER- } 10\end{array}$ & $\begin{array}{l}R-30 \\
R-19 \\
R-11 \\
R=0 \\
R-0 \\
R-0 \\
\text { dbl_W/o tb } \\
\text { normal } \\
\text { AFUE } 78 \% \\
\text { SEER } 10\end{array}$ & $\begin{array}{r}6.5 \\
2.5 \\
-2.5 \\
-6.0 \\
0.0 \\
0.0\end{array}$ \\
\hline $\begin{array}{l}\text { Electric } \\
\text { Forced } \\
\text { Air }\end{array}$ & $\begin{array}{l}\text { ceiling insulation } \\
\text { wall insulation } \\
\text { crawl space insulation } \\
\text { base. floor insulation } \\
\text { base. wall insulation } \\
\text { slab insulation } \\
\text { glazing type } \\
\text { infiltration } \\
\text { hoating efficiency } \\
\text { cooling efficiency }\end{array}$ & $\begin{array}{l}R-19 \\
R-11 \\
R-19 \\
R-19 \\
R-0 \\
R-0 \\
S-w / O-t b \\
\text { normal } \\
\quad- \\
\text { SEER-10 }\end{array}$ & $\begin{array}{l}R-30 \\
R-23 \\
R=13 \\
R-11 \\
R-5 \quad 4 \mathrm{ft} \\
R-5=2 \mathrm{ft} \\
D b L_{-W} / 0 \mathrm{tb} \\
\text { normal } \\
\quad- \\
\text { SEER } 10\end{array}$ & $\begin{array}{rr}6.5 & \\
2.5 & 1.0 \\
-2.0 & \\
-2.5 & \\
1.0 & \\
1.0 & \end{array}$ \\
\hline $\begin{array}{l}\text { Electric } \\
\text { Heat } \\
\text { Purmo }\end{array}$ & $\begin{array}{l}\text { ceiling insulation } \\
\text { wal! insulation } \\
\text { crawlspace insulation } \\
\text { base. floor insulation } \\
\text { base. Wall insulation } \\
\text { slab insulation } \\
\text { glazing type } \\
\text { infiltration } \\
\text { heating efficiency } \\
\text { cooling efficiency }\end{array}$ & $\begin{array}{l}R-19 \\
R-11 \\
R-19 \\
R-19 \\
R-0 \\
R-0 \\
S-W / 0-\text { tb } \\
\text { normal } \\
\text { HSPF }-7.3 \\
\text { SEER } 10.0\end{array}$ & $\begin{array}{l}R-30 \\
R-19 \\
R-13 \\
R-0 \\
R-0 \\
R-0 \\
\text { Dbl w/O to } \\
\text { normal } \\
\text { HSPF } 7.3 \\
\text { SEER } 10\end{array}$ & $\begin{array}{r}6.5 \\
2.5 \\
-2.0 \\
-6.0 \\
0.0 \\
0.0\end{array}$ \\
\hline oil & $\begin{array}{l}\text { ceiling insulation } \\
\text { wall insulation } \\
\text { crawlspace insulation } \\
\text { base. floor insulation } \\
\text { base. Wall insulation } \\
\text { slab insulation } \\
\text { glazing type } \\
\text { infiltration } \\
\text { heating efficiency } \\
\text { cooling efficiency }\end{array}$ & NA & NA & $N A$ \\
\hline
\end{tabular}


TABLE A.6 Description of Prototype ECM's for the Multi-Family Residence

\begin{tabular}{|c|c|c|c|c|c|c|c|c|c|c|}
\hline & & $\begin{array}{c}\text { Base Line } \\
\text { Tampa } \\
\end{array}$ & $\begin{array}{l}\text { Ares } \\
\text { Tampa }\end{array}$ & $\begin{array}{l}\text { Change In } \\
\text { Insulation } \\
\text { (inches) } \\
\text { FG Sheath } \\
\end{array}$ & $\begin{array}{l}\text { 8ase Line } \\
\text { Phoenix }\end{array}$ & $\begin{array}{c}\text { Ares } \\
\text { Phoenix }\end{array}$ & $\begin{array}{l}\text { Change In } \\
\text { Insul at ion } \\
\text { (inches) } \\
\text { FG Sheath }\end{array}$ & $\begin{array}{l}\text { Base Line } \\
\text { At Lente }\end{array}$ & $\begin{array}{c}\text { Ares } \\
\text { Atlanta } \\
\end{array}$ & $\begin{array}{l}\text { Chenge In } \\
\text { Insulation } \\
\text { (inches) } \\
\text { FG Sheath }\end{array}$ \\
\hline Gas & $\begin{array}{l}\text { ceiling insulation } \\
\text { wall insulation } \\
\text { crawlspace insulation } \\
\text { base. floor insulation } \\
\text { base. wall insulation } \\
\text { slab insulation } \\
\text { glazing type } \\
\text { infiltration } \\
\text { heating efficiency } \\
\text { cooling efficiency }\end{array}$ & $\begin{array}{l}R-19 \\
R-19 \\
R-0 \\
R-0 \\
R-0 \\
R-10 \text { 2 ft } \\
\text { S_W/O IB } \\
\text { nOTHaL } \\
\text { AFUE } 78 \% \\
\text { SEER } 10\end{array}$ & $\begin{array}{l}R-19 \\
R-11 \\
R-0 \\
R-0 \\
R-0 \\
R-0 \\
\text { S_H_Abs } \\
\text { nOrmal } \\
\text { AFUE } 78 \% \\
\text { SEER } 10\end{array}$ & $\begin{array}{r}0.0 \\
-2.5 \\
0.0 \\
0.0 \\
0.0 \\
-2.0\end{array}$ & $\begin{array}{l}R-30 \\
R-13 \\
R-0 \\
R-0 \\
R-0 \\
R-0 \\
\text { S_W/O TB } \\
\text { nOrmal } \\
\text { AFUE } 78 \% \\
\text { SEER } 10\end{array}$ & $\begin{array}{l}R-19 \\
R-23 \\
R-13 \\
R-0 \\
R-5=4 \mathrm{ft} \\
R-0^{-} \\
\text {DbL_LOW-E } \\
\text { normal } \\
\text { AFUE } 78 \% \\
\text { SEER } 10\end{array}$ & $\begin{array}{rl}-6.5 & \\
2.0 & 1.0 \\
4.0 \\
0.0 \\
1.0 \\
0.0\end{array}$ & $\begin{array}{l}R-30 \\
R-13 \\
R-11 \\
R-0 \\
R-11 \\
R-0 \\
\text { Db! Th } \\
\text { norma! } \\
\text { AFUE } 95 \% \\
\text { SEER } 10\end{array}$ & $\begin{array}{l}R-30 \\
R-13 \\
R-11 \\
R-0 \\
R-5{ }^{-4} \mathrm{ft} \\
R-0^{-} \\
\text {Dbl } W / 0 \text { TB } \\
\text { nOrmal } \\
\text { AFUE } 80 \% \\
\text { SEER } 10\end{array}$ & $\begin{array}{r}0.0 \\
0.0 \\
0.0 \\
-3.5 \\
1.0 \\
0.0\end{array}$ \\
\hline $\begin{array}{l}\text { Electric } \\
\text { Forecd } \\
\text { Air }\end{array}$ & $\begin{array}{l}\text { cciting insulation } \\
\text { wall insulation } \\
\text { crawlspace insulation } \\
\text { base. floor insulation } \\
\text { base. Wall insulation } \\
\text { slab insulation } \\
\text { glazing type } \\
\text { infiltration } \\
\text { heating efficiency } \\
\text { cooling efficiency }\end{array}$ & $\begin{array}{l}R-19 \\
R-19 \\
R-0 \\
R-0 \\
R-0 \\
R-102 \mathrm{ft} \\
\text { S_W/O TB } \\
\text { normal } \\
\quad- \\
\text { SEER } 10\end{array}$ & $\begin{array}{l}R-19 \\
R-11 \\
R-11 \\
R-0 \\
R=0 \\
R-0 \\
\text { DbL W/o TB } \\
\text { nornal } \\
-\quad \\
\text { SEER } 10\end{array}$ & $\begin{array}{r}0.0 \\
-2.5 \\
3.5 \\
0.0 \\
0.0 \\
-2.0\end{array}$ & $\begin{array}{l}R-30 \\
R-13 \\
R-0 \\
R-0 \\
R-0 \\
R-0 \\
\text { S_H/O TB } \\
\text { norma! } \\
\quad- \\
\text { SEER } 10\end{array}$ & $\begin{array}{l}R-30 \\
R-23 \\
R-30 \\
R-11 \\
R-10+4 \mathrm{ft} \\
R-0 \\
D b L_{-} T B \\
\text { normal } \\
- \\
\text { SEER } 10\end{array}$ & $\begin{array}{l}0.0 \\
2.0 \\
9.0 \\
3.5 \\
2.0 \\
0.0\end{array}$ & $\begin{array}{l}R-30 \\
R-13 \\
R-11 \\
R-0 \\
R-11 \\
R-0 \\
\text { Dbl TB } \\
\text { norma! } \\
\quad- \\
\text { SEER } 10\end{array}$ & $\begin{array}{l}R-30 \\
R-23 \\
R-30 \\
R-11 \\
R-10-4 \mathrm{ft} \\
R-5-\overline{2} \mathrm{ft} \\
\text { Dbl } W / 0 \text { TB } \\
\text { normal } \\
- \\
\text { SEER } 10\end{array}$ & $\begin{array}{l}0.0 \\
2.01 .0 \\
5.5 \\
0.0 \\
2.0 \\
1.0\end{array}$ \\
\hline $\begin{array}{l}\text { Electric } \\
\text { Heat } \\
\text { Pump }\end{array}$ & $\begin{array}{l}\text { ceiling insulation } \\
\text { wall insulation } \\
\text { crawlspece insulation } \\
\text { base. floor insulation } \\
\text { base. Hall insulation } \\
\text { slab insulation } \\
\text { glazing type } \\
\text { infiltration } \\
\text { heating cfficiency } \\
\text { cooling efficiency }\end{array}$ & $\begin{array}{l}R-19 \\
R-19 \\
R-0 \\
R-0 \\
R-0 \\
R-102 \text { FT } \\
S \text { W TB } \\
\text { normal } \\
\text { HSPF } ?, 3 \\
\text { SEER } 10\end{array}$ & $\begin{array}{l}R-30 \\
R-11 \\
R-0 \\
R-0 \\
R-0 \\
R-0 \\
\text { Db! W/O TB } \\
\text { nOrmaL } \\
\text { HSPF } 7.3 \\
\text { SEER } 10\end{array}$ & $\begin{array}{r}6.5 \\
-2.5 \\
0.0 \\
0.0 \\
0.0 \\
-2.0\end{array}$ & $\begin{array}{l}R-30 \\
R-13 \\
R-0 \\
R-0 \\
R-0 \\
R-0 \\
\text { S_H/O TB } \\
\text { nOrMal } \\
\text { HSPF } 7.3 \\
\text { SEER } 10\end{array}$ & $\begin{array}{l}R-30 \\
R-19 \\
R-11 \\
R-0 \\
R-5=4 F T \\
R-0^{-} \\
\text {Obl_LOH-E } \\
\text { normal } \\
\text { HSPF } 7.3 \\
\text { SEER } 10\end{array}$ & $\begin{array}{l}0.0 \\
2.0 \\
3.5 \\
0.0 \\
1.0 \\
0.0\end{array}$ & $\begin{array}{l}R-30 \\
R-13 \\
R-11 \\
R-0 \\
R-11 \\
R-0 \\
\text { Dbl TB } \\
\text { normel } \\
\text { HSPF } 7.3 \\
\text { SEER } 10\end{array}$ & $\begin{array}{l}R-30 \\
R-13 \\
R-11 \\
R-0 \\
R-5 \quad 4 \text { FT } \\
R-0^{-} \\
\text {D HL H/O TB } \\
\text { nOFma L } \\
\text { HSPF } 7.3 \\
\text { SEER } 10\end{array}$ & $\begin{array}{r}0 . \\
0.0 \\
0.0 \\
-3.5 \\
1.0 \\
0.0\end{array}$ \\
\hline oil & $\begin{array}{l}\text { house type } \\
\text { heat eq. type } \\
\text { ceiling insutation } \\
\text { wall insulation } \\
\text { crawlspace insulation } \\
\text { base. floor insulation } \\
\text { base. wall insulation } \\
\text { slab insulation } \\
\text { glazing typc } \\
\text { infiltration } \\
\text { heating efficiency } \\
\text { cooling efficiency }\end{array}$ & $N A$ & NA & & NA & $\mathrm{NA}$ & & $\mathrm{NA}$ & NA & \\
\hline
\end{tabular}


IABLE A.6 (Cont.)

\begin{tabular}{|c|c|c|c|c|c|c|c|c|c|c|}
\hline & & $\begin{array}{l}\text { Base line } \\
\text { Seattle. }\end{array}$ & $\begin{array}{c}\text { Ares } \\
\text { Seattle } \\
\end{array}$ & $\begin{array}{l}\text { Change In } \\
\text { Insulation } \\
\text { (inches) } \\
\text { FG Sheath } \\
\end{array}$ & $\begin{array}{l}\text { Base Line } \\
\text { Denver }\end{array}$ & $\begin{array}{c}\text { Ares } \\
\text { Denver }\end{array}$ & $\begin{array}{l}\text { Change In } \\
\text { Insulation } \\
\text { (inches) } \\
\text { FG Sheath } \\
\end{array}$ & $\begin{array}{l}\text { Base Line } \\
\text { Minneapo! }\end{array}$ & $\begin{array}{c}\text { Ares } \\
\text { Minneapol }\end{array}$ & $\begin{array}{c}\text { Change in } \\
\text { Insulation } \\
\text { (inches) } \\
\text { FG Sheath } \\
\end{array}$ \\
\hline Gas & $\begin{array}{l}\text { ceiling insulation } \\
\text { wall insulation } \\
\text { crawlspace insulation } \\
\text { base. floor insulation } \\
\text { base. wall insulatoin } \\
\text { slab insulation } \\
\text { glazing type } \\
\text { infiltration } \\
\text { heating efficiency } \\
\text { cooling efficiency }\end{array}$ & $\begin{array}{l}R-38 \\
R-19 \\
R-19 \\
R-19 \\
R-5=4 \mathrm{ft} \\
R-5=2 \mathrm{ft} \\
\text { Dbt_LOW-E } \\
\text { normal } \\
\text { AFUE } 78 \% \\
\text { SEER } 10\end{array}$ & $\begin{array}{l}R-30 \\
R-23 \\
R-30 \\
R-11 \\
R-5-4 \mathrm{ft} \\
R-5-2 \mathrm{ft} \\
\text { Dbl } \mathrm{H} / \mathrm{O} \text { TB } \\
\text { nOFmal } \\
\text { AFUE } 78 \% \\
\text { SEER } 10\end{array}$ & $\begin{array}{rl}-3.5 & \\
0.0 & 1.0 \\
3.0 \\
-2.5 \\
0.0 \\
0.0\end{array}$ & $\begin{array}{l}R-30 \\
R=13 \\
R-13 \\
R=0 \\
R=0 \\
R-0 \\
\text { DDI TB } \\
\text { nOrmal } \\
\text { AFUE } 80 \% \\
\text { SEER } 10\end{array}$ & $\begin{array}{l}R-30 \\
R-23 \\
R-13 \\
R-11 \\
R-5-4 \mathrm{ft} \\
R-5-2 \mathrm{ft} \\
\text { DDL W/O TB } \\
\text { nOrת! } \\
\text { AFUE } 78 \% \\
\text { SEER } 10\end{array}$ & $\begin{array}{l}0.0 \\
2.0 \\
0.0 \\
3.5 \\
1.0 \\
1.0\end{array}$ & $\begin{array}{l}R-38 \\
R-19 \\
R-19 \\
R-19 \\
R-104 \mathrm{ft} \\
R-5-\frac{\mathrm{ft}}{\mathrm{ft}} \\
\text { Dbl TB } \\
\text { nORMal } \\
\text { AFUE } 78 \% \\
\text { SEER } 10\end{array}$ & $\begin{array}{l}R-30 \\
R-23 \\
R-30 \\
R-11 \\
R-5-4 \mathrm{ft} \\
R-5-2 \mathrm{ft} \\
\text { DbI LOH-E } \\
\text { nORMOL } \\
\text { AFUE } 78 \% \\
\text { SEER } 10\end{array}$ & $\begin{array}{rl}-3.5 & \\
0.0 & 1.0 \\
3.0 & \\
-2.5 & \\
-1.0 & \\
0.0 & \end{array}$ \\
\hline $\begin{array}{l}\text { Electric } \\
\text { Forced } \\
\text { Air }\end{array}$ & $\begin{array}{l}\text { ceiling insulation } \\
\text { wall insulation } \\
\text { crawlspace insulation } \\
\text { base. floor insulation } \\
\text { base. wall insulation } \\
\text { slab insulation } \\
\text { glazing type } \\
\text { infiltration } \\
\text { heating efficiencies } \\
\text { cooling efficiency }\end{array}$ & $\begin{array}{l}R-38 \\
R-19 \\
R-19 \\
R-19 \\
R-5=4 \mathrm{ft} \\
R-5-2 \mathrm{ft} \\
\text { DbL-LOW-E } \\
\text { normal } \\
\quad- \\
\text { SEER } 10\end{array}$ & $\begin{array}{l}R-30 \\
R-23 \\
R \cdot 30 \\
R-30 \\
R-10-4 \mathrm{ft} \\
R-10=2 \mathrm{ft} \\
D b L=T B \\
\text { normal } \\
- \\
\text { SEER } 10\end{array}$ & $\begin{aligned}-3.5 \\
0.01 \\
3.0 \\
3.0 \\
1.0 \\
1.0\end{aligned}$ & $\begin{array}{l}R-30 \\
R-13 \\
R-13 \\
R-0 \\
R-0 \\
R-0 \\
\text { DDL TB } \\
\text { nOFMRI } \\
\quad- \\
\text { SEER } 10\end{array}$ & $\begin{array}{l}R-30 \\
R-23 \\
R-30 \\
R-30 \\
R-10 \_4 \mathrm{ft} \\
R-10=2 \mathrm{ft} \\
\text { Obl_TB } \\
\text { normal } \\
\quad- \\
\text { SEER } 10\end{array}$ & $\begin{array}{l}0.0 \\
2.0 \\
5.0 \\
9.0 \\
2.0 \\
2.0\end{array}$ & $\begin{array}{l}R-38 \\
R-19 \\
R-19 \\
R-19 \\
R-1044 \mathrm{ft} \\
R-5-4 \mathrm{ft} \\
\text { Dbl TB } \\
\text { nOrmal } \\
\text { - } \\
\text { SEER } 10\end{array}$ & $\begin{array}{l}R-30 \\
R-26 \\
R-30 \\
R-11 \\
R-10 \_8 \mathrm{ft} \\
R-10 \_4 \mathrm{ft} \\
\text { Dbl_Lot-E } \\
\text { normal } \\
- \\
\text { SEER } 10\end{array}$ & $\begin{array}{rl}-3.5 & \\
0.0 & 2.0 \\
3.0 & \\
-2.5 & \\
0.0 & \\
1.0 & \end{array}$ \\
\hline $\begin{array}{l}\text { Electric } \\
\text { Heat } \\
\text { Pump }\end{array}$ & $\begin{array}{l}\text { ceiling insulation } \\
\text { wall insulation } \\
\text { crawlspace insulation } \\
\text { base. floor insulation } \\
\text { base. wall insulation } \\
\text { slab insulation } \\
\text { glazing type } \\
\text { infiltration } \\
\text { heating efficiency } \\
\text { cooling efficiency }\end{array}$ & $\begin{array}{l}R-38 \\
R-19 \\
R-19 \\
R-19 \\
R-5=4 \mathrm{ft} \\
R-5=2 \mathrm{ft} \\
\text { DbL_LOW-E } \\
\text { normal } \\
\text { HSPF } 7.3 \\
\text { SEER } 10\end{array}$ & $\begin{array}{l}R-30 \\
R-23 \\
R-11 \\
R-11 \\
R-5-4 \mathrm{ft} \\
R-5-2 \mathrm{ft} \\
\text { Dbl }-\mathrm{W} / \mathrm{T} \mathrm{TB} \\
\text { MOrmal } \\
\text { HSPF } 7.3 \\
\text { SEER } 10\end{array}$ & $\begin{array}{r}-3.5 \\
0.01 .0 \\
-2.5 \\
-2.5 \\
0.0 \\
0.0\end{array}$ & $\begin{array}{l}R-30 \\
R-13 \\
R-13 \\
R=0 \\
R-0 \\
R-0 \\
\text { DbL TB } \\
\text { normal } \\
\text { HSPF } 7.3 \\
\text { SEER } 10\end{array}$ & $\begin{array}{l}R-30 \\
R-23 \\
R-30 \\
R-11 \\
R-5-4 \mathrm{ft} \\
R-5-2 \mathrm{ft} \\
\text { Dbi } \mathrm{W} / \mathrm{O} \text { TB } \\
\text { nOrma! } \\
\text { HSPF } 7.3 \\
\text { SEER } 10\end{array}$ & $\begin{array}{ll}0.0 & \\
2.0 & 1.0 \\
5.0 & \\
3.5 & \\
1.0 & \\
1.0 & \end{array}$ & $\begin{array}{l}R-38 \\
R-19 \\
R-19 \\
R-19 \\
R-10-4 \mathrm{ft} \\
R-5=\frac{\mathrm{ft}}{} \\
\text { DbL TB } \\
\text { normal } \\
\text { HSPF } 7.3 \\
\text { SEER } 10\end{array}$ & $\begin{array}{l}R-30 \\
R-26 \\
R-30 \\
R-11 \\
R-10+4 \mathrm{ft} \\
R-10-2 \mathrm{ft} \\
\text { DbL_Low-E } \\
\text { normal } \\
\text { HSPF } 7.3 \\
\text { SEER } 10\end{array}$ & $\begin{array}{r}-3.5 \\
0.02 .0 \\
3.0 \\
-2.5 \\
0.0 \\
1.0\end{array}$ \\
\hline oil & $\begin{array}{l}\text { ceiling insulation } \\
\text { wall insulation } \\
\text { crawispace insulation } \\
\text { base. floor insulation } \\
\text { base. wall insulation } \\
\text { slab insulation } \\
\text { glazing type } \\
\text { irfiltration } \\
\text { heating efficiency } \\
\text { cooling efficiency }\end{array}$ & NA & NA & & NA & NA & & NA & NA & \\
\hline
\end{tabular}


IABLE A.6 (Cont.)

\begin{tabular}{|c|c|c|c|c|c|c|c|c|c|c|}
\hline & & $\begin{array}{l}\text { Base Line } \\
\text { Ft Worth }\end{array}$ & $\begin{array}{c}\text { Ares } \\
\text { Ft Worth } \\
\end{array}$ & $\begin{array}{l}\text { Change In } \\
\text { Insulation } \\
\text { (inches) } \\
\text { fG Sheath. }\end{array}$ & $\begin{array}{l}\text { Base Line } \\
\text { Albany }\end{array}$ & $\begin{array}{c}\text { Ares } \\
\text { Albany }\end{array}$ & $\begin{array}{l}\text { Change In } \\
\text { Insulation } \\
\text { (inches) } \\
\text { FG Sheath }\end{array}$ & $\begin{array}{l}\text { Base Line } \\
\text { Providence }\end{array}$ & $\begin{array}{c}\text { Ares } \\
\text { Providence (a) }\end{array}$ & $\begin{array}{l}\text { Change In } \\
\text { Insulation } \\
\text { (inches) } \\
\text { FG Sheath }\end{array}$ \\
\hline Gas & $\begin{array}{l}\text { ceiling insulation } \\
\text { wall insulation } \\
\text { crawlspace insulation } \\
\text { base. floor insulation } \\
\text { base. wall insulation } \\
\text { slab insulation } \\
\text { glazing type } \\
\text { infiltration } \\
\text { heating efficiency } \\
\text { cooling efficiency }\end{array}$ & $\begin{array}{l}R-19 \\
R-13 \\
R-0 \\
R-0 \\
R-0 \\
R-0 \\
\text { Dbl TB } \\
\text { normal } \\
\text { AFUE } 78 \% \\
\text { SEER } 10\end{array}$ & $\begin{array}{l}R-30 \\
R-19 \\
R-13 \\
R-0 \\
R-5-4 \mathrm{ft} \\
R-0 \\
\text { DDI H/O TB } \\
\text { nOImal } \\
\text { AFUE } 78 \% \\
\text { SEER } 10\end{array}$ & $\begin{array}{l}6.5 \\
2.0 \\
4.0 \\
0.0 \\
1.0 \\
0.0\end{array}$ & $\begin{array}{l}R-38 \\
R-26 \\
R-19 \\
R-19 \\
R-10-4 \mathrm{ft} \\
R-10-2 \mathrm{ft} \\
T r i=-B \\
\text { normal } \\
\text { AFUE } 78 \% \\
\text { SEER } 10\end{array}$ & $\begin{array}{l}R-30 \\
R-23 \\
R-30 \\
R-13 \\
R-5-4 \mathrm{ft} \\
R-5=2 \mathrm{ft} \\
\text { DbL W/o TB } \\
\text { nORMal } \\
\text { AFUE 78\% } \\
\text { SEER } 10\end{array}$ & $\begin{array}{l}-3.5 \\
0.0-1.0 \\
3.0 \\
-2.0 \\
-1.0 \\
-1.0\end{array}$ & $\begin{array}{l}R-19 \\
R-11 \\
R-11 \\
R-11 \\
R-0 \\
R-0 \\
\text { DbL TB } \\
\text { nOrmaL } \\
\text { AFUE } 78 \% \\
\text { SEER } 10\end{array}$ & $\begin{array}{l}R-30 \\
R-23 \\
R-30 \\
R-13 \\
R-5-4 \mathrm{ft} \\
R-5=2 \mathrm{ft} \\
\text { DEL_LOW-E } \\
\text { nOrMal } \\
\text { AFUE } 78 \% \\
\text { SEER } 10\end{array}$ & $\begin{array}{l}6.5 \\
2.5 \\
5.5 \\
0.5 \\
1.0 \\
1.0\end{array}$ \\
\hline $\begin{array}{l}\text { Electric } \\
\text { Forced } \\
\text { air }\end{array}$ & $\begin{array}{l}\text { ceiling insulation } \\
\text { wall insulation } \\
\text { crawlspace insulation } \\
\text { base. floor insulation } \\
\text { base. wall insulation } \\
\text { shab insulation } \\
\text { glazing type } \\
\text { infiltration } \\
\text { heating efficiency } \\
\text { cooling efficiency }\end{array}$ & $\begin{array}{l}R-19 \\
R-13 \\
R-0 \\
R-0 \\
R-0 \\
R-0 \\
D b C \text { TB } \\
\text { normal } \\
\quad- \\
\text { SEER } 10\end{array}$ & $\begin{array}{l}R-30 \\
R-23 \\
R-30 \\
R-13 \\
R-10-4 \mathrm{ft} \\
R-5-2 \mathrm{ft} \\
\text { Dbl }-\mathrm{H} / 0 \mathrm{~TB} \\
\text { nOImal } \\
\text { SEER } 10\end{array}$ & $\begin{array}{l}6.5 \\
2.01 .0 \\
9.0 \\
4.0 \\
2.0 \\
1.0\end{array}$ & $\begin{array}{l}R-38 \\
R-26 \\
R-19 \\
R-19 \\
R-10-4 \mathrm{ft} \\
R-10-2 \mathrm{ft} \\
T r i=-78 \\
\text { normel } \\
- \\
\text { SEER } 10\end{array}$ & $\begin{array}{l}R-49 \\
R-26 \\
R-30 \\
R-30 \\
R-10 \_4 \mathrm{ft} \\
R-10-4 \mathrm{ft} \\
\text { DG__ow E } \\
\text { normal } \\
\text { - } \\
\text { SEER } 10\end{array}$ & & $\begin{array}{l}R-19 \\
R+11 \\
R-11 \\
R-11 \\
R-0 \\
R-0 \\
\text { DbL TB } \\
\text { normal } \\
- \\
\text { SEER } 10\end{array}$ & $\begin{array}{l}R-60 \\
R-26 \\
R-30 \\
R-30 \\
R-10 \_8 \mathrm{ft} \\
R+10-4 \mathrm{ft} \\
\text { Db!_Low E } \\
\text { normai } \\
- \\
\text { SEER } 10\end{array}$ & \\
\hline $\begin{array}{l}\text { Electric } \\
\text { Heat } \\
\text { Punmp }\end{array}$ & $\begin{array}{l}\text { ceiling insulation } \\
\text { wall insulation } \\
\text { crawlspace insulation } \\
\text { base. floor insulation } \\
\text { base. Wall insulation } \\
\text { slab insulation } \\
\text { glazing type } \\
\text { infiltration } \\
\text { heating efficiency } \\
\text { cooling efficiency }\end{array}$ & $\begin{array}{l}R-19 \\
R-13 \\
R-0 \\
R-0 \\
R=0 \\
R-0 \\
\text { ObL TB } \\
\text { nORma! } \\
\text { HSPF } 7.3 \\
\text { SEER } 10\end{array}$ & $\begin{array}{l}R-30 \\
R-13 \\
R-13 \\
R-0 \\
R-5 L^{-4 t} \\
R-0^{-} \\
\text {ObL_LOH-E } \\
\text { nORma! } \\
\text { HSPF } 7.3 \\
\text { SEER } 10\end{array}$ & $\begin{array}{l}6.5 \\
0.0 \\
4.0 \\
0.0 \\
1.0 \\
0.0\end{array}$ & $\begin{array}{l}R-38 \\
R-26 \\
R-19 \\
R-19 \\
R-10=4 \mathrm{ft} \\
R-10=2 \mathrm{ft} \\
T r i=-9 \\
\text { nOFmal } \\
\text { HSPF } 7.3 \\
\text { SEER } 10\end{array}$ & $\begin{array}{l}R-30 \\
R-23 \\
R-30 \\
R-30 \\
R-10-4 \mathrm{ft} \\
R-10-2 \mathrm{ft} \\
\text { Ob! LoN-E } \\
\text { nORTal } \\
\text { HSPF } 7.3 \\
\text { SEER } 10\end{array}$ & & $\begin{array}{l}R-19 \\
R-11 \\
R-11 \\
R-11 \\
R-0 \\
R-0 \\
\text { DbL TB } \\
\text { normal } \\
\text { HSPF } 7.3 \\
\text { SEER } 10\end{array}$ & $\begin{array}{l}R-38 \\
R-23 \\
R-30 \\
R-30 \\
R-104 \mathrm{ft} \\
R-10-2 \mathrm{ft} \\
\text { DDI LOH-E } \\
\text { normal } \\
\text { HSPF } 7.3 \\
\text { SEER } 10\end{array}$ & \\
\hline oil & $\begin{array}{l}\text { ceiling insulation } \\
\text { wall insulation } \\
\text { crawlspace insulation } \\
\text { base. floor insulation } \\
\text { bese. Kall insulation } \\
\text { slab insulation } \\
\text { glazing type } \\
\text { infiltration } \\
\text { heating efficiency } \\
\text { cooling efficiency }\end{array}$ & NA & NA & & $\begin{array}{l}R-38 \\
R-26 \\
R-19 \\
R-19 \\
R-10-4 \mathrm{ft} \\
R-10^{-} 2 \mathrm{ft} \\
T \mathrm{Ti} T \mathrm{~T} \\
\text { normal } \\
\text { AFUE } 78 \% \\
\text { SEER } 10\end{array}$ & $\begin{array}{l}R-30 \\
R-23 \\
R-30 \\
R-30 \\
R-10<4 \mathrm{ft} \\
R-10=2 \mathrm{ft} \\
\text { DOL LOH-E } \\
\text { nOFma! } \\
\text { AFUE } 80 \% \\
\text { SEER } 10\end{array}$ & $\begin{array}{l}-3.5 \\
0.0-1.0 \\
3.0 \\
3.0 \\
0.0 \\
0.0\end{array}$ & $\begin{array}{l}R-19 \\
R-11 \\
R-11 \\
R-11 \\
R-0 \\
R-0 \\
\text { DbI TB } \\
\text { normal } \\
\text { AFUE } 78 \% \\
\text { SEER } 10\end{array}$ & $\begin{array}{l}R-30 \\
R-23 \\
R-30 \\
R-13 \\
R-10 \_4 \mathrm{ft} \\
R-10 \_2 \mathrm{ft} \\
\text { ObL_Low-E } \\
\text { nOrmal } \\
\text { AFUE } 78 \% \\
\text { SEER } 10\end{array}$ & $\begin{array}{l}6.5 \\
2.59 .0 \\
5.5 \\
0.5 \\
2.0 \\
2.0\end{array}$ \\
\hline
\end{tabular}

(a) Rhode Island has adopted a new, fuel-specific energy code that went into effect on october 1, 1988. Basel ine codes included in this study, however, reflect the code in place in March 1988, which was not fuel specific. 


\section{TABLE A.6 (Cont.)}

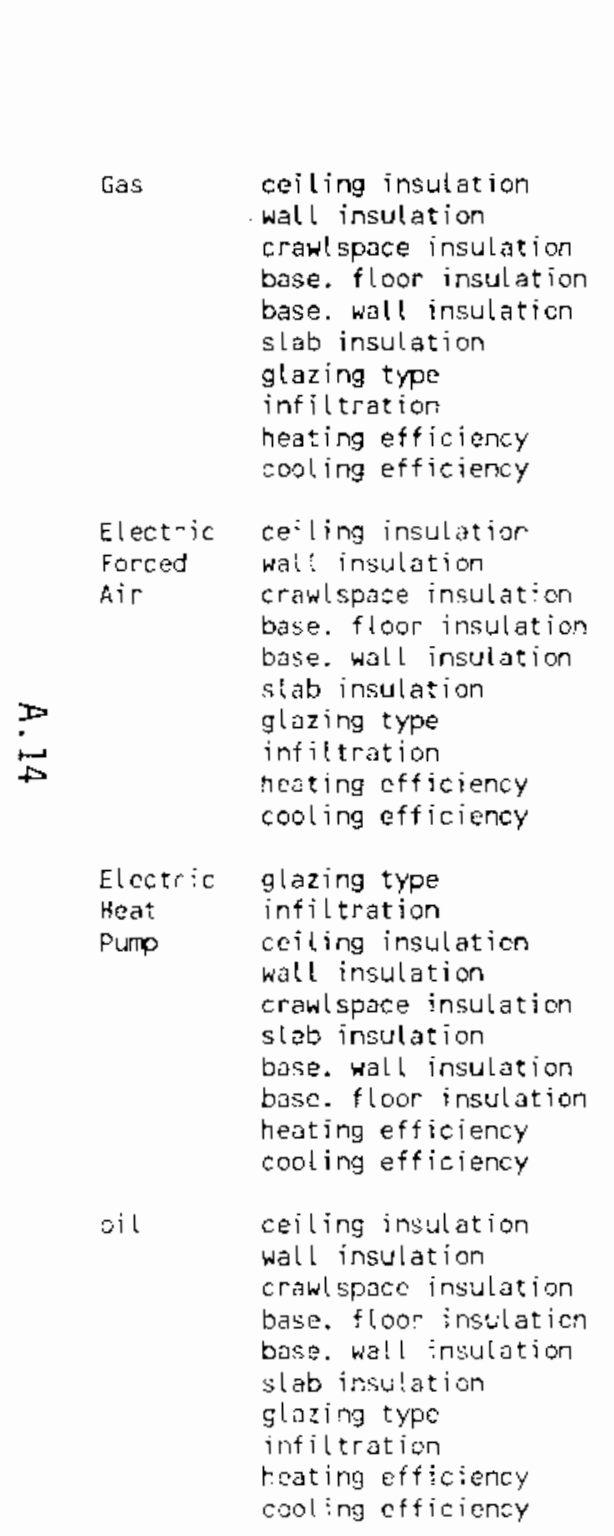

$\begin{array}{lcc}\text { Base Line } & \text { Ares } & \begin{array}{c}\text { Change in } \\ \text { Insulation } \\ \text { (inches) }\end{array} \\ \text { Pasadena_ } \quad \text { Pasadena } & \text { FG Sheath }\end{array}$

$\begin{array}{lll}R-30 & R-30 & 0.0\end{array}$

$\begin{array}{lll}R-11 & R-13 & 0.5 \\ R-19 & R-11 & -2.5\end{array}$

$\begin{array}{lll}R-19 & R-11 & -2.5 \\ R-19 & -6.0\end{array}$

$\begin{array}{llr}R-19 & R-0 & -6.0 \\ R-0 & R-0 & 0.0\end{array}$

$\begin{array}{lll}R-0 & R-0 & 0.0\end{array}$

5 W/O TB Sgl W/O TB

norma! normal

nOFIM - 78\% AFUE $78 \%$

SEER - 10 SEER 10

$\begin{array}{llr}R-30 & R-30 & 0.0 \\ R-11 & R-19 & 2.5 \\ R-19 & R-13 & -2.0 \\ R-19 & R-0 & -6.0 \\ R-0 & R-5{ }^{-4} \mathrm{ft} & 1.0 \\ R-0 & R-0- & 0.0 \\ \text { S W/O TB } & \text { Obl W/O TB } \\ \text { nOImal } & \text { nOrmal } \\ - & - & \\ \text { SEER-10 } & \text { SEER } 10 & \end{array}$

$\begin{array}{llr}\text { S w/o TB } & \text { Dbl w/o TB } \\ \text { normal } & \text { normal } & \\ R-30 & R-30 & 0.0 \\ R-11 & R-13 & 0.5 \\ R-19 & R-11 & -2.5 \\ R-0 & R-0 & 0.0 \\ R-0 & \text { R-0 } & 0.0 \\ R-19 & \text { R-O } & -6.0 \\ \text { HSPF }-7.3 & \text { HSPF } 7.3 & \\ \text { SEER } 10.0 & \text { SEER } 10 & \end{array}$

SEER 10.0 SEER 10

NA

NA 
TABLE A.7 Description of Prototype ECM's for the Manufactured Homes

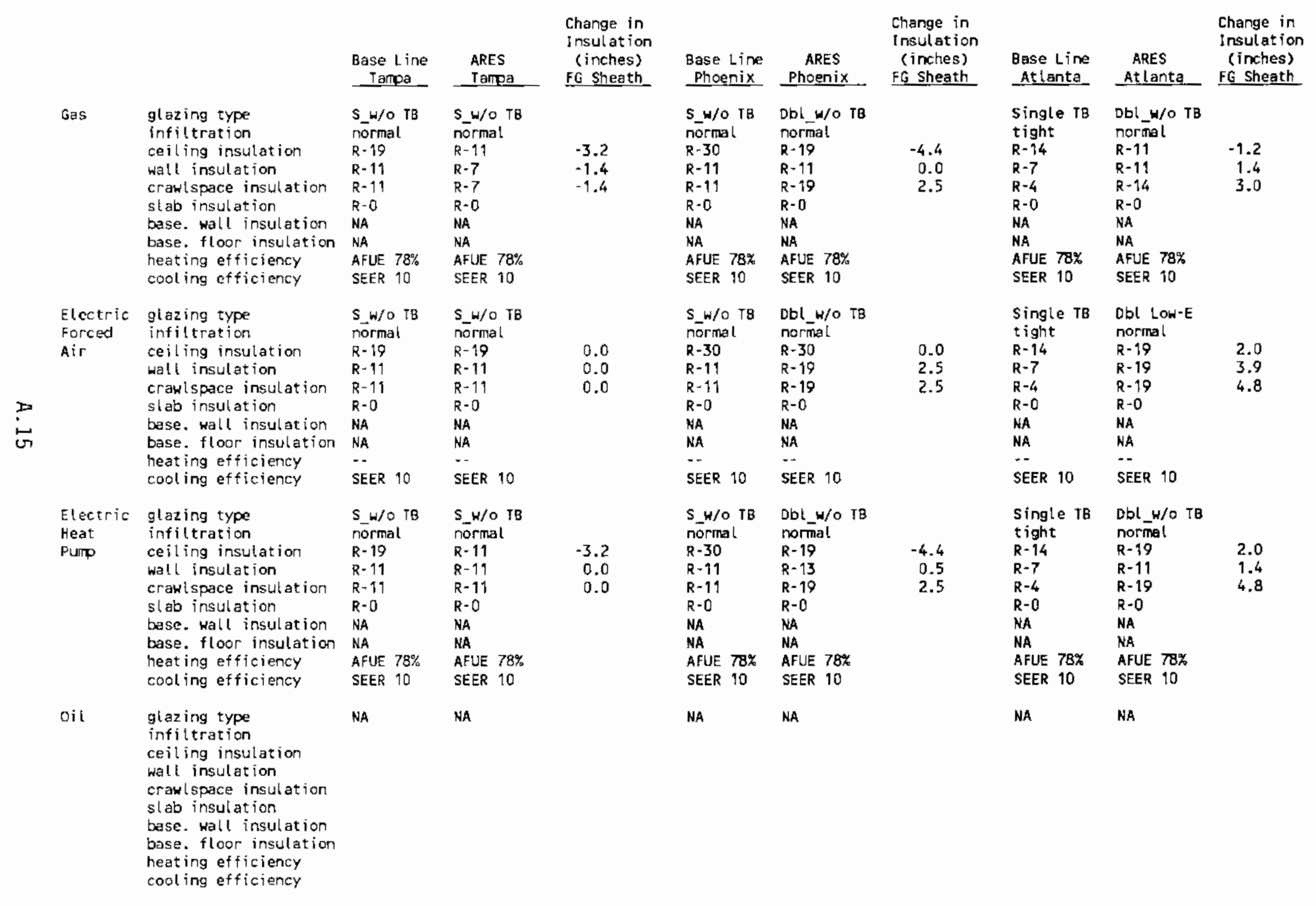


TABLE A.7 (contd)

\begin{tabular}{|c|c|c|c|c|c|c|c|c|c|c|}
\hline & & $\begin{array}{l}\text { Base Line } \\
\text { Seattle } \\
\end{array}$ & $\begin{array}{c}\text { ARES } \\
\text { Seattle } \\
\end{array}$ & $\begin{array}{l}\text { Change in } \\
\text { Insulation } \\
\text { (inches) } \\
\text { FG Sheath }\end{array}$ & $\begin{array}{l}\text { Base Line } \\
\text { Denver }\end{array}$ & $\begin{array}{l}\text { ARES } \\
\text { Denver }\end{array}$ & $\begin{array}{l}\text { Change in } \\
\text { insulation } \\
\text { (inches) } \\
\text { FG Sheath }\end{array}$ & $\begin{array}{l}\text { Base Line } \\
\text { Minneapol is }\end{array}$ & $\begin{array}{c}\text { ARES } \\
\text { At lanta } \\
\end{array}$ & $\begin{array}{l}\text { Change in } \\
\text { Insulation } \\
\text { (inches) } \\
\text { FG Sheath }\end{array}$ \\
\hline Gas & $\begin{array}{l}\text { glazing type } \\
\text { infiltration } \\
\text { ceiling insulation } \\
\text { walt insulation } \\
\text { crawlspace insulation } \\
\text { slab insulation } \\
\text { base. wall insulation } \\
\text { base. floor insulation } \\
\text { heating officiency } \\
\text { cooling efficiency }\end{array}$ & $\begin{array}{l}\text { Dbl_W/O TB } \\
\text { nOrnal } \\
R-19 \\
R-11 \\
R-11 \\
R-0 \\
\text { NA } \\
\text { NA } \\
\text { AFUE } 78 \% \\
\text { SEER } 10\end{array}$ & $\begin{array}{l}\text { Dbl_H/O TB } \\
\text { normal } \\
R-19 \\
R=11 \\
R-19 \\
R-0 \\
\text { NA } \\
\text { NA } \\
\text { AFUE } 78 \% \\
\text { SEER } 10\end{array}$ & $\begin{array}{l}0.0 \\
0.0 \\
2.5\end{array}$ & $\begin{array}{l}\text { S_W/O TB } \\
\text { normal } \\
R-19 \\
R-19 \\
R-11 \\
R-0 \\
\text { NA } \\
\text { NA } \\
\text { AFUE } 78 \% \\
\text { SEER } 10\end{array}$ & $\begin{array}{l}\text { Dbl_W/o TB } \\
\text { nOrmal } \\
R-19 \\
R-11 \\
R-19 \\
R-0 \\
\text { NA } \\
\text { NA } \\
\text { AFUE } 78 \% \\
\text { SEER } 10\end{array}$ & $\begin{array}{r}0.0 \\
-2.5 \\
2.5\end{array}$ & $\begin{array}{l}\text { Dbl TB } \\
\text { normal } \\
R-3 D \\
R-19 \\
R-11 \\
R-0 \\
\text { NA } \\
\text { NA } \\
\text { AFUE } 78 \% \\
\text { SEER } 10\end{array}$ & $\begin{array}{l}\text { Dbl Low-E } \\
\text { nornal } \\
R-19 \\
R-11 \\
R-19 \\
R-0 \\
\text { NA } \\
\text { NA } \\
\text { AFUE } 78 \% \\
\text { SEER } 10\end{array}$ & $\begin{array}{r}-4.4 \\
-2.5 \\
2.5\end{array}$ \\
\hline $\begin{array}{l}\text { Electric } \\
\text { Forced } \\
\text { Air }\end{array}$ & $\begin{array}{l}\text { glazing type } \\
\text { infiltration } \\
\text { ceiling insulation } \\
\text { Hall insulation } \\
\text { crawlspece insulation } \\
\text { slab insulation } \\
\text { base. Wall insulation } \\
\text { base. floor insulation } \\
\text { heating efficiency } \\
\text { cooling efficiency }\end{array}$ & $\begin{array}{l}\text { DbL_H/O TB } \\
\text { normal } \\
R-19 \\
R-11 \\
R-11 \\
R-0 \\
\text { NA } \\
\text { NA } \\
-- \\
\text { SEER } 10\end{array}$ & $\begin{array}{l}\text { Dbl LOH-E } \\
\text { normal } \\
R-19 \\
R-19 \\
R-19 \\
R-0 \\
\text { NA } \\
\text { NA } \\
-- \\
\text { SEER } 10\end{array}$ & $\begin{array}{l}0.0 \\
2.5 \\
2.5\end{array}$ & $\begin{array}{l}\text { S_W/O TB } \\
\text { nOImal } \\
R-19 \\
R-19 \\
R-11 \\
R-0 \\
\text { NA } \\
\text { NA } \\
\text { S- } \\
\text { SEER } 10\end{array}$ & $\begin{array}{l}\text { Dbl LOW-E } \\
\text { norma! } \\
R-33 \\
R-19 \\
R-28 \\
R-0 \\
\text { NA } \\
\text { NA } \\
\text { SEER } 10\end{array}$ & $\begin{array}{l}5.6 \\
0.0 \\
5.0\end{array}$ & $\begin{array}{l}\text { Dbl TB } \\
\text { nORmal } \\
R-3 D \\
R-19 \\
R-11 \\
R-0 \\
\text { NA } \\
\text { NA } \\
-- \\
\text { SEER } 10\end{array}$ & $\begin{array}{l}\text { Dbl Low-E } \\
\text { normal } \\
R-33 \\
R-19 \\
R-28 \\
R-0 \\
\text { NA } \\
\text { NA } \\
-- \\
\text { SEER } 10\end{array}$ & $\begin{array}{l}1.2 \\
0.0 \\
5.0\end{array}$ \\
\hline $\begin{array}{l}\text { Electric } \\
\text { Heat } \\
\text { Pump }\end{array}$ & $\begin{array}{l}\text { glazing type } \\
\text { infiltration } \\
\text { ceiling insulation } \\
\text { Hall insulation } \\
\text { crawlspace insulation } \\
\text { slab insulation } \\
\text { base. wall insulation } \\
\text { base. floor insulation } \\
\text { heating efficiency } \\
\text { cooling efficiency }\end{array}$ & $\begin{array}{l}\text { Db!_W/o TB } \\
\text { normal } \\
\text { R-19 } \\
\text { R-11 } \\
R-11 \\
R-0 \\
\text { NA } \\
\text { NA } \\
\text { AFUE } 78 \% \\
\text { SEER } 10\end{array}$ & $\begin{array}{l}\text { Dbl_Wfo TB } \\
\text { nornal } \\
R-19 \\
R-13 \\
R-19 \\
R-0 \\
\text { NA } \\
\text { NA } \\
\text { AFUE } 78 \% \\
\text { SEER } 10\end{array}$ & $\begin{array}{l}0.0 \\
0.5 \\
2.5\end{array}$ & $\begin{array}{l}\text { S_W/o TB } \\
\text { normal } \\
R-19 \\
R-19 \\
R-11 \\
R-0 \\
\text { NA } \\
\text { NA } \\
\text { AFUE } 78 \% \\
\text { SEER } 10\end{array}$ & $\begin{array}{l}\text { Db!_W/o TB } \\
\text { nOrmal } \\
R-19 \\
R-17 \\
R-19 \\
R-0 \\
\text { NA } \\
\text { NA } \\
\text { AFUE } 78 \% \\
\text { SEER } 10\end{array}$ & $\begin{array}{r}0.0 \\
-2.5 \\
2.5\end{array}$ & $\begin{array}{l}\text { Dbi TB } \\
\text { normal } \\
R-30 \\
\text { R-19 } \\
R-11 \\
\text { R-0 } \\
\text { NA } \\
\text { NA } \\
\text { AFUE } 78 \% \\
\text { SEER } 10\end{array}$ & $\begin{array}{l}\text { Dbl LOH-E } \\
\text { norma! } \\
\text { R-30 } \\
\text { R-19 } \\
\text { R-28 } \\
R-0 \\
\text { NA } \\
\text { NA } \\
\text { AFUE } 78 \% \\
\text { SEER } 10\end{array}$ & $\begin{array}{l}0.0 \\
0.0 \\
5.0\end{array}$ \\
\hline oil & $\begin{array}{l}\text { glazing type } \\
\text { infiltration } \\
\text { ceiling insulation } \\
\text { wall insulation } \\
\text { crawlspace insulation } \\
\text { slab insulation } \\
\text { base. wall insulation } \\
\text { base. floor insulation } \\
\text { heating efficiency } \\
\text { cooling efficiency }\end{array}$ & NA & NA & & $\mathrm{NA}$ & NA & & NA & NA & \\
\hline
\end{tabular}


TABLE A.I (contd)

\begin{tabular}{|c|c|c|c|c|c|c|c|c|c|c|}
\hline & & $\begin{array}{l}\text { Base line } \\
\text { Ft Worth }\end{array}$ & $\begin{array}{c}\text { ARES } \\
\text { Ft Uorth }\end{array}$ & $\begin{array}{l}\text { Change In } \\
\text { Insulation } \\
\text { (inches) } \\
\text { FG Sheath }\end{array}$ & $\begin{array}{l}\text { Base Line } \\
\text { Albany }\end{array}$ & $\begin{array}{l}\text { ARES } \\
\text { Albany }\end{array}$ & $\begin{array}{l}\text { Change In } \\
\text { Insulation } \\
\text { (inches) } \\
\text { FG Sheath }\end{array}$ & $\begin{array}{l}\text { Base Line } \\
\text { Providence }\end{array}$ & $\begin{array}{c}\text { Ares } \\
\text { Providence } \\
\text { (a) } \\
\end{array}$ & $\begin{array}{l}\text { Change In } \\
\text { Insulation } \\
\text { (inches) } \\
\text { FG Sheath }\end{array}$ \\
\hline Gas & $\begin{array}{l}\text { glazing type } \\
\text { infiltration } \\
\text { ceiling insulation } \\
\text { wall insulation } \\
\text { crawlspace insulation } \\
\text { slab insulation } \\
\text { base. Hall insulation } \\
\text { base. floor insulation } \\
\text { heating efficiency } \\
\text { cooling efficiency }\end{array}$ & $\begin{array}{l}S H / O \text { TB } \\
\text { nOTmal } \\
R-19 \\
R-11 \\
R-11 \\
R-0 \\
\text { NA } \\
\text { NA } \\
\text { AFUE } 78 \% \\
\text { SEER } 10\end{array}$ & $\begin{array}{l}\text { Dbl H/O TB } \\
\text { nOrmal } \\
R-11 \\
R-11 \\
R-14 \\
R-0 \\
\text { NA } \\
\text { NA } \\
\text { AFUE } 78 \% \\
\text { SEER } 10\end{array}$ & $\begin{array}{r}-3.2 \\
0.0 \\
0.7\end{array}$ & $\begin{array}{l}\text { DDbl TB } \\
\text { normal } \\
R-19 \\
R-11 \\
R-11 \\
R-0 \\
\text { NA } \\
\text { NA } \\
\text { AFUE } 78 \% \\
\text { SEER } 10\end{array}$ & $\begin{array}{l}\text { Obl } W / O \text { TB } \\
\text { norma! } \\
\text { R- } 19 \\
R-13 \\
R-19 \\
\text { R-O } \\
\text { NA } \\
\text { NA } \\
\text { AFUE } 85 \% \\
\text { SEER } 10\end{array}$ & $\begin{array}{l}0.0 \\
0.5 \\
2.5\end{array}$ & $\begin{array}{l}\text { Obl H/O TB } \\
\text { normel } \\
R-14 \\
R-11 \\
R-7 \\
R-0 \\
\text { NA } \\
\text { NA } \\
\text { AFUE } 7 B \% \\
\text { SEER } 10\end{array}$ & $\begin{array}{l}\text { Dbl LOH-E } \\
\text { normal } \\
R-19 \\
R-13 \\
R-19 \\
R-0 \\
\text { NA } \\
\text { NA } \\
\text { AFUE } 85 \% \\
\text { SEER } 10\end{array}$ & $\begin{array}{l}2.0 \\
0.5 \\
3.9\end{array}$ \\
\hline $\begin{array}{l}\text { Electric } \\
\text { Foread } \\
\text { Air }\end{array}$ & $\begin{array}{l}\text { giazing type } \\
\text { infiltration } \\
\text { ceiling insulation } \\
\text { wall insulation } \\
\text { crawlspece insulation } \\
\text { stab insulation } \\
\text { base. wall insulation } \\
\text { base. floor insulation } \\
\text { heating efficiency } \\
\text { cooling efficiency }\end{array}$ & $\begin{array}{l}S \mathrm{H} / \mathrm{O} \text { TB } \\
\text { normal } \\
\mathrm{R} \cdot 19 \\
\mathrm{R}-11 \\
\mathrm{R}-11 \\
\mathrm{R}-0 \\
\text { NA } \\
\mathrm{NA} \\
\quad- \\
\text { SEER } 10\end{array}$ & $\begin{array}{l}\text { Obl LOH-E } \\
\text { nOrma! } \\
R-19 \\
R-19 \\
R-19 \\
R-0 \\
\text { NA } \\
\text { NA. } \\
\text { SEER } 10\end{array}$ & $\begin{array}{l}0.0 \\
2.5 \\
2.5\end{array}$ & $\begin{array}{l}\text { Dbl TB } \\
\text { normal } \\
R-19 \\
R-11 \\
R-11 \\
R-0 \\
\text { NA } \\
\text { NA } \\
\text { SEER } 10\end{array}$ & $\begin{array}{l}\text { Dbl LOW-E } \\
\text { normal } \\
R-33 \\
R-19 \\
R-28 \\
R-0 \\
\text { NA } \\
\text { NA } \\
\text { - } \\
\text { SEER } 10\end{array}$ & $\begin{array}{l}5.6 \\
2.5 \\
5.0\end{array}$ & $\begin{array}{l}\text { Dbl W/O TB } \\
\text { normal } \\
8-14 \\
R-11 \\
R-7 \\
R-0 \\
\text { NA } \\
\text { NA } \\
\text { SEER } 10\end{array}$ & $\begin{array}{l}\text { Dbl LOW-E } \\
\text { normal } \\
R-38 \\
R-24 \\
R-2 B \\
\text { R-O } \\
\text { NA } \\
\text { NA } \\
\text { SEER } 10\end{array}$ & $\begin{array}{l}9.9 \\
2.5 \\
6.4\end{array}$ \\
\hline $\begin{array}{l}\text { Electr ic } \\
\text { Heat } \\
\text { Pump }\end{array}$ & $\begin{array}{l}\text { glazing type } \\
\text { infiltration } \\
\text { ceiling insulation } \\
\text { wall insulation } \\
\text { crawlspace insulation } \\
\text { slab insulation } \\
\text { base. wall insulation } \\
\text { base. floor insulation } \\
\text { heating efficiency } \\
\text { cooling efficiency }\end{array}$ & $\begin{array}{l}\text { S H/OTB } \\
\text { normal } \\
\text { R- } 19 \\
R-11 \\
R-11 \\
\text { R-0 } \\
\text { NA } \\
\text { NA } \\
\text { AFUE } 78 \% \\
\text { SEER } 10\end{array}$ & $\begin{array}{l}\text { Dbl } \mathrm{H} / \mathrm{O} \text { TB } \\
\text { normal } \\
\mathrm{R}-19 \\
\mathrm{R}-11 \\
\mathrm{R}-19 \\
\mathrm{R}-0 \\
\text { NA } \\
\text { NA } \\
\text { AFUE } 78 \% \\
\text { SEER } 10\end{array}$ & $\begin{array}{l}0.0 \\
0.0 \\
2.5\end{array}$ & $\begin{array}{l}\text { Dbl TB } \\
\text { normal } \\
R-19 \\
R-11 \\
R-11 \\
R-0 \\
\text { NA } \\
\text { NA } \\
\text { AFUE } 78 \% \\
\text { SEER } 10\end{array}$ & $\begin{array}{l}\text { Db! LOH-E } \\
\text { normal } \\
R-19 \\
R-19 \\
R-22 \\
R-0 \\
\text { NA } \\
\text { NA } \\
\text { AFUE } 90 \% \\
\text { SEER } 10\end{array}$ & $\begin{array}{l}0.0 \\
2.5 \\
3.2\end{array}$ & $\begin{array}{l}\text { Dbl H/O TS } \\
\text { normal } \\
R-14 \\
R-11 \\
R-7 \\
R-0 \\
\text { NA } \\
\text { NA } \\
\text { AFUE } 78 \% \\
\text { SEER } 10\end{array}$ & $\begin{array}{l}\text { Dbl LOW-E } \\
\text { normal } \\
R-19 \\
R-19 \\
R-19 \\
R-0 \\
\text { NA } \\
\text { NA } \\
\text { AFUE } 90 \% \\
\text { SEER } 10\end{array}$ & $\begin{array}{l}2.0 \\
2.5 \\
3.9\end{array}$ \\
\hline Oit & $\begin{array}{l}\text { glazing type } \\
\text { infiltration } \\
\text { ceiling insulation } \\
\text { wall insulation } \\
\text { crawlspace insulation } \\
\text { slab insulation } \\
\text { base. Hall insulation } \\
\text { base. floor insulation } \\
\text { heating efficiency } \\
\text { cooling efficiency }\end{array}$ & NA & NA & & $\begin{array}{l}\text { DbL TB } \\
\text { normal } \\
R-19 \\
R-11 \\
R-11 \\
R-0 \\
\text { NA } \\
\text { NA } \\
\text { AFUE } 78 \% \\
\text { SEER } 10\end{array}$ & $\begin{array}{l}\text { Dbl Low-E } \\
\text { normal } \\
R-30 \\
R-19 \\
R-28 \\
R-0 \\
\text { NA } \\
\text { NA } \\
\text { AFUE } 78 \% \\
\text { SEER } 10\end{array}$ & $\begin{array}{l}4.4 \\
2.5 \\
5.0\end{array}$ & $\begin{array}{l}\text { Dbl W/O TB } \\
\text { nOrmal } \\
R-14 \\
R-11 \\
R-7 \\
R-0 \\
\text { NA } \\
\text { NA } \\
\text { AFUE } 78 \% \\
\text { SEER } 10\end{array}$ & $\begin{array}{l}\text { Dbl LoH-E } \\
\text { normal } \\
R-19 \\
R-11 \\
R-19 \\
R-0 \\
\text { NA } \\
\text { NA } \\
\text { AFUE } 90 \% \\
\text { SEER } 10\end{array}$ & $\begin{array}{l}2.0 \\
0.0 \\
3.9\end{array}$ \\
\hline
\end{tabular}

(a) Rhode Istand has adopted a new, fuel-specific energy code that went into effect on October 1, 1988. Basel ine codes included in this study, however, reflect the code in place in March 1988, which was not fuel specific. 


\section{TABLE A.7 (Cont.)}

\begin{tabular}{|c|c|c|c|c|}
\hline & & $\begin{array}{l}\text { Base Line } \\
\text { Pasadena }\end{array}$ & $\begin{array}{c}\text { Ares } \\
\text { Pasadena } \\
\end{array}$ & $\begin{array}{l}\text { Change In } \\
\text { Insulat ion } \\
\text { (inches) } \\
\text { fG Sheath }\end{array}$ \\
\hline \multirow[t]{9}{*}{ Gas } & $\begin{array}{l}\text { glazing type } \\
\text { infiltration }\end{array}$ & $\begin{array}{l}S \mathrm{~W} / \mathrm{O} T \mathrm{~TB} \\
\text { normal }\end{array}$ & $\begin{array}{l}S \mathrm{~W} / \mathrm{o} T \mathrm{~B} \\
\text { normal }\end{array}$ & \\
\hline & cciling insulation & $R-19$ & $\mathrm{R}-11$ & -3.2 \\
\hline & wall insulation & $R \cdot 7$ & $R \cdot 11$ & 1.4 \\
\hline & cranlspace insulation & $R-7$ & $R-11$ & 1.4 \\
\hline & slab insulation & $R-0$ & $R=0$ & \\
\hline & base. kall insulation & NA & NA & \\
\hline & base. floor insulation & & & \\
\hline & heating efficiency & AFUE $-78 \%$ & AFUE $78 \%$ & \\
\hline & cooling efficiency & SEER-10 & SEER 10 & \\
\hline $\begin{array}{l}\text { Electric } \\
\text { Forced }\end{array}$ & $\begin{array}{l}\text { glazing type } \\
\text { infiltration }\end{array}$ & $\begin{array}{l}S w / O T B \\
\text { normal }\end{array}$ & $\begin{array}{l}5 \mathrm{H} / 0 \mathrm{~TB} \\
\text { normal }\end{array}$ & \\
\hline \multirow[t]{7}{*}{ Ais } & ceiling insulation & $R-19$ & $R-19$ & -0.0 \\
\hline & wall insulation & $R \cdot 7$ & $R-19$ & 3.9 \\
\hline & craulspace insulation & $R-7$ & $R-11$ & 3.9 \\
\hline & slab insulation & $R-0$ & $R-0$ & \\
\hline & base. wall insulation & NA & NA & \\
\hline & base. floor insulation & NA & NA & \\
\hline & cooling efficiency & SEER -10 & SEER 10 & \\
\hline $\begin{array}{l}\text { Elcetric } \\
\text { Keat }\end{array}$ & $\begin{array}{l}\text { glazing type } \\
\text { infiltration }\end{array}$ & $\begin{array}{l}S \mathrm{w} / 0 \mathrm{~TB} \\
\text { normal }\end{array}$ & $\begin{array}{l}\text { Dbl w/O TB } \\
\text { normal }\end{array}$ & \\
\hline \multirow[t]{8}{*}{ Punp } & ceiling insulation & $R-19$ & R-19 & -0.0 \\
\hline & wall insutation & $R-7$ & $R-11$ & 1.4 \\
\hline & crawlspace insulation & $R-7$ & $R=19$ & 3.9 \\
\hline & slab insulation & $R \cdot 0$ & $R=0$ & \\
\hline & base. wall insulation & & NA & \\
\hline & base. floor insulation & & & \\
\hline & heating efficiency & AFUE $-73 \%$ & AFUE $78 \%$ & \\
\hline & cooling efficiency & SEER-10 & SEER 10 & \\
\hline $0 i l$ & glazing type & NA & NA & \\
\hline & $\begin{array}{l}\text { infiltration } \\
\text { cejling insulation }\end{array}$ & & & \\
\hline & kalt insulation & & & \\
\hline & $\begin{array}{l}\text { crasl space insulation } \\
\text { slab insulation. }\end{array}$ & & & \\
\hline & $\begin{array}{l}\text { sab insulation } \\
\text { base. kall insulation }\end{array}$ & & & \\
\hline & base. floor insulation & & & \\
\hline & $\begin{array}{l}\text { heating efriciency } \\
\text { cooling efficiency }\end{array}$ & & & \\
\hline
\end{tabular}




\section{A.3 REFERENCES}

American Gas Association. 1986. Gas Househeating Survey: 1985. Arlington, Virginia.

Amols, G. R., K. B. Howard, A. K. Nicholis, T. D. Guerra. 1988. Residential and Commercial Buildings Data Book: Third Edition. PNL-6454, BattellePacific Northwest Laboratory, Richland, Washington.

MCGraw-Hill Publications, Co. 1985. Electrical World, Directory of Electric Utilities, 1985-1986. New York, New York.

National Appliance Efficiency Conservation Act. 1987. Public Law 100-12, 43 USC 6201.

U.S. Department of Commerce (DOC) and U.S. Department of Housing and Urban Development (HUD). 1986. Characteristics of New Housing: 1985, C-25-85-13. Washington, D. $\overline{\mathrm{C}}$.

U.S. Department of Energy, (DDE), Energy Information Administration. 1987. State Energy Price and Expenditure Report 1985. DDE/EIA-0376(85), Washington, D.C.

U.S. Department of Energy, (DDE), Energy Information Administration. 1986. Housing Characteristics, 1985. DOE/EIA-0314(84), Washington, D.C. 


\section{APPENDIX B}

DEVELOPMENT OF THE BASELINE CASE STUDY RESIDENCES 
APPENDIX B

DEVELOPMENT OF THE BASELINE CASE STUDY RESIDENCES

Levels of energy conservation measures (ECMs) in new homes vary widely across the United States, as a result of local codes, climate, building practices, energy prices, and the extent of consumer awareness. Because of this variation, it was inappropriate to select a single baseline level of efficiency to develop estimates of environmental and economic impacts that could result from adoption and enforcement of the proposed voluntary standard.

Accordingly, a number of baseline ECM packages (at least one for each basic prototype in each study location) were developed. These packages reflect levels of ECMs that represent typical current building practices in each location. Eight of the ten study locations are in states that have mandatory state-wide energy codes. The two remaining locations are in states with model standards or guidelines that provide recommended energy efficiency levels for residences. In these states (Arizona and Texas), recominended ECM levels are mandatory only if adopted by local governments. In neither study location (Phoenix and Fort Worth) was this the case.

\section{B.1 CURRENT ECM LEVELS IN SITE-BUILT HOMES}

Factors that influence the level of ECMs currently used in new site-built housing are discussed in the following sections.

\section{B.1.1 State Energy Codes for Site-Built Homes}

By 1987, thirty-three states had adopted a mandatory energy efficiency code for residential buildings. Most other states adopted model energy codes that are enforced at the discretion of local governments. Most energy codes are based on several prominent model standards that were developed in the late 1970's and early 1980's by such organizations as The American Society of heating, Refrigerating and Air Conditioning Engineers (ASHRAE) and the Council of American Building Officials (CABO), and Building Officials and Code Administrators International, Inc. (BOCA). These parent standards tend to be technically 
similar to one another and to some extent are variations and updates of the original standard, ASHRAE 90-75. Energy efficiencies in these standards are usually expressed as maximum allowable overall themal transmittance values $\left(U_{0}\right)$ for major envelope components and mininum allowable themal resistance values (R) for perimeter insulation of slabs-on-grade (NCSBCS 1985). Criteria are expressed as, or drawn from graphs based on, annual heating degree days.

l'ost states with mandatory codes have made some nodifications to the parent standards in their adoption process. One common approach taken by states is to establish set ECII performance requirenents for the entire state, using a representative value of heating degree days. In other states, several levels of performance are adopted, based on a linited number of geographic (climate) zones. These approaches are taken to avoid the problems of enforcing a code that could fluctuate substantially due to the presence of numerous micro clinates. Other modifications may also be adopted, such as prescribing envelope efficiency performance on the basis of the heating fuel and appliances (and their efficiencies) selected for a new home. State energy codes are reviewec and updated from time to time. Most states have updated the code at least orce since initial adoption (NCSBCS 1985).

Several states (including California, Florida, Hawaii, Louisiana, Nevada, North Carolina, Washington, Oregon and Alaska) have developed their own codes rather than adopting modified versions of the parent standards (although there frequently is a perceptible relationship to the latter). Some of these codes have sophisticated compliance mechanisms using computer software (e.g., the CALPAS progran used as one compliance path in California). Almost all these codes permit compliance via a variety of paths so as not to limit design of and construction techniques for homes.

llost state and local energy codes exist in the form of performance requirements for individual components or combinations of components, with a variety of ways to demonstrate compliance. As performance codes, trade-offs among components (e.g., installing more insulation or a heat pump in order to use a higher window-to-floor area ratio) are comionly allowed and used, especially for custom homes. However, many builders prefer to use a somewhat more prescriptive approach to ECHs (i.e., set levels for each component, that, in 
combination, allow the hore to meet code) in order to comply with energy codes. Therefore, states usually develop illustrative prescriptive compliance paths in addition to performance requirenent levels as a simpler alternative means of compliance.

\section{B.1.2 0ther Factors that Influence ECH Levels in Site-Built Homes}

ECM levels in new homes are also influenced by factors other than model or mandatory energy codes. Consumer awareness of the value of EClls for reducing home energy costs has been steadily increasing since the energy crisis of the 1970 's (see, for example, Hendrickson 1984; Kaiser et al. 1982 and Vines et al. 1987). This awareness has created a demand that gradually has influenced builders to construct new homes that are more energy-efficient. Consumer surveys by such organizations as the NAHB have consistently shown that energy efficiency is a factor of considerable importance among buyers' hame selection criteria (Hendrickson 1984).

In some areas, building practices have also been influenced by utility demand management efforts. Programs to encourage energy efficiency in newlyconstructed homes can often be justified by cost-effectiveness comparisons with traditional generation and other supply resources. In order to qualify for these programs, new homes often must use ECM levels that exceed the applicable state energy codes. These programs are generically referred to as home energy rating systems (HERS). Utilities typically support HERS programs through marketing efforts, consumer awareness campaigns and by providing advertising assistance to participating builders. Many programs now in operation also offer builders or homebuyers cash or energy credits as incentives to build homes to specific performance levels. Utilities also frequently use appliance rebates to encourage builders (and home buyers) to select high-efficiency furnaces, heat pumps, water heaters or solar systens. In a number of areas, utilities clain to have achieved high levels of penetration (40 to 60 percent) of both the single- and multi-family housing markets with their programs. (For further information on these programs see Vines et a1. 1987, Callaway 1986 or Hendrickson 1986.) 
The cross-influence of consumer demand, utility programs and other factors frequently lead to typical levels of efficiency in new site-built construction that exceed present state codes. This is particularly likely in states where the codes are based on the earliest model energy standards and have not been recently updated.

\section{B.2 CURRENT ECM LEVELS IN MANUFACTURED HOMES}

Energy efficiency in manufactured homes is also influenced by both mandetory requirements and consumer demand. The energy efficiency of manufacturec homes (so-called mobile homes or HUD-code hones) $(a)$ is established in a preemptive national standard promulgated by HUD. There are three levels of this standard, corresponding to three climate zones covering the United States, including Alaska. In general, these codes specify ECll performance that is considered to fall below cost-effective levels (Congressional Record H9727, November 6,1987 ). HUD was directed by recent legislation to develop new, cost-effective energy standards for manufactured housing by 1989 .

Consumer demand for energy-efficient housing frequentiy prompts manufacturers of HUD-code housing to offer many models with enhanced energy efficiency features. A recent analysis (Nesse et al. 1987) indicated that ECM levels currently used in the most popular home models exceed the existing HUD standard in many parts of the country.

\section{B.3 DEVELOPHENT OF BASEL INE CODES AND BUILDING PRACTICES}

The variability introduced by existing code requirements and other factors influencing ECI levels required the use of a common approach to guide the baseline development. The approach that was selected was to identify the prevalent ECli efficiency levels in each location. These levels may be those typically. used for compliance with the relevant state code or the predominant building practices used by local builders (primarily nonmandatory-code states). The information was obtained from a telephone survey of code enforcement officials

(a) Constructed in accordance with guidelines established by the U.S. Department of Housing and Urban Development (HUD). 
at the state and local level, builders, architects and utility staff in each study location. This quasi-delphi approach provided estimates for ceiling, foundation and wall insulation; window area; and glazing in new homes.

In mandatory code states, the baseline ECM packages usually represent the state's prescriptive version of the its code. In three locations (Atlanta, Fort Worth and Phoenix), estimated current ECl levels also reflect utiTity HERS requirements, since those prograns have achieved fairly high penetration levels there.

Current practice in manufactured housing for the states containing study locations was estimated from a survey conducted in the 1987 (Nesse et al. 1987). Over 80 manufacturers in 40 states were surveyed by Pacific Northwest Laboratory to identify typical levels of ECris in their most popular single- and double-wide units. In states where there were several respondents, current practice was set at levels representing a simple average for each component.

Baseline prototype homes were modeled by using the estimates of ECM levels drawn from these sources. The results appear in Tables A.5 through A.7 in Appendix $A$. Estimates of the cost and energy use of these homes inciuded an assumption (as does the proposed standard) that space conditioning appliances and hot water heaters in baseline homes would meet the mandatory national mininum requirenents set by the National Appliance Efficiency Conservation Act of 1987 (NAECA).

\section{B.4 REFERENCES}

Callaway, Jenifer W. and K. R. Branch. 1986. Energy Efficient New Homes Prograns: An Analysis of Utility Experience. Prepared for the BonneviTle Power Administration under contract DE-AC06-76RLO 18030. Portland, 0regon.

Hendrickson, Paul L. 1986. Review of Existing Residential Energy Efficiency Certification and Rating Systerns. PNL-6080, Pacific Northwest Laboratory, Richland, Washington.

Kaiser, E. J., M. E. Maisden, and R. Burby. 1982. "The Adoption of Energy Conservation Features in New Homes; Current Practices and Proposed Policies." From Energy and Land Use, Burchell, R. W., and Listokin, D. (eds). Transaction Books, 1980, Rutgers State University, New Brunswick, 08403 . 
National Appliance Efficiency Conservation Act. 1987. Public Law 100-12, 42 USC 6201.

National Conference of States on Building Codes and Standards, Inc. (NCSBCS) 1985. Directory and Comptetion of Technical and Administrative Requirements in Energy Codes for New Building Construction Used Within the United States (Revised). Herndon, Virginia.

National llanufactured Housing Construction and Safety Standards Act. 1974. Public Law , 42 USC 5403(a), 5402(7).

Nesse, R. J., J. W. Callaway, R. F. Darwin, A. D. Lee and S. A. Harkrender. 1988. Analys is of Alternative Housing Energy Standards. PNL-6406, Pacific Northwest Laboratory, Richland, Washington.

Vines, E., B. K. Barnes, and R. Ritschard, 1987. Three Energy Rating Systems: Program Descriptions. LBL-22919, Lawrence Berkeley Laboratory, Berkeley, California. 
APPENDIX C

INDOOR AIR QUALITY ANALYSIS 


\section{APPENDIX C}

\section{INDOOR AIR QUALITY ANALYSIS}

This appendix describes the methods used to compute pollutant levels for six primary pollutants and presents information on the source and character of a number of pollutants that cannot be quantified. For these primary pollutants, information is available to allow computation of the incremental effects that design changes may have on the annual average concentrations in indoor air in residences.

\section{C.1 APPROACH}

Indoor air poliutants can be transported to or released directly into the indoor enviroment from outside sources, building materials, or from occupants or their activities. Considerable information is available about sources and emission rates of such pollutants as particulates, carbon monoxide (CO), carbon dioxide $\left(\mathrm{CO}_{2}\right)$, nitrogen oxides $\left(\mathrm{NO}_{x}\right)$, radon, and formaldehyde. For these six pollutants, quantitative evaluations were made using a computer model to estimate steady-state concentrations of pollutants. For many other pollutants, quantitative information is not as complete, so the estimated incremental change in pollution concentration levels attributable to building design changes were not computed. Qualitative information is provided as a guide in determining if design changes could influence the level of these pollutants.

\section{C.1.1 Computed Pollutant Levels}

Long-term average concentrations of indoor pollutants were modeled for each of the prototype residences for the baseline and for the proposed standard. Both residence ventilation rates and indoor pollutant source terms are required as inputs to the model. Three release rates for each pollutant in each case-study residence were studied: $10 \mathrm{w}$, mediur, and high. The estimates produced by the model bracket the expected range of incremental pollutant concentrations, based on available information and methodologies. 


\section{C.1.2 Nonquantified Pollutants}

Hundreds of pollutants have been identified in residential indoor air. The literature was reviewed for information on these pollutants. of particular interest is the range of chemical compound pollutants found in residential air and the sources for these pollutants, since building materials can be one of those sources. However, except for formaldehyde, little quantitative information is available on these chemicals. Even less empirical information is available about the presence and concentration of microorganisms in residences. Accordingly, no attempt was made to estimate the effect of the proposed standard on the leveis of these pollutants in the home. The latter part of this appendix focuses on factors that influence the presence of chemicals and the growth of microorganisms in the residential environment.

\section{C.2 COMPUTATION METHODOLDGY}

Methods for computing indoor pollutant concentrations that provide reasonable and comparable estimates of indoor air quality across different building types and styles were screened. Those that provided the most reliable estimates without introducing unnecessary complicating factors were selected. The methods are relatively simple and are based primarily on the use of empirical emission factors that were derived from measurements of indoor air quality obtained from recent literature. The use of these factors, combined with the use of consistent ventilation rates for the case study residence's provide a suitable method for assessing incremental indoor air quality differences.

Although the computational methods selected are adequate for indoor air quality comparisons in this assessment, these methods are not necessarily sufficient for evaluating special air quality problems requiring highiy sophisticated models. In general, those more detailed methods require more information on building characteristics, air-handling equipment, emissions, and ambient outdoor concentrations than were available for this study. Examples of such models can be found in documents by the U.S. Environtental Protection Agency (EPA) (1978) and the Electric Power Research Institute $(1981,1985)$. 


\section{C.2.1 Method Used to Evaluate Continuous Sources}

Continuous sources of contaminants were computed using a simple steadystate approach. Emanation rates from soils and building materials for contaminants such as radon and formaldehyde were obtained from the literature; these rates are shown in Table C.1. Continuous rates are usually given as mass emission per time per unit of either a surface area or a mass of material.

Equations for computing pollutant concentrations at steady state are based on a completely mixed single-zone model and take the following general form (typical units are shown below in parentheses):

\begin{tabular}{|c|c|c|c|c|c|c|c|c|c|c|}
\hline $\begin{array}{c}\text { Indoor } \\
\text { Pollutant } \\
\text { Concentration } \\
\text { From Each Source }\end{array}$ & $=$ & $\begin{array}{l}\text { Average } \\
\text { Annual } \\
\text { Outdoor } \\
\text { Concentration }\end{array}$ & + & $\begin{array}{l}\text { Pollutant } \\
\text { Emanation } \\
\text { Rate }\end{array}$ & $x$ & $\begin{array}{l}\text { Mass of } \\
\text { Emanating } \\
\text { Material }\end{array}$ & & $\begin{array}{l}\text { Fresh Air } \\
\text { Exchange } \\
\text { Rate }\end{array}$ & $\div$ & $\begin{array}{l}\text { Building } \\
\text { Volume }\end{array}$ \\
\hline$\left(g / m^{3}\right)$ & $=$ & $\left(g / m^{3}\right)$ & + & {$[(g / k g-h)$} & $x$ & $(\mathrm{~kg})$ & $\div$ & $(1 / h)$ & ${ }^{\prime}$ & $\left.\left(m^{3}\right)\right]$ \\
\hline
\end{tabular}

When 1 iterature surveys indicated a range of values for emanation rates, maximum values are used to determine "worst-case" situations.

The relationship for computing concentration from a number of indoor sources for one pollutant is:

$$
c=c_{0}+\sum_{i}=1, S \frac{\left(E_{i} \times M_{j}\right)}{V \times I}
$$

$$
\text { where } \begin{aligned}
C & =\text { long-term average pollutant concentration }\left(\mathrm{g} / \mathrm{m}^{3}\right), \\
C_{0} & =\text { average annual pollutant concentration in outdoor air }\left(\mathrm{g} / \mathrm{m}^{3}\right), \\
i & =\text { pollutant source material } \\
E_{i} & =\text { emanation rate for pollutant source material }(\mathrm{i} \mathrm{g} / \mathrm{kg}-\mathrm{h}),
\end{aligned}
$$




\section{TABLE C.1. Pollutant Source Terms for Indoor Air Concentration Computations}

\begin{tabular}{|c|c|c|c|c|}
\hline Pollutant & Source & $\begin{array}{c}\text { Emanation Rate } \\
\text { or Concentration } \\
\end{array}$ & Corments & References \\
\hline $\begin{array}{l}\text { Respirable } \\
\text { Particulate } \\
\text { Matter }\end{array}$ & $\begin{array}{l}\text { Tobacco sraking } \\
\text { Gas stove }\end{array}$ & $\begin{array}{l}10.8 \mathrm{mg} / \text { cigarette } \\
0.01 \text { to } 0.03 \mathrm{~g} / \mathrm{hr}\end{array}$ & $\begin{array}{l}\text { Average sidestream } \\
\text { Per burner }\end{array}$ & $\begin{array}{l}\text { NAC } 1981 \mathrm{a} \\
\text { Girman } 1981\end{array}$ \\
\hline $\begin{array}{l}\text { Carbon } \\
\text { Monoxide } \\
(\text { Co) }\end{array}$ & $\begin{array}{l}\text { Tobacco smoking } \\
\text { Gas stove } \\
\text { Respiration }\end{array}$ & $\begin{array}{l}105 \mathrm{mg} / \mathrm{cigarette} \\
1.3 \mathrm{to} 3 \mathrm{~g} / \mathrm{hr} \\
0.2 \mathrm{to} 1.8 \mathrm{~g} / \mathrm{hr} \\
8.9 \mathrm{mg} / \mathrm{sec}\end{array}$ & $\begin{array}{l}\text { Average sidestream plus mainstream } \\
\text { Oven } \\
\text { Per burner } \\
\text { Per person }\end{array}$ & $\begin{array}{l}\text { MRC } 1981 \text { a } \\
\text { Girman } 1981 \\
\text { Cole et al. } 1983\end{array}$ \\
\hline $\begin{array}{l}\text { Carbon } \\
\text { Dloxide } \\
\left(\mathrm{CO}_{2}\right)\end{array}$ & $\begin{array}{l}\text { Tobacco smoking } \\
\text { Gas stove }\end{array}$ & $\begin{array}{l}143 \mathrm{mg} / \text { cigarette } \\
383 \text { to } 400 \mathrm{~g} / \mathrm{hr} \\
483 \text { to } 550 \mathrm{~g} / \mathrm{hr}\end{array}$ & $\begin{array}{l}\text { Average sfdestream plus mainstream } \\
\text { Oven } \\
\text { Per burner }\end{array}$ & $\begin{array}{l}\text { NRC 1981a } \\
\text { Girman } 1981 \\
\text { Gi rman } 1981\end{array}$ \\
\hline \multirow[t]{2}{*}{$\begin{array}{l}\text { Nitric } \\
\text { Oxide (NO) }\end{array}$} & Gas stove & $\begin{array}{l}0.03 \text { to } 0.09 \mathrm{~g} / \mathrm{hr} \\
0.13 \text { to } 0.21 \mathrm{~g} / \mathrm{hr}\end{array}$ & $\begin{array}{l}\text { Oven } \\
\text { Per burner }\end{array}$ & $\begin{array}{l}\text { Girman I981 } \\
\text { Cole et al. } 1983\end{array}$ \\
\hline & Outdoor & $\begin{array}{l}274+\mathrm{g} / \mathrm{m}^{3} \\
48+\mathrm{g} / \mathrm{m}^{3}\end{array}$ & $\begin{array}{l}\text { 1-hr maximum } \\
\text { Rnnual arithmetic mean }\end{array}$ & \\
\hline $\begin{array}{l}\text { Nitrogen } \\
\text { Dioxide } \\
\left(\mathrm{NO}_{2}\right)\end{array}$ & Gas stove & $\begin{array}{l}0.08 \text { to } 0.13 \mathrm{~g} / \mathrm{hr} \\
0.07 \text { to } 0.12 \mathrm{~g} / \mathrm{hr}\end{array}$ & $\begin{array}{l}\text { Oven } \\
\text { Per burner }\end{array}$ & $\begin{array}{l}\text { Girman } 1981 \\
\text { Cole et al. } 198 \text { : }\end{array}$ \\
\hline $\begin{array}{l}\text { Nitrogen } \\
\text { Oxides } \\
\left.\text { (as } \mathrm{NO}_{2}\right)\end{array}$ & Tobacto smoking & $\begin{array}{l}0.13 \text { to } 0.27 \mathrm{~g} / \mathrm{hr} \\
0.25 \text { to } 0.14 \mathrm{~g} / \mathrm{hr} \\
0.065 \mathrm{mg} / \mathrm{cigarette}\end{array}$ & $\begin{array}{l}\text { Dven - calculated from } \mathrm{NO} \text { and } \mathrm{NO}_{2} \\
\text { data } \\
\text { Per hurner - calcutated from } \mathrm{NO} \\
\text { and } \mathrm{NO}_{2} \text { data } \\
\text { Mainstream and sidestream average }\end{array}$ & NRC 1981 \\
\hline 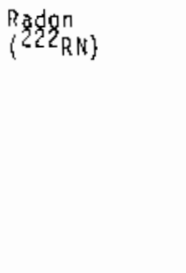 & $\begin{array}{l}\text { Soil } \\
\text { Soil } \\
\text { Soil (under concrete slab) } \\
\text { Soil (under concrete slab) } \\
\text { Concrete } \\
\text { Brick } \\
\text { Wond water } \\
\text { Well water } \\
\text { Surface water }\end{array}$ & $\begin{array}{l}0.1 \text { to } 1 \mathrm{pri} / \mathrm{m}^{2}-\mathrm{sec} \\
1 \text { to } 10 \mathrm{pCi} / \mathrm{m}^{2}-\mathrm{sec} \\
0.01 \text { to } 0.1 \mathrm{prij} / \mathrm{m}^{2}-\mathrm{sec} \\
0.1 \text { to } 1 \mathrm{pCi} / \mathrm{m}^{2}-\mathrm{sec} \\
0.4 \text { to } 1.2 \mathrm{pCi} / \mathrm{kg}-\mathrm{hr} \\
0.10 \text { to } 0.35 \mathrm{pCi} / \mathrm{kg}-\mathrm{hr} \\
0.02 \mathrm{pCi} / \mathrm{kg}-\mathrm{hr} \\
10,000 \mathrm{pCi} / 2 \\
0.014 \mathrm{pCi} / 2\end{array}$ & $\begin{array}{l}\text { Nonmineralized region } \\
\text { Mineralized locality } \\
\text { Nonnineralized region } \\
\text { Mineralized locality } \\
\text { AlT areas of country } \\
\text { lncludes red and adobe } \\
\text { Mean--western wood } \\
\text { Auerage nationwide concentration } \\
\text { Columbia River and tributaries }\end{array}$ & $\begin{array}{l}\text { Bruno 1981 } \\
\text { Bruno } 1981 \\
\text { Bruno } 1981 \\
\text { Bruno } 1981 \\
\text { Hollowe11 } 1981 \\
\text { Hollowell } 1981 \\
\text { Hollowell } 1981 \\
\text { U.S. E.PA } 1979 \\
\text { Soldat } 1961\end{array}$ \\
\hline Organics & $\begin{array}{l}\text { Carpet } \\
\text { New building materials }\end{array}$ & $\begin{array}{l}1.0 \mathrm{mg} / \mathrm{h}-\mathrm{ft} ? \\
10 \mathrm{~g} / \mathrm{h}\end{array}$ & Mominal emission rate & $\begin{array}{l}\text { Miksch } 1982 \\
\text { Miksch } 1982\end{array}$ \\
\hline $\begin{array}{l}\text { Forma ldehyde } \\
\text { (HCHO) }\end{array}$ & $\begin{array}{l}\text { Particle board } \\
\text { Plywood } \\
\text { Paneling } \\
\text { Fiberglass insulations } \\
\text { Clothing } \\
\text { Drapery } \\
\text { Paper oraducts } \\
\text { Carpet } \\
\text { Tobacco smoking } \\
\text { Gas stove }\end{array}$ & 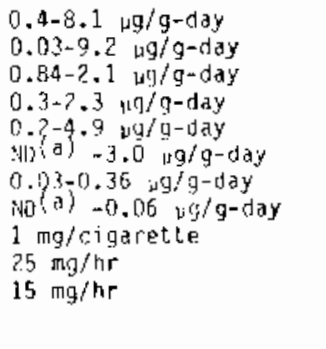 & $\begin{array}{l}\text { Average } \\
\text { Average-oven } \\
\text { Average per burner }\end{array}$ & $\begin{array}{l}\text { Gupta } 1982 \\
\text { Gupta } 1982 \\
\text { Cupta } 1982 \\
\text { Gupta } 1982 \\
\text { Gupta } 1982 \\
\text { Gupta } 1982 \\
\text { Gupta } 1982 \\
\text { Gupta } 1982 \\
\text { NRC 1981 a } \\
\text { NRC 1981 a } \\
\text { NRC 1981a } \\
\text { ARC 1981b }\end{array}$ \\
\hline $\begin{array}{l}\text { Benzo- } \\
\text { [a]-pyrene }\end{array}$ & $\begin{array}{l}\text { Tobacco smoking } \\
\text { Outdoor }\end{array}$ & $\begin{array}{l}0.17 \mathrm{~kg} / \mathrm{c}^{i g .} . \\
0.1 \mathrm{ng} / \mathrm{m}^{3}\end{array}$ & $\begin{array}{l}\text { Average respirable particulates } \\
\text { Average, rural areas - no coking } \\
\text { areas }\end{array}$ & $\begin{array}{l}\text { MRC 1981a } \\
\text { Moschandreas } 1981\end{array}$ \\
\hline
\end{tabular}

(a) $N D=$ not detectable. 


$$
\begin{aligned}
& M_{i}=\text { mass of emanating material for pollutant } i(\mathrm{~kg}), \\
& S=\text { number of sources of the pollutant in the building } \\
& V=\text { volume of building, } \mathrm{m}^{3} \\
& I=\text { the fresh air exchange rate, } 1 / \mathrm{h} .
\end{aligned}
$$

$C_{o}$ is the average annual outdoor concentration, reduced by any air cleaning equipment on the intake air. The fresh air exchange rate is computed for each pollutant using

$$
I=\left(\frac{I+(R \times f)}{V}\right)
$$

where $T=$ the volume of outdoor air supplied per unit time within the building, $\mathrm{m}^{3} / \mathrm{h}$

$$
R=\text { recirculation flow, } \mathrm{m}^{3} / \mathrm{h}
$$$$
f=\text { average removal efficiency for filtration on recirculating }
$$
air, percent $(\%)$

$$
V=\text { volume of building, } m^{3} \text {. }
$$

Using the expressions given above, pollutant concentrations were computed for both the baseline and proposed standard cases. The increment of change in pollutant concentrations between these two cases represents the estimated effect resulting from the use of the proposed standard.

\section{C.2.2 Method Used to Compute Particulate Matter, Carbon Dioxide, Carbon} Monoxide, and Nitrogen Dioxide Concentrations

To estimate contributions of the particulate matter, $\mathrm{CO}_{2}, \mathrm{CO}$ and $\mathrm{NO}_{2}$ from combustion sources, the following equation is used:

$$
c=c_{0}+\frac{\left(E \times t_{1}\right)}{24 h \times 1 \times V}
$$


where $C=$ average daily concentration, $\mathrm{mg} / \mathrm{m}^{3}$

$E=$ the constant source term emission rate, $\mathrm{mg} / \mathrm{h}$

$t=$ the duration of that source term, $h$

1 = the fresh air exchange rate, $1 / \mathrm{h}$

$V=$ the building volume, $\mathrm{m}^{3}$

$C_{0}=$ average annual pollutant concentration in outdoor air, $\mathrm{mg} / \mathrm{m}^{3}$.

The ambient (background) concentration of these pollutants introduced into the. residence may vary from location to location.

\section{C.2.3 Method Used to Compute Radon Concentrations}

Indoor radon concentrations are computed using

$$
C=\frac{S+B+W}{V \times I}+C_{0}
$$

where $\quad C=$ radon concentration, $\mathrm{pCj} / \mathrm{l}$

$\mathrm{S}=$ soil emission rate, $\mathrm{pCi} / \mathrm{h}$

$B=$ building materials emission rate, $\mathrm{pCi} / \mathrm{h}$

$W=$ water emission rate, $\mathrm{pC} i / \mathrm{h}$

$V=$ building volume, $\ell$

$I=$ fresh air exchange rate, $1 / \mathrm{h}$

$\mathrm{C}_{0}=$ average annual ambient outdoor radon concentration, $\mathrm{pC} \mathrm{C} / \mathrm{l}$.

Radon emission rates in Table C.1 are used as typical values. To compute concentration levels, building characteristics, water use, and soil emission rates must be considered. The radon's emission rate from soil into a building depends primarily on the characteristics of the foundation. Table C.1 shows an order-of-magnitude drop in the soil emanation rate into the building when the soil is covered by concrete. Depressurizing the soil under the residence and venting radon directiy to the outdoor environment will also reduce the amount of radon entering the residence. The general formula for computing soil emission rates into a residence is:

$$
S=F \times R \times G \times 3600
$$


where $S=$ radon emission rate, $\mathrm{pCi} / \mathrm{h}$

$F=$ fraction of radon emanating from the soil that enters a structure $(a)$

$R=$ rate of radon emanation from the source, $\mathrm{pCi} / \mathrm{m}^{2}-\mathrm{s}$ (see Table C.1)

$G=$ residence base area, $m^{2}$.

Building material emission rates were computed based on flux-per-unit mass of material in the walls, floors, and ceiling. The general formula is:

$$
B=p_{f} a_{f} t_{f} e_{f}+p_{w} a_{w} t_{w} e_{w}+p_{c} a_{c} t_{c} e_{c}
$$

where $f=$ floor area, $m^{2}$

$w=w a 11$ area, $m^{2}$

$c=$ ceiling area, $m^{2}$

$\mathrm{p}=$ densities of building material, $\mathrm{kg} / \mathrm{m}^{3}$

$a=$ emission surface area, $m^{2}$

$t=$ effective thickness of building material ( $1 / 2$ actual value for exterior walls), m

$\mathrm{e}=$ emanation rate, $\mathrm{pCi} / \mathrm{kg}-\mathrm{h}$.

Well water is the source of almost all of the water-derived radon. Radon levels are very low in surface water, and the radon that is released from this source is usually small compared with that from soil. The formula used for steady-state radon emission rate is: An empirically-derived constant of 0.6 is assumed for the fraction of radon in the water that is released to the indoor environment.

$$
W=0.6 \times U \times E
$$

(a) $F$ is unity (one) for residences built slab-on-grade and with unvented crawl spaces (all radon emanating from the soil is assumed to enter the indoor environment). For residences with basement or vented crawl spaces, $F$ is less than 1 (a fraction of the radon emanating from the soil is assumed to enter the indoor environment; the remaining radon is dispersed to the atmosphere). 
where $W=$ water enission rate, $\mathrm{pC} i / \mathrm{h}$

$\mathrm{U}=$ the average water use per hour in the building, $\ell / \mathrm{h}$

$E=$ radon content of water, $\mathrm{pC} i / \ell$ (Table C.1).

Emanation values given in Table $C .1$ are only guides for computing relative changes in indoor concentration levels. In actual measurements, the radon content of well water, for example, may range over many orders of magnitude. Thus, the release rates of radon from well water must be measured at the site to provide reasonably accurate estinates. Table C.2 contains typical water-use values for certain activities for each member of a family. The use values ma: then be combined with the occupancy to obtain estimates of usage. For specific buildings, the usage per fixture may be used as an alternative computation approach.

Building volume is computed using the physical dimensions of the building's usable area. To estimate indoor radon concentrations, the concentrations resulting from each source alone are computed and added together and to an assumed background value.

TABLE C.2. Water-Use Fixture Rates in Residences

(Golden et al. 1980)

\begin{tabular}{|c|c|}
\hline Water-Use Activity & Fixture Rate \\
\hline \multicolumn{2}{|l|}{ Water-Use Per Fixture } \\
\hline Fill Iavatory & $2 \mathrm{gal} /$ use \\
\hline Fill bathtub & $30 \mathrm{gal} / \mathrm{use}$ \\
\hline Shower/bath & $30-60 \mathrm{gal} / \mathrm{use}$ \\
\hline Flush toilet & $6 \mathrm{gal} /$ use \\
\hline Dishwasher & $3 \mathrm{gal} / 1 \mathrm{oad}$ \\
\hline Automatic Laundry Machine & $30-50 \mathrm{gal} / 1 \mathrm{oad}$ \\
\hline $\begin{array}{l}\text { Average Persona? Use per } \\
\text { Family Melmber (includes } \\
\text { kitchen, laundry and } \\
\text { bath) }\end{array}$ & $40 \mathrm{gal} / \mathrm{day}$ \\
\hline
\end{tabular}




\section{C.2.4 Method Used to Compute Indoor Formaldehyde Concentrations}

Continuous sources of formaidehyde were treated with a simple steady-state approach. Using the emanation rates presented in Table C.1, indoor formaldehyde concentrations may be estimated for the various sources with the equation:

$$
C=C_{0}+\sum_{i=1, n} \frac{F_{j} \times M_{i}}{V \times I}+\frac{W}{V \times I}+\frac{E}{I}
$$

where $\quad C=$ indoor formaldehyde concentration, $\mu \mathrm{g} / \mathrm{m}^{3}$

$F_{j}=$ emission factors for $n$ groups of building and furnishings, $\mu \mathrm{g} / \mathrm{kg}-\mathrm{h}$

$M_{j}=$ mass of building material for ith source, $\mathrm{kg}$

$W=$ wall and ceiling insulation emission rate, $\mu \mathrm{g} / \mathrm{h}$

$E=$ the sum of formaldehyde emanation rate from smoking and gas stoves, $\mu \mathrm{g} / \mathrm{m}^{3}-\mathrm{h}$

$V=$ the volume of the residence, $\mathrm{m}^{3}$

$I=$ fresh air exchange rate, $1 / \mathrm{h}$

$C_{0}=$ average annual outdoor formaldehyde concentration, $\mu \mathrm{g} / \mathrm{m}^{3}$.

The amount of formaldehyde released from insulation is highly variable. Although urea formaldehyde foam insulation (UFFI) is generally not used in new residential buildings, formaldehyde and organic emissions from other types of insulation and building materials that are currently used have been documented (Gupta, Ulsamer and Preuss 1982, Molhave 1982). The total organics emission rates from new building materials decrease as the materials age (Miksch, Hollowell and Schmidt 1982).

The following relationship provides a typical emission rate from insulation:

$$
W=\left(S_{W} \times A_{W}\right)+\left(S_{C}+A_{C}\right)
$$


where $W=$ typical emission rate of wall and ceiling insulation, $\mu \mathrm{g} / \mathrm{h}$ $S_{W}=$ the formaldehyde emission rate from wall insulation, $\mu \mathrm{g} / \mathrm{m}^{2}-\mathrm{h}$

$A_{W}=$ the total insulated wall area computed from the dimensions of the buildings, $\mathrm{m}^{2}$

$S_{C}=$ the formaldehyde emission rate from ceiling insulation, $\mu \mathrm{g} / \mathrm{m}^{2}-\mathrm{h}$

$A_{C}=$ the total insulated ceiling area, $m^{2}$.

Unlike the first two categories above (building materials and UFFI) combustion sources of formaldehyde are intermittent in nature. Therefore, the approach and computational methods are also different. Indoor concentrations of formaldehyde from combustion ( $C$ in Equation $C .11$ below) are determined alorig with a corresponding average air exchange rate (I). From these values, the following relationship is derived:

$$
E_{i}=\left(C_{S} \times I\right)+\left(C_{g} \times I\right)
$$

where $E_{j}=$ derived steady-state emanation of formaldehyde, $\mu \mathrm{g} / \mathrm{m}^{3}-\mathrm{h}$

$\mathrm{C}_{\mathrm{S}}=$ the measured air concentrations from snoking at a known air exchange rate (I), $\mu \mathrm{g} / \mathrm{m}^{3}$

$C_{g}=$ the measured concentrations from an unvented gas stove for a known air exchange rate (I), $\mu \mathrm{g} / \mathrm{m}^{3}$

$I=$ the measured average air exchange rate, $1 / \mathrm{h}$.

Table C.3 sumnarizes the pollutant emission values that were used to bracket possible $1 A Q$ situations in homes (10w, medium and high pollutant emission rates). 
TABLE C.3. Summary of Pollutant Emission Values Used in Computing Indoor Air Quality

\begin{tabular}{|c|c|c|c|c|c|}
\hline Pollutant & Source & Low & Medium & High & Units \\
\hline Radon & Concrete & 0.4 & 0.7 & 1.2 & $\mathrm{pCi} / \mathrm{kg}-\mathrm{h}$ \\
\hline Radon & Red brick & 0.1 & 0.1 & 0.1 & $\mathrm{pCi} / \mathrm{kg}-\mathrm{h}$ \\
\hline Radon & Adobe brick & 0.35 & 0.35 & 0.35 & $\mathrm{pCi} / \mathrm{kg}-\mathrm{h}$ \\
\hline Radon & Drinking water & 10 & 100 & 1,000 & $p C i / \ell$ \\
\hline Radon & Hood & 0.02 & 0.02 & 0.02 & $\mathrm{pCi} / \mathrm{kg}-\mathrm{h}$ \\
\hline Radon & Mix soil & 0.1 & 0.32 & 1 & $\mathrm{pC} i / \mathrm{m}^{2}-\mathrm{s}$ \\
\hline Particulate & Tobacco sm & 10.8 & 10.8 & 10.8 & $\mathrm{mg} /$ cigarette \\
\hline Particulate & Gas stove & 10 & 17 & 30 & mg/burner-h \\
\hline Formal dehyde & Tobacco sm & 1 & 1 & 1 & mgcigarette \\
\hline Formal dehyde & Gas oven & 25 & 25 & 25 & mg/oven-h \\
\hline Formal dehyde & Gas stove & 15 & 15 & 15 & $m g /$ burner-h \\
\hline Formal dehyde & Plywood & 0.03 & 0.5 & 9.2 & $\mu g / g-d a y$ \\
\hline Formal dehyde & Particle board & 0.4 & 1.8 & 8.1 & $\mu \mathrm{g} / \mathrm{g}$ - day \\
\hline Forma 1 dehyde & Fiberglass & 0.3 & 0.8 & 2.3 & $\mu \mathrm{g} / \mathrm{g}-\mathrm{day}$ \\
\hline Forma 1 dehyde & Carpet & 0 & 0 & 0.06 & $\mu g / g-d a y$ \\
\hline $\mathrm{CO}$ & Tobacco sm & 86 & 86 & 86 & mig/cigarette \\
\hline $\mathrm{CO}$ & Gas oven & 1,300 & 2,000 & 3,000 & $\mathrm{mg} /$ oven-h \\
\hline $\mathrm{CO}$ & Gas stove & 200 & 1,000 & 1,800 & mg/burner-h \\
\hline $\mathrm{CO}_{2}$ & Tobacco sm & 80 & 80 & 80 & $\mathrm{mg} /$ cigarette \\
\hline $\mathrm{CO}_{2}$ & Gas oven & 383,000 & 391,000 & 400,000 & $\mathrm{mg} /$ oven-h \\
\hline $\mathrm{CO}_{2}$ & Gas stove & 483,000 & 515,000 & 550,000 & $m g / b u r n e r-h$ \\
\hline $\mathrm{CO}_{2}$ & Respiration & 8.91 & 8.91 & 8.91 & $\mathrm{mg} /$ person-s \\
\hline $\mathrm{NO}_{2}$ & Gas oven & 80 & 105 & 130 & mg/oven-h \\
\hline $\mathrm{NO}_{2}$ & Gas stove & 70 & 95 & 120 & $\mathrm{mg} /$ burner-h \\
\hline $\mathrm{NO}_{2}$ & Tobacco sm & 0.065 & 0.065 & 0.065 & mg/cigarette \\
\hline
\end{tabular}




\section{C.2.5 Fresh Air Ventilation}

The exchange of outside air and indoor air is measured in air changes per hour $(A C H)$. The measure of the air exchange rate of a structure is based on the infiltration of fresh outdoor air expressed in units of volume of air/time. Therefore:

$$
\mathrm{ACH}=\frac{\text { Infiltration Rate, } \mathrm{m}^{3} / \mathrm{hr}}{\text { Building Volume, } \mathrm{m}^{3}}
$$

The principal means of exchanging indoor and outdoor air is through air entering and leaving the envelope of the residence through the naturally occurring cracks and openings. The principal determinants of a building's natural infiltration rate (or air exchange rate) are the amount of cracks and other openings in a building's envelope combined with the temperature differential between indoor and outdoor air, and wind speed that cause the outside air to be exchanged with the inside air.

Other factors influence the air exchange rate including opening windows and doors, use of bath and kitchen ventilation fans, use of a clothes dryer and wood burning. Under special conditions of very low naturally-occurring infiltration rates, mechanical ventilation systems can be incorporated into the design of residential structures to increase the air exchange rate. These include air-to-air heat exchangers and whole-house exhaust-only systems.

\section{C.2.5.1 Air Exchange Rates}

The correlation of residential air exchange rate with construction practices and weather and $c l$ imate parameters is not well understood. Proposed models of air infiltration recognize three independent mechanisms driving air infiltration: 1) the temperature difference between indoors and outdoors causes a pressure differential in the building because of the buoyancy effects (as air is heated it rises and exits pulling cold air into the building from the lower leve1s); 2) wind incident upon a building also creates a pressure differential across the building envelope; and 3) occupant behavior such as opening of doors and windows also contributes to infiltration. The two driving forces related to induced-pressure differential should, in theory, result in 
infiltration rates that are proportional to the leakage area in the building envelope. Leakage areas are difficult to measure directly and are typically inferred from pressurization tests.

A study by Grimsrud, Sherman and Sondregger (1982) summarized annual infiltration rates for over 300 houses with published data in the literature. This sample is biased towards recently constructed, energy-efficient homes. A mean infiltration rate of $0.63 \mathrm{ACH}$ and a median rate of $0.50 \mathrm{ACH}$ were found for the samp?e.

A study by W. S. Fleming and Associates (Nitschke 1985) of the infiltration rate in 60 houses in New York showed a mean of $0.26 \mathrm{ACH}$ for tracer measurements covering an entire year in the sample. The sample was biased toward homes less than 5 years old.

Measurements in over 200 homes in the Pacific Northwest region built since 1984 show a mean air exchange rate of $0.45 \mathrm{ACH}$ for single family housing (BPA 1988), 0.30 for multifarily housing and 0.41 for manufactured housing.

The average infiltration rates for the surveyed homes in various locations do not exhibit any logical relation to the climatic driving forces. In many cases the average rates in milder, less windy climates are higher than those in colder, windier climates. This would suggest that construction practices, rather than climate, are a major determinant of the air exchange rate of new homes. It may be that construction is tighter, on average, in colder climates. Occupancy also affects the air exchange rate in a home. ASHRAE (1985) suggests that occupancy contributes approximately 0.10 to $0.15 \mathrm{ACH}$ to the total measured air exchange rate.

\section{C.2.5.2 Air Exchange Rates Used to Analyze the Proposed Voluntary Standard}

The proposed voluntary standard provides two alternative air change rates (these actually are specifications of the tightness of the construction). The "nornal" package specifies a rate of $0.42 \mathrm{ACH}$ excluding occupant effects. This package conforms to all requirements described in the standard development document (ASHRAE 1987). The normal air change rate is similar to the rates measured in newer homes by BPA (1988). A lower air change rate of $0.27 \mathrm{ACH}$ is 
achieved by selecting the "tight" package in the ARES program. An additional $0.1 \mathrm{ACH}$ for occupant contributions is assumed for both the normal and tight packages, bringing the $\mathrm{ACH}$ totals to 0.52 and $0.37 \mathrm{ACH}$, respectively. The construction requirements for the tight package are also given in the ASHRAE development document (ASHRAE 1987).

\section{C.3 PRESENCE OF NONQUANTIFIED POLLUTANTS}

Residential air contains many pollutants other than the six for which concentrations changes have been estimated. The following sections provide overview information on chemical compounds and microorganisms found in residential indoor air. The techniques and equipment for conducting research on these pollutants are still in an early stage of evolution. Therefore, for chemical or microorganism sources and emanation rates, there is not a large Titerature data base that can be used to accurately predict the extent to which these pollutants may exist in any one residence.

\section{C.3.1 Chemicat Compounds}

Over 300 chemical compounds have been identified in residential air. Several studies have addressed the problem of quantifying the concentrations of chemical compounds in residential air, especially compounds having indoor air concentrations greater than outdoor levels. Compounds identified in five stucies of residential air are shown in Table C.4. This table identifies chemical compounds found in residential indoor air, the ratio of the mean indoor concertration to the outdoor concentration, the mean and maximum indoor concentraticn measured during the sampling period, the Tocation of the residences, and the number of residences evaluated. The residence number in parentheses is the total number of residences tested for that pollutant. For some residences, the pollutant concentrations were below measurable levels.

The presence of chemical compounds in residential air results from one or more of the following sources:

- infiltration of outdoor chenicals

- episodic events (i.e., cooking, cleaning)

- natural consequences of indoor living (respiration, perspiration)

- outgassing from household appliances and building materials. 
TABLE C.4. Chemical Compounds Found in Residential Indoor Air (a)

\begin{tabular}{|c|c|c|c|c|c|}
\hline $\begin{array}{c}\text { Selected Chemlcal } \\
\text { Compound } \\
\end{array}$ & $\begin{array}{c}\text { Indoor-to- } \\
\text { Outdoor } \\
\text { Ratio } \\
\end{array}$ & $\begin{array}{c}\text { Pollut } \\
\text { trat } \\
\text { Mean } \\
\left(\mu g / m^{3}\right)\end{array}$ & $\begin{array}{l}\text { Concen- } \\
\text { Level } \\
\text { Maximum } \\
\left(\mathrm{gg} / \mathrm{m}^{3}\right) \\
\end{array}$ & $\begin{array}{l}\text { Location of } \\
\text { Evaluated ResIdence }\end{array}$ & $\begin{array}{r}\text { Number of }(b) \\
\text { Residences }\end{array}$ \\
\hline Acetaldehyde & 4.9 & 16 & 48 & Northern Italy & 15 \\
\hline Butanal & 2.3 & 15 & 34 & Northern Italy & $3(15)$ \\
\hline Hexanal & 5 & 12 & 20 & Northern Italy & $3(15)$ \\
\hline Nonanol & 5 & 11 & 17 & Northern Italy & $3(15)$ \\
\hline Acetone & 4 & 40 & 157 & Northern Italy & 15 \\
\hline Butanone-2 & 2.7 & 17 & 38 & Northern 1taly & $9(15)$ \\
\hline Trichlorof I uoromethane & 10 & 45 & 230 & Northern Italy & 9 \\
\hline Bromod $1 \mathrm{ch}$ I or omethane & 1.1 & 0.55 & 9 & Greensboro, MC & 20 \\
\hline Dich Ioromethane & 58 & 1290 & 5000 & Northern Italy & $7(8)$ \\
\hline Dichloroethylene & $\begin{array}{l}1.5 \\
1.00\end{array}$ & $\begin{array}{l}0.015 \\
0.025\end{array}$ & $\begin{array}{l}0.062 \\
0.025\end{array}$ & $\begin{array}{l}\text { Baton Rouge, LA } \\
\text { Groensboro, NC }\end{array}$ & $\begin{array}{l}27 \\
20\end{array}$ \\
\hline 1,2-Dlchloroethane & $\begin{array}{l}1.64 \\
1.00 \\
0.89\end{array}$ & $\begin{array}{l}3.6 \\
0.025 \\
0.04\end{array}$ & $\begin{array}{l}69 \\
15 \\
4.74\end{array}$ & $\begin{array}{l}\text { Baton Rouge, LA } \\
\text { Greensboro, NC } \\
\text { Houston, TX }\end{array}$ & $\begin{array}{l}27 \\
20 \\
11\end{array}$ \\
\hline 1,2-0ichloropropane & $\begin{array}{l}2.00 \\
1.00\end{array}$ & $\begin{array}{l}0.01 \\
0.025\end{array}$ & 2.1 & $\begin{array}{l}\text { Baton Rouge, }{ }^{L A} \\
\text { Greensboro, } N C\end{array}$ & $\begin{array}{l}27 \\
20\end{array}$ \\
\hline Chlorotorm & $\begin{array}{l}28.2 \\
4 . i^{2} \\
2.17 \\
2.6 \\
i .6\end{array}$ & $\begin{array}{l}3.67 \\
2.9 \\
7.6 \\
8.5 \\
0.008\end{array}$ & $\begin{array}{l}26 \\
215 \\
47 \\
15 \\
6.4\end{array}$ & $\begin{array}{l}\text { Greensboro, NC } \\
\text { New Jersey } \\
\text { Houston, TX } \\
\text { Northern italy } \\
\text { Baton Rouge, LA }\end{array}$ & $\begin{array}{l}20 \\
355 \\
11 \\
5(14) \\
27\end{array}$ \\
\hline 1,1,1 Trichloroethane & $\begin{array}{l}7.84 \\
3.7 \\
3.5 \\
3.3 \\
2.48\end{array}$ & $\begin{array}{l}20 \\
15.6 \\
6.22 \\
22 \\
1.5\end{array}$ & $\begin{array}{l}31 \\
880 \\
155 \\
60 \\
243\end{array}$ & $\begin{array}{l}\text { Northern ltaly } \\
\text { New Jersey } \\
\text { Greensboro, NC } \\
\text { Baton Rouge, LA } \\
\text { Houston, TX }\end{array}$ & $\begin{array}{l}11 \\
355 \\
20 \\
15 \\
27\end{array}$ \\
\hline Carbon Tetrachloride & $\begin{array}{l}7.0 \\
4.14 \\
1.3 \\
0.70 \\
0.5\end{array}$ & $\begin{array}{l}1.4 \\
0.17 \\
6.9 \\
1.30 \\
0.75\end{array}$ & $\begin{array}{l}14 \\
13 \\
12 \\
3.75 \\
17\end{array}$ & $\begin{array}{l}\text { New Jersey } \\
\text { Greensboro, NC } \\
\text { Northern italy } \\
\text { Houston, TX } \\
\text { Baton Rouge, LA }\end{array}$ & $\begin{array}{l}355 \\
20 \\
15 \\
11 \\
27\end{array}$ \\
\hline Trichloroethylene & $\begin{array}{l}5 \\
3.84 \\
2.6 \\
1.5 \\
1.5\end{array}$ & $\begin{array}{l}0.075 \\
0.096 \\
19 \\
2.0 \\
0.86\end{array}$ & $\begin{array}{l}6.35 \\
2 \\
86 \\
47 \\
1.30\end{array}$ & $\begin{array}{l}\text { Baton Rouge, LA } \\
\text { Greensboro, NC } \\
\text { Northern Italy } \\
\text { New Jersey } \\
\text { Houston, TX }\end{array}$ & $\begin{array}{l}27 \\
20 \\
15 \\
355 \\
11\end{array}$ \\
\hline Tetrachloroethylene & $\begin{array}{l}26.7 \\
2.2^{2} \\
2.01 \\
1.8 \\
1.75 \\
1.2\end{array}$ & $\begin{array}{l}0.40 \\
5.6 \\
1.62 \\
17 \\
2.45 \\
4.1\end{array}$ & $\begin{array}{l}69 \\
250 \\
28 \\
47 \\
34 \\
205\end{array}$ & $\begin{array}{l}\text { Baton Rouge, LA } \\
\text { New Jersey } \\
\text { Greensboro, NC } \\
\text { Northern Italy } \\
\text { Houston, TX } \\
\text { Holl and }\end{array}$ & $\begin{array}{l}27 \\
355 \\
20 \\
15 \\
11 \\
62(134)\end{array}$ \\
\hline 1,4-Dich forobenzene & $\begin{array}{l}35.3 \\
22 \\
12 \\
9.82 \\
3.5 \\
1.02\end{array}$ & $\begin{array}{l}2.12 \\
62 \\
7.2 \\
5.52 \\
2.8 \\
0.09\end{array}$ & $\begin{array}{l}120 \\
230 \\
140 \\
20.6 \\
915 \\
60\end{array}$ & $\begin{array}{l}\text { Baton Rouge, LA } \\
\text { Northern Italy } \\
\text { Holland } \\
\text { Houston, TX } \\
\text { New Jersey } \\
\text { Groensboro, NC }\end{array}$ & $\begin{array}{l}27 \\
9(15) \\
45 \\
11 \\
355 \\
20\end{array}$ \\
\hline
\end{tabular}




\section{TABLE C.4. (contd)}

\begin{tabular}{|c|c|c|c|c|c|}
\hline $\begin{array}{l}\text { Selected Chemical } \\
\text { Compound }\end{array}$ & $\begin{array}{l}\text { Indoor-to- } \\
\text { Outdoor } \\
\text { Ratio } \\
\end{array}$ & $\begin{array}{c}\text { Pollut } \\
\text { trat } \\
\begin{array}{l}\text { Mean } \\
\left(1 \mathrm{~g} / \mathrm{m}^{3}\right)\end{array}\end{array}$ & $\begin{array}{l}\text { Concen- } \\
\text { Level } \\
\text { Maximum } \\
\left(1,19 / m^{3}\right)\end{array}$ & $\begin{array}{l}\text { Location of } \\
\text { Evaluated Residence }\end{array}$ & $\begin{array}{l}\text { Number of }(b) \\
\text { Resldences }\end{array}$ \\
\hline n-Hexane & $\begin{array}{l}21.9 \\
10\end{array}$ & $8 i^{3}$ & $\begin{array}{l}107 \\
590\end{array}$ & $\begin{array}{l}\text { Hol land } \\
\text { Northern Italy }\end{array}$ & $\begin{array}{l}134 \\
13\end{array}$ \\
\hline$n-$ Heptane & $\begin{array}{l}2.8 \\
2.1\end{array}$ & $\begin{array}{l}5.3 \\
19\end{array}$ & $\begin{array}{l}68 \\
76\end{array}$ & $\begin{array}{l}\text { Holland } \\
\text { Northern 1taly }\end{array}$ & $\begin{array}{l}134 \\
13\end{array}$ \\
\hline n-Octane & $\begin{array}{l}6.5 \\
4.3\end{array}$ & $2 i^{2}$ & $\begin{array}{l}60 \\
65\end{array}$ & $\begin{array}{l}\text { Holland } \\
\text { Northern Italy }\end{array}$ & $\begin{array}{l}134 \\
12(13)\end{array}$ \\
\hline n-Nonane & $\begin{array}{l}16 \\
9.2\end{array}$ & $\begin{array}{l}18 \\
30\end{array}$ & $\begin{array}{l}270 \\
165\end{array}$ & $\begin{array}{l}\text { Dutch } \\
\text { Northern Itaiy }\end{array}$ & $\begin{array}{l}133(134) \\
10(13)\end{array}$ \\
\hline n-Decane & $\begin{array}{l}19 \\
5\end{array}$ & $\begin{array}{l}31 \\
25\end{array}$ & $\begin{array}{l}430 \\
1100\end{array}$ & $\begin{array}{l}\text { Holland } \\
\text { Northern 1 taly }\end{array}$ & $133(134)$ \\
\hline n-Undecane & $\begin{array}{l}16 \\
7.5\end{array}$ & $\begin{array}{l}13 \\
93\end{array}$ & $\begin{array}{l}190 \\
950\end{array}$ & $\begin{array}{l}\text { Holland } \\
\text { Northern Italy }\end{array}$ & $\begin{array}{l}129(134) \\
10(13)\end{array}$ \\
\hline n-Dodecane & $3^{15}$ & $1 i^{5}$ & $\begin{array}{l}120 \\
220\end{array}$ & $\begin{array}{l}\text { Holland } \\
\text { Northern Italy }\end{array}$ & $129(134)$ \\
\hline Benzene & $\begin{array}{l}3.9 \\
1.9 \\
1.5\end{array}$ & $\begin{array}{l}52 \\
13 \\
9.9\end{array}$ & $\begin{array}{l}204 \\
120 \\
150\end{array}$ & $\begin{array}{l}\text { Nor thern ltaly } \\
\text { New Jersey } \\
\text { Hol land }\end{array}$ & $\begin{array}{l}15 \\
355 \\
134\end{array}$ \\
\hline Toluene & $\begin{array}{l}6.2 \\
3.4\end{array}$ & $\begin{array}{l}127 \\
55\end{array}$ & $\begin{array}{l}378 \\
700\end{array}$ & $\begin{array}{l}\text { Northern Italy } \\
\text { Holland }\end{array}$ & $\begin{array}{l}15 \\
134\end{array}$ \\
\hline Ethyl benzene & $\begin{array}{l}8.2 \\
1.9 \\
1.7\end{array}$ & $\begin{array}{l}40 \\
6.1 \\
5.0\end{array}$ & $\begin{array}{l}109 \\
320 \\
45\end{array}$ & $\begin{array}{l}\text { Nor thern I taly } \\
\text { New Jersey } \\
\text { Holland }\end{array}$ & $\begin{array}{l}9 \\
355 \\
133(134)\end{array}$ \\
\hline $1,3-x y$ iene \& 1,4-xylene & $\begin{array}{l}7.9 \\
2.9 \\
1.6\end{array}$ & $\begin{array}{l}92 \\
21 \\
15.5\end{array}$ & $\begin{array}{l}390 \\
180 \\
120\end{array}$ & $\begin{array}{l}\text { Northern Italy } \\
\text { Holland } \\
\text { New Jersey }\end{array}$ & $\begin{array}{l}13 \\
134 \\
355\end{array}$ \\
\hline $1,2-x y \operatorname{lene}$ & $\begin{array}{l}3.0 \\
1.7\end{array}$ & $\begin{array}{l}33 \\
5\end{array}$ & $\begin{array}{l}132 \\
4.6\end{array}$ & $\begin{array}{l}\text { Northern I taly } \\
\text { New Jersey }\end{array}$ & $\begin{array}{l}14 \\
355\end{array}$ \\
\hline 1,2,3-Trimethyl benzene & 4.6 & 2.3 & 40 & Holland & $129(134)$ \\
\hline $1,3,5-T r$ Imethy S benzene & $\begin{array}{l}4.5 \\
2.6\end{array}$ & $\begin{array}{l}3.6 \\
19\end{array}$ & $\begin{array}{l}99 \\
59\end{array}$ & $\begin{array}{l}\text { Holland } \\
\text { Northern Italy }\end{array}$ & 9 \\
\hline i, 2,4-Trimethyl benzene & $\begin{array}{l}23 \\
10\end{array}$ & $\begin{array}{r}14 \\
46\end{array}$ & $\begin{array}{l}280 \\
150\end{array}$ & $\begin{array}{l}\text { Holf and } \\
\text { Nor thern Italy }\end{array}$ & $\begin{array}{l}133(134) \\
9\end{array}$ \\
\hline a-Pinene & 21 & 122 & 605 & Northern Italy & 10 \\
\hline Limonene & $\begin{array}{l}54 \\
40\end{array}$ & $\begin{array}{l}38 \\
126\end{array}$ & $\begin{array}{l}216 \\
480\end{array}$ & $\begin{array}{l}\text { Holland } \\
\text { Northern Italy }\end{array}$ & $\begin{array}{l}129(134) \\
13\end{array}$ \\
\hline Napthalene & 4 & $\begin{array}{l}15 \\
1.0\end{array}$ & $\begin{array}{l}70 \\
14\end{array}$ & $\begin{array}{l}\text { Northern Italy } \\
\text { Hol land }\end{array}$ & $\begin{array}{l}3(9) \\
56(134)\end{array}$ \\
\hline Styrene & 2.6 & 1.8 & 54 & New Jersey & 355 \\
\hline Vinylidene Chloride & 0.08 & 0.015 & 12 & Baton Rouge, LA & 27 \\
\hline$n$-Propylbenzene & 3.6 & 1.8 & 27 & Holland & $115(134)$ \\
\hline 1-Propy ibenzene & 2 & 0.7 & 11 & Holland & $68(134)$ \\
\hline o-Methy lethy I ben zene & 4.9 & 4.4 & 72 & Holiand & $129(134)$ \\
\hline m-Methylethyl benzene & 3.9 & 8.7 & 165 & Holl and & $133(134)$ \\
\hline p-Methylethyl ben zene & 4.4 & 4 & 78 & Holl land & $125(134)$ \\
\hline Methylcyclohexane & 2.9 & 2.9 & 50 & Hol ! and & 134 \\
\hline
\end{tabular}




\begin{tabular}{|c|c|c|c|c|c|}
\hline $\begin{array}{l}\text { Selected Chemlcal } \\
\text { Compound } \\
\end{array}$ & $\begin{array}{c}\text { Indoor-to- } \\
\text { Outdoor } \\
\text { Ratlo } \\
\end{array}$ & $\begin{array}{l}\text { Pollutant } \\
\text { tration } \\
\text { Mean } \\
\left(\mathrm{gg} / \mathrm{m}^{3}\right)\end{array}$ & $\begin{array}{l}\text { Concan- } \\
\text { Level } \\
\text { Maxfmum } \\
\left(\mathrm{gg} / \mathrm{m}^{3}\right)\end{array}$ & $\begin{array}{l}\text { Location of } \\
\text { Evaluated Res idence }\end{array}$ & $\begin{array}{r}\text { Number of } \\
\text { Res idences }\end{array}$ \\
\hline Dimethylcyclopentane & 2.0 & 1.0 & 7.8 & Holland & $117(134)$ \\
\hline 3-Methyl pentane & 2,0 & 4.9 & 1.0 & Hol I and & 134 \\
\hline 2-Methyl pentane & 2.0 & 4.3 & 54 & Holl and & 134 \\
\hline 3-Methy / hexane & 1.9 & 3.4 & 44 & Hol t and & 134 \\
\hline Cyclohexane & 4.0 & 2.0 & 22 & Hol land & $130(134)$ \\
\hline n-buty 1 benzene & 8 & 2.3 & 40 & Holl land & $96(134)$ \\
\hline p-Methyl-1-propyl benzene & 5 & 1.6 & 32 & Holland & $110(134)$ \\
\hline$n-T r 1$ decane & 6 & 1.9 & 19 & Holland & $122(134)$ \\
\hline n-Tetradecane & 7 & 2.1 & 8 & Holland & $133(134)$ \\
\hline n-Pentadecane & 5 & 1.5 & 3.6 & Holland & $127(134)$ \\
\hline
\end{tabular}

(a) Lebret et al. 1984; Wallace et al. 1984; Hartwell et al, 1984; DeBortoll et al. 1984; Gammage et ol. 1984 .

(b) Numbers in parentheses are the total numbers of residences tested for that pollutlon; for some residences, the pollutant concentration was below measurable levels.

The following sections provide some information about each of these sources.

\section{C.3.1.1 Infiltration}

Chemical compounds can enter into the residential environment through infiltration of air coming from outside the living space. For example, ambient automobile fumes or vapors of chemicals stored in an attached garage for a long period of time can be important sources of indoor chemical pollutants. Chemical concentrations in soil can be another source; unwanted chemicals disposed of improperly in the soil can be slowly released into the indoor environment through cracks in the foundation.

C.3.1.2 Episodic Events and Household Activities

Episodic events are a major indoor source of chemical pollutants. These are events that are short-lived and involve direct injection of chemicals into the air (i.e. spraying, painting, opening containers). Chemicals can also be generated as a resuit of normal household activities (i.e. cooking, operating self-cleaning oven). The effect of these events on indoor air quality depends 
on whether the activity is normally done in a well-ventilated area. In almost al1 cases, adequate ventilation can be provided by operating kitchen or bathroom fans or by opening windows.

Although adequate ventilation can decrease the effects of chemicals generated from indoor episodic events, the chemicals are of concern for three reasons. First, users might not operate the ventilation devices consistently. Secondly, even trace amounts of organics that escape the ventilation system can be noxious. Finally, harmless organics can react in the indoor environment tc produce irritating or harmful substances. For example, commonly used household hydrocarbons can be induced by sunight to photochemically form aldehydes, ketones, organic acids and free radical intermediates, which cause respiratory discomfort (Meyer 1983).

Three common types of episodic events--consumer products, cooking and cigarette smoking--are discussed in more detail below.

Consumer Products. Common chemical compounds directly injected into household air include petroleum distillates, chlorinated hydrocarbons, ammonium compounds, and many others (see Tabie C.5). Typical sources include aerosol sprays such as deodorants, insecticides, varnishes, window cleaners, meta? cleaners, wall cleaners, and pesticides. The highest exposure to chemical conpounds occurs just after the initial application. Unless proper ventilation is available and used, the chemicals remain in indoor air for long periods of time, a1though at diluted concentrations. Many compounds applied in liquid or solid form can outgas for days because of the low vapor pressure of the chemical ingredients.

Cooking. Carcinogenic organic substances are potentially formed during the cooking of proteins, and the quantity of mutagens appears to be greatest ' $n$ the srioke. Benzo(a)pyrene is a well-publicized carcinogen formed at high tem-peratures, but many others are formed at temperatures as $10 \mathrm{w}$ as $140^{\circ} \mathrm{C}$. For example, several mutagens have been identified in beef cooked at $140^{\circ} \mathrm{C}$ to $190^{\circ} \mathrm{C}$. As much as $99 \%$ of the mutagenic compounds were found in the vapors as opposed to the surface of the meat. The mutagens formed during the cooking of proteins are alt of the same structural type (i.e., 3-ring cyclic molecules with an attached amino group on a carbon adjacent to a ring nitrogen). The 
TABLE C.5. Classification of Organics Found in Homes from Consumer Products (Gossetin et al. 1984)

\begin{tabular}{|c|c|}
\hline Compound & Source \\
\hline Acetates & Adhesives \\
\hline Acetone & Adhesives \\
\hline Acrolein & Overheating Cooking $0 i l s$ and Fats \\
\hline Aniline & Paints/Varnishes \\
\hline Ammonia & $\begin{array}{l}\text { Household Cleaners/Disinfectants } \\
\text { Window Sprays } \\
\text { Plant Fertilizers }\end{array}$ \\
\hline Benzene & $\begin{array}{l}\text { Metal Cleaners } \\
\text { Floor/Wall Cleaners } \\
\text { Paint Brush Cleaners } \\
\text { Paints/Varnishes } \\
\text { Insecticides } \\
\text { Adhesives } \\
\text { Solvents }\end{array}$ \\
\hline Butanol & Paint Thinners \\
\hline Butyl Acetate & Paint Thinners \\
\hline Camphor & Adhesives \\
\hline Ethyl Acetate & Paint Thinners \\
\hline Ethylene GTycol & Cosmetics \\
\hline Chiorobromomethane & Fire Extinguishers \\
\hline Chlorophenols & $\begin{array}{l}\text { Disinfectants } \\
\text { Toilet Bowl Cleaners } \\
\text { Chlorine Bleaches }\end{array}$ \\
\hline Dichloroethane & Dyes \\
\hline Dichloroethylene & $\begin{array}{l}\text { Saran Wrap } \\
\text { Painting Inks } \\
\text { Degreasers } \\
\text { Adhesives }\end{array}$ \\
\hline Diethylenetriamine & Adhesives \\
\hline Diisocyanates & Foan Paddings \\
\hline Dinitrobenzene & Polishes \\
\hline Dioxane & Adhesives \\
\hline
\end{tabular}


TABLE C.5. (contd)

\begin{tabular}{|c|c|}
\hline Compound & Source \\
\hline Ethanol & $\begin{array}{l}\text { Dyes } \\
\text { Rubbing Alcohol } \\
\text { Paints/Varnishes } \\
\text { Air Freshener } \\
\text { Hair Spray }\end{array}$ \\
\hline Ethylene Glycol & Window Cleaners \\
\hline Formal dehyde & Deodorizers \\
\hline Gasoline & $\begin{array}{l}\text { Paints/Varnishes } \\
\text { Adhesives }\end{array}$ \\
\hline Hexane & Adhesives \\
\hline Isopropanol & $\begin{array}{l}\text { Disinfectants } \\
\text { Stain Removers } \\
\text { Deodorizers }\end{array}$ \\
\hline Isoamy/Acetates & Stain Removers \\
\hline Kerosine & $\begin{array}{l}\text { Metal Cleaners } \\
\text { Floor/Wa11 Cleaners }\end{array}$ \\
\hline Methanol & $\begin{array}{l}\text { Stain Removers } \\
\text { Paints/Varnishes } \\
\text { Paint Strippers }\end{array}$ \\
\hline Methylene Chloride & $\begin{array}{l}\text { Aerosol Propellant } \\
\text { Degreaser } \\
\text { Paint/Varnish Stripper } \\
\text { Miticides } \\
\text { Adhesives }\end{array}$ \\
\hline INineral Spirits & $\begin{array}{l}\text { Dyes } \\
\text { Paints/Varnishes } \\
\text { Polishes }\end{array}$ \\
\hline Naptha & $\begin{array}{l}\text { Floor/wall Cleaners } \\
\text { Cigarette Lighters }\end{array}$ \\
\hline Napthalene & Deodorizers \\
\hline Nitrobenzene & Dyes \\
\hline Paradichlorobenzee & $\begin{array}{l}\text { Deodorizers } \\
\text { Cat Spray } \\
\text { Dog Repellant }\end{array}$ \\
\hline Pentachloropheno? & Wood Preservatives \\
\hline Perchloroethylene & $\begin{array}{l}\text { Spot Remover } \\
\text { Prewash Spray }\end{array}$ \\
\hline
\end{tabular}




\section{TABLE C.5. (contd)}

\begin{tabular}{|c|c|}
\hline Compound & Source \\
\hline Pine $0 i 1$ & $\begin{array}{l}\text { Disinfectants } \\
\text { Floor/Wall Cleaners }\end{array}$ \\
\hline Potyurethane & Protective Coatings \\
\hline o-Phenylphenol & Lysol \\
\hline $1,1,1$-Trichloroethane & $\begin{array}{l}\text { Polishes } \\
\text { Drain Cleaners }\end{array}$ \\
\hline Turpentine & $\begin{array}{l}\text { Paints/Varnishes } \\
\text { Polishes }\end{array}$ \\
\hline $\begin{array}{c}\text { Vinyl Acetate } \\
\text { Copolymers }\end{array}$ & Hair Spray \\
\hline Xylenes & $\begin{array}{l}\text { Paint Removers } \\
\text { Degreasers } \\
\text { Lacquers } \\
\text { Glues } \\
\text { Cements } \\
\text { Solvents } \\
\text { Insecticides }\end{array}$ \\
\hline Toluene & $\begin{array}{l}\text { Metal Cleaners } \\
\text { Floor/Wall Cleaners } \\
\text { Adhesives } \\
\text { Paint Thinners } \\
\text { Solvents } \\
\text { Insecticides }\end{array}$ \\
\hline Trichloroethane & $\begin{array}{l}\text { Cleaning Fluids } \\
\text { Decaffeinated Coffee } \\
\text { Metal Cleaners } \\
\text { Dyes } \\
\text { Lubricants } \\
\text { Polishes }\end{array}$ \\
\hline Trichloroethylene & Metal Cleaners \\
\hline
\end{tabular}

health effects of these compounds are mostly unknown, but exposure is easily minimized by using the kitchen ventilation systen during cooking (wishnok 1984).

Cigarette Smoking. Cigarette smoke contains many organic compounds (see Table $C .6)$, including methane (5 mg/cig), C2-C6 hydrocarbons $(2.5 \mathrm{mg} / \mathrm{cig})$, and carbonyls $(1.9 \mathrm{mg} / \mathrm{cig})$. Suspected carcinogens include not only benzo(a)pyrene, but also dibenzo(a)pyrene, benzo(a) anthracene, benzo(b)fluoranthene, 
TABLE C.6. Composition of Organics in Mainstream and Sidestream Smoke (National Research Counci] 1981b)

\begin{tabular}{|c|c|c|c|}
\hline Characteristic or Compound & \multicolumn{2}{|c|}{$\begin{array}{l}\text { Concentration } \\
\text { (mg/cigarette) }\end{array}$} & $\begin{array}{l}\text { Concentration } \\
\text { Ratio }\end{array}$ \\
\hline \multicolumn{4}{|l|}{ General Characteristics: } \\
\hline $\begin{array}{c}\text { Duration of smoke } \\
\text { production, } s\end{array}$ & 20 & 550 & 27.5 \\
\hline Tobacco burned & 347 & 411 & 1.2 \\
\hline $\begin{array}{l}\text { Particles, no. per cigarette } \\
\text { Particles: }\end{array}$ & $1.05 \times 10^{12}$ & $3.5 \times 10^{12}$ & 3.3 \\
\hline Tar (chloroform extract) & $\begin{array}{l}20.8 \\
1.2\end{array}$ & $\begin{array}{l}44.1 \\
34.5(c)\end{array}$ & $\begin{array}{l}2.1 \\
3.4\end{array}$ \\
\hline Nicotie & $\begin{array}{l}0.92 \\
0.46\end{array}(\mathrm{c})$ & $\begin{array}{l}1.69 \\
1.27(c)\end{array}$ & $\begin{array}{l}1.8 \\
2.8\end{array}$ \\
\hline Benzo[a]pyrene & $\begin{array}{l}3.5 \times 10^{-5} \\
4.4 \times 10^{-5}\end{array}$ & $\begin{array}{l}1.35 \times 10^{-4} \\
1.99 \times 10^{-4}\end{array}$ & $\begin{array}{l}3.9 \\
4.5\end{array}$ \\
\hline Pyrene & $\begin{array}{l}1.3 \times 10^{-4} \\
2.70 \times 10^{-4}\end{array}$ & $\begin{array}{l}3.9 \times 10^{-4} \\
1.011 \times 10^{-3}\end{array}$ & $\begin{array}{l}3.0 \\
3.7\end{array}$ \\
\hline Fluoranthene & $2.72 \times 10^{-4}$ & $1.255 \times 10^{-3}$ & 4.6 \\
\hline Benzo[a]f1uorene & $1.84 \times 10^{-4}$ & $7.51 \times 10^{-4}$ & 4.1 \\
\hline Benzo $[b / c]$ fiuorene & $6.9 \times 10^{-5}$ & $2.51 \times 10^{-4}$ & 3.6 \\
\hline Chrysene, benz[a]anthracene & $1.91 \times 10^{-4}$ & $1.224 \times 10^{-3}$ & 6.4 \\
\hline Benzo $[\mathrm{b} / \mathrm{k} / \mathrm{j}] \mathrm{f} 1$ uoranthrene & $4.9 \times 10^{-5}$ & $2.60 \times 10^{-4}$ & 5.3 \\
\hline Benzo[e]pyrene & $2.5 \times 10^{-5}$ & $1.35 \times 10^{-4}$ & 5.4 \\
\hline Perylene & $9.0 \times 10^{-6}$ & $3.9 \times 10^{-5}$ & 4.3 \\
\hline Dibenz $[a, j]$ anthracene & $1.1 \times 10^{-5}$ & $4.1 \times 10^{-5}$ & 3.7 \\
\hline $\begin{array}{l}\text { Dibenz }[\mathrm{a}, \mathrm{h}] \text { anthracene, } \\
\text { ideno-[2,3-ed]pyrene }\end{array}$ & $3.1 \times 10^{-5}$ & $1.04 \times 10^{-4}$ & 3.4 \\
\hline Benzo[ghi]perylene & $3.9 \times 10^{-5}$ & $9.8 \times 10^{-5}$ & 2.5 \\
\hline Anthanthrene & $2.2 . \times 10^{-5}$ & $3.9 \times 10^{-5}$ & 1.8 \\
\hline Phenols (total) & 0.228 & 0.603 & 2.6 \\
\hline Cadmium & $1.25 \times 10^{-4}$ & $4.5 \times 10^{-4}$ & 3.6 \\
\hline
\end{tabular}


TABLE C.6. (contd)

\begin{tabular}{|c|c|c|c|}
\hline \multirow[b]{2}{*}{ Characteristic or Compound } & \multicolumn{2}{|c|}{$\begin{array}{l}\text { Concentration } \\
\text { (mg/cigarette) }\end{array}$} & \multirow[b]{2}{*}{$\begin{array}{l}\text { Concent cation } \\
\text { Ratio }\end{array}$} \\
\hline & $\begin{array}{l}\text { Mainstream } \\
\text { Smoke (1) }\end{array}$ & $\begin{array}{l}\text { Sidestream } \\
\text { Smoke (2) }\end{array}$ & \\
\hline \multicolumn{4}{|l|}{ Gases and Vapors } \\
\hline Water & $7.5^{(d)}$ & $298(e)$ & 39.7 \\
\hline Carbon monoxide & $\begin{array}{l}18.3 \\
--\end{array}$ & $\begin{array}{l}86.3 \\
72.6\end{array}$ & $\begin{array}{r}4.7 \\
--\end{array}$ \\
\hline Ammonia & 0.16 & 7.4 & 46.3 \\
\hline Carbon dioxide & 63.5 & 79.5 & 1.3 \\
\hline $\mathrm{NO}_{\mathrm{X}}$ & 0.014 & 0.051 & 3.6 \\
\hline Hydrogen cyanide & 0.24 & 0.16 & 0.67 \\
\hline Acrolein & $\begin{array}{l}0.084 \\
--\end{array}$ & $\overline{0.825}$ & -- \\
\hline Formal dehyde & - & 1.44 & -- \\
\hline Toluene & 0.108 & 0.60 & 5.6 \\
\hline Acetone & 0.578 & 1.45 & 2.5 \\
\hline Polonium 210, pCi & $0.04-0.10$ & $0.10-0.16$ & $1-4$ \\
\hline
\end{tabular}

(a) Unless otherwise noted.

(b) Sidestream smoke concentration + mainstream smoke concentration.

(c) Filtered cigarettes.

(d) $3.5 \mathrm{mg}$ in particulate phase, rest in vapor phase.

(e) $5.5 \mathrm{mg}$ in particulate phase, rest in vapor phase.

benzo(j)fluoranthene, and indeno(1,2,3-cd)pyrene. The smoker inhales the largest concentration of these contaminants; however, sidestream cigarette smoke is a major contributor to indoor pollution (Meyer 1983). Because smoking is a voluntary activity, the best mitigation strategy is to smoke in wellventilated areas.

\section{C.3.1.3 Natural Consequences of Indoor Living}

Many chemical contaminants are associated with normal human biological processes (see Table C.7), but they also contribute to indoor air pollution. These compounds generally are eliminated by natural air exchange. Some scientists argue that chemicals emitted from the human body can be tolerated at 
relatively high exposures, but many scientists do not believe that external exposures can be generalized from the amount of chemicals the body generates. Since DNA repair enzymes are limited in our bodies, even our own naturally occurring organic metabolites can possibiy cause cancer in much the same way that naturally occurring radiation in the body causes cancer (Environmental Science and Technology 1984).

\section{C.3.1.4 Outgassing of Building Materials and Household Furnishings}

Long-term emission of chemical contaminants from building materials and household furnishings can occur by two mechanisins. Residual solvents and agents such as catalysts, surfactants, or plastic monomers can be released slowly over time or produced slowiy as a result of degradation by air oxidation, photoinitiation, or retropolymerization reactions. Contamination from these mechanisms will be greatest in homes with reduced air exchange rates.

A recent study by Moihave (1982) concluded that building materials may bia the main source of many organic compounds in the indoor home environment. In

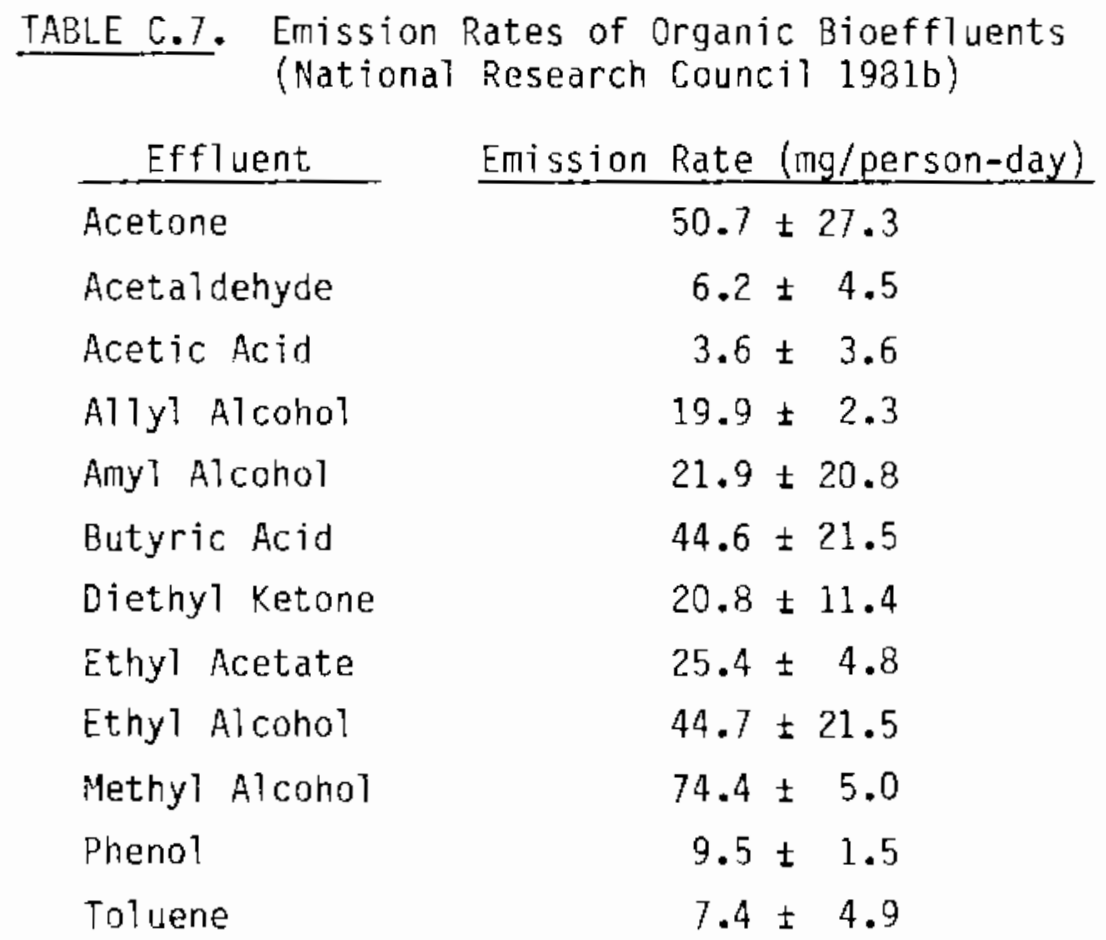


this study, the main sources of organic gases and vapors from building materials were products related to flooring (filler, glue, carpet). Painting and sealing agents were of minor importance.

The Molhave (1982) study measured emissions of organics from 42 commonly used building materials (see Table C.8). Over 52 different compounds were identified (see Table C.9). About $68 \%$ of the compounds were aliphatic or aromatic hydrocarbons, and the remainder were ketones, alcohols, esters, aldehydes, and halogenatedalcanes.

Table C.10 summarizes the measurement results for each type of building material. The emission rates in Columns 3 and 4 represent the sum for all individual contaminants detected or identified; specific concentration and emission rates were not determined for each contaminant. The average concentration for organic gases was $3.2 \mathrm{mg} / \mathrm{m}^{3}$, and the average emission rate was $0.25 \mathrm{mg} / \mathrm{m}^{2}-\mathrm{hr}$. The table also categorizes the potential health effects of the compounds in the study. About $82 \%$ of the compounds were suspected irritants, $25 \%$ were suspected carcinogens, and $30 \%$ had odor thresholds below study concentrations.

The ten most commonly occurring compounds are listed in Table C.11. Also shown are the compounds found to have the highest average air concentration. Toluene, 2-xylene, and 3-xylene are found in both categories.

A recent study by Lawrence Berkeley Laboratories (LBL) (Hodgson et al. 1983) supports the conclusions of the Molhave study (1982). The LBL study also identified the contaminants from several building construction and interiorfinish materials (Table C.12). These included a variety of floor, wall, and ceiling treatments, structural or insulating construction materials, and adhesives (used for bonding carpets, vinyl floors, subfloor assemblies, and other miscellaneous applications). Sixty-eight major compounds were identified in these materials, as shown in Table $\mathrm{C.12}$. The most frequently occurring compounds are footnoted. Compounds emitted by individual building construction and interior finish materials are listed by component in Table C.13, while compounds emitted by adhesives are listed in Table C.14. Many minor compounds 
TABLE C.8. The 42 Materials Studied and the Classification of Their Normal Use (Molhave 1982)

\begin{tabular}{|c|c|c|c|}
\hline No. & Type of Material & Description & $\begin{array}{r}\text { Type of } \\
\text { Material }\end{array}$ \\
\hline 1 & Particle board & Urea-formaldehyde glued & 3 \\
\hline 2 & Particle board & Urea-formaldehyde glued & 3 \\
\hline 3 & Plaster board & 12 man, paper-coated & 3 \\
\hline 4 & Calcium silicate board & $22.8-\mathrm{mm}$ board & 3 \\
\hline 5 & Sealing agent & Plastic, compound & 5 \\
\hline 6 & Searing agent & Plastic, silicone compgund & 5 \\
\hline 7 & Seaiing agent & Putty, strips $5 \times 7 \mathrm{~mm}^{2}$ & 5 \\
\hline 8 & Insulation batch & Mineral wool & 3 \\
\hline 9 & Particle board & Urea-formal dehyde glued & 3 \\
\hline 10 & Plywood lining & Teak & 3 \\
\hline 11 & Woodfiber board & 12-mm board & 3 \\
\hline 12 & Tightening fillet & Neoprene/polyethylene & 5 \\
\hline 13 & Tightening fillet & Plasticized PVC/polyethene & 5 \\
\hline 14 & Felt carpet & Synthetic fibers/plastic backing & 1 \\
\hline 15 & Felt carpet & Synthetic fibers & 1 \\
\hline 16 & Wallpaper & Vinyl and paper & 3 \\
\hline 17 & Wallpaper & Vinyl and glass fibers & 3 \\
\hline 18 & Wallpaper & Printed paper & 3 \\
\hline 19 & Floor covering & Linoleur & 1 \\
\hline 20 & Wall and floor glue & Water-based PVA (poly vinyl acetate) & 3 \\
\hline 21 & Texture glue & Hater-based PVA & 1 \\
\hline 22 & Filler & PVA glue/cement & 3 \\
\hline 23 & Filler & Sand, cement, water-based hardener & 3 \\
\hline 24 & Wall covering & Hessian & 3 \\
\hline 25 & Floor covering & $\begin{array}{l}\text { Synthetic fibers/PVC (poly vinyl } \\
\text { chloride) }\end{array}$ & 1 \\
\hline 26 & Floor covering & Rubber & 1 \\
\hline 27 & Wallpaper & PVC foam & 3 \\
\hline 28 & Tightening fillet & Heat expanding neoprene & 5 \\
\hline 29 & Fiber board & Glass fiber reinforced polyester & 4 \\
\hline 30 & Paint & Acryllatex & 3 \\
\hline 31 & Floor varnish & Epoxy, clear & 1 \\
\hline 32 & Floor varnish & 2-component, isocyanate & 1 \\
\hline 33 & Floor varnish & Acid hardener & 1 \\
\hline 34 & Hall covering & PVC & 3 \\
\hline 35 & Laminated board & Plastic & 4 \\
\hline 36 & Floor covering & Soft plastic & 1 \\
\hline 37 & Insulation foam & Polystyren & 3 \\
\hline 38 & Insulation foam & Polyurethane & 3 \\
\hline 39 & Floor covering & Honogeneous PVC & 1 \\
\hline 40 & Floor and wall covering & Textile & 3 \\
\hline 41 & Floor and wall covering & Textile & 3 \\
\hline 42 & Cement flag & Concrete & 3 \\
\hline
\end{tabular}

(a) 1 - floor only, 2 - floor and ceiling, 3 - walls, 4 - casing, frames, sills, 5 - sealings, putty, etc. 
TABLE C.9. The 52 compounds Identified in the Air Around 42 Common Buflding Materials (Molhave 1982)

Compound

\begin{tabular}{|c|}
\hline 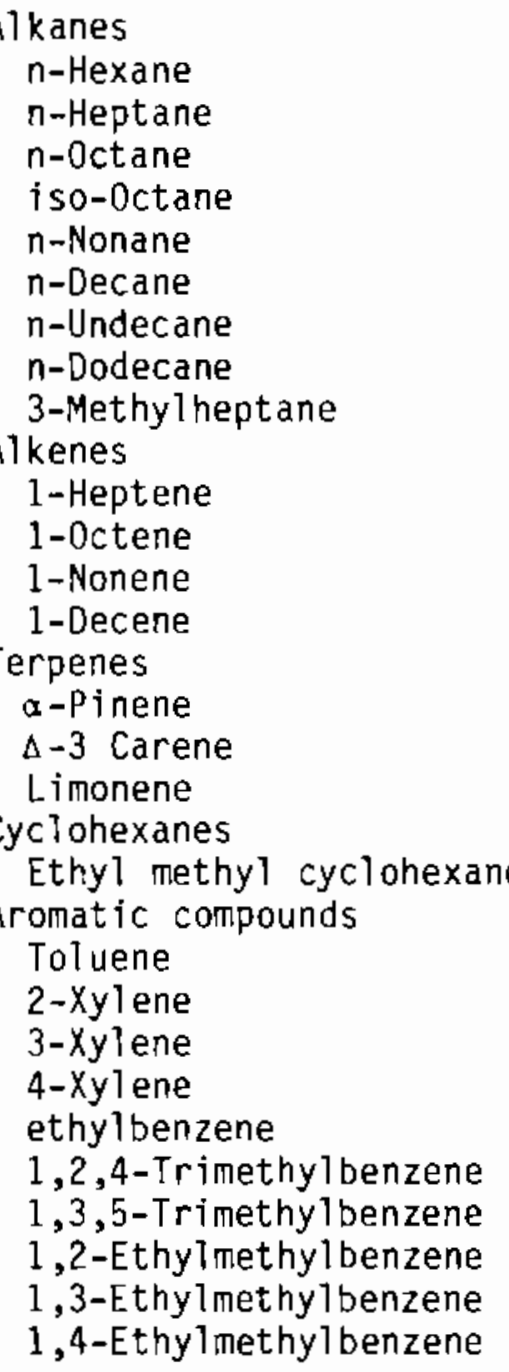 \\
\hline
\end{tabular}

Compound

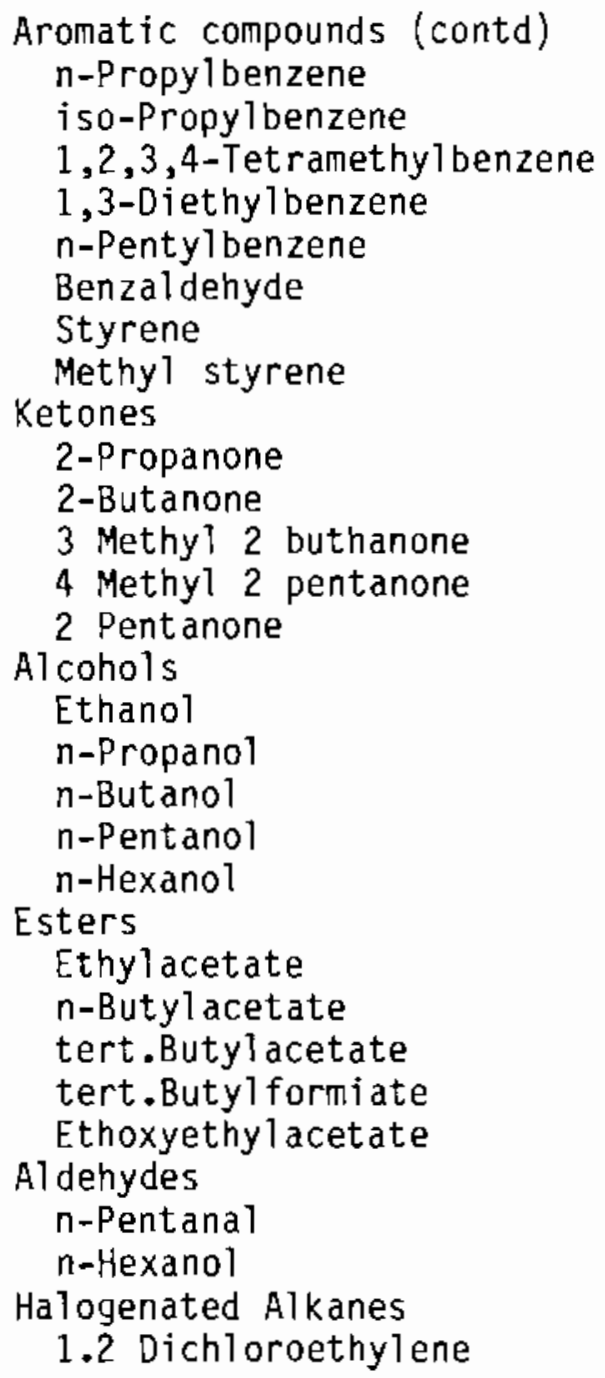

were also identified but they were not listed by Hodgson et al. (1983) because they were assumed to be of lesser importance. Emission rates have not yet been determined by LBL for the individua? components because of the complexity of such a study.

The number of volatile compounds varied greatly among the building materials, but the most frequently occurring was dibutyl phthalate and $2,2,4$ trimetyl-1,3-pentanedial di-i-butyrate. Toiluene, styrene, and a variety of normal and cyclic alkanes were identified in the adhesives. Emission rates for 
TABLC ..10. Analysis of the Air Around 42 Building Materials(a) (Molhave 1982)

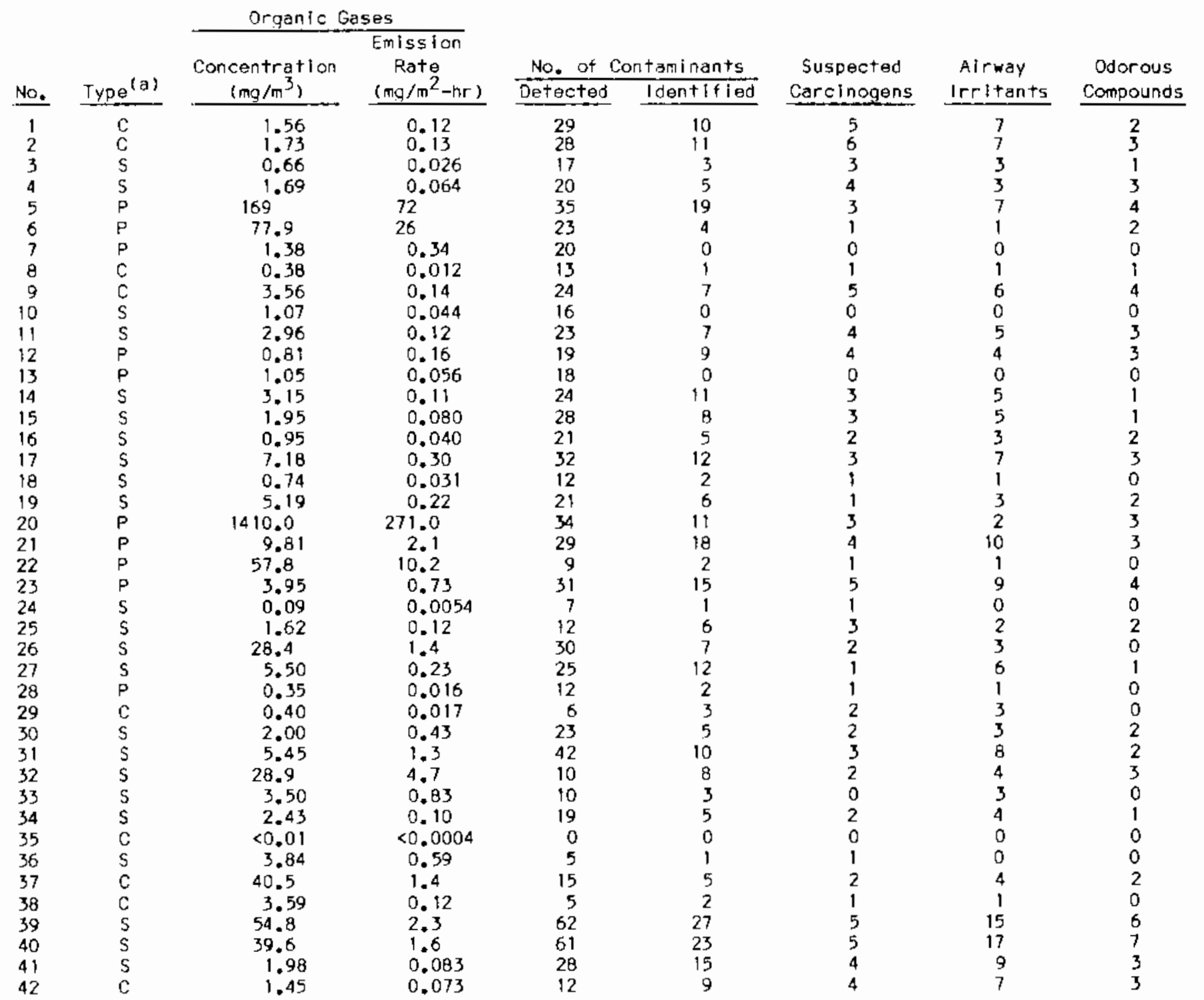

(a) Type of material: $C=$ used inside the construction; $S=$ used on surface; $P=$ putty or sealing compound. 
TABLE C.11. Ten Most Commoniy Occurring Compounds and Compounds with Highest Average Air Concentration in the 42 Materials (Molhave 1982)

\begin{tabular}{|c|c|c|}
\hline Compound & $\begin{array}{c}\text { Average } \\
\text { Concentragtion } \\
\left(\mu \mathrm{g} / \mathrm{m}^{3}\right) \\
\end{array}$ & Frequency \\
\hline \multicolumn{3}{|l|}{ Most Common } \\
\hline Toluene & 39.7 & 22 \\
\hline n-Decane & 1.49 & 20 \\
\hline $1,2,4$-Trimethyl benzene & 0.56 & 18 \\
\hline n-Undecane & 1.00 & 17 \\
\hline 3-xylene & 23.0 & 16 \\
\hline $2-x y 1$ ene & 3.81 & 14 \\
\hline n-Propyl benzene & 0.20 & 13 \\
\hline Ethyl benzene & 1.79 & 12 \\
\hline n-Nonane & 1.05 & 11 \\
\hline 1,3,5-Trimethyl benzene & 0.36 & 11 \\
\hline \multicolumn{3}{|l|}{ Highest Air Concentration } \\
\hline Tolvene & 39.7 & 22 \\
\hline $3-x y l e n e$ & 23.0 & 16 \\
\hline $\mathrm{C}_{10} \mathrm{H}_{16}$ (Tегрепе) & 20.8 & 6 \\
\hline n-Butyl acetate & 15.2 & 1 \\
\hline n-Butanol & 9.4 & 5 \\
\hline n-Hexane & 8.8 & 5 \\
\hline $4-x y l$ ene & 7.3 & 8 \\
\hline Ethoxyethylacetate & 5.9 & 1 \\
\hline n-Heptane & 5.0 & 2 \\
\hline $2-x y l e n e$ & 3.8 & 14 \\
\hline
\end{tabular}

total aikanes and toluene were determined for various adhesives and ranged from 0.6 to $60 \mathrm{\mu g} / \mathrm{g}-\mathrm{hr}$ for solvent-based products and 600 to $800 \mathrm{\mu g} / \mathrm{g}-\mathrm{hr}$ for waterbased products. 
TABLE C.12. Major Compounds Emitted by Building Construction and Interior Finish Materiais (Hodgson et al. 1983)

\begin{tabular}{|c|c|c|}
\hline No. & $\begin{array}{l}\text { Molecular } \\
\text { Weight }\end{array}$ & Chemical Identification \\
\hline 1 & 94 & Phenol \\
\hline 2,1 & 104 & Styrene \\
\hline $3(a)$ & 106 & Ethyl benzene \\
\hline $4(a)$ & 106 & $0-x y 7$ ene \\
\hline $5^{(a)}$ & 106 & $\bar{m}-x y l e n e$ \\
\hline 6 & 128 & Naphtha? ene \\
\hline${ }_{0}^{7}(a)$ & 134 & Benzene, 1 -methy $1-4-(1-$ methylethy 1$)-$ \\
\hline $8^{(a)}$ & 136 & -Pinene \\
\hline $9(2)$ & 136 & Camphene \\
\hline $10^{(\mathrm{a})}$ & 136 & Limonene \\
\hline 11 & 140 & 2-Nonenal \\
\hline 12 & 142 & Nonanal \\
\hline 13, & 142 & Napththalene, 1-methy? \\
\hline $14^{(a)}$ & 144 & Butyl butyrate \\
\hline $15(2)$ & 146 & 2-Ethyl hexanol \\
\hline $16^{(a)}$ & 150 & Thymol \\
\hline 17 & 150 & Phenol, 4-(1,1-dimethylethy $)$ - \\
\hline 18, & 152 & 2-Cyclohexen-1-one, 6-methy $-3-(1-$ methylethy 1$)-$ \\
\hline 19 (a) & 154 & -Terpineol \\
\hline 20 & 154 & 7-0xabicyclo[2.2.1]heptane, 1-methyl-4-(1-methylethy $)-$ \\
\hline 21 & 156 & Naphthalene, 1,4-dimethy?- \\
\hline 22 & 158 & Benzene, 3-cyclohexen-1-yl- \\
\hline 23 & 164 & Benzoic acid, 4-(1-methylethyl)- \\
\hline $24(1)$ & 170 & 2-Hydroxy bipheny1 \\
\hline $25(a)$ & 178 & Benzene propanoic acid, B,B-dimethyl- \\
\hline 26 (a) & 180 & Phenol, $(1,1-$ dimethylethy $)-4$-methoxy- \\
\hline $27(a)$ & 182 & Benzophenone \\
\hline $28(a)$ & 186 & 1-Dodecanol \\
\hline $29+1)$ & 190 & 2-Phenyl octane \\
\hline 30 (a) & 192 & Butanoic acid, $4-\left(2,5-x y 7 y^{1}\right)-$ \\
\hline 31 (a) & 194 & Dimethyl phthalate \\
\hline 32 & 194 & Benzene, 1,4-dimethoxy-2,3,5,6-tetramethyl- \\
\hline 33 & 196 & 1,4-Benzoquinone, 2,6-bis (1,1-dimethylethyl)- \\
\hline 34 & 196 & Octyl cyclohexane \\
\hline 35 & 196 & Benzene, 1,2-dimethyl, 4-benzyl- \\
\hline 36 & 198 & Phenyl benzoic acid \\
\hline $37^{(a)}$ & 198 & $n$-Tetradecane \\
\hline 38 & 210 & Nonyl cyclohexane \\
\hline 39 & 210 & Pentadecene \\
\hline $40^{(d)}$ & 212 & n-Pentadecane \\
\hline 41 & 218 & 5 -Phenyl decane \\
\hline $42(\mathrm{a})$ & 222 & Diethyl phthalate \\
\hline 43 & 224 & Decyl cyclohexane \\
\hline 44 & 226 & 4-Ethyi tetradecane \\
\hline
\end{tabular}


TABLE C.12. (contd)

\begin{tabular}{|c|c|c|}
\hline №. & $\begin{array}{l}\text { Molecular } \\
\text { Weight }\end{array}$ & Chemical Identification \\
\hline & 226 & 2-Methyl pentadecane \\
\hline $46(a)$ & 226 & n-Hexadecane \\
\hline 47 & 232 & 5 -Phenyl undecane \\
\hline 48 & 234 & Phenol, 2,6-bis (1,1-dimethylethy 1)-4-ethyl- \\
\hline 49 & 236 & Indane, $1,1,3-$ trimethy $1-3$-pheny?- \\
\hline 50 & 238 & Undecyl cyclohexane \\
\hline $51^{(a)}$ & 238 & Heptadecene \\
\hline 52 & 240 & 2-Methyl hexadecane \\
\hline $53^{(a)}$ & 240 & $\underline{n}$-Heptadecane \\
\hline 54 & 246 & Decyl xylene \\
\hline 55 & 252 & Octadecene \\
\hline 56 (a) & 254 & n-Octadecane \\
\hline $57(\mathrm{a})$ & 268 & Pristane \\
\hline $58(a)$ & 268 & $\mathrm{n}$-Nonadecane \\
\hline 59 & 272 & Thunbergene $\left(\mathrm{C}_{20} \mathrm{H}_{32}\right.$ branched cycloalkene) \\
\hline $60(\mathrm{a})$ & 278 & Dibutyl phthalate \\
\hline $61^{(a)}$ & 278 & Di-i-butyl phthalate \\
\hline 62 & 282 & Phytane \\
\hline 63 & 282 & $n-E i c o s a n e$ \\
\hline $64(\mathrm{a})$ & 286 & Di-i-butyrate, 2,2,4-trimethy?-1,3-pentanediol \\
\hline $65(a)$ & 290 & Manoyl oxide \\
\hline 66 (a) & 322 & 2-Butoxyethyl butyl phthalate \\
\hline 67 & 444 & Cyclohexasiloxane, dodecamethyl- \\
\hline $68(\mathrm{a}$ & 458 & Hexasiloxane, tetradecamethy?- \\
\hline
\end{tabular}

(a) Most abundant compounds.

Because building materials and household goods are a necessary consequence of twentieth century living, the only alternative is source control to mitigate excessive emissions. Studies have shown that emissions from building materials decrease greatly as the building ages (Miksh, Hollowell and Schmidt 1982; Berglund, Johansson and Lindvall 1982). An important option to mitigating excessive emissions is allowing new buildings to "dry out" until emission rates decline to acceptable levels. Other measures include 1) testing and labeling products, 2) selecting the least emissive or harmful materiais in building design, and 3) isolating unavoidable harmful products from occupants. Unfortunately, implementing some of these measures still requires considerable R\&D and the combined efforts of building designers and contractors, manufacturers, and government agencies (Hodgson et al. 1983). 
TABLE C.13. Compounds Emitted by Individual Building Construction and Interior Finish Material (Hodgson et a1. 1983)

\begin{tabular}{|c|c|c|}
\hline Sample to & Material & Identified Compounds $(a, b)$ \\
\hline $\mathrm{CS}-1$ & Particle board & $\begin{array}{l}19,25^{\star}, 30,42,53,56,58^{\star}, 59,60^{\star}, 62 ?, \\
63,65 ?^{\star},[+11 \text { unident. }]\end{array}$ \\
\hline $\mathrm{CS}-2$ & Plywood & $7,8^{\star}, 9,10^{\star}, 19^{\star}, 30^{\star}, 60,[+5$ unident. $]$ \\
\hline $\operatorname{CS}-3$ & Cedar & $\begin{array}{l}7,16^{\star}, 18,20,23,26^{\star}(2 \text { isomers }), 32, \\
42-1,[+2 \text { unident. }]\end{array}$ \\
\hline CI -1 & Fiberglass insulation & None detected \\
\hline $\mathrm{Cl}-2$ & Polyurethane foam & $3^{\star}, 4^{\star}, 5^{\star}, 57^{\star}, 60^{\star}, 67,[+13$ unident. $]$ \\
\hline IF $-1 \mathrm{~A}$ & Carpet padding & 64 \\
\hline IF $-1 B$ & Carpet padding & $\begin{array}{l}27,28 ?^{\star}, 37^{\star}, 40^{\star}, 43 ?, 53^{\star}, 56,57,60, \\
62,64^{\star},[+10 \text { unident. }]\end{array}$ \\
\hline IF -2 & Carpet & $\begin{array}{l}11,29,31^{\star}, 37^{\star}, 40^{\star}, 41,47,64^{\star}, \\
{[+10 \text { unident. }]}\end{array}$ \\
\hline IF -3 & Vinyl floor covering & $\begin{array}{l}15,27^{\star}, 36,40^{\star}, 51,56,64^{\star} \\
{[+7 \text { unident. }}\end{array}$ \\
\hline$I W-1$ & Vinyl floor covering & $\begin{array}{l}1,27,31^{\star}, 40,42,53^{\star}, 56,57,60^{\star}, 61^{\star}, \\
62,64^{\star},[+17 \text { unident. }]\end{array}$ \\
\hline$I H-2 a$ & Soft wall covering & $\begin{array}{l}6,12,13,14^{\star}, 21 ?, 22,24,28 ?, 31,34, \\
35,37^{\star}, 38 ?, 40^{\star}, 42,43,44,45 ?, 46,50, \\
52,53,54,55 ?, 56^{\star}, 57 ?, 58,60,64, \\
{[+31 \text { unident. }]}\end{array}$ \\
\hline$I W-2 B$ & Soft wall covering & $\begin{array}{l}1,28,31^{\star}, 35,37,40,42^{\star}, 49,53^{\star}, 56^{\star}, \\
57^{\star}, 58,60,63,64,[+13 \text { unident. }]\end{array}$ \\
\hline$I W-3$ & Wall panel & $\begin{array}{l}2,17,31^{\star}, 33,42,48,53^{\star}, 57,60^{\star}, 64^{\star}, \\
66^{\star}, 68^{\star},[+9 \text { unident. }]^{2}\end{array}$ \\
\hline IC $-1 \mathrm{~A}$ & Ceiling panel & $40^{\star}, 46^{\star}, 57,60,64^{\star},[+3$ unident. $]$ \\
\hline$I C-1 B$ & Ceiting panel & $38,51^{\star}, 53^{\star}, 56,60,[+8$ unident. $]$ \\
\hline
\end{tabular}

(a) Numbers correspond to the compounds listed in Table C.16.

(b) * - Most abundant compounds.

? - Identification uncertain.

I - Impurity. 
TABLE C.14. Compounds Emitted by Adhesives (Hodgson et a1. 1983)

Adhesive

S-1

$S-2$

$\mathrm{S}-3$

$S-6$

$5-7$

$W-1$

$W-2$

$W-3$
Chemical Identifications

Toluene; styrene

Low-molecular-weight alcohols; toluene

Toluene

n-Decane; n-undecane; $\mathrm{C}_{10^{-C}} \mathrm{C}_{11}$ branched alkanes $(9+$ compounds); $C_{10}$ cyclohexanes (4 compounds)

Methyl cyclopentane; cycrohexane; toluene

n-Octane; n-nonane; $\mathrm{C}_{8}-\mathrm{C}_{9}$ branched alkanes $(7+$ compounds); methyi cyclohexane; $C_{8}-\hat{C}_{9}$ cyclohexanes (10+ compounds)

Same compounds as $\mathrm{W}-1$

Toluene; $\underline{n}$-nonane; $\underline{n-d e c a n e ;} \underline{n}$-undecane; $C_{10}-c_{11}$ branched alkanes $(9+$ compounds $) ; c_{10}$ cyclohexane

\section{C.3.2 MICROORGANISMS}

As far back as 1546, it was speculated that infection and contagion might be caused by invisible organisms. Louis Pasteur, a French chemist, and Robert Koch, a German physician, established the relationship between microorganisms and disease by the late nineteenth century, and in 1910, C. V. Chapin wrote a chapter entitled "Infection by Air" in his book Sources and Modes of Infections (Chapin 1910).

\section{C.3.2.1 Airborne Microorganisms in Indoor Environments}

Hundreds of articies on microorganisms as airborne pollutants have appeared in the professional journals throughout the twentieth century. The National Research Council (1981b) has a reference list of 94 journal articles for indoor air contagion and 168 references to lung diseases and allergens dating back to one in 1916, "Human Sensitisation" appearing in the Journal of Immunology (Cooke and Vanderveer 1916).

Dr. F. Marc LaForce (1984), in a presentation at the 3rd international Conference on Indoor Air Quality and Climate, August 1984, summarized the historical advance of opinions and concepts. Generally accepted concepts have 
been arrived at largely from landmark incidents or outbreaks. He cites, for example, an article written for the Journal of Hygiene (1959) concerning a contagion incident in a tuberculosis ward in the 1950s. Another incident noted by Or. LaForce (1984) was the "Byrd outbreak," an unusual epidemic of tuberculosis aboard the submarine USS Richard S. Byrd in 1965-66. The outbreak was also inciuded in the "History and Epidemiology" segment of the Airborne Contagion Conference, December 1980, chaired by Ruth B. Kundsin and published in Annals of New York Acadeny of Sciences (Kundsin 1980).

The Epidemic Inteligence Service at the Communicable Disease Centers--now the Centers for Disease Control (CDC)--in Atlanta, Georgia, investigated such diseases as histoplasmosis, brucellosis and inhalation anthrax in the 1950 s and 1960s. The CDC's investigative study of the "Byrd outbreak" by their Environmental Health Services Division provided more information than had previously been available on the epidemiology of tuberculosis. The study also tested a generally held theory about one mode of transmission of tuberculosis--that infection was acquired from inhaling the tubercle bacillus in a droplet-nucleus which had been enitted into the atmosphere.

The significance of the "Byrd outbreak" comes from tracing the paths of infection and the role that a closed environment has on the spread of infection. The conclusion was that droplet nuclei from 2 to 10 microns were capable of being rapidiy and evenly dispersed throughout a closed environment by the recirculation ventilation system. Therefore, droplet nuclei may infect others who have little or no contact with an infected individual.

There is a possibility that anyone having the tubercle bacillus organisms in their puimonary secretions, whether that person is actively infected or is a "carrier" showing a positive tuberculin skin test with a normal chest $x-r a y$, may transmit the infection to susceptible individuals. It is also possible that disease outbreaks or contamination can occur in resuspended particles which are deposited on surfaces such as telephones and headsets, and later are disturbed or dislodged and become airborne. The pathogens once again are introduced into the indoor air and recirculated.

Airborne pathogens present in a ventilation system can be circulated and introduced to the indoor air and subsequently become a problem as an indoor air 
pollutant. The ventilation process can amplify transmission of the microorganism and consequently the contamination of air. Another specific example in more recent years was the outbreak of an unknown disease at the American Legion Convention in 1976. The ventilation system in the convention hotel in Philadelphia was implicated in the transmission and contamination the disease. The Centers of Disease Control in Atlanta carried out a massive epidemiologic investigation of the mysterious respiratory illness, which in some cases was fatal and in others produced an influenza-like illness. The organism causing the illness, Legionella pneumophila, was first identified in 1977. Several Legionella epidemics since have implicated ventilation systems as sources for or modes of transmitting the pollutant.

Airborne microorganisms have thus been recognized as a factor in indoor air quality. A broad collection of algae, bacteria, fungi, protozoa, mites (arachnids), and viruses presents a complex and varied set of pollutants. They are capable of provoking toxicity, infection, and allergenic responses, dermal conditions, and membraneous irritations which defy an automatic chemical assay or neutralization.

\section{C.3.2.2 Types of Microorganisms}

The types of pollutants identified and characterized below are relevant to residential indoor environments. These microorganisms are potential air pollutants that can affect human health under selected conditions.

- Algae

- simple plants that range in size fron microscopic cells to the macroscopic seaweed that people recognize

- species grown in presence of fresh water, salt water, soil, sand, hot water and even near-freezing habitats

- species primarily found in the resident enviconment proliferate on surfaces that are wet and often dark, such as on the wall of a toilet flush tank or in an air conditioning or humidity control system 
- Bacteria

- probably the most familiar type of microorganism known to the public for causing disease and illness, such as epidemics from salmonella, and streptococcal or staphylococcal infections

- innumerable species.

- Fungi

- plants devoid of chlorophyll, thus unable to synthesize their own food (not all are microorganisms)

- includes yeast and molds

- body parts and spores of these organisms can become airborne and invade the respiratory systern of occupant(s), causing $i 11$ ness or a dermatitis condition may result from a fungal growth on the body, i.e., on hands, in ears

- allergenic reactions have also been identified

- Mites

- minute four-legged insects of the arachnid class that inhabit the indoor environment, either in dust or on the dander flakes of pets and humans

- either source can becone airborne and thus be a pollutant as a respiratory agent, or as a dermal or mucus membrane irritant

- Protozoa

- one-celled animals

- the most familiar is the Amoeba, which is best known as a causative agent in an enteric illness known as "amoebic dysentery"

- some inhabit fresh water, some can be parasitic, and some live in mutualistic relationships 
- Viruses

- submicroscopic, intracellular entities growing in living cells of plants or animals

- generally require an electron microscope to be observed

- causative agent for diseases such as measles and influenza.

\section{C.3.2.3 Human Response to Microorganisms}

Some bacterial flora is normal in and on our bodies, as well as in the atmosphere, and does not cause 111 ness (is nonpathogenic) when in the "right place." This assemblage of microorganisms is seldom the same from one time to another, but it consists mostly of nonpathogenic organisms together with some potential pathogens (organisms capable of causing disease). This "normal flora" performs a valuable function for the body by keeping the numbers of potential pathogens at a low level by competing successfully with them for available nutrients. However, if unusuai circumstances develop within the body, the flora is disturbed so that the pathogen concentration increases to a level that initiates a clinical condition; that is, the pathogenic organisms produce disease symptoms in the host. Key contributors in a microorganism becoming an indoor air pollutant are the spatial and temporal conditions combined with receptance characteristics of occupants (immunity).

Two factors are important in the incidence of a microorganism becoming a pollutant in the indoor air environment. First, some organisms are more virulent than others; that is, they "more readily enter a host and produce a diseased condition." Second, "imrnunity," or the state of protection that includes atl the mechanisms that provide resistance to some specific disease, varies with individuals. There are two primary types of immunity: natural, or inborn, and acquired. Microorganisms become viable causative agents and thus airborne pollutants if a) circumstances develop where one or more microorganisms invade the body of a resident who is susceptible, or b) if immunity is reduced--or not even present--in an occupant who is exposed to a microorganism or simultaneously exposed to two or more of them. Allergenic responses, toxic reactions, infections, and dermal or mucous membrane irritations all are characterized by the individual response to exposure, or susceptibility, as well as 
the level of concentration of a pollutant. The time lapse and accumulated time of exposure, plus the location or space which harbors the pollutant, are the basic additional contributing factors.

Difficulties in sampling and getting definable, or even qualitative positive results have deterred progress in studying and anaiyzing pollutants. While indoor chemical pollution, along with ambient air quality, has received $\bar{c}$ great deal of public interest, efforts to fully understand, quantify and qualify the potential, indoor biological pollution have only recently been of broad interest. Harriet A. Burge, University of Michigan Medical School, states "The airborne bioflora is inherently complex and variable to a point that defies quantification" (Gammage and Kaye 1985). She observes that as many as four sampling modalities, for instance, would be necessary to accurately assess the measurable particles from a single room in a "clean" house because it may contain hundreds of different kinds of biological particles and technology does not exist to quantify all of them.

Eighty percent (80\%) of the average person's time is spent indoors but because people move from one place to another, not all of that time is necessarily spent in the same indoor environment. Because of this mobility patterr, people are not only exposed to both active and potential pollutants--chemical, respirable suspended particulates (RSP), and biological (microorganisms) pollutants--but often are exposed simultaneously to more than one. The effects isf simultaneous exposures are yet not really known.

\section{C.3.2.4 Host Areas for Microorganisms}

Some eptdemics of illness have no secondary spread of (infection) illness from one person to another. An example of this is a building outbreak of hypersensitivity pneumonitis (humidifier fever), where the source of the eticlogy was a bacillus species from the humidifier. of the 26 occupants, 7 (27\%) developed the pulmonary illness (Kreiss and Hodgson 1984). The indoor resideritial atmosphere has the same potential for harboring or hosting pollutants that cause both the building outbreak type of illness and the secondary spread of illness from person to person. 
Most severe indoor biological or microorganism pollution problems result from the growth of the offending organism on some surface within the structure. Therefore, these structures' designs should be examined for places where potential growth could be supported. The usual substrate or materials required for growth are water and a carbon source. A primary need is often a consistent source of moisture, and in some cases even a high reTative humidity is sufficient. Air circulating, heating and cooling systems are prime candidates for habitats where microorganisms may proliferate. Some sources for microorganism growth are listed in Table C.15. As shown in Table C.15, some systems or places in buildings that have been known to harbor or transmit pollutants are humidifiers, water in ventilation ducts, air filters, tap water, furnace humidifiers, heating and air conditioning systems, and conversely, dust sources, where humidity would not seem to be sufficient.

\section{C.3.2.5 Design Considerations}

Parts of the air system may contribute to the spread of airborne microorganisms, some of which may be pathogenic. Particularly critical to stopping the spread of airborne pathogen by a ventilation system are keeping the filters, ducts, and on-line or free-standing humidifiers or de-humidifiers clean and functioning efficiently. Any high-humidity site, such as the reservoir in an air-to-air heat exchanger or a furnace humidity pan, is a high-potential growth area for microorganisms. If microorganisms are introduced to indoor air in any manner and find compatible conditions for growth, they can proliferate and their concentration level will increase.

Humidity control is the single most contributing component in an indoor environment to discourage, remove or lessen the basic requirement for growth of most microorganisms (Buffaloe and Ferguson 1976; Pelczar and Reid 1972). Moisture is generated in residences by people, plants, and cooking. A family of 4 can generate as much as 5 gallons of moisture in a day (The Energy Business Association of Washington 1984). The new housing designs often do not specifically address humidity control. 
TABLE C.15. Building-Related Microorganism Outbreaks (Wa1sh, Dudney and Copenhaver 1984)

\begin{tabular}{|c|c|c|c|}
\hline Source & Etiology & Remedial Measures and Comments & Author \\
\hline Ceiling dust & $\begin{array}{l}\text { Amoebae, other } \\
\text { organisms }\end{array}$ & $\begin{array}{l}\text { Modified humidifier; water run } \\
\text { to waste; replaced ceiling; } \\
\text { discarded carpet; moved office } \\
\text { workers to new building; no } \\
\text { recurrence in } 24 \text { months }\end{array}$ & $\begin{array}{l}\text { Edwards } 1980 ; \\
\text { Edwards, } \\
\text { Griffiths and } \\
\text { Mullins } 1976\end{array}$ \\
\hline $\begin{array}{l}\text { Water in } \\
\text { ventilation } \\
\text { ductwork }\end{array}$ & $\begin{array}{l}\text { Thermophilic } \\
\text { act inomyces }\end{array}$ & Cleaned ductwork & $\begin{array}{l}\text { Hales and } \\
\text { Rubin } 1979\end{array}$ \\
\hline $\begin{array}{l}\text { Contaminated } \\
\text { air filters }\end{array}$ & Amoebae & $\begin{array}{l}\text { Closed school and dispersed } \\
\text { staff to other schools; in } \\
1 \text { mo. } 1 / 3 \text { were well, } 2 / 3 \\
\text { improved }\end{array}$ & Baxter 1982 \\
\hline Tap water & Undetermined & Removed humidifier & $\begin{array}{l}\text { Miller et al. } \\
1976\end{array}$ \\
\hline $\begin{array}{l}\text { Furnace } \\
\text { humidifier }\end{array}$ & $\begin{array}{l}\text { Micropolyspora } \\
\text { faeni }\end{array}$ & Removed furnace and humidifier & $\begin{array}{l}\text { Fink et al. } \\
1971 \text { (e) }\end{array}$ \\
\hline $\begin{array}{l}\text { Furnace } \\
\text { humidifier }\end{array}$ & $\begin{array}{l}\text { Thermophilic } \\
\text { actinomyces }\end{array}$ & Removed humidifier & $\begin{array}{l}\text { Sweet } \\
\text { et al. } 1971 \text { (a) }\end{array}$ \\
\hline $\begin{array}{l}\text { Heating or } \\
\text { air condi- } \\
\text { tioning } \\
\text { systems }\end{array}$ & $\begin{array}{l}\text { Thermophilic } \\
\text { actinomyces }\end{array}$ & $\begin{array}{l}\text { Moved from contaminated envi- } \\
\text { ronment or removed contami- } \\
\text { nated appliance }\end{array}$ & $\begin{array}{l}\text { Fink, et al. } \\
1976 \text { (a) }\end{array}$ \\
\hline $\begin{array}{l}\text { Humidifier, } \\
\text { air condi- } \\
\text { tioner, or } \\
\text { tap water } \\
\text { source }\end{array}$ & $\begin{array}{l}\text { Cephalosporium } \\
\text { in } 1 \text { case; un- } \\
\text { documented in } \\
5 \text { cases }\end{array}$ & $\begin{array}{l}\text { Removed humidifier or air } \\
\text { conditioner }\end{array}$ & $\begin{array}{l}\text { Patterson } \\
\text { et a7. } 1978(\dot{a})\end{array}$ \\
\hline
\end{tabular}

(a) Although these are documented from nonresidential buildings, they are systems common to the newly designed housing.

Other areas of a building are also important considerations for controlling microorganisms in residential indoor air. For example, microorganisms around the foundation of a house and in the intrawall space can be sources of indoor pollution. Concrete slab-type foundations are well suited to control the transfer of molds into the living area (Pfeiffer 1980). 
Each house has a breathing process--movement of air into a house, out of the house, and through the house walls--that occurs by means other than the usual heating and air-conditioning systems and window and door systems. The intrawalls can harbor dust that is allergenic, and a mold that is unseen can grow and disseminate spores into the living area via the passing air currents within the walls and vents, electrical outlets, etc. These may become a health hazard or an irritant to the hypersensitive resident.

\section{C.4 REFERENCES}

Abu-Jarad, F. and J. H. Fremlin. 1982. "The Activity of Radon Daughters in High-Rise Buildings and the Influence of Soil Emanation." In Indoor Air Pollution. Spengler, J. et al., eds., Proceedings of the International Symposium on Indoor Air Pollution, Health and Energy Conservation, October 13-16, 1981. Pergamon Press, New York, New York.

American Society of Heating, Refrigeration and Air-Conditioning Engineers (ASHRAE). 1985. Fundamentals Handbook. ASHRAE, Atlanta, Georgia.

American Society of Heating, Refrigeration and Air-Conditioning Engineers (ASHRAE). 1987. "Recommendations for Energy Conservation Standards and Guidelines for New Residential Buildings." In Volume 111: Introduction and Background to the Standard Development Effort. Specia1 Project 53, ASHRAE, Technical Evaluation Committee, Atlanta, Georgia.

Baxter, P. J. 1982. An Outbreak of Allergic-Type Symptoms Among Staff of an Elementary School: A Hazard of Moldy Air Filters? Special Studies Branch, Center for Environmental Health, Centers for Disease Control, Atlanta, Georgia.

Berglund, B., I. Johansson and T. Lindval1. 1982. "The Influence of Ventilation on Indoor/Outdoor Air Contaminants in an Office Building." Environmental International. 8:395-399.

Bonneville Power Administration (BPA). 1988. Final Environmental Impact Statement on New Energy-Efficient Homes Programs Assessing Indoor Air Quality 0ptions. DOE/EIS-0127F, BPA, Portland, Oregon.

Bruno, R. C. 1981. "Source of Indoor Radon in Homes." Paper presented at the International Symposium on Indoor Air Quality, October 13-16, 1981, Amherst, Massachusetts.

Buffaloe, N. D., and D. V. Ferguson. 1976. Microbiology. Houghton Mifflin Company, Boston, Massachusetts. 
Chapin, C. V. 1910. "Infection by Air." Ch. 7, In Sources and Modes of Infections, John Wiley and Sons, New York, New York.

Cole, et al. 1983. "Constituent Source Emission Rates Characterization of Three Gas-Fired Domestic Ranges." Presented at the 1983 APCA Annual Meeting, June 1983, IIT Research Institute and Institute of Gas Technology.

Cooke and Vanderveer, A., Jr. 1916. "Muman Sensitisation." Journal of Immunology. 1:201-305.

DeBortoli, M., et a1. 1984. "Integrating 'Real Life' Measurements of Organic Pollution in Indoor and Outdoor Air of Homes in Northern Italy." In Indoor Air Chemical Characterization and Personal Exposure, Vol. 4, pp. 21-26. Proceedings of the 3rd Internationat Conference on Indoor Air Quality and climate, Stockholm, Sweden.

Edwards, J. H. 1980. "Microbial and Immunological Investigations and Remedial Action After an Outbreak of Humidifier Fever." British Journal of Industrial Medicine. $37: 55$.

Edwards, J. H., J. A. Griffiths and J. Mullins. 1976. "Protozoa as Sources of Antigen in 'Humidifier Fever.'" Nature (London). 264:438.

Electric Power Research Institute. 1981. Comparison of Indoor and Outdoor Air Quality. Electric Power Research Institute, Palo Alto, California. EPRI EA-1733.

Electric Power Research Institute. 1985. Energy Use, Infiltration, and Indocr Air Quality in Tight, Well-Insulated Residences. Electric Research Institute, Palo Alto, California. EPRI EA/EM-4117.

Eschback, 0. W., ed. 1956. Handbook of Engineering Fundamentals. John Wiles \& Sons, New York, New York.

Fink, J. N., et al. 1971. "Interstitial Pneumonitis Due to Hypersensitivity to an Organism Contaminating a Heating System." Ann. Intern. Med. 74:80.

Fink, J. N., et al. 1976. "Interstitial Lung Disease Due to Contamination o* Forced Air Systems." Ann. Intern. Med. 84:406.

"Formaldehyde--Assessing the Risk." Environmental Science and Technology. 1984. 8(7):216A-221A.

Gammage, R. B., and S. Kaye (eds.). 1985. Indoor Air and Human Health. Lewis Publishers, Chelsea, Michigan.

Gammage, R. B., et a1. 1984. "Residential Measurements of High Volatility Organics and Their Sources." In Indoor Air Chemical Characterization and Personal Exposure. Vol. 4, pp. 157-162, Proceedings of the 3rd Internationa? Conference on Indoor Air quality and Climate, Stockholm, Sweden. 
Girman, J. R., et al. 1981. Pollutant Emissions and Source Strengths frorn Indoor Combustion Appliances and Smoking. Lawrence Berkeley Laboratory, University of California, Berkeley, Catifornia.

Girman, J. R., et al. 1982. "Pollutant Emission Rates from Indoor Combustion Appliances and Sidestream Cigarette Smoke." Environmental International. 8:213-222.

Golden, J., et a1. 1980. Environmental Impact Data Book. Ann Arbor Science Publishers, Inc., Ann Arbor, Michigan.

Gosselin, R. E., et al. 1984. Clinical Toxicology of Commercial Products. 5 th edition, William and Wilkens, Baltimore, Maryland.

Grot, R. A., and R. E. Clark. 1979. Air Leakage Characteristics and Weatherization Techniques For Low Income Housing. Proceedings of the ASHRAEDOE Conference on the Thermal Performance of the Exterior Envelope of Buildings, ASHRAE, Atlanta, Georgia.

Grimsrud, D. T., M. H. Sherman and R. C. Sondregger. 1982. Calculating Infiltration: Implications for a Construction Quality Standard. Proceedings of the ASHRAE-DOE Conference on the Thermal Performance of the Exterior Envelope of Buildings, II, Atlanta, Georgia.

Gupta, K. C., A. G. Ulsamer and P. W. Preuss. 1982. "Formaldehyde in Indoor Air: Sources and Toxicity." Environmental International. 8:349-358.

Hartwe11, T. D., et a1. 1984. "Comparative Statistical Analysis for Volatile Hydrocarbons in Indoor and Outdoor Air." In Indoor Air Chemical Characterization and Personal Exposure, Vol 4, pp. 57-61. Proceedings of the 3rd International Conference on Indoor Air Quality and Climate, Stockholm, Sweden, August 20-24, 1984.

Hales, C. A. and R. H. Rubin. 1979. "Case Records of the Massachusetts General Hospital." Case 47-1979. English Journal of Medicine. 301:1168.

Hodgson, A. T., et a1. 1983. Emissions of Volatile Organic Compounds from Architectural Materials with Indoor Apptications. LBL-17130, Available from the National Technical Information Service, Springfield, Virginia.

Hollowell, C. R., et al. 1981. Building Ventilation and Indoor Air Quality. 1980 Annual Report, LBL-11985, Lawrence Berkeley Laboratory, University of California, Berkeley, California.

Kreiss, K., and M. J. Hodgson. 1984. "Building-Associated Epidemics." In Indoor Air Quality. Lewis Publishers, Inc., Chelsea, Michigan.

Kundsin, R. B. 1980. Airborne Contagion. Vol. 353 of the Annals of the New York Academy of Sciences. New York, New York.

LaForce, M. F. 1984. "Airborne Infections and Modern Building Technology." 
Lang, N. A. (ed.). 1956. Handbook of Chemistry. Handbook Publishers, Inc., Sundusky, Ohio.

Lebret et al. 1984. "Volatile Hydrocarbons in Dutch Homes." In Indoor Air Chemical Characterization and Personal Exposure. Vol. 4, pp. 169-174. Proceedings of the 3rd International Conference on Indoor Air Quality and Climate, August 20-24, 1984, Stockholm, Sweden.

Meyer, B. 1983. Indoor Air Quality. Addison-Wesley Publishing Company, Inc., Reading, Massachusetts.

Miksch, R. R., C. D. Hollowell and H. E. Schmidt. 1982. "Trace Organic Contaminants in 0ffice Spaces." Environmental International. 8:129-137.

Miller, M. M., et al. 1976. "Chronic Hypersensitivity Lung Disease with Recurrent Episodes of Hypersensitivity Pneumonitis Due to a Contaminated Central Humidifier." Clin. Allergy. 6:451.

Molhave, L. 1982. "Indoor Air Pollution Due to Organic Gases and Vapors of Soivents in Building Materials." Environmental International. 8:117-127.

Moschandreas, D. J. and J. Zabransky, Jr. 1981. "The Effects of Woodburning on Indoor Residential Air Quality." Environmental International, 4:463-468.

National Research Council. 1981a. Indoor Pollutants. National Academy Press, Washington, D.C.

National Research Council. 1981b. Formaldehyde and Other Aldehydes. National Academy Press, Washington, D.C.

Nitschke, I. A., G. W Traynor, J. B. Wadach, M. E. Clarkin, and W. A. Clarke. 1985. Indoor Air Quality, Infiltration and Ventilation in Residentia1 Buildings. W. S. Fleming and Associates, Syracuse, New York.

Patterson, R., et a1. 1978. "Antibody Activity in Sera of Patients with Humidifier Disease." J. Allergy Clin. Immunol. 62:103.

Peiczar, M. J., Jr., and R. D. Reid. 1972. Microbiology. McGraw-Hill Book Company, New York, New York.

Pfeiffer, G. 0., ed. 1980. The Household Environment and Chronic Illness. Charles C. Thomas, Springfield, Illinois.

Sachs, H. M., T. L. Hernandez and J. W. Ring. 1982. "Regional Geology and Radon Variability in Buildings." Environmental International. 8:97-104.

Soldat, J. K. 1961. Some Radioactive Materials Measured in Various Waters in the United States, A Literature Search. General Electric, Richland, Washington.

Sweet, L. C., et al. 1971. "Hypersensitivity Pneumonitis Related to a Home Furnace Humidifier." J. Allergy Clin. Immunol. 48:171. 
The Energy Business Association of Washington. 1984. Energy Efficient Home Construction Techniques Manual. Available from Washington State Energy office, olympia, Washington.

U.S. Environmental Protection Agency (EPA). 1978. Indoor Air Pollution in the Residential Environment. U.S. Environmental Protection Agency, Washington, D.C.

U.S. Environmental Protection Agency (EPA). 1979. A Study of Radon-222 Released from Water During Typical Household Activities. EPA/ORP-EERF-79-1, Environmental Protection Agency, Washington, D.C.

Wallace, L., et al. 1984. "Analysis of Exhaled Breath of 355 Urban Residents for Volatile Organic Compounds." In Indoor Air Chemical Characterization and Personal Exposure. Vol. 4, pp. 15-20. Proceedings of the 3rd International Conference on Indoor Air Quality and Climate, Stockholm, Sweden, August $20-24,1984$.

Walsh, P. J., C. S. Dudney and F. D. Copenhaver. 1984. Indoor Air Quality. CRC Press, Boca Raton, Florida.

Wishnok, J. S. June 1984. "The Mutagens that Cooking Produces." Chem. Tech. pp. 348-352. 


\section{APPENDIX D}

HEALTH IMPACTS OF SELECTED AIR POLLUTANTS 
APPENDIX D

\section{HEALTH IMPACTS OF SELECTED AIR POLLUTANTS}

In this appendix the health impacts of the six residential indoor air pollutants that have been the most thoroughiy studied for their impacts on human health are discussed: particulate matter, carbon dioxide, carbon monoxide, nitrogen dioxide, formaldehyde, and radon.

\section{D.1. PARTICULATE MATTER}

This section discusses the population groups sensitive to particulate matter, the short-term and long-term effects of the pollutant, and the recommended outdoor standard for particulate matter.

\section{D.1.1 Sensitive Population Groups}

One of the major considerations for setting air quality standards is the protection of sensitive population groups, who are most likely to be affected by indoor air pollutants. Table D.1 summarizes various sensitive population subgroups, and also provides the rationale and supporting evidence on health effects of particulate matter. Studies based on lower levels of community exposures and other sources suggest that some segments of the population may be at higher-than-average risk. These include children, asthmatics, smokers, obligatory mouth breathers and persons with pneumoconiosis or influenza.

Because much individual variation exists among subgroups, at any given level of particulate matter, children may note only symptomatic irritation, while members of other subgroups or others in the subgroup may suffer deterioration of respiratory function.

Results from the U.S. National Health Interview Survey for 1970 indicate that chronic respiratory disease comprises $10 \%$ of all conditions causing disability of one week or more [U.S. Department of Health, Education and Welfare (DHEW) 1973]. In 1970, there were about 6.5 million chronic bronchitics, 6.0 million asthmatics, 1.3 mitlion individuals with emphysema and about 
TABLE 0.1. Sensitive Poputation Subgroups to ParticuTates (EPA 1982)

\begin{tabular}{|c|c|c|c|}
\hline Subgroup & Population Estimates & Ratlonale (or Criteria) & Doseryational/Associatians Supporting Increased Sensitirlty \\
\hline \multirow{2}{*}{$\begin{array}{l}\text { Indlviduals wleh } \\
\text { chronic } \\
\text { ohstructive } \\
\text { gulmonary disedses } \\
\text {. Brcochlets } \\
\text { Oronchlectasis } \\
\text {. Emphysems }\end{array}$} & \multirow[t]{2}{*}{$7,800,0000\{00, E, .9973\}$} & $\begin{array}{l}\text { - Mucus hypersecretion and blocked } \\
\text { almusys may predispose individuols to } \\
\text { bronchospasa }\end{array}$ & \multirow{2}{*}{ 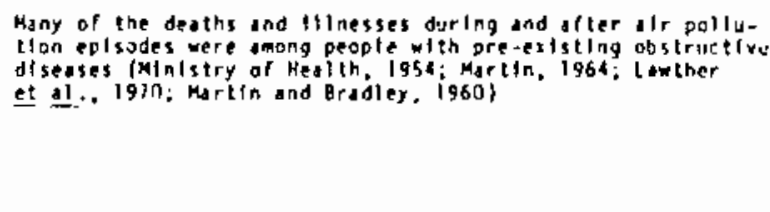 } \\
\hline & & 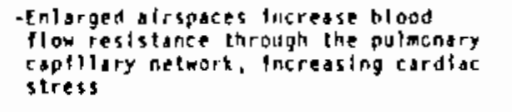 & \\
\hline $\begin{array}{l}\text { individuals with } \\
\text { cardloyoscular } \\
\text { disease }\end{array}$ & $16,100,000(0 \times,, 1980)$ & $\begin{array}{l}\text {-Enhanced sensitlutty to difficulties } \\
\text { in oreathing }\end{array}$ & 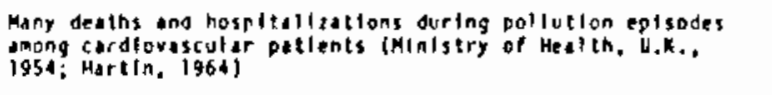 \\
\hline $\begin{array}{l}\text { indirldusis with } \\
\text { Influenza }\end{array}$ & Unk nown & 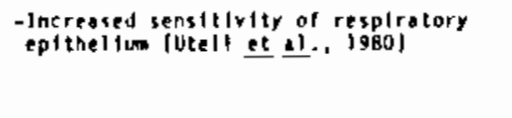 & 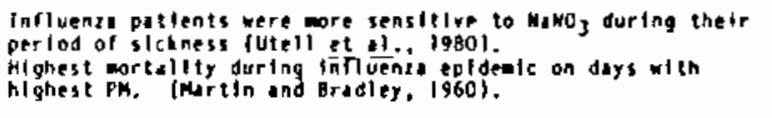 \\
\hline Astinatics & $6,000,000(01161,19 / 3)$ & 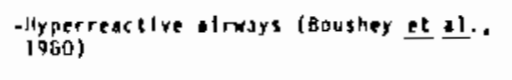 & 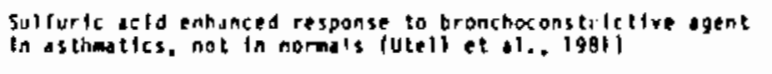 \\
\hline Inderly & $\begin{array}{l}24,6+8,000 \\
>65 \text { years old } \\
(400,1980)\end{array}$ & $\begin{array}{l}\text {-Reduced lung elastlcity icotes, (9/9) } \\
\text {-Imunalogicilly deficient }\end{array}$ & 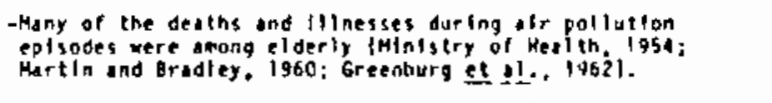 \\
\hline \multirow[t]{3}{*}{ Chlldren } & \multirow[t]{3}{*}{ 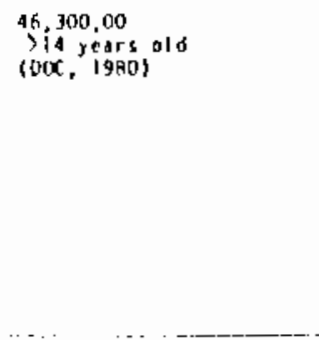 } & 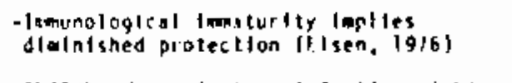 & 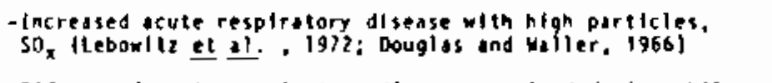 \\
\hline & & 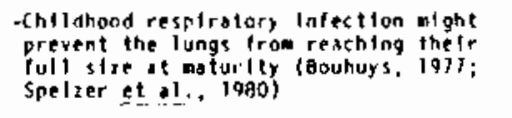 & \multirow[t]{2}{*}{ 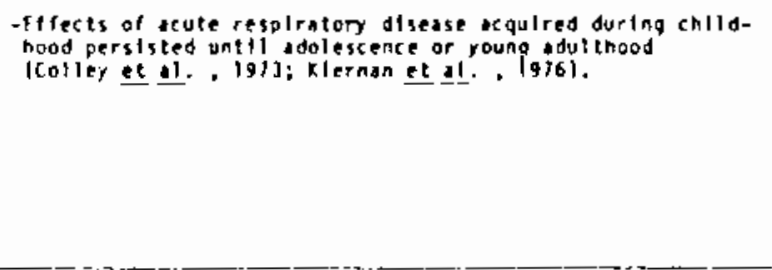 } \\
\hline & & 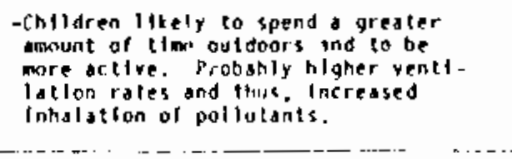 & \\
\hline \multirow[t]{3}{*}{ Smukers } & $50.000,000\{0 \mathrm{~W} \mid \mathrm{W}, 107\}$ & 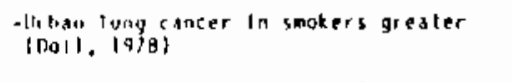 & \multirow[t]{3}{*}{ 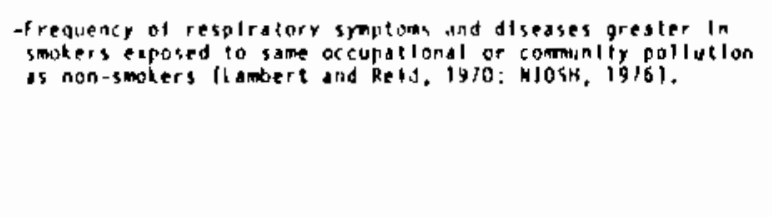 } \\
\hline & & 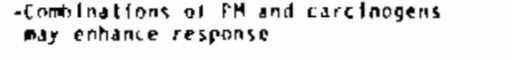 & \\
\hline & & 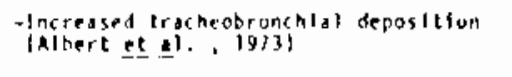 & \\
\hline $\begin{array}{l}\text { Kinth or aronasal } \\
\text { biesthers }\end{array}$ & 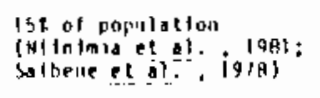 & $\begin{array}{l}\text { - Imeased particle penetration } \\
((n, p, 19-20)\end{array}$ & \\
\hline
\end{tabular}


10 million adults with heart disease severe enough to limit activity (DHEW 1973). These are rough estimates since some surveys have reported higher figures depending on age, sex, and the definition of disease that is used. Limited physiologica? studies suggest that about $15 \%$ of the population are habitual mouth or oronasal breathers (Saibene et al. 1978; Niinimaa et al. 1981). (Anyone may temporarily switch to mouth breathing during exercise, illness, or conversation.)

Although there are about 50 million smokers, the number of people at a higher-than-expected risk because of smoking may also include children living with smokers, and ex-smokers (DHEW 1977). In addition, some workers who are occupationally exposed to dusts might become more susceptible to residentia? particulate pollution, even if they are not classified as having respiratory disease. The more sensitive individuals, however, often do not remain in such environments (Morgan 1978).

\section{D.1.2 Short-Term Impacts}

Based on evaluation of epidemiological studies on particulate matter, the Environmental Protection Agency (EPA) (1982) presented its assessment of concentration levels at which short-term health effects might be expected (Table D.2). The lowest pollutant levels of interest in the short-term studies

\section{TABLE D.2. Staff Assessment of Short-Term Epidemiological Studies (EPA 1982)}

\begin{tabular}{|c|c|c|c|c|}
\hline \multirow[b]{2}{*}{$\begin{array}{l}\text { Effects/ } \\
\text { Study }\end{array}$} & \multicolumn{3}{|c|}{ Measured British Smoke Leveis $\left(\mu \mathrm{g} / \mathrm{m}^{3}\right)$} & $\begin{array}{l}\text { Equivalent } \operatorname{Tp}(\mathrm{a}) \\
\text { Levels }\left(\mathrm{\mu g} / \mathrm{m}^{3}\right) \\
\end{array}$ \\
\hline & $\begin{array}{l}\text { Daily Mortality } \\
\text { in London }(b)\end{array}$ & $\begin{array}{l}\text { Aggravation of } \\
\text { Bronchitis }(c)\end{array}$ & $\begin{array}{l}\text { Combined } \\
\text { Range } \\
\end{array}$ & Combined Range ${ }^{(d)}$ \\
\hline $\begin{array}{l}\text { Effects } \\
\text { Likely }\end{array}$ & $500-1000$ & $250^{\star}-500^{\star}$ & $250-500$ & $360-600$ \\
\hline $\begin{array}{l}\text { Effects } \\
\text { Possible }\end{array}$ & $150^{\star}-500$ & $<250^{*}$ & $150-250$ & $150-350$ \\
\hline
\end{tabular}

* Indicates leveis used for upper or lower bound of range.

(a) TP: thoracic particles less than a nominal $10 \mu \mathrm{m}$.

(b) Martin and Bradley 1960; Ware et al. 1981; Mazumdar, Schimmel and Higgins 1981 .

(c) Lawther, Waller and Henderson 1970.

(d) Boundary assumptions for estimating TP levels from British smoke readings detailed in EPA (1982). 
were 150 to $500 \mu \mathrm{g} / \mathrm{m}^{3}$ (British smoke) and 150 to $500 \mu \mathrm{g} / \mathrm{m}^{3}\left(\mathrm{SO}_{2}\right)$ (based on mortality studies), and $250 \mu \mathrm{g} / \mathrm{m}^{3}$ (British smoke) and $500 \mu \mathrm{g} / \mathrm{m}^{3} \mathrm{SO}_{2}$ (based on the bronchitic studies). On particles EPA staff made the conservative assumption that similar responses might have occurred without substantial amounts of $\mathrm{SO}_{2}$ present (EPA 1982).

\section{D.1.3 Long-Term Impacts}

Table 0.3 is an EPA staff assessment of the levels of interest derived from the most usefu? long-term epidemiological studies (EPA 1982). Based on their assessment, levels of interest for effects measured in these studies are as follows: 1) decreased lung function and increased acute respiratory disease in children may occur at levels below $230 \mu \mathrm{g} / \mathrm{m}^{3}$ British smoke (Lunn, Knowelde? and Handyside 1967); 2) decreased lung function in adults may occur at TSP levels as low as 140 to $180 \mu \mathrm{g} / \pi^{3}$ (Bouhuys, Beck and Schoenberg 1978); and 3) some risk of increased respiratory disease and/or symptoms in adults may exist at levels of 110 to $180 \mu \mathrm{g} / \mathrm{m}^{3}$ TSP (Bouhuys, Beck and Schoenberg 1978; Ferris et aT. 1973).

\subsubsection{Recommended Outdoor Standard for Particulate Matter}

Selecting a level with an adequate margin of safety for a standard for particulate matter will involve several uncertainties in addition to those involved in making judgments on health risks associated with other pollutants such as $\mathrm{CO}$ and $\mathrm{SO}_{2}$. Epidemiological studies are generally subject to severa] inherent difficulties involving confounding variables and somewhat limited sensitivity. Most studies have used British smoke [a pseudo mass indicator related to small particle (<4.5 um darkness)] or total suspended particulates (TSP) $(<25-45, \mathrm{~m})$ as particle indicators.

The current U.S. standard has been based on TSP levels measured by highvolume sampler. However, this TSP standard might have directed control efforts towards particles of lower risk to health because it included larger particles which can dominate the measured mass concentration and which are deposited oniy in the extrathoracic region. Thus, the EPA staff has recommended a new particle indicator representing particles capable of penetrating the thoracic regions, defined as the particle size less than a nominal 10 $\mu[\mathrm{m}$ (EPA 1982). 
TABLE D.3. Staff Assessment of Long-Term Epidemiological Studies (EPA 1982)

\begin{tabular}{|c|c|c|c|c|c|}
\hline & $\begin{array}{l}\text { Heasured BS } \\
\left.\text { Levels (as } \mu \mathrm{g} / \mathrm{m}^{3}\right)\end{array}$ & Hea & ured TSP Levels & & $\begin{array}{l}\text { Equivalent } \mathrm{Tg} \\
\text { Levels }(\mu \mathrm{g} / \mathrm{m})\end{array}$ \\
\hline Study/Effect & $\begin{array}{l}\text { Increased Resplratory } \\
\text { Disease, Reduced Lung } \\
\text { Function in Children }\end{array}$ & $\begin{array}{l}\text { Increased Respiratory } \\
\text { Disease Symptoms, } \\
\text { Small Reduction in Lung } \\
\text { Function in Adults? }\end{array}$ & $\begin{array}{l}\text { Increased Respiratgry } \\
\text { Symptoms In Adults }\end{array}$ & $\begin{array}{l}\text { Comb ined } \\
\text { Range }\end{array}$ & $\begin{array}{l}\text { Combiged } \\
\text { Range }\end{array}$ \\
\hline Effects Lfkely & $230-30085$ & $180^{\star}$ & - & $\geq 180$ & $90-110$ \\
\hline Effects Possible & $<230$ BS & $130-180^{\star}$ & $60-150\left(110^{*}\right)$ & $110-180$ & 55.110 \\
\hline $\begin{array}{l}\text { No Significant } \\
\text { Effects Hoted }\end{array}$ & $-\infty$ & $80^{\star}-130$ & -- & $B 0-110$ & $40-55$ \\
\hline
\end{tabular}

*Indicates levels used for upper or lower bound of range.

${ }^{1}$ Study conducted in Sheffield, England (Lunn et al.. 1967).

${ }^{2}$ Studies conducted in Verlin, WH (Ferris et al.. 1973, 1976).

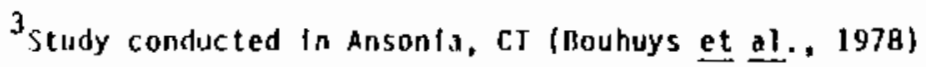

${ }^{4}$ Converstion assumes range of TP/TSP of 0.5 to 0.6 . 
As a resuit of the EPA staff risk assessment (EPA 1982) of epidemiological studies, the following ambient air quality standards for thoracic particles (TP) have been recommended:

$$
\begin{array}{lr}
\text { 24-hour standard } & 150-350 \mu \mathrm{g} / \mathrm{m}^{3} \\
\text { annual standard } & 55-110 \mu \mathrm{g} / \mathrm{m}^{3}
\end{array}
$$

The upper end of the above range may contain no identifiable margin of safety; however, neither the studies summarized in TabTes D.1 and D.2 nor the: effects in controlled human studies provide scientific support for health risks of consequences below the lower end of the above range.

\section{D.2 CARBON MONOXIDE}

On April 30, 1971, the Environmental Protection Agency promulgated national ambient air quality standards (NAAQS) for $C 0$ at leveis of 9 parts per million (ppm), 8-hour average, and 35 ppri, 1-hour average, neither to be exceeded more than once per year. In July 1984, an EPA staff paper was published describing their evaluation of the key studies and scientific information on $C O$ and their recommendation on the possible revision of the current primary and secondary NAAQS for CO. This section sumarizes that EPA Staff paper (EPA 1984).

\section{D.2.1 Sensitive Population Groups}

Tabie 0.4 briefly summarizes the rationale for the judgments that these groups are more likely to be affected by low-level co exposures and presents poputation estimates for each group. For most of the groups listed in Table 0.4, there is little specific experimental evidence to clearly demonstrate that they are at increased risk for co-induced health effects. Howeven, individuals with pre-existing illnesses or physiological conditions which limit oxygen absorption into blood or its transport to body tissues would be expected to be more susceptible to the hypoxic (i.e., oxygen starvation) effects of co.

In the EPA staff's judgment, the available health effects' evidence stil suggests that persons with angina, peripheral vascular disease, and other types 
TABLE D.4. Summary of Potentially Sensitive Population Groups(a) (EPA 1984)

\begin{tabular}{|c|c|c|c|c|}
\hline Group & Rationale & $\begin{array}{l}\text { Population } \\
\text { Estimates }\end{array}$ & $\begin{array}{l}\text { Percent of } \\
\text { Population }\end{array}$ & Reference \\
\hline $\begin{array}{l}\text { Coronary Heart } \\
\text { Disease }\end{array}$ & $\begin{array}{l}\text { Anderson et ol. }\{1973 \text { suggests } \\
\text { reduced time until onset of } \\
\text { exercise }+1 \text { induced angind in } \\
2.9-4.51 \text { collo range }\end{array}$ & $\begin{array}{l}7.9 \text { nil fon } \\
(\text { in } 1979)\end{array}$ & $\begin{array}{l}\text { S.0 lof the adult } \\
\text { populationi }\end{array}$ & OKEY, 1975 \\
\hline - Angla Pectorls & & $\begin{array}{l}6.5 \mathrm{~m} 11110 \mathrm{on} \\
\text { (in } 1979)\end{array}$ & $\begin{array}{l}\text { 4.0 for the aduit } \\
\text { populationi }\end{array}$ & \\
\hline $\begin{array}{l}\text { Chronlc obstructive } \\
\text { Pulmonary Diseases } \\
\text { - Bronchitis } \\
\text { : Emphysena } \\
\text { Asthma }\end{array}$ & $\begin{array}{l}\text { Reduced reserve capacletes for } \\
\text { dealing with cardiovascular } \\
\text { stresses and already reduced } \\
\text { oxygen supply in blood likely } \\
\text { to hasten onset of health } \\
\text { effects assoclated wilth co- } \\
\text { finduced hypoxla. }\end{array}$ & $\begin{array}{l}6.5 \text { milition }(1970) \\
1.5 \text { milition }(1970) \\
6.0 \text { uilition }(1970)\end{array}$ & $\begin{array}{l}3.3 \\
0.7 \\
3.0\end{array}$ & DHEX. 1973 \\
\hline $\begin{array}{l}\text { Fetuses and } \\
\text { roung Infonts }\end{array}$ & $\begin{array}{l}\text { Several animal studfes (longo, } \\
\text { ig7l) repart deleterlous effects } \\
\text { in of foring (e.g.e reduced } \\
\text { birth welght. Increased newborn } \\
\text { mortality ond lower behavforal } \\
\text { activity ievels). }\end{array}$ & $\begin{array}{l}\text { J.I million live } \\
\text { births/year (1975) }\end{array}$ & & DHEY, 1978 \\
\hline $\begin{array}{l}\text { Perniclous and } \\
\text { Deflctency Anemias }\end{array}$ & $\begin{array}{l}\text { Oxygen-carrying capacity due } \\
\text { deformed red blood cells is } \\
\text { already reduced increasing inkeli- } \\
\text { hood of co-induced hypoxta effects } \\
\text { at lower co exposure levels than } \\
\text { for non-anealc individuals. }\end{array}$ & ${ }^{(15}$ mflulion & 0.07 & \\
\hline $\begin{array}{l}\text { Peripheral } \\
\text { Vascular olsease }\end{array}$ & $\begin{array}{l}\text { Aronow et al. }(1974) \text { suggests } \\
\text { reduced time until onset of } \\
\text { exercise-1nduced leg pain after } \\
\text { exposure to co. }\end{array}$ & $\begin{array}{l}0.75 \text { m11110n } \\
\text { (in 1979) }\end{array}$ & 0.3 & DHEL, 1914 \\
\hline Elderly & $\begin{array}{l}\text { co exposures moy increase } \\
\text { susceptibitity of elderly } \\
\text { lndfylduals to other } \\
\text { cardiovascular stresses due } \\
\text { to already reduced reserve } \\
\text { capacitles to maintain } \\
\text { adequate oxygen supply to } \\
\text { body tissues. }\end{array}$ & $\begin{array}{l}24.7 \text { millition } \\
65 \text { years old }\end{array}$ & & OCC. 1980 \\
\hline
\end{tabular}

all subgroups listed are not necessarily sensitive to co exposure at low levels. 
of cardiovascular disease are the group at greatest risk from low-level, ambient exposures to $\mathrm{CO}$. This judgment is based principaliy on the Andersor. et al. (1973) study, which indicates that individuals with angina may be affected at carboxyhemoglobin (COHb) leveis ranging from $2.9 \%$ to $4.5 \%$. In addition, while there is less confidence in the results reported in Aronow et a]. (1974), that study still suggests that individuals with peripheral vascular disease may be at risk from ambient exposures to $\mathrm{CO}$.

\subsubsection{Reported Effects, Levels of Effects and Severity of Effects}

Table D.5 sumarizes key clinical studies reporting human health effects associated with low-level exposures to $\mathrm{CO}$. This table is based on evidence discussed in the 1979 Criteria Document (EPA 1979) and in the Draft Addendum(a) but excludes a series of studies by Dr. Aronow (1974) because of problems that substantially limit the validity and usefulness of the Aronow studies (Horvath et ai. 1983).

The lowest observed co exposure levels that produce human health effects have been reported in studies involving individuals suffering from chronic angina pectoris. Angina pectoris, commonty referred to as angina, is a symptom of cardiovascular stress in which mild exercise or excitement can produce pressure or pain in the chest because of insufficient oxygenation of heart muscli.

\subsubsection{Relationship Between CO Exposure and COHb Levels}

The health effect studies discussed above report the effects observed a1: varying COHb levels. To set ambient CO standards based on these studies, the ambient concentrations of $\mathrm{CO}$ that are likely to result in $\mathrm{COHb}$ levels at or near those observed in the studies must be estimated. A model known as the Coburn equation (Coburn, Forster and Kane 1965) has been developed to estimate COHb levels resulting from $\mathrm{CO}$ concentrations as a function of time and various physiological factors (e.g., blood volume, endogenous co production rate).

(a) EPA. 1983 (draft). "Revised Evaluation of Health Effects Associated with Carbon Monoxide Exposure: An Addendum to the 1979 EPA Air Quality Criteria Document for Carbon Monoxide." Research Triangle Park, North Carolina. 
TABLE 0.5. Lowest Observed Effect Levels for Human Health Effects Associated with Low-Level Carbon Monoxide Exposure (EPA 1984)

\begin{tabular}{|c|c|c|}
\hline Effects & $\begin{array}{l}\text { Cofb concentration } \\
\text { (Percent) }\end{array}$ & References \\
\hline $\begin{array}{l}\text { Statisticaliy significant decreased } \\
(-3-7 \Delta) \text { work time to exhaustion } \\
\text { in exercising young healthy men }\end{array}$ & $2.3-4.3$ & $\begin{array}{l}\text { Horvath et a?. } 1975 \\
\text { Drinkwater et al , } 1974 \\
\text { Raven et al., } 1974\end{array}$ \\
\hline $\begin{array}{l}\text { Statistically significant decreased } \\
\text { exercise capacity (i.e. shortened } \\
\text { duratian of exercise before onset of } \\
\text { pain) in patients with angina pectoris } \\
\text { and increased duration of angina attacks }\end{array}$ & $2.9-4.5$ & Anderson et $31 \ldots 1973$ \\
\hline $\begin{array}{l}\text { Statisticaliy significant decreased } \\
\text { maximal oxygen consumption and } \\
\text { exercise time during strenuous } \\
\text { exercise in young healthy men }\end{array}$ & $5 \cdot 5.5$ & $\begin{array}{l}\text { Klein et al., } 1980 \\
\text { Stewart et al., } 1978 \\
\text { Weiser et al., } 1980\end{array}$ \\
\hline $\begin{array}{l}\text { No statistically significant } \\
\text { vigilance decrements after } \\
\text { exposure to con }\end{array}$ & Below 5 & $\begin{array}{l}\text { Haider et al., } 1976 \\
\text { Winneke, } 1973 \\
\text { Christensen et al } 1977 \\
\text { Benignus et a1. } 1977 \\
\text { Putz et al., } 1976\end{array}$ \\
\hline $\begin{array}{l}\text { Statistically significant impaiment } \\
\text { of vigilance tasks in healthy } \\
\text { experimental subjects }\end{array}$ & $5-7.6$ & $\begin{array}{l}\text { Horvath et al., } 1971 \\
\text { Groll-knapp et al., } 1972 \\
\text { Fodor and Hinneke, } 1972 \\
\text { Putz et al., } 1976\end{array}$ \\
\hline $\begin{array}{l}\text { Statistically significant diminution } \\
\text { of visual perception, manual dexterity, } \\
\text { ability to learn, or performance in } \\
\text { complex sensorimotor tasks } \\
\text { (such as driving) }\end{array}$ & $5-17$ & 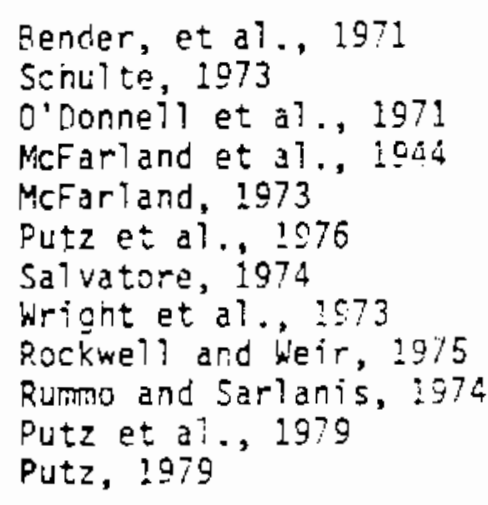 \\
\hline $\begin{array}{l}\text { Statistically significant } \\
\text { decreased maximal oxygen } \\
\text { consumption during strenuous } \\
\text { exercise in young heal thy men }\end{array}$ & 720 & $\begin{array}{l}\text { Ekbiom and Huot, } 1972 \\
\text { Pirnay et a1.: } 1979 \\
\text { Vogel and Gleser. } 1972\end{array}$ \\
\hline
\end{tabular}

aThe physiologic nom (i.e., Cohb levels resulting from the normal catabolism of hemoglobin and other heme-containing materiais) has been estimated to be in the range of 0.3 to 0.7 percent (Coburn et al., 1263). 
Table D.6 presents baseline estimates (a typical set of physiological parameters was used) of $\mathrm{COHb}$ levels expected to be reached by nonsmokers exposed to various constant concentrations of $\mathrm{CO}$ for ejther 1 or 8 hours, based on the Coburn model. The estimates are based on variations in physiological parameters upon exposure to different patterns of $\mathrm{CO}$ Tevels which just meet $a$ given $\mathrm{CO}$ standard. The estimates given in Table D.7 and others contained in a sensitivity analysis report of the Coburn Model (Biller and Richmond 1982) are based on the assumption that the entire adult population is exposed to co leveis just meeting a given standard.

The impact of fluctuating air quality levels on COHb uptake can be roughiy estimated by comparing the result of a constant 9 ppm exposure for 8 hours (1.4\% coHb from Table D.6) with a "typical" (50th percentile) adult exposed to several different air quality patterns that result in the same maximum 8-hour dose (i.e., 9 ppm, 8-hour average). The various patterns examined in the Sensitivity Analysis indicate that CoHb levels ranging from $1.4 \%$ to $1.9 \%$ (frcm Table 0.7) can be reached for the "typical" adult exposed to air quality reaching a $9 \mathrm{ppm}$, 8-hour average (Bilier and Richmond 1982). A similar comparison of the results for air quality with a $12 \mathrm{ppm}, 8$-hour average peak exposure indicates that the impact of fluctuating $\mathrm{CO}$ levels can increase the peak $\mathrm{COHb}$ value by up to $0.5 \%$ to $0.6 \%$ COHb.

The Sensitivity Analysis results in Table 0.7 also iliustrate the effect of using distributions for each physiological parameter rather than just a representative set of physiological parameters in applying the Coburn mode?. For any given air quality pattern, the effect of the distribution of physiological parameters is to generate a distribution that is fairly tight around the 50th percentile individual. For example, $95 \%$ of the population is estimated to be within $\pm 0.3 \% \mathrm{COHb}$ of the median adult value after exposure to the mid-range pattern with a peak 9 ppm, 8-hour average (Biller and Richmond 1982). 0.2.4 Recommended Outdoor Standard for Carbon Monoxide

Because of the lack of negative controlled human exposure evidence concerning the impact of coHb levels below $3.0 \%$ on individuals with cardiovascuiar 
TABLE D.6. Predicted COHb Response to Exposure to Constant CO Concentrations (EPA 1984)

Percent COHb Based on Coburn Equation (a)

Exposure Time

\begin{tabular}{rccccc}
\hline $\begin{array}{c}\text { Co } \\
\text { (ppm) }\end{array}$ & $\begin{array}{l}\text { Intermitent } \\
\text { Rest/Light } \\
\text { Activity }\end{array}$ & $\begin{array}{c}\text { Moderate } \\
\text { Activity }\end{array}$ & $\begin{array}{l}\text { Intermittent } \\
\text { Rest/Light } \\
\text { Activity }\end{array}$ & $\begin{array}{l}\text { Moderate } \\
\text { Activity }\end{array}$ \\
\hline 7.0 & 0.7 & 0.7 & 1.1 & 1.1 \\
9.0 & 0.7 & 0.8 & 1.4 & 1.4 \\
12.0 & 0.8 & 0.9 & 1.7 & 1.8 \\
15.0 & 0.9 & 1.1 & 2.1 & 2.2 \\
20.0 & 1.1 & 1.3 & 2.7 & 2.9 \\
25.0 & 1.2 & 1.5 & 3.4 & 3.6 \\
35.0 & 1.5 & 2.0 & 4.6 & 4.9 \\
50.0 & 2.0 & 2.7 & 6.4 & 6.5 \\
\hline
\end{tabular}

assumed parameters: alveolar ventilation rates $=1011$ ters/min (Intermittent rest/light activity) and 20 liters/min (moderate activity); hemoglobin = $15 \mathrm{~g} / 100 \mathrm{ml}$ (normal male); altitude = sea level; initia) colb level $=0.5$ percent; endogenous $C 0$ production rate $=0.007 \mathrm{ml} / \mathrm{min} ;$ blood yolume $=5500 \mathrm{ml}$, Haldane constant (measure of affinity of hemoglobin for $C 0$ ) $=218$; lung diffusivity for $\mathrm{CO}=30 \mathrm{ml} / \mathrm{min} / \mathrm{torr}$. 
TABLE D.7. ReTationship Between Human Carboxyhemogloben and Carbon Monoxide Concentrations (EPA 1984)

\begin{tabular}{|c|c|c|c|c|c|c|}
\hline \multirow{2}{*}{$\begin{array}{c}\text { Peak } \\
\text { CoHb } \\
\dot{b}\end{array}$} & \multicolumn{3}{|c|}{$\begin{array}{c}9 \mathrm{ppm}, 8-\mathrm{hr} \\
1 \text { Expected Exceedance }\end{array}$} & \multicolumn{3}{|c|}{$\begin{array}{l}12 \mathrm{ppm}, 8-\mathrm{hr} \\
1 \text { Expected Exceedance }\end{array}$} \\
\hline & $\begin{array}{c}\text { Low } \\
\text { Pattern }\end{array}$ & $\begin{array}{l}\text { Midrange } \\
\text { Pattern }\end{array}$ & $\begin{array}{l}\text { High } \\
\text { Pattern }\end{array}$ & $\begin{array}{l}\text { Low } \\
\text { Pattern }\end{array}$ & $\begin{array}{l}\text { Tidrange } \\
\text { Pattern }\end{array}$ & Pattern \\
\hline $\begin{array}{l}3.7 \\
3.5 \\
3.3 \\
3.1 \\
2.9 \\
2.7 \\
2.5 \\
2.3 \\
2.1 \\
1.9 \\
1.7 \\
1.5 \\
1.3 \\
1.1\end{array}$ & $\begin{array}{c}0.01 \\
0.05 \\
3 \\
39 \\
97 \\
100\end{array}$ & $\begin{array}{c}0.01 \\
0.02 \\
0.4 \\
5 \\
35 \\
88 \\
100 \\
100\end{array}$ & $\begin{array}{l}0.01 \\
0.02 \\
0.2 \\
2 . \\
10 \\
53 \\
98 \\
100 \\
100 \\
100\end{array}$ & $\begin{array}{c}0.01 \\
0.01 \\
0.2 \\
4 \\
36 \\
91 \\
100 \\
100 \\
100\end{array}$ & $\begin{array}{l}0.01 \\
0.01 \\
0.2 \\
2 \\
12 \\
49 \\
88 \\
99 \\
100 \\
100 \\
100\end{array}$ & $\begin{array}{l}0.01 \\
0.01 \\
0.1 \\
0.6 \\
2 \\
9 \\
36 \\
84 \\
100 \\
100 \\
100 \\
100 \\
100 \\
100\end{array}$ \\
\hline
\end{tabular}

aCOHb responses to fluctuating $\mathrm{CO}$ concentrations were dynamically evaluated using the Coburn model prediction of the CoHb level resulting from one hour's exposure as the initial coHb level for the next hour. The series of $]$-nour $\mathrm{CO}$ concentrations used were from 20 sets of actual air quality data. Each pattern was proportionaliy rolled back or up so that its peak 8-hour Co concentration equalied the level of the 8 -hour standard. of the 20 selected patterns, resuits from 3 patters are presented here. The low pattern tends to give the lowes: peak colib levels, the midrange pattern tends to give a midrange vaiue, and the high pattern tends to give the highest value.

bHaldane constant $=218$. Alveolar ventilation rate $=10$ i iters $/ \pi i n$. Altitude $=0.0 \mathrm{ft}$.

CThe estimation of distributions for each of the physiological parameters used in the Coburn model and the Monte Carlo procedure used to generate these estimates are discussed in the Sensitivity Analysis (Biller \& Richnond, 1982). 
disease, the margin of safety considerations and the precautionary nature of the Clean Air Act, the EPA staff (EPA 1984) is concerned that 8-hour standards at the upper end of the range 9 to $15 \mathrm{ppm}$ (10 to $17 \mathrm{mg} / \mathrm{m}^{3}$ ) would provide little or no margin of safety. Accordingly, the EPA staff (EPA 1984) recommends the following CO standards:

8-hour average: 9 to $12 \mathrm{ppm}\left(10\right.$ to $\left.14 \mathrm{mg} / \mathrm{m}^{3}\right)$

1-hour average: 25 to $35 \mathrm{ppm}$ (29 to $\left.40 \mathrm{mg} / \mathrm{m}^{3}\right)$.

\section{D.3 NITROGEN DIOXIDE}

The national ambient air quality standard for nitrogen dioxide $\left(\mathrm{NO}_{2}\right)$ has been $100 \mu \mathrm{g} / \mathrm{m}^{3}$ or $0.05 \mathrm{ppm}$ of average concentrations since 1970. Recently, EPA's Office of Air Quality Planning and Standards has completed its scientific review of $\mathrm{NO}_{2}$ studies and has recommended a new $\mathrm{NO}_{2}$ standard (EPA 1982). This section summarizes their heaith risk assessment and recommendations.

\section{D.3.1 Sensitive Population Groups}

On the basis of the available health data, the EPA staff is focusing on children and persons with asthma, chronic bronchitis, and emphysema as the most sensitive population groups (see Table D.8). Other persons, such as those with hay fever or liver, hematological or hormonal disorders, also may be affected at low levels of $\mathrm{NO}_{2}$. Because human experimental data are lacking for these Tatter groups, however, EPA staff (EPA 1982) intends to recommend to its Administrator that the potential effects on such persons should be considered only in determining the margin of safety for primary $\mathrm{NO}_{2}$ standard(s).

\section{3 .2 Controlled Human Exposure Studies ( $\mathrm{NO}_{2}$ with Other Pollutants)}

Controlled human exposure studies, summarized in Table 0.9 , provide little support for additive or greater-than-additive effects being associated with exposure to ambient concentrations of $\mathrm{NO}_{2}$ in the presence of other pollutants such as $\mathrm{O}_{3}, \mathrm{CO}$, or $\mathrm{SO}_{2}$. The principal exception is the increase in sensitivity to a bronchoconstrictor (acetylcholine) after exposure to a mixture containing $\mathrm{NO}_{2}, \mathrm{O}_{3}$, and $\mathrm{SO}_{2}$, reported by Von Nieding et al. (1977). The EPA staff explains that Von Nieding's findings are difficult to interpret because of 
TABLE D.8. Sensitive Population Groups to Nitrogen Dioxide (EPA 1982)

\begin{tabular}{|c|c|c|c|}
\hline $\begin{array}{l}\text { Sensitfye } \\
\text { Group }\end{array}$ & $\begin{array}{l}\text { Supporting } \\
\text { Evidence }\end{array}$ & $\begin{array}{l}\text { References for } \\
\text { Supportfing } \\
\text { Evidence }\end{array}$ & $\begin{array}{l}\text { Population } \\
\text { Estfmates }\end{array}$ \\
\hline Chilidren & $\begin{array}{l}\text { Children under age } 2 \text { exhiblt } \\
\text { increased prevalence of resplratory } \\
\text { infection when ifving in hoaes with } \\
\text { gas stoves. Children up to age il } \\
\text { exhiblted increased prevalence of } \\
\text { resplratory infections when living } \\
\text { in gas stove homes. }\end{array}$ & $\begin{array}{l}\text { Spefzer et al.. } \\
1980 \\
\text { Melfa et al.. } \\
1979\end{array}$ & $\begin{array}{l}\text { age } 0-5 \\
77.2 \text { milition* } \\
\text { age } 5-13 \\
36.6 \text { ail }\end{array}$ \\
\hline As thinatics & $\begin{array}{l}\text { Asthmatics reacted to lower levels } \\
\text { of } \mathrm{HO}_{2} \text { than nomal subjects in } \\
\text { controlled human exposure studies. }\end{array}$ & $\begin{array}{l}\text { herr et al.. } \\
\text { 1979 } \\
\text { Orehek et al.. } \\
1976\end{array}$ & $6.0 \mathrm{~m} 111 \mathrm{ton}$ \\
\hline $\begin{array}{l}\text { Chronfe } \\
\text { Bronchitics }\end{array}$ & $\begin{array}{l}\text { Chronic bronchitics reacted to } \\
\text { low levels of } \mathrm{NO}_{2} \text { in controlied } \\
\text { hum exposure studies. }\end{array}$ & $\begin{array}{l}\text { Kerr et al.. } \\
1979 \\
\text { Von Nieding et } \\
\text { al., } 1971 \\
\text { Yon Niedting et } \\
\text { al., } 1970\end{array}$ & 6.5 m111fon* \\
\hline Emphysematics & $\begin{array}{l}\text { Emphysend tics have signiffcantly } \\
\text { impaired respiratory systeans. } \\
\text { Because studies have shown that } \\
\text { No, impairs resplration by } \\
\text { increasing alruay resistance, it } \\
\text { is reasonable to assume that } \\
\text { emphysematics may be sensitive } \\
\text { to } \mathrm{NO}_{2} \text {. }\end{array}$ & $\begin{array}{l}\text { Yon Nledfing et } \\
\text { d1.j 1971 } \\
\text { Beji and Ulmer, } \\
1976 \\
\text { Orehek et al., } \\
1976\end{array}$ & 1.3 mitition" \\
\hline $\begin{array}{l}\text { Persons with } \\
\text { Tuberculosis, } \\
\text { Pneumonia, } \\
\text { Pleurisy, hay } \\
\text { Fever or other } \\
\text { Allergies }\end{array}$ & $\begin{array}{l}\text { Studies have shown that } \mathrm{NO}_{2} \\
\text { tincreases alrway resistance. } \\
\text { Persons who have or have had } \\
\text { these condftions may be } \\
\text { sufficiently fmpaired to be } \\
\text { sensftive to low levels of } \mathrm{NO}_{2} \text {. }\end{array}$ & $\begin{array}{l}\text { Yon Nieding et } \\
\text { d1., } 1971 \\
\text { geti and ulmer, } \\
1976 \\
\text { Orehek et al.. } \\
1976\end{array}$ & unknown \\
\hline $\begin{array}{l}\text { Persons with } \\
\text { Liver, elood } \\
\text { or Hormonal } \\
\text { ol sorders }\end{array}$ & $\begin{array}{l}\mathrm{NO}_{2} \text { Induces changes in } 1 \text { iver drug } \\
\text { metabolism, lung hormone metabol } 5 \text { sm. } \\
\text { and blood blochemistry. }\end{array}$ & $\begin{array}{l}\text { Menzel, 1980 } \\
\text { Milier et l., } \\
1980 \\
\text { Posin et al..., } \\
1978\end{array}$ & unknown \\
\hline
\end{tabular}

*1970 U.S. Bureas of Census and 1970 U.S. Matfonal Heal th Survey

$*$ *All subgroups 1 ifsted are not necessarlly sensitive to $\mathrm{NO}_{2}$ exposure at low levels. 
TABLE D.9. Effects on Pulmonary Function in Subjects Exposed to $\mathrm{NO}_{2}$ and Other Pollutants (EPA 1982)

\begin{tabular}{|c|c|c|c|c|}
\hline $\begin{array}{l}0.500_{3} ; 0.500_{3}+ \\
0.29 \mathrm{NO}_{2} ; 0.50 \mathrm{O}_{3}+ \\
.29 \mathrm{NO}_{2}+30 \mathrm{CO}\end{array}$ & 4-Hours & $\begin{array}{l}4 \text { heal thy } \\
\text { male } \\
\text { subjects }\end{array}$ & $\begin{array}{l}\text { Minimal change In } \\
\text { pulmonary function } \\
\text { caused by } \mathrm{O}_{3} \text { alone. } \\
\text { Effects not caused } \\
\text { by } \mathrm{NO}_{2} \text { or } \mathrm{CO} \text {. }\end{array}$ & $\begin{array}{l}\text { Hackney et al. } \\
1975\end{array}$ \\
\hline $\begin{array}{l}50 \mathrm{CO}+5 \mathrm{SO}_{2}: \\
4.8 \mathrm{NO}_{2}+50 \mathrm{CO}+5 \mathrm{SO}_{2}\end{array}$ & - & 3 subjects & $\begin{array}{l}\text { Increase in dust } \\
\text { retention from } 50 \% \\
\text { to } 76 \% \text { after } \mathrm{HO}_{2} \\
\text { was added to air } \\
\text { containing } \mathrm{SO}_{2} \text { and } \mathrm{CO} \text {. }\end{array}$ & $\begin{array}{l}\text { Schlipkoter } \\
\text { and Brockhaus, } \\
1963\end{array}$ \\
\hline
\end{tabular}


1) the uncertain health significance of altered sensitivity to bronchoconstrictors in healthy or sensitive subjects, 2) some uncertainties due to methodological differences between his techniques and those of other investigators, and 3) the lack of confirmation of the findings by other investigators. Because of these difficulties, the results of the Von Nieding study should not be used in determining the Towest concentration associated with adverse hea t:h effects. The study should be considered only as a factor in judging which standard(s) will provide an adequate margin of safety.

0.3.3 Community Epidemiology Studies

Community epidemiology studies of $\mathrm{NO}_{2}$ are summarized in Table D.10. Because of the methodological approach (i.e., use of Jacob-Hochheiser method! with the Shy et a1. (1970a, 1970b), Shy and Love (1979) and Pearlman et al. (1971) studies performed in Chattanooga, Tennessee, the health effects reported to be associated with $\mathrm{NO}_{2}$ levels from these studies cannot be quantitatively assessed. Also, at the time of the studies, trying to sort out any health effects caused by $\mathrm{NO}_{2}$ from effects caused by other pollutants found in the ambient air (e.g., zone, particulates, $\mathrm{SO}_{2}$ ) was very difficult. These prob]ems severely limit the usefulness of these studies for setting standards.

While the Kagawa and Toyama study (1975) shows some puImonary function effects related to $\mathrm{NO}_{2}$ concentrations, the results suggest that the observed respiratory effects are caused by a complex mixture of pollutants. Also, inadequate characterization of exposure to $\mathrm{NO}_{2}$ prevents the drawing of any firm conclusions about the relationship between $\mathrm{NO}_{2}$ exposure and resulting health effects.

At best we can oniy conclude that the findings of Shy et al. (1970a, 1970b), Shy and Love (1979), Pearlman et al. (1971), and Kagawa and Toyama (1975) are not inconsistent with the hypothesis that $\mathrm{NO}_{2}$, in a complex mix with other pollutants in the ambient air, adversely affects respiratory function and may cause illness in children. That is, although these studies do not provide clear evidence for positive associations between health effects and ambient exposures to $\mathrm{NO}_{2}$, neither do they suggest that negative or no associations 
TABLE 0.10. Effects of Exposure to $\mathrm{NO}_{2}$ on PuTmonary Function in Community Epidemiology Studies (EPA 1982)

\begin{tabular}{|c|c|c|c|}
\hline $\begin{array}{c}\text { Exposure Concentrations } \\
\text { (ppm) }\end{array}$ & Study Population & Reported Effects & References \\
\hline $\begin{array}{l}\text { Median hourly } 0.07 \mathrm{NO}_{2} \\
\text { Median hourly } 0.15 \mathrm{O}_{\mathrm{x}} \\
\text { Median hourly } 0.35 \mathrm{No}_{2} \\
\text { Median hourly } 0.02 \mathrm{O}_{x}\end{array}$ & $\begin{array}{l}205 \text { of fice workers } \\
\text { in L. A. } \\
439 \text { of fice workers in } \\
\text { San Francisco }\end{array}$ & $\begin{array}{l}\text { Ho differences in most tests. } \\
\text { Smokers in hoth citles showed } \\
\text { greater changes in pulmonary } \\
\text { function than ion-smokers. }\end{array}$ & $\operatorname{Linn}_{1976}$ et al.. \\
\hline $\begin{array}{l}\text { High exposure area: } \\
24 \mathrm{hr} \text { high } 0.055 \mathrm{HO}_{2} \\
.035 \mathrm{NO}_{2} \\
1 \text {-hr mean } \\
\text { High exposure area } 0.14 \mathrm{NO}_{2} \\
\text { to } 0.30 \mathrm{HO}_{2} \\
\text { Low exposure area } 0.06 \mathrm{HO}_{2} \\
\text { to } 0.09 \mathrm{HO}_{2}\end{array}$ & $\begin{array}{l}128 \text { traffic policemen } \\
\text { in urban Boston and } \\
\text { l40 patrol officers in } \\
\text { nearby suburbs }\end{array}$ & $\begin{array}{l}\text { No difference in various } \\
\text { pulmonary function tests }\end{array}$ & $\begin{array}{l}\text { Speizer and } \\
\text { Ferris, } 1973 \\
\text { Burgess et al. } \\
1973\end{array}$ \\
\hline $\begin{array}{l}\text { High exposure group: } \\
\text { Estimated } 1-\mathrm{hr} \text { max } 0.25 \text { to } \\
0.51 \mathrm{N0} 2 \\
\text { Antlual mean } 24-\mathrm{hr} 0.051 \mathrm{NO}_{2} \\
\text { Low Exposure groups: } \\
\text { Estimated } 1 \mathrm{hr} \text { max } 0.12 \text { to } \\
0.23 \mathrm{H}_{2} \\
\text { Annual mean } 24 \mathrm{hr} 0.01 \mathrm{H}_{2}\end{array}$ & $\begin{array}{l}\text { Nonsmokers in L.A. } \\
\text { (adult) }\end{array}$ & $\begin{array}{l}\text { No differences found in } \\
\text { several ventilatory } \\
\text { measurements including } \\
\text { spirometry and flow } \\
\text { volume curves }\end{array}$ & $\begin{array}{l}\text { Cohen et al.. } \\
1972\end{array}$ \\
\hline $\begin{array}{l}\text { l hr conc. at time of } \\
\text { testing }(1: 00 \mathrm{p.lil.}) \\
0.02 \text { to } 0.19 \mathrm{No}_{2}\end{array}$ & $\begin{array}{l}20 \text { school age children } \\
11 \text { years of age }\end{array}$ & 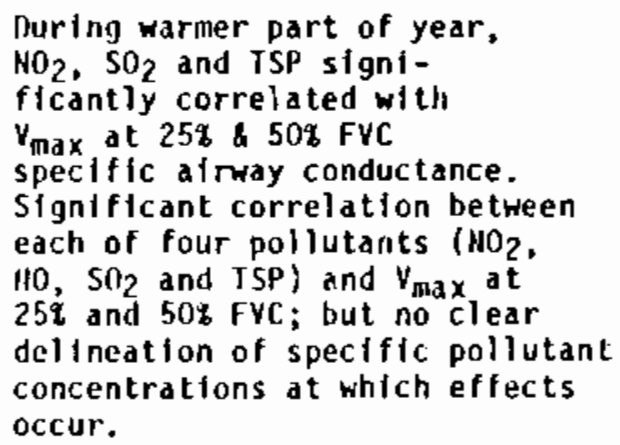 & $\begin{array}{l}\text { Kagawa and } \\
\text { Toyama, } 1975\end{array}$ \\
\hline
\end{tabular}


exist between such varjables. Littie or no evidence of health effects at ambient concentrations of $\mathrm{NO}_{2}$ is provided by other community epidemiological studies.

It should be recognized that the community epidemiology studies cited and discussed above did not take into account exposure to, and effects of, indoor air pollutants such as $\mathrm{NO}_{2}$ generated by the use of gas stoves.

\section{D.3.4 Community Studies Involving Gas Stoves}

Table 0.11 summarizes reported effects of exposure to $\mathrm{NO}_{2}$ in the home in community studies involving gas stoves. In evaluating the evidence from the Melia et al. (1977), Melia, du V. Florey and Chinn (1979), and Speizer et al. (1980) studies, the major uncertainties are what agent(s) caused the reported health effects and, if those agents are $\mathrm{NO}_{2}$, then what exposure levels and patterns (concentration, averaging time, and frequency) are associated with the reported effects. Possible confounding and covarying factors which may be related to the increased prevalence rate of respiratory iliness and symptoms observed in children in homes with gas stoves include humidity, socioeconomi: status, and pollutants other than $\mathrm{NO}_{2}$, such as carbon monoxide and hydrogen cyanide, which are emitted when gas combustion occurs. However, there is no evidence that carbon monoxide or hydrogen cyanide is given off in dangerous quantities by gas stove combustion, and there is also no evidence that these pollutants cause effects such as increased respiratory symptoms or illness. The contribution, if any, to increased respiratory symptoms or illness due to increased humidity or water vapor in gas stove homes requires further research.

Other factors, such as outdoor pollution levels and exposure to parenta smoking, may have contributed to the overall effect observed in the Melia et al. (1977), Melia, du V. Florey and Chinn (1979), and Speizer et al. (1980) studies. There is, however, no evidence in the studies to suggest that thes? factors differ for children living in homes with electric versus gas stoves.

It should be noted that, while the animal studies provide some evidence that $\mathrm{NO}_{2}$ impairs respiratory defense mechanisms, these studies are conducted at $\mathrm{NO}_{2}$ exposure levels believed to be considerably higher than those experienced in the gas stove homes. 
TABLE D.11. Community Studies of Nitrogen Dioxide Involving Gas Stoves (EPA 1982)(a)

\begin{tabular}{|c|c|c|c|}
\hline 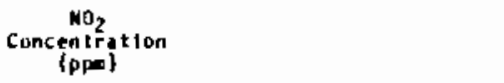 & Study Population & Reported Effects & Peferences \\
\hline 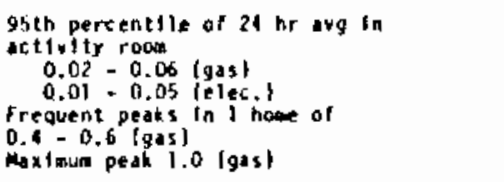 & 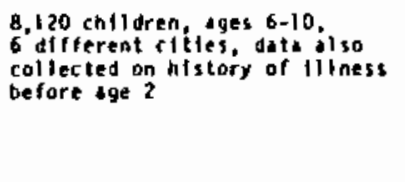 & 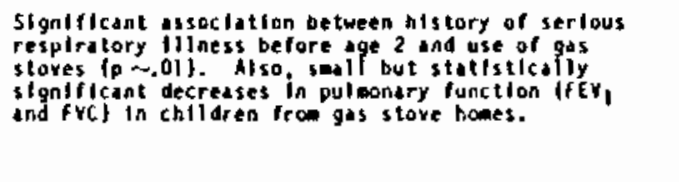 & Spelzer et al.. 1980 \\
\hline $\begin{array}{l}\mathrm{HC}_{2} \text { concentratlons net measured } \\
\text { at itme of study. }\end{array}$ & 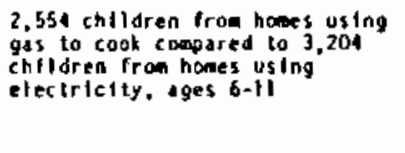 & 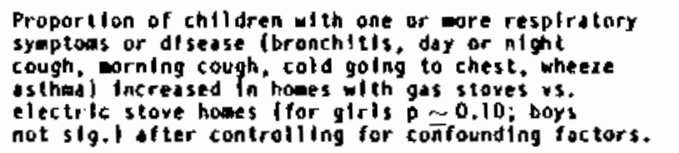 & Hel1s et $11 ., 197$ \\
\hline $\begin{array}{l}\text { Wy concentrations nat measured in } \\
\text { suser homes studied for hed th effects. }\end{array}$ & 4827 ch1ldren. squs 5-10 & 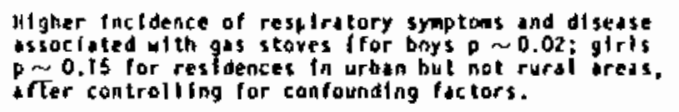 & Hel1. et +1.., 1979 \\
\hline 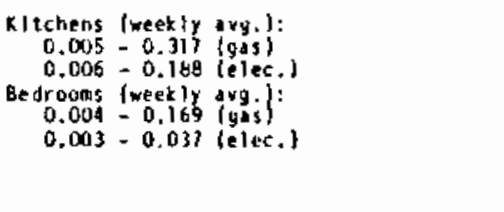 & 808 entldren, ages $6-7$ & 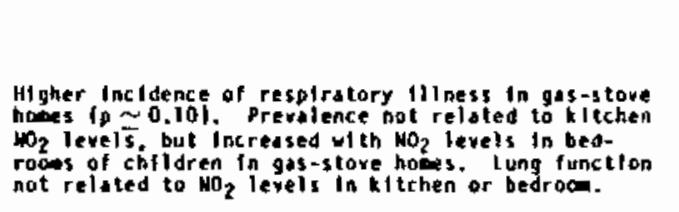 & 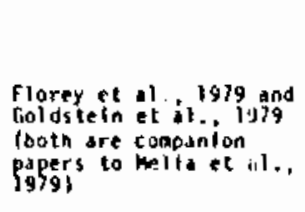 \\
\hline 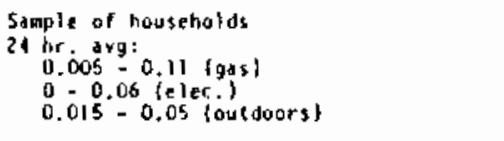 & $\begin{array}{l}\text { 128 children, ages } 0-5 \\
346 \text { children; ages t-10 } \\
421 \text { children, oges } 11-15\end{array}$ & 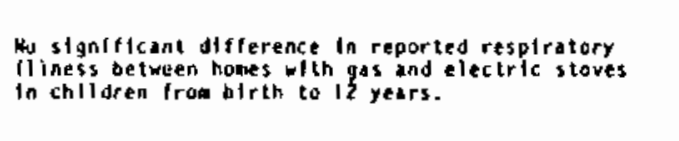 & $\begin{array}{l}\text { Hitchell et ol.. } 1974 \\
\text { See diso keller et di.. } \\
\text { lg79 }\end{array}$ \\
\hline $\begin{array}{l}\text { Somple of household same as reporled } \\
\text { shove tust in no new mont torting reported. }\end{array}$ & 174 children under 12 & $\begin{array}{l}\text { No evidence that cooking mode } 13 \text { assactated with the } \\
\text { incidence of acute resplratory inlaess. }\end{array}$ & Keller et $\& 1 ., 1979$ \\
\hline See dbove for monttoring. & $\begin{array}{l}\text { Hous exives cook Ing rith gas } \\
\text { stores, compare: to those } \\
\text { couk Ing with electric stoves. } \\
\text { 146 households. }\end{array}$ & 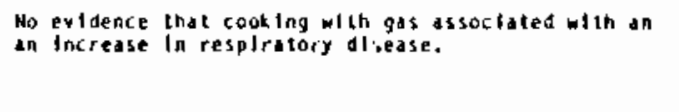 & kelter et al. . 1979 \\
\hline See above for monituring. & Himbers of $\$ 41$ househuids & $\begin{array}{l}\text { No slgniflcant difference in reported respsratory } \\
\text { iilness among doults in gas vs elect ic cock Ing homes }\end{array}$ & $\begin{array}{l}\text { Mutcheit ez al., } 1974 \\
\text { See diso kelier os } 1 . . \\
1979\end{array}$ \\
\hline $\begin{array}{l}\text { Piellminary medsuremerils pesk hourly } \\
\text {-25-0.50. max } 1.0\end{array}$ & $\begin{array}{l}\text { Howserlyes coukting with gas } \\
\text { sloves. compared ta those } \\
\text { cookting with electric stoves }\end{array}$ & $\begin{array}{l}\text { Ho thcredsed resplratory tilness assicliated wlth gas } \\
\text { stove usage. }\end{array}$ & U.5., [PA, $19 / 6$ \\
\hline
\end{tabular}

Aleposures in gas stove homes were to $\mathrm{HO}_{2}$ plus oltier gas combustion products.

buffects reported in published references are sumarized here. However. the Criterla Documeat warns that considerable caution
should be used in drawling fin conclustons frox these studies. 
The authors of the Speizer et al. (1980) study have hypothesized that repeated peak values are probabiy the most important exposures in causing the effects observed in the gas stove homes. Their judgment is in part based on the fact that there are no intermittent short-term ( $1 / 2$ hour-2 hour) $\mathrm{NO}_{2}$ peak concentrations in electric stove homes and that long-term (24-hour or longer) concentrations in gas stove homes are not that much higher than in electric stove homes.

The daily peak 2-hour $\mathrm{NO}_{2}$ levels observed in 3 homes monitored by Cote, Wade and Yocom (1974) provide the best, although rough, estimate of the shortterm (1-2 hour) levels that may have occurred in the gas stove homes in the Speizer et a1. (1980) study. It is recognized that short-term levels in particular homes in the Six-City Study may have varied considerably in magnitude or frequency of peak levels from the homes in the cote, Wade and Yocom (1974) study due to variation in gas stove usage, ventilation conditions, and desigrs of homes.

\section{D.3.5 Recommended Standard for Nitrogen Dioxide}

Based on best available scientific information presented earlier, the EPA staff has made the following recommendations on the national ambient air quality standard for $\mathrm{NO}_{2}$ (EPA 1982):

- A 1-hour average $\mathrm{NO}_{2}$ standard could be established at some level below $0.5 \mathrm{ppm}$, or at the range of $0.15 \mathrm{ppm}$ to $0.30 \mathrm{ppm}$, which would have to be met for a specified number of days in the calendar year.

- An annual standard ranging from 0.05 to 0.08 ppm is recominended as an alternative to establishing the above short-term standard.

An annual standard in the range of 0.05 to $0.08 \mathrm{pprn}\left(90\right.$ to $\left.150 \mu \mathrm{g} / \mathrm{m}^{3}\right)$ would appear to provide adequate protection against the potential and uncertain heaith effects that may be associated with exposure to short-term $\mathrm{NO}_{2}$ levels. Such a standard could be used as a surrogate for a short-term standard. An annual standard also would provide some, although unquantifiable, protection against possible adverse health effects from long-tern exposure.

The lack of scientifically demonstrated health effects in humans from $\mathrm{NO}_{2}$ exposure in concentrations below $0.5 \mathrm{ppm}$ could be interpreted to mean that 
there is no need for an $\mathrm{NO}_{2}$ National Ambient Air Quality Standard. However, such an interpretation would ignore the cumulative evidence from controlled animal and human exposure studies, and community indoor studies, which strongly suggest that $\mathrm{NO}_{2}$ may cause adverse health effects in sensitive population groups exposed to $\mathrm{N}_{2}$ levels at or near existing ambient levels (EPA 1982).

\subsection{FORMALDEHYDE}

In this section, human sensitivity to formaldehyde, its short- and longtern effects, and indoor concentrations of formaldehyde are discussed.

\section{D.4.1 Human Sensitivity to Formaldehyde}

The effects on humans of exposure to low formaldehyde concentrations partialiy result from formaldehyde's properties as a sensitizer and strong irritant (Gupta 1982). Controlled exposure studies have reported effects on humans at concentrations as low as $10 \mu \mathrm{g} / \mathrm{m}^{3}$ (Schuck, Stephens and Middleton 1966). Between 10 and $70 \mu \mathrm{g} / \mathrm{m}^{3}$, humans reach thresholds for eye irritation and odor detection, as noted in Table D.12, which lists the effects of subjects exposed to various levels of formaldehyde for various durations. Controlled experimental conditions produced statistically significant irritant responses of the eye, nose, and throat at $240 \mu \mathrm{g} / \mathrm{m}^{3}$ and above in healthy adults (Anderson 1979; Weber-Tschop, Fischer and Grandjean 1977; and Rader 1974). A7though the odor threshold for formaldehyde is reported at $60 \mu \mathrm{g} / \mathrm{m}^{3}$ by some subjects, it is most commonly detected at $1.2 \mathrm{mg} / \mathrm{m}^{3}$ (National Acadeny of Sciences 1981). Gupta, U1samer and Preuss (1982) note that repeated exposure to formaldehyde can cause certain individuals to become sensitized and to exhibit allergic dermatitis (Horsfall 1934; Pirila and Kilpio 1949; Hovding 1969) or mild to severe asthmatic reactions (Popa, Teculescu and Stanescu 1969; Alanko, Keskiner and Saarinen 1977; Hendrick and Lane 1977). These responses may increase in severity if the individuals have continued exposure to formaldehyde (Shellow and Altman 1966; Skogh 1959; Breysse 1977). These controlled studies indicated that the severity and number of subjects that respond to formaldehyde increases as the airborne concentration level increases. 
IABLE D.12. Effects in Subjects Exposed to Formaldehyde

\begin{tabular}{|c|c|c|c|}
\hline $\begin{array}{l}\text { Concentration } \\
-\left(\mu \mathrm{g} / \mathrm{m}^{3}\right) \\
\end{array}$ & $\begin{array}{l}\text { Exposure } \\
\text { Duration } \\
\end{array}$ & $\begin{array}{l}\text { Reported } \\
\text { Effect }\end{array}$ & Reference \\
\hline 10 & 5 minutes & Eye irritation & $\begin{array}{l}\text { Schuck, Stephens and } \\
\text { Middleton (1966) }\end{array}$ \\
\hline $60-70$ & minutes & Odor threshold & $\begin{array}{l}\text { Wahren (1980) } \\
\text { Melekhina (1964) }\end{array}$ \\
\hline 80 & minutes & Optical chronaxy threshold & Melekhina (1964) \\
\hline 100 & Filinutes & $\begin{array}{l}\text { Threshold to affect the } \\
\text { functional state of } \\
\text { cerebral cortex }\end{array}$ & Melekhina (1964) \\
\hline 240 & 1 hour & $\begin{array}{l}\text { Eye, nose, and throat } \\
\text { irritation }\end{array}$ & Rader (1974) \\
\hline 300 & 5 hours & $\begin{array}{l}\text { Dryness of nose and throat, } \\
\text { decrease in mucus flow rate }\end{array}$ & Anderson (1979) \\
\hline 1000 & 1 minute & $\begin{array}{l}\text { Altered functional state of } \\
\text { cerebral cortex }\end{array}$ & $\begin{array}{l}\text { Feldman and } \\
\text { Bonashevskaya (1971। }\end{array}$ \\
\hline 1000 & 10 minutes & $\begin{array}{l}\text { Irritation of upper tract } \\
\text { and eyes, accelerated } \\
\text { breathing, EEG changes } \\
\text { such as aipha rhythm } \\
\text { enhancement, changes of } \\
\text { automatic nervous system }\end{array}$ & Sgibnev (1968) \\
\hline 1700 & 1 minute & $\begin{array}{l}\text { Eye sensitivity to light } \\
\text { lowered in unacclimated } \\
\text { group }\end{array}$ & Jeiekhina (1964) \\
\hline 5000 & 1 minute & $\begin{array}{l}\text { Unbearable without } \\
\text { respiratory protection }\end{array}$ & Wiley (1980) \\
\hline
\end{tabular}

\section{D.4.2 Short-Term Impacts}

The Consumer Product Safety Conmission (CPSC) has received numerous com-plaints about formaldehyde concentrations in residential buildings. The CPSC, reports that residential concentrations of 10 to $120 \mu \mathrm{g} / \mathrm{m}^{3}$ have been identified as causing nausea, eye, nose and throat irritation, headaches, vomiting, and stomach cramps (Greisemer et al. 1980). The research information compiled b./ Gupta, Ulsamer and Preuss (1982) indicates that the human threshold for shortterm exposure varies widely. 
The National Academy of Sciences (NAS) conciuded that there is no population threshold for the irritant effects of formaldehyde (NAS 1980). Persons sensitized to formaldehyde and persons with hyperactive airways may respond more severely (NAS 1981). The Academy has also estimated that $10 \%$ to $12 \%$ of the U.S. population may have hyperactive airways, which may make them more susceptible to the irritant effects of formaldehyde (NAS 1981).

\section{D.4.3 Long-Term Impacts}

The long-term concern over exposure to formaldehyde is based on the observation of nasal carcinogenisis in rats exposed to formaldehyde vapors (Gupta, UIsamer and Preuss 1982). It is not clear, however, how this information relates to human risk. Gupta, Ulsamer and Preuss (1982) does conclude, as did the Federal Panel on Formaldehyde (Greisemer et al. 1980) that:

"formaldehyde should be presumed to pose a carcinogenic risk to humans. ...that efforts should be made to reduce or eliminate human exposure to formaldehyde."

These conciusions are supported further by the deliberations of the International Agency for Research on Cancer, which concluded in October 1981 that (a) sufficient evidence indicates that formaldehyde gas is carcinogenic to rats; (b) the epidemiological studies are inadequate to assess the carcinogenicity of formaldehyde in humans; and (c) at present, formaldehyde gas should be considered, for practical purposes, as if it represented carcinogenic risk to humans (Gupta, Ulsamer and Preuss 1982).

\section{D.4.4 Indoor Concentrations}

Formaldehyde concentrations vary across a wide range of levels and are influenced by the type of residence and whether urea-formaldehyde foam insulaon (UFFI) was used as an insulation material. Neither the baseline or the proposed standard residence uses UFFI, so the values of formaldehyde concentration in residences, shown in Table D.13, are for residences without UFFI. Table 0.14 shows preliminary formaldehyde emission rates from materials found in residences as measured by the Inhalation Toxicology Research Institute (Gupta, U7samer and Preuss 1982). Indoor concentrations of formaldehyde can also result as a product of combustion. Table 0.15 shows the average $24-h o u r$ formaldehyde contribution from gas stoves. 
TABLE D.13. Formaldehyde Concentration in Residences (Gupta, Ulsamer and Preuss 1982)

\begin{tabular}{|c|c|c|c|}
\hline \multirow[b]{2}{*}{ Type of Residence } & \multirow[b]{2}{*}{$n$} & \multicolumn{2}{|c|}{$\begin{array}{l}\text { Formaldehyde } \\
\text { Concentration }\left(\mathrm{\mu g} / \mathrm{m}^{3}\right)\end{array}$} \\
\hline & & Range & Average \\
\hline Ambient & 156 & $0-100$ & 10 \\
\hline Homes & 41 & $10-100$ & 40 \\
\hline Mobile homes & 431 & $10-3500$ & 460 \\
\hline
\end{tabular}

TABLE D.14 Formaldehyde Emission From Selected Products

\begin{tabular}{|c|c|}
\hline Product & $\begin{array}{c}\text { Emission rate }(a) \\
\quad(1 \mathrm{~g} / \mathrm{g} \text {-day }) \\
\end{array}$ \\
\hline Particle board & $0.4-8.1$ \\
\hline Plywood & $0.03-9.2$ \\
\hline Paneling & $0.84-2.1$ \\
\hline Fiberglass insulations & $0.3-2.3$ \\
\hline Clothing & $0.2-4.9$ \\
\hline Drapery & $N D^{(b)}-3.0$ \\
\hline Paper products & $0.03-0.36$ \\
\hline Carpet & $N^{(b)}-0.06$ \\
\hline
\end{tabular}

(a) The emission range represents two or more tests, on three to five samples for each product category, using conditions closely resembling Japanese Desiccator Test.

(b) $\mathrm{ND}=$ not detectabie.

\section{D.5 RADON}

The potential lung cancer risk from exposure to short-lived radioactive daughters of radon-222 in residential environments has become increasingly recognized. Surveys of radon daughters in residential structures have showr that radon in soil air is the primary source of indoor radon (wilson 1984). The principal source of radon is the distribution of the radioactive elements uranium, thorium and potassium-40 in bedrock and other materials. These 
TABLE 0.15. Forma]dehyde Contributions from Selected Combustion Sources (Hawthorne and Matthews 1985)

\begin{tabular}{|c|c|c|c|}
\hline Source & $\begin{array}{l}\text { Modeled } \\
\text { Duty Cycle }\end{array}$ & $\begin{array}{l}\text { Approximate } \\
\text { Measured Emission } \\
\text { Rate (mg/h) }\end{array}$ & $\begin{array}{c}\text { Emission } \\
\text { Average } \\
\text { Over } 24-h(\pi / h)\end{array}$ \\
\hline $\begin{array}{l}\text { Gas stove } \\
\text {-burner } \\
\text {-oven }\end{array}$ & $\begin{array}{l}0.7 \mathrm{~h} / \text { day } \\
0.7 \mathrm{~h} / \text { day }\end{array}$ & $\begin{array}{l}15 \\
20\end{array}$ & $\begin{array}{l}0.7 \\
0.7\end{array}$ \\
\hline $\begin{array}{l}\text { Kerosene heate } \\
\text { - convective } \\
\text { - radiant }\end{array}$ & $\begin{array}{l}8 \mathrm{~h} / \text { day } \\
8 \mathrm{~h} / \text { day }\end{array}$ & $\begin{array}{l}1 \\
4\end{array}$ & $\begin{array}{l}0.3 \\
1.3\end{array}$ \\
\hline Cigarettes & $10 \mathrm{cig} /$ day & $\sim 1$ & 0.6 \\
\hline
\end{tabular}

elements occur, generally at very low concentrations, in all rock and soil types (Wilson 1984). Several important factors have been identified as controlling the level of radon gas that may accumulate in a residence. Those factors include the rate that indoor air is exchanged with outdoor air, the way the residence is coupled with the soil, the permeability of the soil iayers under the residence, the radon content of the soil, and the amount of time and extent the residence is under negative pressure compared to the soil.

\section{D.5.1 Exposure}

Bale(a) and Harley (1953) were the first to note that the lung cancer hazard from exposure to radon and radon daughters was from the alpha dose delivered through lung deposition of the short-lived daughters of radon $\left[{ }^{218} \mathrm{Po}(\mathrm{RaA}),{ }^{214} \mathrm{~Pb}(\mathrm{RaB}),{ }^{214} \mathrm{Bi}(\mathrm{RaC})\right.$ and $\left.{ }^{214^{4}} \mathrm{Po}\left(\mathrm{RaC}^{\prime}\right)\right]$ and not from the radon itself. Two alpha emitters, ${ }^{218} \mathrm{Po}(\mathrm{RaA})$ and ${ }^{214} \mathrm{Po}\left(\mathrm{RaC}^{\prime}\right)$, uitimately deliver the carcinogenic dose to tracheobronchial epithelium. The complexity in the dose estimates required to account for daughter deposition, radioactive buildup and decay, removal by physiological clearance processes, and physical dose calculations to specific cells in bronchial mucosa has been detailed by many authors and considered by various national and international organizations.

(a) Bale, H. F. 1951. "Hazards Associated with Radon and Thoron." Memo, March 14, 1951, Div. Biol. and Med., Atomic Energy Commission, Washington, D. C. 
For more information on exposure, see AltshuJer, Nelson and Kuschner 1964; Jacobi 1964, 1972, 1977; Haque 1966, 1967; Haque and Collinson 1967; Parker 1969; Walsh 1970, 1971, 1979; Harley and Pasternack 1972, 1981; Nelson et al. 1974; Fry 1977; McPherson 1979; Jacobi and Eisfeld 1980; James, Greenhalgh and Birchal1 1980; James, Jacobi and Steinhausler 1981; Hofmann 1982; Wise 1982; United States Pubiic Health Service (USPHS) 1957, 1961; Federal Radiation Councit (FRC) 1967; Joint Committee on Atomic Energy (JCAE) 1967, 1969; International Commission on Radiological Protection (ICRP) 1977, 1981; United Nations Scientific Committee on the Effects of Atomic Radiation (UNSCEAR) 1972 , 1977; National Institute for 0ccupational Safety and Health/National Institute of Environmental Health Sciences (NIOSH/NIEHS) 1971; and National Academy of Sciences (NAS) 1972, 1980.

Historically, exposure is defined in terms of the air concentration of radon daughters in units of working level (WL). A working level is defined to be a concentration of short-lived radon daughters (through $\mathrm{RaC}^{\prime}$ ) totaling $1.3 \mathrm{x}$ $10^{5} \mathrm{MeV}$ of potential aipha energy per liter of air. A working level month (WLM) is an equivalent exposure to $1 \mathrm{WL}$ for 173 hours. These definitions avoid the problems of disequilibrium of the daughters and avoid the need to determine whether the daughters are attached to a carrier aerosol or remain unattached. Attached radon daughters deposit with some finite probability to the lung surfaces; unattached radon daughters deposit in the respiratory tract with virtual $100 \%$ probability. Thus, the mix of attached and unattached radon daughters $i j$ an important consideration in assessing lung dosimetry. The unattachment fraction values found in the workplace and in the environment are reasonably constant and not sufficiently different to cause a large disparity in the radiological dose assessment of environmental and occupational exposures to radon daughters. The same can be said for the other parameters influencing radon daughter lung dose, such as differences in daughter product equilibrium, particle size distributions, breathing patterns, bronchial morphometry, and physiologic clearance processes.

\section{D.5.2 Lung Dosimetry Models}

The more recent lung dosimetry models for radon daughters are in substartial agreement with one another and place the bronchial epithelium exposure-1;0- 
dose conversion factor at about $0.5 \mathrm{rad} / W L M$ for uranium miners. The dose per unit cumulative exposure has also been derived for environmental conditions (Harley and Pasternack 1981). Close agreenent was found for the adult male (0.71 rad/WLM), adult female $(0.64 \mathrm{rad} / \mathrm{W}(M)$, a 10-year-old child $(1.2 \mathrm{rad} / \mathrm{WL}(M)$, and a 1 -year-old infant $(0.64 \mathrm{rad} / \mathrm{WLM})$. The small differences primarily reflect the reduced breathing rates during normal environmental exposures, lung morphometry, particie size differences, and the increased percentage of unattached RaA in ordinary atmospheres ( $7 \%$ environmental vs. $\sim 4 \%$ in mines). These conversion factors indicate that a cumulative exposure in the environment is somewhat more effective in delivering a radiation dose than exposures under working conditions in a mine. Certain home energy conservation practices could produce exposure-to-dose conversion factors even closer to those calculated for the miners as a result of lower RaA unattachment fractions from dustier home conditions. In some treatments of modeling of risk from radon daughter exposure, a tendency to artificially lower the cumulative exposure in the environment has been evident, presumably to account for decreased breathing rates under nonworking conditions. (a)

\section{D.5.3 Radon Daughter Epidemiology Studies}

The epidemiological data derived from many types of underground mining show a relatively consistent relationship between lung cancer incidence and exposure to radon daughters in WLM. This underlying consistency is probably related to the relatively narrow range of bronchial dose per WLM. Assessing the risk of attributable lung cancer through human epidemiological studies is difficult because the detailed information required is not avaitable. In the ideal case, the exposure of each miner as a function of time would be long enough and the followup period would be long enough for all of the group to have died from lung cancer or other causes. In addition, separating attributable lung cancers from those arising spontaneously or from cigarette smoking

(a) Environmental Protection Agency (EPA). 1980 (Draft). Draft Environmental Impact Statement (DEIS) for Remedial Action Standards for Inactive Uranium Processing Sites. EPA 52014-80-011, Environmental Protection Agency, Research TriangTe Park, North Carolina. 
would be possible. The cumulative exposure, person-years at risk, and the number of attributable iung cancers would allow a risk factor to be calculated exact7y.

The present data do not fulfill the above requirements because exposures are only estimates and the followup periods are not long enough. Nevertheless, by recognizing the limitations of the data, we can estimate a mean risk factor based on the available epidemiological data.

Human data are now available from several groups of underground metal ore miners: the U.S., Canadian, and Czechoslovakian uranium miners; Swedish and British iron miners; Swedish lead and zinc miners; and Newfoundland fluorspar miners. Although other potential carcinogens such as diesel smoke, traces of arsenic or nickel and iron ore are found in these mines, the lung cancer response appears to be predictably based on radon daughter exposure. Some of these studies have divided the workers into subgroups on the basis of exposure. Eighteen of these subgroups were selected as being most suitable (considerinc both epidemiological and environmental data) for quantitative treatment of the lower exposure levels (Archer, Radford and Axelson 1979). In addition to this treatment, these mining populations have been reviewed by other authors and organizations (NIOSH/NIEHS 1971; NAS 1972, 1980; SevC, Kunz and Placek 1976; Jorgensen 1973; Axelson and Sunde17 1978; Snihs 1973, 1974; Renard 1974; Devilizers and Windish 1964; Wright and Couves 1977; McCullough, Stocker and Makepeace 1979; UNSCEAR 1977; Evans et al. 1981; and Radford 1981a).

The data thus far suggest that an absolute threshold exposure for lung cancer induction is highly unlikely. This is consistent with current views of radiation biology and radiation protection that radiation-induced cancer is a stochastic process. Some argue that the lung cancer mortality data at the lowest reported exposures are not statisticaliy different froin expected (Evans 1967; Stranden 1980) and that at least a "practical" threshold for radon daughter carcinogenesis may exist. Archer, Radford and Axelson (1979) conclude irom their analysis of the 18 subyroups that if a threshold exists, it is below :0 to 30 WLM. Snihs $(1973,1974)$ considers the lowest underground exposure resulting in an apparent increase in lung cancer deaths in Swedish miners to be 
about 15 WLM, although he states that drawing conciusions about the exposureresponse relationship below 100 WLM is impossible. Hewitt (1979) concludes from the analysis of Canadian uranium miners that if a threshold exists, it is below 60 WLM. Thus, the possibility exists that environmental radon daughters do not induce lung cancer.

The incidence of lung cancer attributable to radon daughter exposure observed in the various mining subgroups ranges overal1 from about 1.5 to 50 cases per WLM/year $/ 10^{6}$ persons, with a reasonabie average value of $10 \mathrm{x}$ $10^{-6}$ per person per year per WLM. This average value has been accepted in the lung cancer estimation model of Harley and Pasternack (1981) as being reasonably realistic when predictive data are compared to background (normally occurring) Tung cancer incidence in nonsmokers from environmental exposure to radon.

In estimating the effect of radon daughter exposure at environmental levels (normally less than about 20 WLM per ilfetime), the attributable risk at high exposures must somehow be extrapolated to the low exposure region. With the conventional method, the extrapolation is linear, even though some studies suggest that exposures may be even more efficient in inducing Tung cancer as the exposure rate approaches background levels (Archer 1978).

\subsubsection{Influence of Cigarette Smoke}

The effect of cigarette smoke on radiation-induced cancer probabilities is still unresolved. During periods of relatively short followup (15 to 25 years), cigarette smoking is associated with a markedly increased incidence of lung cancer in miners. During periods of followup that are 30 to 60 years after initial exposure, lung cancer incidence is reported to be either somewhat greater among nonsmokers than smokers (Axelson and Edding 1980) or about the same (Radford 1981b). The human evidence has been confirmed in studies with beagle dogs; in those studies, dogs that smoked had fewer respiratory tract tumors than dogs that did not smoke, but they had comparable radon daughter exposures (Cross et al. 1978). The data on cigarette smoking suggest that smoking's principal roie in lung cancer among uranium miners is to accelerate the appearance of cancers induced by radiation. The role of smoking at reduced radon levels is unknown. 


\section{D.5.5 Animal Studies}

Animal studies were conducted several decades ago in initial attempts to identify the nature and levels of uranium mine air contaminants that were responsible for producing the lung cancers observed among uranium mining populations. Many of these studies were concerned with early effects or short-ter'n pathologic changes (Jansen and Schultzer 1926; Read and Mottram 1939; Jackson 1940). In these studies also, exposures were primarily based on radon gas concentrations, thus leaving little or no information on the radon daughter concentrations that subsequently have been shown to contribute the greatest radiation dose to the lung. The earlier studies in which lung tumors were produced were methodologically or statistically inadequate to show an unequivocal association of lung tumors after exposure to radon or radon daughters (Huech 1939; Rajewsky, Shraub and Shraub 1942a, 1942b; Kushneva 1959).

Beginning in the 1950s, a growing concern emerged that the increased incidence of respiratory cancer observed in the European uranium mining population would also be found in the U.S. mining population (Seven State Uranium Mining Conference 1955; Wagoner et al. 1964). Systematic studies were subsequently begun in this country to identify the agents responsible for the excess lung cancer and to develop exposure-response relationships with animals. The importance of accurately determining the levels of radon daughter radionuclides in mine air was also noted by several investigators (Bale and Shapiro 1956; Harley 1953). Researchers at the University of Rochester began to focus attention on the biological and physical behavior of radon daughters as well as their contribution to the radiation dose of the respiratory tract (Harris 19i4; Morken 1955). (a) Shapiro (1954) exposed rats and dogs to several levels of radon alone and in the presence of radon daughters attached to "room dust" aerosols. He showed that the degree of attachment of radon daughters to carrier dust particles was a primary factor influencing the radiation dose $t$ )

(a) Also Bale, W. J. 1951. "Hazards Associated with Radon and Thoron." Memo, March 14, 1951, Div. Biol. and Med., Atomic Energy Commission, Washington, D.C. 
the airway epithelium and demonstrated that this dose was due primarily (>95\%) to the short-lived radon daughters $\operatorname{RaA}\left({ }^{218} \mathrm{Po}_{0}\right)$ and $\mathrm{RaC}^{\prime}\left({ }^{214} \mathrm{Po}\right)$, rather than to the parent radon.

Cohn, Skow and Gong (1953) reported relative levels of radioactivity found in the nasal passages, trachea, plus major bronchi, and the remainder of rat lungs after exposure to radon and radon daughter products. The respiratory tracts of animals that inhaled radon plus its decay products contained 125 times more activity compared with those of animals that inhaled radon alone.

Beginning in the mid-1950s, Morken initiated a pioneering series of experiments to evaluate the biological effects of inhaled radon and radon daughters in mice, with later experiments using rats, as well as beagle dogs (Morken and Scott 1966; Morken 1973a, 1973b). The essentially negative character of the biological results shown in these studies suggested that a-irradiation is inefficient in producing radiation-specific tumors in the respiratory system. The only apparent late and permanent changes occurred in the alveolar and respiratory bronchial regions of the lung for a wide range of exposure levels and for observation times of three years in the dog and one and two years in the rat and mouse. Injury was produced in the bronchial tissue, but it was quickly repaired after irradiation ceased.

In the late $1960 \mathrm{~s}$ and early 1970s, France and the U.S. initiated studies in which lung tumors were successfully produced from inhaled radon daughters (Perraud et a1. 1970; Chameaud et al. 1974, 1980; Cross et al. 1978). At an average estimated lung dose of about 3000 rad fror radon daughters, following prior lung stressing with stable cerium, 73 of the rats in the French studies developed malignant tumors (Perraud et a1. 1970). In subsequent French studies, rats exposed either to radon daughters alone or in combination with uranium ore dust and cigarette smoke also produced tumors in the lung (Chameaud et al. 1974, 1980). The U.S. studies were designed to systematicaily determine the pathogenic role of radon daughters, uranium ore dust, diesel engine exhaust fumes, and cigarette smoke, alone or in various combinations. These studies involved life-span exposures of beagle dogs and Syrian golden hamsters (Cross 
et al. 1978). Followup studies are currentiy being conducted with rats. In the 1ater U.S. Studies, tumors also were produced in the respiratory tracts of the animais.

The animal studies have supported the human epidemiology studies. Noted similarities are as follows:

1. Tumor production per WLM at very high exposures is lower than at moderate exposures. This has been tested primarily in rats (Cross et a1. 1980; Chameaud et a1. 1980). The lowest attributable Iung cancer rates per unit exposure were observed in the U.S. uranium miners and Canadian fluorspar miners, where radon daughter levels were the highest of all the underground mines.

2. Tumor production appears to increase with a decrease in exposure rate (Cross et a1. 1980). This is suggested in both the human and animal studies although exposure rate is considered to be of less importance than cumulative exposure.

3. A lower lifetime incidence of lung cancer is observed in dogs exposed to cigarette smoke in succession with radon daughters and uranium ore dust than to radon daughters and uranium ore dust without cigarette smoke (Cross et a). 1978). This effect was also observed in a smal1 group of Swedish zinc-lead miners and is tentatively ascribed to the protective effect of increased mucus production from smoking (Axelson and Sundell 1978) or of the thickened mucosa resulting fram smoker's bronchitis. Tobacco smoke has been found to be cocarcinogenic with radon daughters when given to rats following their cumulative exposure to the daughters (Chameaud et al. 1980). This effect is not observed, however, when smoking precedes the radon daughters (Chameaud et al. 1981). This may partially explain the discrepancies observed in the interpretation of epidemiological data.

4. Emphysema can be attributed to radon daughter exposure in both animals (hamsters, rats, and dogs) and underground miners. The simultaneous presence of ore dust or diesel fumes does not appear to 
increase the number of tumors produced by exposure to radon daughters (Cross et a1. 1978, 1980; Chameaud et aI. 1981).

5. For equal cumulative exposures, the older the age at the start of exposure, the shorter the latency period and, within limits, the higher the associated risk (Chameaud et a1. 1981). In humans, the highest risk coefficient calculated, $50 \times 10^{-6}$ lung cancers per year per WLM, is for persons first exposed later in life (over 40 years of age).

6. The estimates made by the various dosimetric models appear to be borne out in the various species. The tumors induced in experiments with hamsters and rats, which have similar lung morphometry, occur in the distal portion of the conducting airways or in the pulmonary region. These regions receive the highest dose, based on calculations (Desrosiers, Kennedy and Little 1978). Human tumors appear almost exclusive1y in the upper generations of the bronchial tree. Absorbed dose calculations show that basal cells in the upper airways at about the segmental bronchi receive the highest dose from radon daughters (Harley and Pasternack 1972).

7. Lifetime risk coefficients are similar in both the animals and humans. The rat data appear to range between 1 and $4 \times 10^{-4}$ per WLM for all tumors (benign and malignant) at cumulative exposures less than 5000 WLM (Chameaud et aT. 1981). (a) At exposures where lifespan does not appear to be significantly shortened $(<500 \mathrm{WLM})$, the lifetime risk coefficient appears to be about $2 \times 10^{-4}$ per WLM for malignancies and ranges between 2 to $4 \times 10^{-4}$ for all tumors. As yet, data are insufficient to determine the value below 100 WLM exposures.

(a) F. T. Cross, et al. Unpublished data from draft report, An Overview of the PNL Experiments With Reference to Epidemiology Data. Pacific Northwest Laboratory, Richtand, Washington. 


\subsection{REFERENCES}

Alanko, K., H. Keskiner, and L. Saarinen. 1977. "Dccupational Asthma." Duodecim. $93: 306-318$.

Albert, R. E., et al. 1973. "Bronchial Deposition and Clearance of Aerosols." Arch. Intern. Med. 131:115-127.

Altshuler, B., N. Nelson and M. Kuschner. 1964. "Estimation of Lung Tissue Dose from the Inhalation of Radon and Daughters." Health Phys. 10:1137.

Anderson, L. 1979. "Formaldehyde in the Indoor Environment--Health Implications and the Setting of Standards." In Indoor Climate: Effects on Human Comfort, Performance and Health in Residential, Commercial and Light-Industry Buiddings. Proceedings of the First International Indoor Cifimate Symposium, August 30-September 1, 1978, Copenhagen.

Anderson, E. W., et al. 1973. "Effect of Low-Level Carbon Monoxide Exposur? on Onset and Duration of Angina Pectoris: A Study on 10 Patients with Ischemic Heart Disease." Ann Intern. Hed. 79:46-50.

Archer, V. E. 1978. "Summary of Data on Uranium Miners." In Workshop on Dosimetry for Radon and Radon Daughters. ORNL-5348, Oak Ridge National Laboratory, 0ak Ridge, Tennessee.

Archer, V. E., E. P. Radford and 0. Axelson. 1979. "Radon Daughter Cancer in Man: Factors in Exposure Response Relationship." In Conference Workshop on Lung Cancer Epidemiology and Industrial Applications of Sputum Cytology. Colorado School of Mines Press, Golden, Colorado.

Aronow, W. S., E. A. Stemmer, and M. W. Isbel1. 1974. "Effect of Carbon Monoxide Exposure on Intermittent Claudication. Circulation. 49:415-417.

Axelson, 0. and C. Edding. 1980. "Health Hazards from Radon Daughters in Sweden." In Heaith Implications of New Energy Technologies, Proceedings of an Environmental Health Conference, Aprit 4-7, 1979, Washington, D.C.

Axelson, 0. and L. Sundell. 1978. "Mining Lung Cancer and Smoking." Scand. J. Work Environ. and Health. $4: 46$.

Bale, W. F., and J. V. Shapiro. 1956. "Radiation Dosage to Lungs from Radinn and Its Daughter Products." In Proceedings U.N. International 1975 Confenence on Peaceful Uses of Atomic Energy. United Nations Publications, New York, New York.

Bei1, M., and W. T. UTmer. 1976. "Effect of $\mathrm{NO}_{2}$ in Workroom Concentrations on Respiratory Mechanics and Bronchial Susceptibitity to Acetylcholine in Normal Persons" (German). Int. Arch. Occup. Environ. Health. 38:31-44. 
Bender, W., et a]. 1971. "Effects of Low Carbon Monoxide Concentrations in Man." Arch. Toxicol. 27:142-158.

Benignus, V. A., et al. 1977. "Effects of Low Carbon Monoxide Concentrations on Human Vigilance." Percept. Mot. Skills. 45:1007-1014.

Biller, W. F., and H. M. Richmond. 1982. Sensitivity Anaiysis on Coburn Model Predictions on $\mathrm{COHb}$ Levels Associated with ATternative CO Standards. Prepared for the U.S. Environmental Protection Agency, Research Triangle Park, North Carolina.

Bouhuys, A. 1977. The Physiology of Breathing: A Textbook for Medical Students. Grume and Stratton, New York, New York.

Bouhuys, A., G. J. Beck and J. B. Schoenberg. 1978. "Do Present Levels of Air Pollution Outdoors Affect Respiratory Hea1th?" Nature. 276:466-471.

Boushey, H. A., et al. 1980. "Bronchial Hyperreactivity." An. Rev. Resp. Dis. 121:389-413.

Breysse, P. A. 1977. "Formaldehyde in Mobile and Conventional Homes." Environ. Health Safety News. 26:1-20.

Burgess, W., L. Di Berardinis and F. E. Speizer. 1973. "Exposure to Automobile Exhaust - III. An Environmental Assessment." Arch. Environ. Health. 26: 325-329.

Chameaud, J., et al. 1974. "Lesions and Lung Cancers Induced in Rats by Inhaled Radon-222 at Various Equilibriums with Radon Daughters." In Experimental Lung Cancer. Carcinogenes is and Bioassays, E. Karbe and J. Park, eds., Springer-Verlag, New York, New York.

Chameaud, J., et aT. 1980. "Combined Effects of Inhalation of Radon Daughter Products and Tobacco Smoke." In Pulmonary Toxicology of Respirable Particles, C. L. Sanders et a1., eds., CONF-791002, National Technical Information Service, Springfield, Virginia.

Chameaud, J., et al. 1981. "Contribution of Animal Experimentation to the Interpretation of Human Epidemioiogical Data." In Proceedings of International Conference Radiation Hazards in Mining: Control, Measurement, and Medical Aspects, October 4-9, 1981, Colorado School of Mines Press, Golden, Colorado.

Christensen, C. L., et al. 1977. "Effects of Three Kinds of Hypoxias on Vigilance Performance." Av. Sp. Env. Med. 48:491-496.

Coburn, R. F., W. S. Blackemore and R. E. Forster. 1963. "Endogenous Carbon Monoxide Production in Man." J. Clin. Invest. 42:1172-1178. 
Coburn, R. F*, R. E. Forster, and P. B. Kane. 1965. "Considerations of the Physiological Variables that Determine the Blood Carboxyhemogloben Concentration in Man." J.Clin. Invest. 44:1899-1910.

Cohen, C. A., et al. 1972. "Respiratory Symptoms, Spirometry, and Oxidant A. $r$ Pollution in Nonsmoking Adults." Amer. Rev. Resp. Disease. 105:251-261.

Cohn, S. H., R. K. Skow and J. K. Gong. 1953. "Radon Inhalation Studies in Rats." Arch. Ind. Hyg. Occup. Med. 7. 508.

Colley, J. R. T., J. W. B. Douglas, and D. D. Reid. 1973. "Respiratory Disease in Young Adults: Influence of Early Childhood Lower Respiratory Tract Illness, Social Class, Air Pollution, and Smoking." Br. Med. J. 3:195-198.

Cote, W. A., W. A. Wade and J. E. Yocom. 1974. A Study of Indoor Air Quality. U.S. Environmental Protection Agency, Washington, D.C.

Cotes, J. E. 1979. Lung Function Assessment and Application in Medicine. Blackwell Scient if ic Publications, London, England.

Cross, F. T., et al. 1978. Study of the Combined Effects of Smoking and Inlialation of Uranium Ore Dust, Radon Daughters and Diesel 011 Exhaust Fumes in Hamsters and Dogs. Pacific Northwest Laboratory, PNL-2744, Available from the National Technical Information Service, Springfield, Virginia.

Cross, F. T., et al. 1980. "Influence of Radon Daughter Exposure Rate and Uranium Ore Dust Concentrations on Occurrence of Lung Tumors." In Proceedings of Specialist Meeting on Assessment of Radon and Daughter Exposure and Related Biological Effects, March 3-7, 1980, CNEN, Rome.

Desrosiers, A. E., A. Kennedy and J. B. Little. 1978. "222 Rn Daughter Dosimetry in the Syrian Golden Hamster Lung." Health Phys. 35:607.

Devilitiers, A. J., and J. P. Windish. 1964. "Lung Cancer in a Fluorspar Mining Community: I. Radiation, Dust and Mortality Experience." Br. J. Ind. Med. 21:94.

Do11, R. 1978. "Atmospheric Pollution and Lung Cancer." Environ. Health Perspect. 22:23-31.

Douglas, J. W. B., and R. E. Waller. 1966. "Air Pollution and Respiratory Infection in Children." Br. J. Prev. Soc. Med. 20:1-8.

Orinkwater, B. L., et a1. 1974. "Air Pollution, Exercise, and Heat Stress." Arch. Environ. Health. 28:177-181.

Eisen, H. N. 1976. "Chronic Cough in Young Adults in Relation to Smoking Habits, Chitdhood Environment and Chest Iliness." Respiration. 33:236-244.

Eisen, H. N. 1976. Immunology. Harper and Row, Hagerstown, Maryland. 
Ekblom, B., and R. Huot, 1972. "Response to Submaximal and Maximal Exercise at Different Levels of Carboxyhemogloben." Acta Physiol. Scand. 86:474-482.

Evans, R. D. 1967. "On the Carcinogenicity of Inhaled Radon Decay Products in Man (CORD)." Report Submitted Before the Joint Committee on Atomic Energy, Subcommittee on Research, Development and Radiation, July 1967: Hearings on Radiation Exposure of Uranium Miners, Part 2, p. 1188. Government Printing office, Washington, D.C.

Evans, R. D., et a1. 1981. "Estimate of Risk from Environmental Exposure to Radon-222 and Its Decay Products." Nature. 290:98.

Federal Radiation Council. 1967. Guidance for the Control of Radiation Hazards in Uranium Mining. Federal Radiation Council Staff Report No. 8 (revised), U. S. Government Printing Office, Washington, D.C.

Feldman, Y. U. G. and T. I. Bonashevskaya. 1971. "On the Effects of Low Concentrations of Formaldehyde." Gig. Sanit. 36:174-180.

Ferris, B. G., et al. 1973. "Chronic Non-Specific Respiratory Disease in Bertin, New Hampshire, 1967-1973 - A Follow-Up Study." Am. Rev. Respir. Dis. 107:110-122.

Ferris, B. G., et al. 1976. "Chronic Non-Specific Respiratory Disease in Berlin, New Hampshire, 1967-1973 - A Further Follow-Up Study." Am. Rev. Respir. Dis. 113:475-485.

Florey, C. duv., et a1. 1979. "The Relation Between Respiratory Iliness in Primary Schoolchildren and the Use of Gas for Cooking. III - Nitrogen Dioxide, Respiratory Illness and Lung Infection." Int. J. Epid. 8:347.

Fodor, G. G., and G. Winneke. 1972. "Effect of Low CO Concentrations on Resistance to Monotony and on Psychomotor Capacity" (German). Stalib Reinhalt. Luft. 32:45-54.

Fry, R. M. 1977. "Radon and Its Hazards." In Proceedings of NEA Specialist Meeting, Personal Dosimetry and Area Monitoring Suitabie for Radon and Daughter Products. Nuclear Energy Agency, OECD, Paris, France.

Goldstein, B. D., et al. 1979. "The Relation Between Respiratory IIIness in Primary Schooichildren and the Use of Gas for Cooking. II - Factors Affecting Nitrogen Dioxide Levels in the Home." Int. J. of Epid. 8:339.

Greenburg, L., et a1. 1962. "Air Pollution and Morbidity in New York." JAMA. 182:161-164.

Greisemer, R. A., et al. 1980. Report of the Federal Panel on Formaldehyde. Consumer Product Safety Commission and National Toxicology Program, Washington, D.C. 
Groll-Knapp, E., et al. 1972. "Effects of Low Carbon Monoxide Concentration:s on Vigilance and Computer-Analyzed Brain Potentials" (German). Staub Reinhalt. Luft. 32:64-68.

Gupta, K. C., A. G. U1samer and P. W. Preuss. 1982. "Formaldehyde in Indoor Air: Sources and Toxicity." Environment International. 8:349-358.

Hackney, J. D., et al. 1975. "Experimental Studies on Human Health Effects of Air Pollutants. II - Four Hour Exposure to Ozone Alone and In Combination with Other Pollutant Gases." Arch. Environ. Health. 30:379-384.

Haider, M., et a1. 1976. "Effects of Moderate CO Dose on the Central Nervous System--Electrophysiological and Behaviour Data and Clinical Reference." In Clinical Implications of Air Pollution Research. A. J. Finkel and W. C. Duel, eds., Publishing Sciences Group, Inc., Acton, Massachusetts.

Haque, A. K. M. M. 1966. "Energy Expended by Alpha Particles in Lung Tissue." Br. J. Appl. Phys. 17:905.

Haque, A. K. M. M. 1967. "Energy Expended by Alpha Particles in Lung Tissue. III. A Computer Method of Calculation." Br. J.Appl. Phys. 18:657.

Haque, A. K. M. H., and A. J. L. Collinson. 1967. "Radiation Dose to the Respiratory System Due to Radon and Its Daughter Products." Health Phys. $13: 431$.

Harley, J. H. 1953. "Sampling and Measurement of Air-Borne Daughter Products of Radon." Nucleonics. 11:12.

Harley, N. H., and B. S. Pasternack. 1972. "Alpha Absorption Measurements Applied to Lung Dose from Radon Daughters." Health Phys. 23:771.

Harley, N. H., and B. S. Pasternack. 1981. "A Model for Predicting Lung Cancer Risks Induced by Environmental Levels of Radon Daughters." Health Phys. 40:307.

Harris, S. J. 1954. "Radon Exposures in Various Mines." Paper presented to the Ind. Health Conf., April 28, 1954, Chicago, Illinois.

Hawthorne, A. R., and T. G. Matthews. 1985. "Formaldehyde: An Important Indoor Pollutant." In Proceedings: Indoor Air Quality Seminar-Implications for Electric Utility Conservation Programs. EPRI EA/EM-3824, W. I. Whiddon and Associates, McLean, Virginia.

Hendrick, D. J., and D. J. Lane. 1977. "Occupational Formalin Asthma." Br. J. Ind. Med. 34:11-18.

Hewitt, D. 1979. "Biostatistical Studies on Canadian Uranium Miners." In Conference/Workshop on Lung Cancer Epidemiology and Industrial Applications on Sputum Cytology. Colorado School of Mines Press, Golden, Colorado. 
Hofmann, W. 1982. "Dose Calculations for the Respiratory Tract from Inhaled Natural Radioactive Nuclides as a Function of Age - II. Basal Cell Dose Distributions and Associated Lung Cancer Risk." Health Phys.

Horsfall, F. L. 1934. "Formaldehyde Hypersensitiveness-An Experimental Study." J. Immunol. $27: 569-581$.

Horvath, S. M., T. E. Dahms and J.F. O'Hanion. 1971. "Carbon Monoxide and Human Vigilance: A Deleterious Effect of Present Urban Concentrations." Arch. Environ. Hea 1th. 23:343-347.

Horvath, S. M., and L. J. Folinspee. 1979. Effects of Pollutants on Cardiopulmonary Function. U.S. Environmental Protection Agency, Research Triangle Park, North Carolina.

Horvath, S. M., et al. 1975. "Maximal Aerobic Capacity at Different Levels of Carboxyhemogloben." J.App?. Physiol. 38:300-303.

Horvath, S. M., et al. 1983. "Letter to Dr. Lester D. Grant, Including the Peer-Review Committee Report on Dr. Aronow's Studies." Docket No. OAQPS 79-7, IV-H-58, Available frora U.S. Environmental Protection Agency, Central Docket Section, Washington, D.C.

Hovding, G. 1969. "Occupational Dermatitis from Pyrolysis Products of Polythene." Acta Derm. Venereol. 49:147-149.

Huech, W. 1939. "Kurzer Bericht uber Ergebnisse Anatomischer Untersuchungen in Schneeberg." Z. Krebsforschung. 49:312.

International Commission on Radiological Protection. 1977. Radiation Protection in Uranium and Other Mines. International Commission on Radiological Protection, ICRP Pubjication 24, Pergamon Press, New York, New York.

International Commission on Radiological Protection. 1981. Limits for Inhalation of Radon-222, Radon-220 and Their Short-Lived Daughters. International Commission on Radiological Protection, ICRP Publication, Pergamon Press, New York, New York.

Jackson, M. L. 1940. The Biological Effects of Inhaled Radon. Master's Thesis, Massachusetts Institute of Technology, Cambridge, Massachusetts.

Jacobi, W. 1964, "The Dose to the Human Respiratory Tract by Inhaiation of

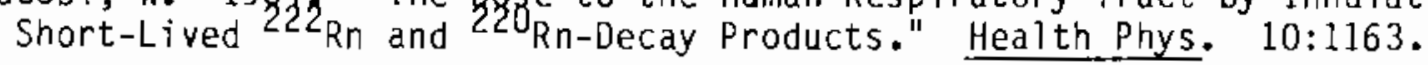

Jacobi 96. 1972. "Relations Between the Inhaled Potential a-Energy of ${ }^{222} \mathrm{Rn}$ and 222 Rn-Daughters and the Absorbed $\alpha$-Energy in the Bronchial and Pulmonary Region." Health Phys. 23:3. 
Jacobi, W. 1977. "Interpretation of Measurements in Uranium Mines: Dose Evaluation and Bionedical Aspects." In Proceedings of NEA Specialist Meeting, Personal Dosimetry and Area Monitoring Suitable for Radon and Daughter Products. Nuclear Energy Agency, OECD, Paris, France.

Jacobi, W., and K. Eisfeld. 1980. Dose to Tissues and Effective Dose Equiva-. lent by Inhalation of Radon-222, Radon-220 and Their Short-Lived Daughters. Gesellschaft fur Strahlen-und Úmweltforschung MBH, Report GSF S-626, Institute fur Strahlenschutz, Munich-Neuherberg, Germany.

James, A. C., J. R. Greenhalgh and A. Birchall. 1980. "A Dosimetric Model for Tissues of the Human Respiratory Tract at Risk from Inhaled Radon and Thoror Daughters." In Radiation Protection. A Systematic Approach to Safety, Vol. 2, Proc. 5th Congress IRPA, March 1980, Jerusalem, Pergamon Press, oxford.

James, A. C., W. Jacobi and F. Steinhausler. 1981. "Respiratory Tract Dosimetry of Radon and Thoron Daughters: The State-of-the-Art and Implications for Epidemiology and Radiobiology." In Proceedings of International Conference Radiation Hazards in Mining: Control, Measurement, and Medical Aspects, October 4-9, 1981, Colorado School of Mines, Golden, Colorado.

Jansen, $H_{.}$, and P. Schultzer. 1926. "Experimental Investigations into the Internal Radium Emanation Therapy - I. Emanatorium Experiments with Rats." Acta Radiol. 6:631.

Joint Committee on Atomic Energy. 1967. Hearings on Radiation Exposure of Uranium lliners. Joint Committee on Atomic Energy, Subcommittee of Research Development and Radiation, Congress of the United States, Ninetieth Congress, May-August 1967, Government Printing Office, Washington, D.C.

Joint Committee on Atomic Energy. 1969. Hearings on Radiation Exposure of Uranium Miners. Joint Committee on Atomic Energy, Subcommittee of Research Development and Radiation, Congress of the United States, Ninety-First Congress, March 17 and 18, 1969, Government Printing Office, Washington, D.C.

Jorgensen, H. S. 1973. "A Study of Mortality from Lung Cancer Among Mliners in Kiruna, 1950-1970." Work Environment Health. 10:126.

Kagawa, J., and T. Toyama. 1975. "Photochemical Air Pollution: Its Effects on Respiratory Function of Elementary School Children." Arch. Environ. Hea 1th. 30:117-122.

Keller, M. D., et al. 1979. "Respiratory Illness in Households Using Gas anc Electric Cooling." Environ. Res. 19:495-515.

Kerr, H. D., et al. 1979. "Effect of Nitrogen Dioxide on Pulmonary Function in Human Subjects: An Environnental Chamber Study." Environ. Res.

19:392-404. 
Kiernan, K. E., et al. 1976. "Chronic Cough in Young Adults in Relation to Smoking Habits, Childhood Environment and Chest Iliness." Respiration. $33: 236-244$.

Klein, J. P., et al. 1980. "Hemoglobin Affinity for Oxygen During Short-Term Exhaustive Exercise." J.App1. Physiol. 48:236-242.

Kushneva, V. S. 1959. "On the Problem of the Long-Term Effects of Combined Injury to Animals of Silicon Dioxide and Radon." AEC-TR4473, Atomic Energy Commission, Washington, D.C.

Lambert, P. M., and D. D. Reid. 1970. "Smoking, Air Pollution and Bronchitis in Britain." Lancet. I:853-857.

Lawther, P. J., R. E. Waller and M. Henderson. 1970. "Air Pollution and Exacerbations of Bronchitis." Thorax. 25:525-539.

Lebowitz, M. D., E. J. Cassell, and J. R. McCarroll. 1972. "Health and the Urban Environment. XV. Acute Respiratory Episodes as Reactions by Sensitive Individuals to Air Pollution and Weather." Environ. Res. 5:135-141.

Linn, W. S., et al. 1976. "Respiratory Functions and Symptoms in Urban Office Workers in Relation to 0xidant Air Pollution Exposure." Amer. Rev. Resp. Dis. 114:477-483.

Longo, L. D. 1977. "The Biological Effects of Carbon Monoxide on the Pregnant Woman, Fetus, and Newborn Infant." Am. J. Dbstet. Gynecol. 129:69-103.

Lunn, J. E., J. Knowelden and A. J. Handyside. 1967. "Patterns of Respiratory Illness in Sheffield Infant Schoolchildren." Br.. J. Prev. Soc. Med. $21: 7-16$.

Martin, A. E. 1964. "Mortality and Morbidity Statistics and Air Pollution." Proc. R. Soc. Med. 57:969-975.

Martin, A. E., and W. H. Bradley. 1960. "Mortality, Fog and Atmospheric Pollution - An Investigation During the Winter of 1958-59. Mon. Bull. Minist. Health Lab. Serv. 19:56-73.

Mazundar, S., H. Schimmel and I. Higgins. 1981. Daily Mortality, Smoke and $\mathrm{SO}_{2}$ in London, England 1959-1972. Proceedings of the Proposed $\mathrm{SO}_{x}$ and Particulate Standard Speciality Conference. Air Pollution Control Association, Atlanta, Georgia.

McCuliough, R., H. Stocker and C. E. Makepeace. 1979. "Pilot Study on Radon Daughter Exposures in Canada." In Conference/Workshop on Lung Cancer Epidemiology and Industrial Applications of Sputum Cytology. Colorado School of Mines Press, Gotden, CoTorado.

McFarland, R. A. 1973. "Low Level Exposure to Carbon Monoxide and Driving Performance." Arch. Environ. Health. 27:355-359. 
HCFarland, R. A., et a1. 1944. "The Effects of Carbon Monoxide and Attitude on Visual Thresholds." J.Aviat. Med. 15:381-394.

îcPherson, R. B. 1979. Environmental Radon and Radon Daughter Dosimetry in the Respiratory Tract. PNL-2898, Pacific Northwest Laboratory, Available from the National Technical Information Service, Springfield, Virginia.

Melekhina, V. P. 1964. "Maximum Permissible Concentration of Formaldehyde in Atmospheric Air." USSR Lit. Air Pollu. El. Occup. Dis. 3:135.

Melia, R. J. W., C. du V. Florey and S. Chinn. 1979. "The Relation Between Respiratory Illness in Primary Schoolchildren and the Use of Gas for Cooking I - Results from a National Survey." Int. J. Epid. 8:333.

Melia, R. J. W., et al. 1977. "Association Between Gas Cooling and Respiratory Disease in Children." Brit. Med. J. 2:149-152.

Menzel, D. B. 1980. "Pharmacological Mechanisms in the Toxicity of Nitrogen Dioxide and Its Relation to Obstructive Respiratory Disease." In Nitrogen oxides and Their Effect on Health, Lee, S. D. (ed), Ann Arbor Science, Ann Arbor, Michigan.

Ministry of Hea]th. 1954. "Mortality and Morbidity During the London Fog of December 1952." Ministry of Health, London, England.

Mitchel?, R. I., et al. 1974. "Household Survey of the Incidence of Respiratory Disease in Relation to Environmental Pollutants." In Recent Advance in the Assessment of the Health Effects of Environmental PolTutants, World Health Organization International Symposium Proceedings, Paris, June $24-28,1974$.

Morgan, W. K. L. 1978. "Industrial Bronchitis." Br. J. Ind. Med. $35: 285-291$.

Morken, D. A. 1955. "Acute Toxicity of Radon." AMA Arch. Ind. Health. $12: 435$.

Morken, D. A. 1973a. "The Biological Effects of the Radioactive Noble Gases." In Noble Gases, R. E. Stanley and A. A. Moghissi, eds. National Environmenta] Research Center, Report CONF-730915, National Environtnental Research Center, Las Vegas, Nevada.

Morken, D. A. 1973b. "The Biological Effects of Radon on the Lung." In Noble Gases, R. E. Stanley and A. A. Moghissi, eds. National Environmental Research Center, Report CONF-730915, National Environmental Research Center, Las Vegas, Nevada. 
Morken, D. A., and J. S. Scott. 1966. Effects on Mice of Cont inual Exposure to Radon and Its Decay Products on Dust. University of Rochester Atomic Energy Project, Report UR-659, National Technical Information Service, Springfield, Virginia.

National Academy of Sciences (NAS). 1972. The Effects on Populations of Exposure to Low Levels of Ionizing Radiation (BEIR Report). National Academy of Sciences, Government Printing Office, Washington, D.C.

National Academy of Sciences (NAS). 1980. The Effects on Populations of Exposure to Low Levels of Ionizing Radiation (BEIR-III Report). Nationa 1 Acadeny Press, Nationa 1 Academy of Science, Washington, D.C.

National Acadeny of Sciences (NAS), Committee on Aldehydes, 1981. Formaldehyde and Other Aldehydes. National Academy Press, Washington, D.C.

Nationa) Academy of Sciences (NAS), Committee on Toxicology. 1980. Formal dehyde--An Assessment of Its Health Effects. National Academy Press, Washington, D.C.

National Institute for Occupational Safety and Health (NIOSH). 1976. "Revised Recommended Standard: Exposure to Asbestos." U.S. Department of Health and Human Services, Washington, D.C.

National Institute for Occupational Safety and Health/National Institute of Environmental Health Sciences (NIOSH/NIEHS). 1971. Radon Daughter Exposure and Respiratory Cancer - Quantitative and Temporal Aspects. NIOSH/NIEHS, Joint Monograph No. 1, National Technical Information Service, Springfield, Virginia.

Nelson, 1. C., et al. 1974. A Further Appraisal of Dosimetry Related to Uranium Mining Health Hazards, J.S. Public HeaTth Service Report, CPE $69-$ 1131, National Institute for Occupational Safety and Health, Cincinnati, ohio.

Niinimaa, V., et al. 1981. "Oralnasal Distribution of Respiratory Airflow." Resp. Physiol. 43:69-75.

0'Donne11, R. D., et al. 1971. "Low-Level Carbon Monoxide Exposure and Human Psychomotor Performance." Toxicol. Appl. Pharma-Col. 18:593-602.

Orehek, J., et al. 1976. "Effect of Short-Term, Low-Leve? Nitrogen Dioxide Exposure on Bronchial Sensitivity of Asthmatic Patients." J. Clin. Invest. $57: 301-307$.

Parker, H. M. 1969. "The Dilemra of Lung Dosimetry." Health Phys. 16:558.

Pearlman, M. G., et al. 1971. "Nitrogen Dioxide and Lower Respiratory Illness." Pediatrics. 47(2):391-398. 
Perraud, R., et a1. 1970. "Cancer Pulmonaires Experimentaux Chez le Rat apres inhalation de Radon associe a des Poussieres non Radioactives" (French). Compt. Rend. Ser. D. 270:2594.

Pirila, V., and 0. Kilpio. 1949. "On Dermatitis Caused by Formaldehyde and Its Compounds." An. Med. Intern. (Fenn.). 38:38-51.

Pirnay, F., et al. 1971. "Muscular Exercise During Intoxication by Carbon Monoxide." J. App1. Physiol. 31:573-575.

Popa, V., D. Teculescu and D. Stanescu. 1969. "Bronchial Asthma and Asthmatic Bronchitis Determined by Simple Chemicals." Dis. Chest. 56:395-404.

Posin, C., et al. Nov./Dec. 1978. "Nitrogen Dioxide and Human Blood Biochemistry." Arch. Environ. Health. pp. 318-324.

Putz, V. R. 1979. "The Effects of Carbon Monoxide on Dual-Task Performance." Human Factors. 21:13-24.

Putz, V.R., B. L. Johnson, and J.V. Setzer. 1976. Effects of Co on Vigilance Performance. Effects of Low-Level Carbon Monoxide on Divided Attention, Pitch Discrimination, and the Auditory Evoked Potential. DHEW No. 77-124, U.S. Department of Hea7th, Education and Welfare, National Institute of 0ccupationa? Safety and Health, Cincinnati, Ohio.

Putz, V. R., B. L. Johnson and J. V. Setzer. 1979. "A Comparative Study of the Effects of Carbon Monoxide and Methylene Chioride on Human Performance." In Proceedings of 1st Annual NIOSH Scient ific Symposium Pathotox Publishing Company, Chicago, ITTinois.

Rader, J. 1974. "Irritant Effects of Formaldehyde in Anatomy Laboratories: Analytical and Experimental Investigations." Doctoral Dissertation, University of Wurzburg.

Radford, E. P. 1981a. "Lung Cancer Risk from Radon Daughters, and the Problem of Appropriate Standards of Exposure in Underground Mines." In Proceedings of International Conference on Radiation Hazards in Mining: Control, Measurement and Medical Aspects, October 4-9, 1981, Colorado School of Mines Press, Golden, Colorado.

Radford, E. P. 1981b. "Radon Daughters in the Induction of Lung Cancer in Underground Miners." Banbury Conference Proceedings.

Rajewsky, B., A. Schraub and E. Schraub. 1942a. "Uber die toxische Dosis by Einatmung von Ra-Emanation." Naturwissenschaften. 30:489.

Rajewsky, B., A. Schraub and E. Schraub. 1942b. "Zur Frage der Toleranz-Dosis bei der Einatmung von Ra-Em." Naturwissenschaften. 30:733. 
Raven, P. B., et al. 1974. "Age, Smoking Habits, Heat Stress, and Their Interactive Effects with Carbon Monoxide and Peroxyacetylnitrate on Man's Aerobic Power." Int. J. Biometeriol. 18:222-232.

Read, J., and J. C. Mottram. 1939. "The 'Tolerance Concentration' of Radon in the Atmosphere." Br. J. Radiol. 12:54.

Redmond, C. K., B. R. Strobino and R. H. Cypess. 1976. "Cancer Experience Among Coke By-Product Workers." Ann. N. Y. Acad. Sci. 271:102-115.

Renard, K. G. 1974. "Respiratory Cancer Mortality in an Iron Mine in Northern Sweden." Ambia. 3:67.

Rockwell, T. J., and F. W. Weir. 1975. The Interactive Effects of Carbon Monoxide and Alcohol on Driving Skills. Ohio State University Research Foundation, Columbus, Ohio.

Rummo, N., and K. Sarlanis. 1974. "The Effect of Carbon Monoxide on Several Measures of Vigilance in a Simulated Driving Task." J. Saf. Res. 6:126-130.

Saibene, F., et al. 1978. "Dronasal Breathing During Exercise." Pfuegers Arch. 378:65-69.

Salvatore, S. 1974. "Performance Decrement Caused by Mild Carbon Monoxide Levels on Two Visual Functions." J. Saf. Res. 6:131-134.

Schlipkoter, H. W. and A. Brockhaus. 1963. "Versuche uber den Einfluss gasformiger Luftverunreinigungen auf die Deposition and elimation inhalierter Staub. Zentralb. Bakteriol. Parasitenkd. Infektionskr (German)." Hyg. Abt. 1. 191:339-344.

Schuck, E. A., E. T. Stephens and J. T. Middleton. 1966. "Eye Irritation Response at Low Concentrations of Irritants." Arch. Environ. Health. $13: 570$.

Schulte, J. W. 1973. "Effects of Mild Carbon Monoxide Intoxication." Arch. Environ. HeaTth. 7:524-530.

Sevc, J., E. Kunz and V. Placek. 1976. "Lung Cancer in Uranium Miners and Long Term Exposure to Radon Daughter Products." Health Phys. 30:433.

Seven State Uranium Mining Conference. 1955. In Proceedings of Uranium Mining Conference on Health Hazards. Hotel Utah, Salt Lake City, Utah.

Sgibnev, A. K. 1968. "Effect of Formaldehyde Fume Concentrations on Humans." Gig. Tr. Prof. Zabol. 12:20.

Shapiro, J. 1954. An Evaluation of the Pulmonary Radiation Dosage from Radon and its Daughter Products. Report UR-298, University of Rochester Atomic Energy Project, Rochester, New York. 
Shellow, N., and A. T. Altman. 1966. "Dermatit is From Formaldehyde Resin Textiles." Arch. Dermatol. 94:799-801.

Shy, C. M., and G. J. Love. 1979. Recent Evidence on the Human Health Effects of Nitrogen Dioxide. Proceedings of the Symposium on Nitrogen Oxides, Honolulu, Hawaii, April 4-5, 1979.

Shy, C. M., et al. 1970a. "The Chattanooga School Children Study: Effects cf Community Exposure of Nitrogen Dioxide. I. Methods, Description of Pollutant Exposure and Results of Ventilatory Function Testing." J.Air Pollutant Control Assoc. 20(8):539-545.

Shy, C. M., et al. 1970b. "The Chattanooga School Study: Effects of Community Exposure to Nitrogen Dioxide. II. Incidence of Acute Respiratory IlIness." J. Air. Pollutant Control Assoc. 20(8):582-588.

Skogh, M. 1959. "Axillary Eczema in Women, a Syndrome." Acta Derm. Venereol. 39:369-371.

Snihs, J. 0. 1973. "The Significance of Radon and its Progeny as Natural Radiation Sources in Sweden." In Noble Gases, R. E. Stanley and A. A. Moghissi, eds. Report CONF-730915, National Environmental Research Center, Las Vegas, Nevada.

Snihs, J. 0. 1974. "The Approach to Radon Problems in Non-Uranium Mines in Sweden." In Proceedings of the Third International Congress of the International Radiation Protection Association, U. S. Atomic Energy Commission, Report CONF-730907, National Technical Information Service, Springfield, Virginia.

Speizer, F. E., and B. G. Ferris, Jr. 1973. "Exposure to Automobile Exhaust. I. Prevalence of Respiratory Symptoms and Disease." Arch/EnviroriHealth. 26:313-318.

Speizer, F. E., et al. 1980. "Respiratory Disease Rates and Pulmonary Function in Children Associated with $\mathrm{NO}_{2}$ Exposure." An. Rev. Resp. Dis. $121: 3-10$.

Stewart, R. D., et a1. 1978. Effect of a Rapid 4 Percent Carboxyhemog Joben Saturation Increase on MaximaT Treadnil] Exercise. CRC-APRAC-CAPM-22-75.

Stranden, E. 1980. "Radon in Swellings and Lung Cancer. A Discussion." Health Phys. 38:301.

U.S. Department of Commerce (DOC). 1980. Statistical Abstract of the United States, 1980 (101st Edition). Bureau of Census, Washington, D.C.

U.S. Department of Health, Education and Welfare (DHEW). 1973. Prevalence of Selected Chronic Respiratory Conditions, United States - 1970. Publication No. (HRA) 75-1511, Series 10, Number 84, DHEW, Rockville, Maryland. 
U.S. Department of Health, Education and Welfare (DHEW). 1974. Prevalence of Chronic Respiratory Conditions, United States - 1972. DHEW Publication No. (HRA) 75-1521, Rockville, Maryland.

U.S. Department of Health, Education and Welfare (DHEW). 1975. Coronary Heart Diseases in Adults: United States, 1960-1962. DHEW Publication No. (PHS) 79-1919, Publication Heatth Service, Hyattsville, Maryland.

U.S. Department of Health, Education and Welfare (DHEW). 1977. The Smoking Digest. Public Health Service, National Institute of Health, National Cancer Institute, Bethesda, Maryland.

U.S. Oepartment of Health, Education and Welfare (DHEW). 1978. Vital Statistics of the United States, 1975, Volume I. DHEW Publication No. (PHS) 78-1113, Pubilic Health Service, Hyattsville, Maryland.

U.S. Environmental Protection Agency (EPA). 1979. Air Quality Criteria for Carbon Monoxide. U.S. Environmental Protection Agency, Research Triangle Park, North Carolina.

U.S. Environmental Protection Agency (EPA). 1982. "Review of the National Ambient Air Quality Standards for Particulate Matter: Assessment of Scientific and Technical Information." Office of Air Quality Planning and Standards, U.S. Environmenta? Protection Agency, Research Triangle Park, North Carolina.

U.S. Environmental Protection Agency (EPA). 1984. "Review of the NAAQS for Carbon Monoxide: Reassessment of Scientific and Technical Information". Staff Paper, U.S. Environmental Protection Agency, Research Triangie Park, North Carolina.

United Nations Scientific Committee on the Effects of Atomic Radiation (UNSCEAR). 1972. Ionizing Radiation: Levels and Effects. United Nations, New York, New York.

United Nations Scientific Committee on the Effects of Atomic Radiation (UNSCEAR). 1977. Sources and Effects of Ionizing Radiation. United Nations, New York, New York.

United States Public Health Service. 1957. Control of Radon and Daughters in Uranium Mines and Calculations on Biologic Effects. United States Public Health Service, Pub, 494, Government Printing Office, Washington, D.C.

United States Public Health Service. 1961. Governor's Conference on Health Hazards in Uranium Mines. A Summary Report, USPHS Publications No. 843, Public Health Service, Bureau of State Services, Washington, D.C.

Utell, M. J., et al. 1980. "Development of Airway Reactivity to Nitrates in Subjects with Influenza." Am. Rev. Respir. Dis. 121:233-241. 
Utel1, M. J., P. E. Morrow and R. W. Hyde. 1981. "Comparison of Normal and Asthmatic Subjects Responses to Sulfate Pollutant Aerosols." Inhaled Particles $V$.

Voge1, J. A., and M. A. Gleser. 1972. "Effects of Carbon Monoxide on Oxygen Transport During Exercise." J.Appl. Physiol. 32:234-239.

Von Nieding, G., et a1. 1971. "Minimum Concentrations of $\mathrm{NO}_{2}$ Causing Acute Effects on the Respiratory Gas Exchange and Airway Resistance in Patients with Chronic Bronchitis." Translated from German by Mundus Systems for Air Pollution Technical Information Center, U.S. Environmental Protection Agency, Research Triangle Park, North Carolina.

Von Nieding, G., et al. 1973. "Minimum Concentrations of $\mathrm{NO}_{2}$ Causing Acute Effects on the Respiratory Gas Exchange and Airway Resistance in Patients with Chronic Bronchitis." int. Arch. Arbeitsmed. 27:338-348. Transiated from German by Mundus Systems for Air PoTlution Technical Information Center, U.S. Environment Protection Agency, Research Triangle Park, North Carolina.

Von Nieding, G., et a). 1977. "Acute Effects of 0zone on Lung Functions of Man." VDi-Ber. 270:123-129.

Wagoner, J. K., et a1. 1964. "Cancer Mortality Patterns Among U.S. Uranium Miners and Millers, 1950 through 1962." J. Natl. Cancer Inst. 32:787.

Wahren, H. 1980. "Swedish Indoor Air Standards." Presentation at U.S. CPSC technical Workshop on Formaldehyde.

WaIsh, P.J. 1970. "Radiation Dose to the Respiratory Tract of Uranium Miners." Environ. Res. 3:14.

Walsh, P. J. 1971. "Relationship of Experimental to Empirical Findings and Theoretical Dose Calculations." Final Report of Subgroup IB, Interagency Uranium Mining Radiation Review Group. Environmental Protection Agency, Rockville, Maryland.

Walsh, P. J. 1979. "Dose Conversion Factors for Radon Daughters." Health Phys. $36: 601$.

Ware, J., et al. 1981. "Assessment of the Health Effects of Sulfur Oxides and Particulate Matter: Analysis of the Exposure-Response Relationship." Env. Health Persp.

Weber-Tschop, A., T. Fischer and E. Grandjean. 1977. "Reizwickungen des Formaldehyds (HCHO) auf den Menschen." Int. Arch. Occup. Environ. Health. $39: 207-218$.

Weiser, P. C., et al. 1973. "Effects of Low-Level Carbon Monoxide Exposure on the Adaptation of Healthy Young Men to Aerobic Work at an Altitude of 1610 Meters." In Environmenta? Stress - Individual Human Adaptations. L. J. Folinsbee et al. (eds.), Academic Press, New York, New York. 
Wiley, H. W. 1980. "General Results of the Investigations Showing the Effect of Formaldehyde Upon Digestion and Health." Circular 42, U.S. Department of Agriculture, Bureau of Chemistry, Washington, D.C.

Wilson, C. 1984. "Mapping the Radon Risk of Our Environment." In Vol. 2 Indoor Air - Radon, Passive Smoking, Particulates and Housing Epidemiology. Swedish Councit for Building Research, Stockholm, Sweden.

Winneke, G. 1973. "Behavioral Effects of Methylene Chloride and Carbon Monoxide as Assessed by Sensory and Psychomotor Performance." In Behavioral Toxicology. Early Detection of Occupational Hazards. Proceedings of a Workshop, C. Xintaras et al. (eds.), HEW Publication No. (NIOSH) 74-126, U.S. Department of Health, Education and Welfare, Washington, D.C.

Wise, K. N. 1982. "Dose Conversion Factors for Radon Daughters in Underground and Open-Cut Mine Atmospheres." Health Phys.

Wright, E. S., and C. M. Couves. 1977. "Radiation-Induced Carcinoma of the Lung - the St. Lawrence Tragedy." J. Thorac. Cardiovasc. Surg. 74:495.

Wright, G., P. Randell and R. J. Shephard, 1973. "Carbon Monoxide and Driving Skilis." Arch. Environ. Health. 27:349-354. 
- 
PNL -6735

UC-95d

\section{DISTRIBUTION}

No. of

Copies

OFFSITE

10 DOE/Office of Scientific and Technical Information

2

J. Boulin

U.S. Dept. of Energy Forrestal Building, CE-131 1000 Independence Ave., SW Washington, DC 20585

J. Millhone

U.S. Dept. of Energy

Forrestal Building, CE-13

1000 Independence Ave., SH

Washington, DC 20585

J. Smith

U.S. Dept. of Energy

Forrestal Building, CE-131

1000 Independence Ave., SW

Washington, DC 20585

3 S. Walder

U.S. Dept. of Energy

Forrestal Building, CE-131

1000 Independence Ave., SW

Washington, DC 20585

T. Alereza

ADM Associates, Inc.

3299 Ramos Circle

Sacramento, CA 95827

J. Blair

DCA of Pennsylvania

Dept. of Community Affairs

Forum Building, Room 508

Harrisburg, PA 17120
No. of

Copies

OFFSITE (cont'.)

R. Busch

RD Busch and Associates

8209 Sprenger NE

Albuquerque, NM 87109

D. Conover

NCSBCS

481 Carlisle Drive

Herndon, VA 22070

R. Dixon

State of Florida

2740 Centerview Drive

Tallahassee, FL 32399

C. Gilbo

Charles F. Gilbo Consultant

201 E. Ross Street

Lancaster, PA 17602

L. Holder

LM Holder III Incorporated

$500 \mathrm{~N}$ Cap of TX Hwy

B1dg 3

Austin, TX 78746

Y. Huang

Lawrence Berkeley Laboratory

One Cyclotron Road

Building 90

Berkeley, CA 94720

M. Levy

The Levy Partnership

40 East 19th Street

7 th Floor

New York, NY 10003 
No, of

Copies

OFFSITE (cont'.)

F. McQuiston

Oklahoma State University

School of Mechanical Engr.

Stillwater, OK 74078

D. Nall

Jones, Nall \& Davis

57 Forsyth Street $\mathrm{NW}$

Suite 80

Atlanta, GA 30303

G. Raymond

Carrier Corporation

P.0. Box 4808

Syracuse, NY 13221

R. Ritschard

Lawrence Berkeley Laboratory

Building 90-3125

Berkeley, CA 94720

2 J. Rivera

O\&R International Ltd.

962 Wayne Avenue

Silver Spring, MO 20910

R. Tracey

Ryan Homes

100 Ryan Court

Pittsburgh, PA 15205

$H$. Trechsel

P.0. Box 211

Germantown, MD 20874-0211

J. Wright

ASHRAE

1791 Tullie Circle NE

Atlanta, GA 30329

\section{ONSITE}

DOE Richland Operations office

R. F. Christensen, A5-90
No. of

Copies

ONSITE (cont'.)

51 Pacific Northwest Laboratory

M. R. Brambley (10), K5-20

J. W. Callaway (5), K6-55

C. C. Conner, K5-20

D. B. Crawley, K5-20

C. A. Geffen, K6-55

O. L. Hadley (2), K5-20

R. E. Jarnagin, $k 5-20$

B. M. Johnson, K5-02

L. D. Kannberg, K5-20

A. D. Lee, K6-55

V. B. Lortz, K1-86

R. G. Lucas, K5-20

S. J. Marsh, K6-58

G. B. Parker, K5-20

R. G. Pratt, $k 5-20$

R. W. Reilly, K6-61

J. M. Roop, K6-58

T. J. Secrest, $K 5-20$

G. M. Stokes, K2-51

J. J. Tawi 1, K6-58

Z. T. Taylor (10), K5-20

J. J. Thomas, K1-86

Publishing Coordination

Technical Report Files (5), K5-20

Distr.2 